\title{
Acute buikpijn in de eerste en tweede lijn
}

Citation for published version (APA):

Krebber, T. F. W. A. (1988). Acute buikpijn in de eerste en tweede lijn. [Doctoral Thesis, Maastricht University]. Rijksuniversiteit Limburg. https://doi.org/10.26481/dis.19881125tk

Document status and date:

Published: 01/01/1988

DOI:

10.26481/dis.19881125tk

Document Version:

Publisher's PDF, also known as Version of record

\section{Please check the document version of this publication:}

- A submitted manuscript is the version of the article upon submission and before peer-review. There can be important differences between the submitted version and the official published version of record.

People interested in the research are advised to contact the author for the final version of the publication, or visit the DOI to the publisher's website.

- The final author version and the galley proof are versions of the publication after peer review.

- The final published version features the final layout of the paper including the volume, issue and page numbers.

Link to publication

\footnotetext{
General rights rights.

- You may freely distribute the URL identifying the publication in the public portal. please follow below link for the End User Agreement:

www.umlib.nl/taverne-license

Take down policy

If you believe that this document breaches copyright please contact us at:

repository@maastrichtuniversity.nl

providing details and we will investigate your claim.
}

Copyright and moral rights for the publications made accessible in the public portal are retained by the authors and/or other copyright owners and it is a condition of accessing publications that users recognise and abide by the legal requirements associated with these

- Users may download and print one copy of any publication from the public portal for the purpose of private study or research.

- You may not further distribute the material or use it for any profit-making activity or commercial gain

If the publication is distributed under the terms of Article $25 \mathrm{fa}$ of the Dutch Copyright Act, indicated by the "Taverne" license above, 


\section{ACUTE BUIKPIJN IN DE EERSTE EN TWEEDE LIJN}

Proefschrift

ter verkrijging van de graad van doctor

aan de Rijksuniversiteit Limburg te Maastricht,

op gezag van de Rector Magnificus, prof.dr. F.I.M. Bonke,

volgens het besluit van het College van Dekanen,

in het openbaar te verdedigen

op vrijdag 25 november 1988 om 16.00 uur

door

THEODORUS FRANCISCUS WILHELMUS ANTONIUS KREBBER geboren op 18 april 1946 te Tilburg 


\section{PROMOTORES:}

Prof.dr. W. Brouwer

Prof.dr. J.M. Greep

\section{BEOORDELINGSCOMMISSIE:}

Mr. F.T. de Dombal M.A., M.D., F.R.C.S.

Prof.dr. J.A. Flendrig

Prof.dr. J. de Haan

Prof.dr. J.A. Knottnerus

Dr. J.J. Petit 
Aan: Mijn ouders

Marianne

Willem

Dorine

Anne-Marie 
"Want zij die bijwoorbedd een proefschrift schrijwen, dat immers alleen bestemd is om aan het oordeel van enige professoren te worden onderworpen, en die de strengste en meest deskundige critici niet vrezen, zijn, dunkt me, meer te beklagen dan te benijden, daar ze zich eindeloos aftobben. Ze voegen toe, veranderen, schrappen, herstellen weer, herzien, werken het weer geheel en al om, laten het graag anderen zien, houden het. negen jaar in portefeuille en zijn nooit tevreden met het resultaat. De beloning, die ze er tenslotte woor krijgen -immers de lof yan cen enkeling - is wel heel duwr betald met al hun zwoegen, zweten en gebrek aan het zoetste, wat er bestaal: de slaap. Voeg hierbij nog dat dit alles gaat ten koste van hun gezondheid, dat ze daardoor humeurig, telijk, bijziende of zelfs' blind worden, tot armoede vervallen, bij ieder uit de gunst zijn, dat ze alle genoegens moeten verzaken, dat ze vóór hun tijd oud zijn, onuijdig sterven en wat dies meer zij.

Doch al deze opofferingen getroosten zij zich gaane om de goedkeuring weg te dragen wan én of twee geleerde boekenwurmen" ${ }^{\prime \prime} . .$.

Erasmus, 1509 
Hoofdstuk 1 DOEL VAN DE STUDIE

Hoofdstuk 2 HET PROBLEEM "ACUTE BUIK" 13

2.1 Omvang van het probleem 13

2.2 Het begrip "acute buik" 14

2.3 Aandoeningen die acute buikpijn kunnen veroorzaken 16

Hoofdstuk 3 HISTORISCHE BESCHOUWINGEN 21

3.1 Prehistorie-negentiende eeuw 21

3.2 Negentiende en twintigste eeuw 25

Hoofdstuk 4 TOPOGRAFIE DER BUIKORGANEN 31

4.1 Buikwand, peritoneum 31

4.2 Buikorganen 32

Hoofdstuk 5 (BUIK)PIJN

5.1 Begripsomschrijving 35

5.2 Oorzaak 36

5.3 Geleiding 36

5.4 Gewaarwording 38

5.5 Soorten buikpijn 38

5.5.1 Pariëtale of somatische buikpijn $\quad 38$

5.5.2 Viscerale builkpijn $\quad 39$

5.5.3 Gerefereerde piin 39

5.6 Hyperalgesie $\quad 40$

5.7 Irradiatie 40

5.8 Geprojecteerde pijn 40

Hoofdstuk 6 HET KLINISCHE BESLISSINGSPROCES 41

6.1 De diagnose als onderdeel van het klinische beslissingsproces 41

6.2 Klinisch spectrum 44

6.3 Snelle diagnostiek en de waarde van heronderzoek 45

Hoofdstuk 7 ONDERZOEKSMETHODE

$\begin{array}{lll}7.1 & \text { Soort verslaglegging } & 47\end{array}$

7.2 Participerendeartsen, regio Maastricht 48

7.3 Verloop van de Acute Buik Analyse 49

Hoofdstuk 8 PATIËNTENPOPULATIE

8.1 Inleiding 52

8.2 Stroom van onderzoekspopulatie 53 8.3 Verwijzing, zelfverwijzing, indeling van de
totale populatie in groepen 
8.4 Onderzoekende specialismen op de EHBO 57

8.5 Beleid EHBO 58

8.6 Follow-up na diagnostische beslissingen op de EHBO 60

8.7 Einddiagnoses, mortaliteit 61

8.8 Vergelijking einddiagnose met internationale bevindingen 63

8.9 Geslacht, leeftijd. 64

8.10 Groep A (zelfverwijzers) 67

8.11 Waarneming, spoed, consulten en visites 69

8.12 Discussie 71

8.12.1 Algemeen 71

8.12.2 Categorieën einddiagnoses 73

8.12.3 Groep A (zelfverwijzers) $\quad 75$

8.12.4 Waarneming, spoed, consulten en visites $\quad 76$

8.13 Conclusies en aanbevelingen betreffende doelstelling $1 \quad 77$

$\begin{array}{lll}\text { Hoofdstuk } 9 & \text { TIJDSVERLOOP } & 79\end{array}$

9.1 Inleiding 79

9.2 Tijdsverloop in de totale populatie (1100 casus) 81

9.3 Groep A (zelfverwijzers, 160 casus) 83

9.4 Groep C, Den E (door een huisarts verwezen, 909 casus) 85

9.5 Groep E (op afgesproken manier verwezen door huisarts, 564 casus) $\quad 87$

9.6 Tijdsverloop bij einddiagnoses Non Specific Abdominal Pain en appendicitis (Groep E) 90

9.7 Discussie 95

9.7.1 Totale onderzoekspopulatie 95

9.7.2 Groep A (zelfverwijzers) versus groep C,
Den E (door huisarts verwezen)

9.7.3 Groep E (op afgesproken manier door
huisarts verwezen)

9.7.4 Non Specific Abdominal Pain, appendicitis (einddiagnoses) 97

9.8 Conclusies en aanbevelingen betreffende doelstelling $2 \quad 99$

Hoofdstuk 10 WAARSCHIJNLIJKHEIDSDIAGNOSE EN EINDDIAGNOSE 101

10.1 Inleiding 101

10.2 Waarschijnlijkheidsdiagnose versus einddiagnose $\quad 103$

10.3 Conclusies en aanbevelingen betreffende doelstelling $3 \quad 107$ 
Hoofdstuk 11 ALGEMENE CONCLUSIES EN AANBEVELINGEN 109

SAMENVATTING 111

SUMMARY 115

LITERATUUR 119

BIJLAGEN 125

DANKWOORD 155

CURRICULUM VITAE 156 



\section{Hoofdstuk 1}

\section{DOEL VAN DE STUDIE}

Verhoudingsgewijs bestaat er een schaarste aan huisartsgeneeskundige literatuur over diagnostiek en beleid bij acute buikpijn. Studies over dit onderwerp werden, op een enkele uitzondering na (Gunn 1976), uitsluitend in de kliniek verricht. Het betrof in de meeste gevallen artikelen in de vorm van casuüstische mededelingen. De fase vóor het klinische onderzoek bleef op deze wijze buiten beschouwing.

Deze bevinding heeft geleid tot de in de volgende hoofdstukken beschreven studie die als doel heeft een wat duidelijker inzicht te geven in wat er met een patiënt met acute buikpijn gebeurt en wanneer. Op welk tijdstip begon de klacht, welke diagnoses werden er achtereenvolgens door de huisarts en later in het ziekenhuis gesteld, werd er wel of niet geopereerd, hoeveel tijd kostten de verschillende procedures enzovoort. Kortom: een explorerend en beschrijvend onderzoek naar de oorzaken van en de gebeurtenissen bij casus met acute buikpijn, vanaf het moment van ontstaan tot aan de oplossing van het diagnostische vraagstuk. Dit onderzoek wordt in het vervolg "Acute Buik Analyse" genoemd.

De doelstelling van de Acute Buik Analyse is drieledig.

1. Analyse van de patiëntenpopulatie en het verloop van de casus tot aan de einddiagnoses.

2. Tijdsanalyse van de verschillende fasen in het ziekteverloop tot aan ontslag of overlijden.

3. Analyse van de door de huisartsen en op de EHBO van het Academisch Ziekenhuis Maastricht gestelde waarschijnlijkheidsdiagnoses, getoetst aan elkaar en aan de einddiagnose.

Deze doelstellingen in aanmerking nemende kan gezegd worden dat in de Acute Buik Analyse eigenlijk een overzicht en een beschrijving wordt gegeven van diagnostiek en beleid bij een groot aantal casus met acute buikpijn. Het is niet uitgesloten dat, vooral wat het huisartsenbeleid betreft, de uitkomsten van de verschillende analyses meer nieuwe vragen oproepen dan ruimte bieden voor conclusies. Hopelijk zullen deze vragen dan resulteren in meer gericht vervolgonderzoek.

Buiten de werkplek zijn de meest belangrijke verschillen tussen de huisartsgeneeskunde en de klinische geneeskunde:

- de huisarts is "generalist": zijn handelen bestrijkt elk deelgebied van de geneeskunde;

- de huisartsgeneeskunde speelt zich in hoofdzaak af in een bepaald deel van het "klinisch spectrum" (zie paragraaf 6.2); in Nederland wordt 80 tot $90 \%$ van alle aan de gezondheidszorg aangeboden problemen geheel binnen de huisartsenpraktijk afgehandeld (Knottnerus, 1988);

- de huisarts heeft een "zeeffunctie", moet hij wel of niet verwijzen en wat is de aard van een eventuele verwijzing;

- de huisarts doet zijn werk vaak onder minder ideale omstandigheden (minder faciliteiten tot aanvullend onderzoek, minder mogelijkheden tot intercollegiaal consulteren en minder mogelijkheid tot adequate observatie van de patiënt).

Huisartsen en specialisten hebben een geheel eigen plaats en functie in het medische systeem. Zij vullen elkaar aan. Dit samenwerken in elkaars verlengde is de spil van de Nederlandse gezondheidszorg. 
In dit proefschrift komen een aantal zaken rond acute buikping aan de orde. De volgende synopsis geeft dit weer.

In hoofdstuk 2 wordt uitgelegd welke ornvang het probleem "acute buik" heef, hoe weinig onderzock er gedaan is naar de bildrage van de huisartsgeneeskunde aan de diagnostick en het beleid bil dit probleem, welk cen scala van definities er bestaat tern aanzien van het begrip "acute buik" en hoeveel aandoeningen acute buikpijn kunnen veroorzaken. In de Acute Buik Analyse zal bij woorkeur over "acute buikpiin" worden gesproken omdat het begrip "acute buik" te beladen is: het wekt ten onrechte de suggestie dat operatieve therapie bijna altijd noodzakelijk is. Het "acute" slaat in dit verband dan op de naar het oordeel van de arts bestaande noodzaak on zo snel mogelijk helderheid over de casus te krijgen en niet zozeer op een acuut begin van het ziektebeeld.

In hoofdstuk 3 wordt een overzicht gegeven van de speurtocht door de eeuwen heen naar de oorzaken van acute buikpijn. De geneeskunde van de verschillende volkeren en culturen wordt beschreven. De nadruk ligt op de enorme sprong voorwaarts, die de geneeskunde ten aanzien van de diagnostiek en behandeling van acute buikklachten heeft gemaakt gedurende de laatste honderd jaar.

Hoofdstuk 4 geeft aan dat optimale beoordeling van acute buikpijn niet mogelijk is zonder voldoende inzicht in de normale topografie van de buikorganen. Relevante literatuur wordt belicht. Hoewel dit hoofdstuk niet zozeer een basis vormt voor de beschrijving van de studie is het voor de volledigheid toch toegevoegd.

In hoofdstuk 5 wordt de fysiologie van de pijn in het algemeen, en van de buikpijn in het bijzonder beschreven. Buikpijn is het gemeenschappelijke hoofdkenmerk van alle in de Acute Buik Analyse bestudeerde casus. Eveneens wordt in dit hoofdstuk een opsomming gegeven van de verschillende soorten buikpijn. Onderkennen hiervan is voor de diagnostische procedure van grote betekenis. Ook dit hoofdstuk dient meer de volledigheid dan dat het een basis vormt voor de beschrijving van de studie.

In hoofdstuk 6 wordt aangegeven hoe de diagnostische beslissingsprocedure verloopt . Zonder adequate diagnose is het meestal niet mogelijk een behandeling te kiezen die de beste prognose heeft. Zonder een op degelijk onderzoek gefundeerd idee over de oorzaak of de ernst van het ziektebeeld is passend beleid niet te voeren.

Hoofdstuk 7 beschrifft de conceptie, opzet en uitvoering van de Acute Buik Analyse; het betreft een prospectieve studie die werd verricht gedurende negentien maanden, van 1-11-1982 tot 31-5-1984. Er werden 1100 casus bestudeerd waarvan de gegevens op special ontwikkelde formulieren zijn vastgelegd. 72 Huisartsen en de EHBO van het Academisch Ziekenhuis Maastricht werkten in totaal aan de Acute Buik Analyse mee. De huisartsen kregen als opdracht om bij alle patiënten met buikpijn die zij, ongeacht causa of duur ervan, met spoed naar het ziekenhuis verwezen, het onderzoeksformulier volledig in te vullen en dit met de patiënt in plaats van de gebruikelijke verwijsbrief mee te geven. 
Aan de EHBO werd de opdracht gegeven om een onderzoeksformulier volledig in te vullen bij ellke confrontatie met een patiënt met buikpijn, ongeacht causa of duur ervan en ongeacht het feit of de patiënt al dan niet door een huisarts verwezen was.

Hoofdstuk 8 beschrijft de patiëntenpopulatie en betreft de eerste doelstelling: analyse van de patiëntenpopulatie en het verloop van de casus tot aan de einddiagnoses. Er wordt een schematisch owerzicht gegeven van de samenstelling en het verloop van de patiëntenstroom en van de gestelde diagnoses. In de onderzochte populatie worden twee hoofdgroepen onderscheiden:

1) zij die door een huisarts direct werden verwezen;

2) zij die zich uit eigen beweging op de EHBO meldden.

In hoofdstuk 9 komt doelstelling 2 aan de orde: de tijdsanalyse van de verschillende fasen in het ziekteverloop tot aan ontslag of overlijden van de patiënt. De tiid wordt gemeten tussen verschillende cruciale momenten in het verloop van een casus: vanaf het begin van de klacht tot aan het moment dat medische hulp ingeroepen wordt, vanaf het moment van onderzoek tot aan het moment van opereren, enzovoort.

In hoofdstuk 10 wordt de derde doelstelling gerealiseerd: analyse van de gestelde diagnoses. De door de huisartsen en op de EHBO gestelde waarschijnlijkheidsdiagnoses worden onderling vergeleken en getoetst aan de einddiagnose. Tevens worden enkele diagnoses belicht die vaak onderling werden verwisseld.

In hoofdstuk 11 volgen de algemene conclusies. Ook worden aanbevelingen gedaan, vooral ten behoeve van eventueel vervolgonderzoek.

Tenslotte wordt, in de Nederlandse en in de Engelse taal, een samenvatting gegeven van de Acute Buik Analyse, gevolgd door het literatuuroverzicht, de bijlagen, het dankwoord en het curriculum vitae van de auteur van dit proefschrift. 


\section{Hoofdstuk 2}

\section{HET PROBLEEM "ACUTE BUIK"}

\subsection{Omvang van het probleem}

Het is bekend dat acute buikpijn een scala van oorzaken kan hebben, variërend van levensbedreigend (perforaties, obstructies) tot onschuldig (gastro-enteritis, ovulatiepijn). Ernstige aandoeningen zijn in aanvang soms symptoom-arm terwijl buikpijn, welke uiteindelijk van onschuldige aard bleek, dramatisch kan beginnen. Een klinisch beeld kan à la minute van karakter veranderen. Onbehandeld kan een acuut buikbeeld de dood tot gevolg hebben. Een aantal treffende casus zijn beschreven door Mondor (1950). Een juist en zo vroeg mogelijk gestart beleid daarentegen zal de grootste kans op volledige genezing bewerkstelligen (Cope 1979, De Dombal 1980).

Voor elke rechtgeaarde arts blijft het elke keer opnieuw een uitdaging om de symptomen en bevindingen bij acute buikpijn zodanig te ordenen en te interpreteren dat een zo adequaat mogelijke diagnose kan worden gesteld en op grond hiervan snel en effectief kan worden gehandeld.

Vrijwel iedere praktizerende arts kent, vaak uit eigen ondervinding, verhalen over zeer indrukwekkende gevallen van acute buikpijn met een al dan niet gelukkige afloop. Door de casuiistiek loopt de rode draad van de noodzaak om voortdurend alert te zijn, met als dreigend gevaar om soms toch voor onplezierige verrassingen te komen staan. Toch meent de praktiserend arts vaak, dit onderbouwend met een opsomming van een aantal door hem zeer juist gestelde diagnoses, dat hij of zij het over het algemeen wel klaarspeelt met acute buikklachten (De Dombal 1980).

In dit verband is het van belang te benadrukken dat de beste diagnost juist diegene is die over het geheel genomen de minste vergissingen maakt en zeker niet hij of zij, die bij toeval een min of meer briljante diagnose weet te stellen.

Geen enkele fout, gemaakt bij het diagnostiseren, blijkt origineel te zijn (Angell 1978). Recente onderzoekingen laten een niet al te rooskleurig beeld zien van het vermogen van artsen om te diagnostiseren en een slagvaardig therapeutisch beleid te voeren: uit een groots opgezer onderzoek onder leiding van de Britse chirurg De Dombal, in verscheidene landen gedurende een periode van tien jaar waarbij meer dan 10.000 gevallen van acute buikpiin werden bestudeerd, bleek dat in praktisch alle ziekenhuizen ongeveer de helft van het aantal gepresenteerde gevallen in eerste instantie verkeerd werd beoordeeld. Mede hierdoor kon het gebeuren dat meer dan een kwart, soms meer dan de helft, van het aantal acute appendicitiden reeds geperforeerd was of een abces had gevormd op het moment van opereren. Het aantal negatieve laparotomieën varieërde tussen de $20 \%$ en $80 \%$. Eén op de drie gevallen van maligniteit als oorzaak van de buikklachten werd niet als zodanig herkend en zelfs naar huis gestuurd (De Dombal 1980). In landen met het hoogste percentage negatieve laparotomieën (West-Duitsland, Oostenrijk) bleek de mortaliteit bij acute appendicitiden drie maal zo hoog te zijn als het Europese gemiddelde 
van 0,1\% (Lichtner en Pflantz 1971). De onderzoekers weten deze cijfers in hoofdzaak aan een, tijdens de medische opleiding geleerde, foure interpretatie van bevindingen. Ter illustratie enkele voorbeelden.

- Mc Burney heeft zijn beroemd geworden "punt" vastgesteld op grond van bevindingen bij slechts 11 patiënten. Waarschijnlijk door zijn grote persoonlijke owerwicht heeft deze chirurg zijn criterium weten te claimen als een "infallible and very exact guide to every case of appendicitis" (Mc Burney 1889).

- Van alle patiënten met buikpijn waarvoor achteraf geen afdoende verklaring werd gevonden had $29 \%$ piin in de rechter onderbuik tegen $74 \%$ van alle patiënten met een aangetoonde appendicitis acuta (Staniland 1972). Hoe vaak heeft piin in de rechter onderbuik ten onrechte de doorslag gegeven om wel operatief te behandelen?

- Slechts de helft van alle vrouwen met acute salpingitis geeft bij vaginaal toucher slingerpijn aan (De Dombal 1980). Hoe vaak is een negatieve bevinding verkeerd geïnterpreteerd en met welke gevolgen?

In tegenstelling tot onderzoek dat in de kliniek werd gedaan, is huisartsgeneeskundig onderzoek naar diagnostiek en therapie bij acute buikpijnen schaars. Gunn (1976) signaleert een gemiddeld percentage door de huisartsen bij verwijzing juist gestelde diagnoses $\operatorname{van} 26 \%$, maar meent desondanks dat de "decision making" goed geweest is omdat al deze patiënten naar zijn oordeel terecht verwezen werden. Blacklock (1976) vond een percentage door de huisartsen juist gestelde diagnoses van $49 \%$ bij de verwezen mannen en $30 \%$ bij de verwezen vrouwen. Slechts 10\% van alle aan de huisartsen gepresenteerde gevallen van acute buikpijn werd naar het ziekenhuis verwezen. Onderzoek naar de niet verwezen casus is in de literatuur niet aangetroffen.

In de Nederlandse situatie is huisartsgeneeskundig onderzoek naar acuut begonnen buikpijn nooit verricht. Wel is enig klinisch onderzoek gedaan dat uitmondde in casuistische mededelingen (De Koning Gans 1985, de Boer 1986, Verhagen 1987), en enkele artikelen van epidemiologisch-beschrijvende aard (Hoogendoorn 1987). Slechts in éen geval werd een speciaal onderzoek gedaan (Petit 1984, Medisch Proefschrift, uitsluitend over opgenomen patiënten handelend).

\subsection{Het begrip "acute buik"}

"Acute buik" is een zeer bekende term. Het heeft de schrille klank van alarm. Hoewel het begrip algemeen wordt toegepast is het toch niet meer dan een aanduiding van ernst, en zeker geén diagnose: het staat voor een scala van buikaandoeningen (Rogers 1978, Jordan 1980, Saegesser 1981).

De aanduiding "acute buik" is pas na de eerste wereldoorlog vanuit de Verenigde Staten in Europa overgenomen. In her "Zentralblatt für Chirurgie" verschijnt de term in 1925 als trefwoord in het register. Over de exacte oorsprong is niets met zekerheid te zeggen. Toen de chirurgie acute levensbedreigende buikaandoeningen met succes kon behandelen en snelle operatieve therapie bepalend bleek voor de prognose (maar ten koste ging van meer precieze diagnostiek), kwam er behoefte aan een dergelijk begrip. "Acute buik" bleek als verzamelnaam van acute buikaandoeningen, waarvan de aetiologie nog niet duidelijk was maar waarbij wel een operatie-indicatie bestond, zó bruikbaar dat deze term tot op de 
huidige dag nog wordt gehanteerd. Dick (1952) schreef het algemene gebruik in zijn tijd toe aan de kortheid, zinvolheid en algemene begrijpelijkheid van het begrip; niet in de laatste plaats omdat het constateren van deze conditie ziekenhuisopname en operatie meestal noodzakelijk maakte.

Het gebruik van de aanduiding "acute buik" is een gevolg van diagnostische ontoegankelijkheid: indien elke acute buikaandoening onmiddellijk naar oorzaak en locatie kon worden gediagnostiseerd was het begrip niet nodig (Dick 1952). Kern (1979) velt een waarde-oordeel over de diagnose "acute buik": hij spreekt van medische insufficiëntie.

Uit de literatuur blijkt dat bijna alle auteurs het erover eens zijn dat, hoewel een "acute buik" vele verschijnselen kan vertonen als shock, nausea enzovoort, pijn (spontaan en/of drukpijn), défènse musculaire en peristaltiekstoornissen min of meer hoofdsymptomen zijn. Dick (1952) meent zelfs dat, indien intensief genoeg, de aanwezigheid van een van deze drie hoofdsymptomen al voldoende is om te kunnen besluiten tot een "acute buik". Bij minder overtuigende symptomatologie is "Fingerspitzengefülnl" van de onderzoekende arts van doorslaggevende betekenis. Met andere woorden, de arts moet hierbij op zijn ervaring steunen.

Hoewel er een redelijke consensus bestaat over de symptomatologie, blijkt er van de term "acute buik" geen algemeen aanvaarde, duidelijke begripsomschrijving of definitie te zijn. De over dit onderwerp geraadpleegde auteurs hebben ofwel een geheel eigen begripsomschrijving of definitie ontwikkeld, ofwel komen in het geheel niet hiertoe, terwijl ze de term "acute buik" wel gebruiken (Mondor 1950, Harrison 1971, Angell 1978, Cope 1979). Om de veelheid aan definities en begripsomschrijvingen te demonstreren volgt hier een kleine bloemlezing:

- acute buik is een door tijdnood gedicteerde, voorlopige aanduiding van ziektegevallen tot aan hun diagnostische oplossing (Dick 1952);

- een grote verscheidenheid aan aandoeningen in de buikholte en retroperitoneale ruimte, waardoor opname in het ziekenhuis met spoed noodzakelijk en chirurgische therapie op korte termijn meestal vereist is; pijn is hierbij het meest voorkomende en belangrijkste symptoom (Muller en Henneman 1972);

- de acute buik vereist een acute beslissing (Moore, in Botsford's "The Acute Abdomen", 1977);

- medisch bargoens voor elke acute buikaandoening die onmiddellijk operatief ingrijpen noodzakelijk makkt (Dorlands Medical Dictionary, Rogers 1978);

- vergelijkbaar met "acute buik" is de aandoening "zware ongevalsverwonding" waarmee de patiënt opgenomen moet worden en die tot onmiddellijk handelen kan dwingen, maar die tegelijkertijd een gedifferentieerde en heldere diagnosestelling vergt (Kern 1979);

- het probleem "acute buik" houdt in de presentatie van een patiënt aan zijn of haar arts met een anamnese van tot dusverre onopgehelderde buikpijn, die korter dan een week bestaat. (De Dombal 1980);

- acute buik is geen diagnose maar een absolute noodzaak om een diagnose te stellen (Kaess 1980); 
- acute buik is een uitdrukking, gebruikt om veel verschillende soorten abdominale condities aan te geven waarvan de symptomen kunnen variëren van een levensbedreigende gastro-intestinalle bloeding tot een milde dyspepsie (Janzon 1982).

Soms worden, in navolging van Herman Boerhaave (1709), aforismen gebruikt die tot doel hebben de lezer, door de bondigheid en simpelheid ervan, in te scherpen dat snel operatief handelen van veel groter belang is dan tijdrovende pogingen om een zo zeker mogelijke diagnose te stellen: "in dubio, pro operatione" (Dick 1952), of "beter een slecht chirurg dan een te late operatie" (Muller en Henneman 1972), of "better to be safe than to be sorry" (Cope 1979), of "if in doubt, cut it out, it is far safer to open than to await the development of gangrene" (Perdikes 1982).

Hoofdkenmerk van al deze definities, omschrijvingen en aforismen is het ontbreken van een adequate diagnose en het aanwezig zijn van de noodzaak tot opname en snelle (chirurgische) oplossing van het probleem.

Hoewel algemeen bekend en gebruikt wordt de term "acute buik". in deze studie met grote terughoudendheid gehanteerd. Immers, toepassing ervan suggereert de aanwezigheid van ernstige buikpathologie en de noodzaak tot snel chirurgisch ingrijpen. Maar verreweg de meeste als "acute buik" geètiketteerde casus worden in het geheel niet geopereerd (De Dombal 1980). Bij voorkeur zal dan ook gebruik worden gemaakt van de term "acute buikpijn". Het acute slaat in dit verband dan op de naar het oordeel van de arts bestaande noodzaak om zo snel mogelijk helderheid over de casus te krijgen, en niet zozeer op een acuut begin van het zicktebeeld.

\subsection{Aandoeningen die acute buikpijn kunnen veroorzaken.}

Indelingen naar diagnose zijn er in de literatuur legio (Rogers 1978, Saegesser 1981 en vele anderen). Soms wordt er onderscheid gemaakt op grond van wel en niet te opereren aandoeningen (Rogers 1978), in "echte" en "imitatie" acute buiken. Meestal vindt indeling plaats op grond van causa en/of locatie. Vanwege haar volledigheid en duidelijkheid, is gekozen voor de indeling naar Saegesser (tabel 2.1):

Tabel 2.1

Indeling oorzaken van acute buikpijn. (Sacgesser 1981).

Oorzaken van acute buikpijn

\section{BUIK}

\section{A. Buikwand}

Trauma, contusie, of niet penetrerende wond.

Haematoom door contusie (ruptuur van de arteria epigastrica), spontaan haematoom bij gebruik van anticoagulantia of bij stollingsstoornissen.

B. Open of gesloten trauma. Vaak multitraumatisch $\rightarrow$ peritonitis, hemoperitoneum of beide. 
Trauma van de buikholte met plotseling sterk verhoogde intra-abdominale druk $\rightarrow$ ruptuur van het diafragma ( $90 \%$ linker koepel)

N.B. Alle penetrerende of perforerende wonden beneden het niveau van de $4 \mathrm{e}$ intercostaalruimte vereisen een onderzoek naar eventuele intra-abdominale schade: het diafragma bij jonge personen en bij dyspnoische patiënten reikt bij diepe expiratie tot dit niveau.

\section{Prikkeling van het peritoneum.}

1. Chemisch: bloed, gal, urine (relatief weinig prikkelend), maaginhoud, pancreassap, inhoud van gebarsten cystes.

2. Bacteriële infectie: abcessen, acute cholecystitis, diverticulitis Meckeli, appendicitis, diverticulitis, pelviperitonitis, salpingitis, pyosalpinx, peritonitis ten gevolge van gynaecologische aandoeningen, toxisch megacolon van verschillende origine (ulceratieve colitis, Morbus Crohn, ischaemische colitis, amoebe-colitis, intestinale manifestaties van het syndroom van Behcet enz.), pseudomembraneuze enterocolitis, bacteriële necrotiserende enterocolitis, primaire pseudomembraneuze enterocolitis, primaire peritionitis (gram-negatieve bacteriën), acute lymphadenitis.

\section{Perforatie/ruptuur van een hol orgaan.}

Spontane oesophagus-ruptuur (syndroom van Boerhaave) ten gevolge van heftig braken.

Perforatie van maag en duodenum (ulcera, maligniteit, excessieve insufflatie tijdens narcose).

Perforatie van de galblaas.

Perforatie en ruptuur van de dunne darm.

Perforatie van divertikels in de dunne darm (jejunum).

Perforatie van de darm ten gevolge van typhus.

Perforatie van een Meckel's divertikel of perforatie aan de hals van een Meckel's divertikel welke ectopisch maagslijmvlies bevat.

Geperforeerde appendix of perforatie van een appendiculair unfiltraat naar de buikholte toe.

Perforatie van het colon door diverse oorzaken, ruptuur van een pathologisch gedilateerd caecum.

Perforatie van een toxisch megacolon.

Perforatie van het sigmoid, secundair aan diverticulitis.

Perforatie als gevolg van een segmentale gangreneuze necrose van colon of rectum.

Perforatie bij maligniteit.

Ruptuur van een pyosalpinx.

Uterusruptuur.

Perforatie van de galblaas.

\section{E. Ruptuur van een solide orgaan.}

Lever: trauma, maligne en (vooral) benigne tumoren, ruptuur van een levercyste. Milt: traumatische ruptuur, spontane ruptuur (normale milt?) of tijdens een bloedziekte (mononucleosis), malaria, Kala azar.

Extra-uterine graviditeit (soms tubair-abortus). 
Ruptuur van een ovariaalcyste (corpus luteum).

Ruptuur van een Graafse follikel (middenpijn).

F. Torsie van organen.

Volvolus van de maag (met hernia diaphragmatica).

Volvulus van de galblaas.

Volvulus van de dunne darm, caecum of colon sigmoideum.

Volvulus van een adnex.

Torsie van een ovariaalcyste.

G. Obstructie van een hol orgaan.

Acute dilatatie van de maag.

Obstructie van de dunne darm (ileus), paralytisch, mechanisch of ten gevolge van

strangulatie (hernia incarcerata, volvulus, intussusceptie, adhesies).

Urolithiasis.

Afsluiting van de galwegen door een steen (infundibulum van de galblaas of de ductus choledochus).

\section{H. Vasculaire origine.}

Ruptuur van de aorta abdominalis ten gevolge van een aneurysma.

Ruptuur van een aneurysma dissecans van de thoracale aorta, welke zich uitbreidt tot de aorta abdominalis.

Ruptuur van aneurysmata van de buikarterieën.

Nier- en miltinfarcten.

Kleine infarcten van dunne darm en colon met vasculitis (polyarteriitis nodosa, Morbus Bürger, collagenose, dermatomyositis, systemische lupus erythematosus, syndroom van Ehlers-Danlos enzovoort).

Hereditair angioneurotisch oedeem.

Purpura van Henoch-Schönlein.

Post-traumatische retroperitoneale of spontane (anticoagulantia) bloeding.

Intramurale hematomen in duodenum of jejunum.

Mesenteriaalinfarct met massieve necrose.

Verschillende soorten ischaemische colitis (segmentale necrose van het colon of rectum).

\section{THORAX}

Traumatische ruptuur van het diafragma en verdringing van de abdominale organen naar de thoracale holte (komt voor bij ernstige compressie van het bekken).

Pleuritis, pneumonie waarbij de pleura rustend tegen het diafragma betrokken is, vooral rechtszijdig en bij jonge patiënten.

Pneumothorax

Spontane ruptuur van de oesophagus (syndroom van Boerhaave) na ernstig braken.

Torsie van de maag bij een hernia diaphragmatica.

Myocardinfarct. 
Longembolie.

Klepgebreken (mitralisstenosis).

Aneurysma dissecans van de thoracale aorta.

Atherosclerose van de thoracale aorta welke leidt tot micro-embolieën in de mesenteriaalvaten.

\section{WERVELKOLOM}

Radiculitis (herpes zoster), compressie-fractuur, tumoren.

Peri-vertebraal hematoom na fractuur, compressie van het autonome zenuwstelsel met als gevolg paralytische ileus en distensie van de ingewanden.

\section{ALGEMENE OORZAKEN (METABOOL)}

1. Exogeen:

Beet van de tarantula.

Loodintoxicatie.

2. Endogeen:

Uraemie.

Dreigend diabetisch coma.

Porphyrie.

Familiaire hyperlipidaemie.

Allergische syndromen.

Hereditair angioneurotisch oedeem.

Regelmatig terugkerende peritonitis (familiaire paroxysmale polyserositis).

Hyperparathyreoidie (stofwisselingsstoornissen, pancreatitis).

MEA IIB syndroom (ganglioneuromatosis van de wand van de tractus digestivus met ileus en bloedingen).

Sommige hemolytische anemieën.

Bijnierschorsinsufficiëntie.

\section{NEUROPSYCHIATRISCHE ORIGINE}

Tabes dorsalis (tabetische crisis), herpes zoster, buikmigraine, psychogeen.

Uit deze grote hoeveelheid aandoeningen met ieder hun eigen, vaak weinig specifieke of elkaar overlappende symptomatologie (De Dombal, 1980) wordt duidelijk, dat het stellen van een juiste diagnose een complexe zaak kan zijn met een hoge graad van moeilijkheid. In hoofdstuk 10 wordt hierop teruggekomen. 



\title{
Hoofdstuk 3
}

\section{HISTORISCHE BESCHOUWINGEN}

\author{
"De geneeskunde is zo oud ats bet \\ geslacht der menser, de nood- \\ zakelijkheid deed de mensen \\ geneestkunde zoken en \\ vinden" Hippokrates, Prisca \\ Medicina, 350 v. Chr.).
}

\subsection{Prehistorie-negentiende eeuw}

Acute buikpijn moet de mens sinds onheuglijke tijden hebben beziggehouden. Het plotselinge begin, de vaak onduldbare pijn en een fatale afloop moeten zeer tot de verbeelding hebben gesproken en tot veel theorieën en behandelingswijzen hebben geleid. De vroegste theorieën waren die welke de ziekten beschouwden als een gevolg van de toorn der goden. Men probeerde hen op allerlei manieren tot erbarmen te bewegen. Het is dan ook niet vreemd dat de eersten die zich met geneeskunde bezig hielden priester waren. Hoewel in de loop der millenia veel geschreven en geëxperimenteerd is met betrekking tot acute buikklachten is van diagnostiek als basis voor succesvolle therapie pas sprake sinds krap honderd jaar!

Over de Indische geneeskunde tot ongeveer $1000 \mathrm{v}$. Chr. bestaat slechts een met fabelen vermengde overlevering. Susruta ( $500 \mathrm{v} . \mathrm{Chr}$ ) schreef de "Agur Veda", waarin laparotomieën, met als indicatie afsluiting van de darm, en operatieve verwijdering van blaasstenen uitvoerig worden beschreven. De toegepaste operatie-technieken zijn qua niveau te vergelijken met die in het Europa aan het einde van de zestiende eeuw. Anatomisch onderzoek was om religieuze redenen verboden.

Vooral door toedoen van Alexander de Grote heeft er een intensieve uitwisseling van kennis plaatsgevonden tussen Indiërs en Grieken.

De oude Egyptenaren geloofden dat de geneeskunst in oorsprong een geschenk was van Isis, godin der natuur en van haar zoon Horus.

Thot, god der kunsten en wetenschappen, werd als vader der geneeskunde vereerd. Hij legde de hele omvang van de Egyptische kennis vast in 42 papyrussen, waarvan er zes handelden over de geneeskunst. Een aantal is bewaard gebleven en werd bekend als de papyrus Ebers en de papyrus Edwin Smith, naar hun ontdekkers. Ze dateren uit $1500 \mathrm{v}$. Chr. en beschrijven onder meer nauwgezet de ligging der buikorganen en het onderzoek van de buik door middel van inspectie, palpatie en ausculatie. Zelfs onderzoek van urine en faeces als behorend bij her buikonderzoek wordt vermeld.

Ook uit andere documenten blijkt dat de Egyptenaren een gedetailleerde kennis bezaten over de anatomie van de buikorganen. Of deze kennis tijdens het balsemen der doden werd opgedaan is nier duidelijk.

De Egyptische gezondheidszorg kende algemene artsen en orgaanspecialisten (Herodotos, Historiae), een beetje te vergelijken met onze huisartsen en specialisten. 
Ook in de Griekse wereld werd de geneeskunde als een godsgeschenk beschouwd. De belangrijkste genezende god was Asklepios.

De eerste en beslissende stap in het losmaken van de geneeskunde van de natuurfilosofie en haar te verheffen tot zelfstandige wetenschap werd gezet door Hippokrates (460-375 v. Chr). Zijn geschriften markeren het begin van de Westerse geneeskunde. Zijn verzamelde werk staat bekend als het "Corpus Hippocraticum". Hierin wordt het buikonderzoek, bestaande uit inspectie, auscultatie, percussie en palpatie nauwkeurig beschreven.

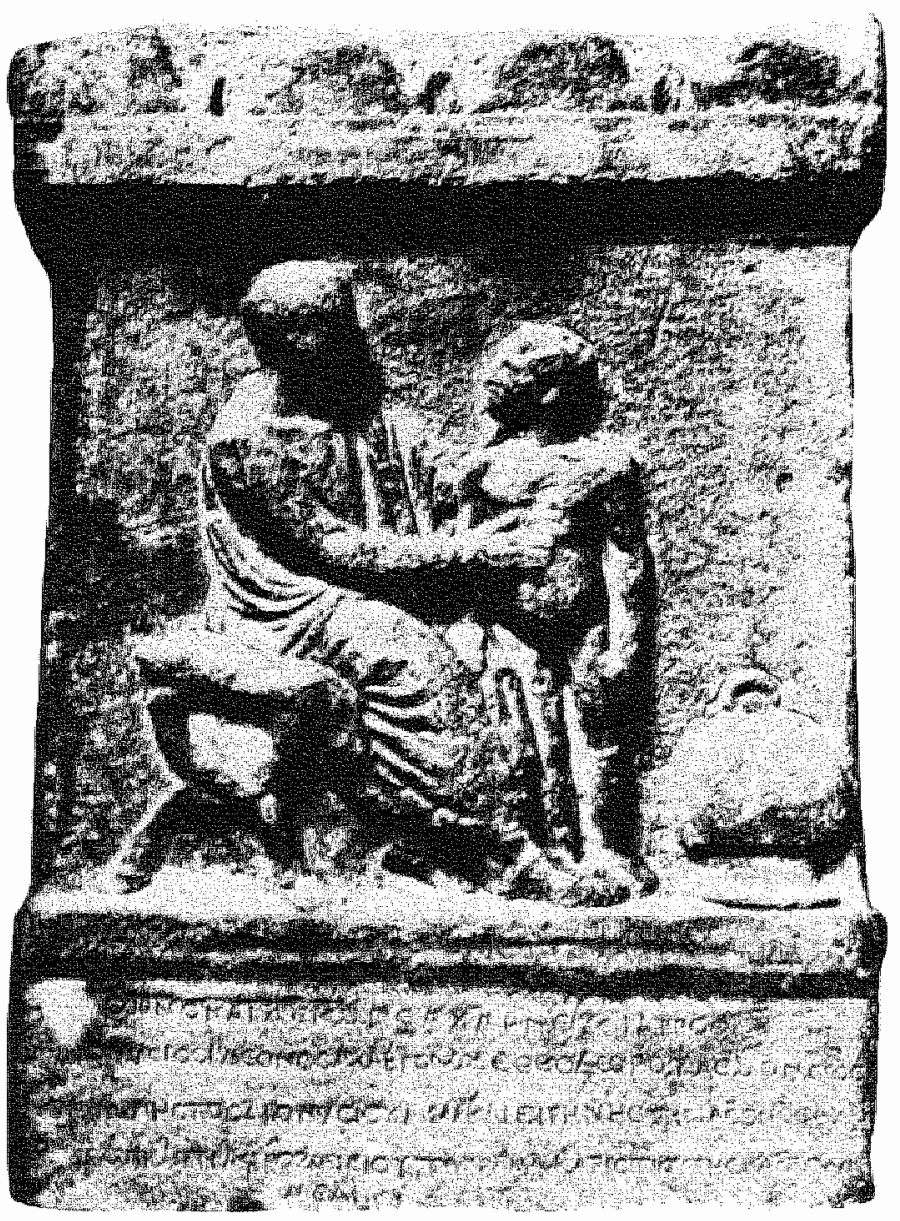

Figuar 3.1

De Griekse arts Iason palpeert de lewer bij een patiènt. Rechts beneden een zogenaamde (laat)kop om plaatselijk bloed te ontrrekken. (Bron: Prof.dr. G.A. Lindeboom; Inleiding tot de geschiedenis der geneeskunde; 1981)

Aan de hand van casuistiek worden algemene en locale symptomen bij buikziekten beschreven (facies Hippocratica, snelle pols, febris continua en intermittens, het kloppen van ontstekingen enzovoort). De beschrijving van het klinisch beeld bij acute darmafslui- 
tingen en ontstekingen in de buikholte vertoont grote overeenkomst met onze huidige opvattingen.

Praxagoras van $\mathrm{Kos}(350 \mathrm{v} . \mathrm{Chr}$.) stond erg agressieve therapieën voor zoals het geven van emetica en laxantia bij faecaal braken en bij uitblijvend resultaat, het openen van buik en darmen.

Herophiles, leerling van Praxagoras, wordt beschouwd als de grondlegger van de menselijke anatomie. Hij onderscheidde arteriën en venen en zelfs motorische en sensibele zenuwen. Hij heeft de naam gegeven aan het duodenun.

Een andere belangrijke anatoom was Erasistratos. Hij bestudeerde de fijnere bouw van lever en galwegen.

De geneeskunde volgens Griekse traditie beleefde haar bloei in Alexandrië tijdens de eerste eeuw voor Christus. Anatomisch onderzoek werd hier zelfs op veroordeelde (levende!) misdadigers gedaan. Ingrepen als paracentese van de buikholte en vergruizen van galstenen zouden met succes zijn verricht.

$\mathrm{Na}$ de verovering van Egypte door Augustus in 30 v. Chr. verplaatste het centrum van de geneeskunde zich naar het Romeinse Rijk, naar Rome.

De eerste Romeinse arts van betekenis was Aulus Cornelius Celsus (25 v. Chr.- 50 na Chr.). Zijn kennis is opgetekend in een groot encyclopedisch boekwerk: "De Artibus". Hierin is voor het eerst défènse musculaire beschreven als symptoom van ontstekingen in de buikholte. Ook werd uitgebreid aandacht besteed aan de verschijnselen bij afsluiting van de dunne en de dikke darm. De door Celsus aangegeven techniek van de steensnede heeft tot in de nieuwe tijd navolging gevonden.

Claudius Galenus (131-200), lijfarts van verschillende Romeinse keizers, heeft baanbrekend werk gedaan op het terrein van de ontleedkunde en de experimentele fysiologie. Zijn kennis heeft hij opgedaan tijdens studie op dieren (sectie op mensen was bij de wet verboden) en later samengevat tot éen systeem. Het systeem bestond uit drie delen: het aderlijke stelsel, het slagaderlijke stelsel en het zenuwstelsel. Deze visie heeft tot aan het einde van de zestiende eeuw de medische wetenschap beheerst.

Na de ondergang van het West-Romeinse Rijk verviel de westerse geneeskunde tot een primitieve staat. Deze situatie handhaafde zich ongeveer duizend jaar. De min of meer geschoolde artsen waren allen monnik (vooral Benediktijn). De chirurgie was hun echter verboden en kwam vooral in handen van barbiers.

In de late middeleeuwen kwam er langzamerhand verandering in deze situatie. Er werden medische scholen opgericht waar voor het eerst sinds de val van het Romeinse Rijk weer aanschouwelijk onderwijs werd gegeven.

De eerste sectie op een mensenlijk werd verricht in 1281 te Bologna. In dezelfde plaats werd in 1316 het eerste anatomische leerboek geschreven door Mondino de Luzzi.

Tijdens de tweede helft van de veertiende eeuw trad er in Europa een enorme cultuurverschuiving op. Hiermee werd ingeluid de periode die we de Renaissance (wedergeboorte van de verloren gewaande antieke cultuur) noemen (1300-1600). Anatomisch onderzoek nam een grote vlucht. Als grondlegger van de anatomie wordt beschouwd Andreas 
Vesalius (1524-1564). In 1543 schreef hij zijn "De Humani Corporis Fabrica Libri Septem", dat de basis vormt voor de moderne morfologie.

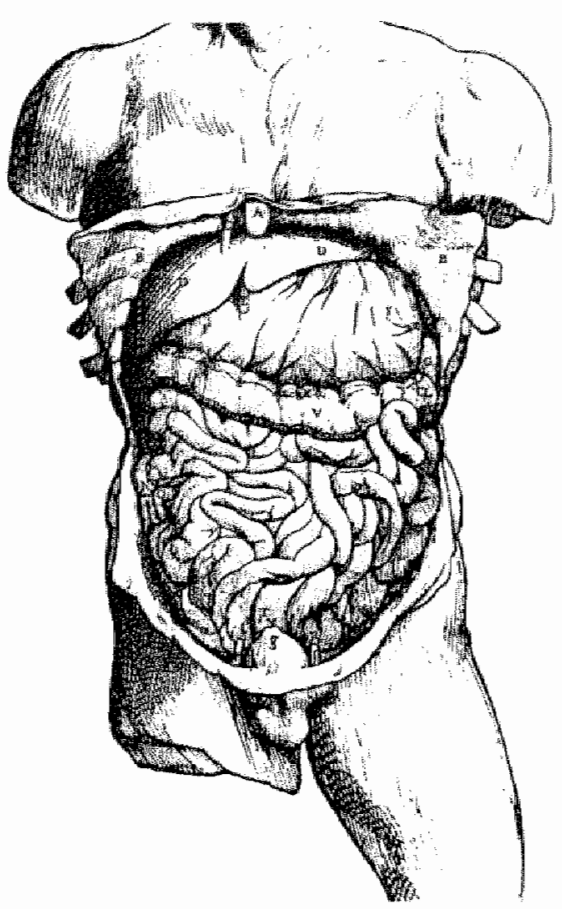

Figuna 3.2

Ligging van de buikorganen door VESALIUS. Illustratie uit: Andreas Vesallus (1543), De Humani Corporis Fabrica, Basel.

Houtdruk waarschijnlijk door Johannes Stephanus van Calcar.

(Bron: Dr. M.A. Verschuyl; Met naald en draad, van mier tot niet; 1988).

Naarmate de middeleeuwse denkwereld haar invloed verloor, taande de belangstelling voor de godsdienst en nam die voor de natuurwetenschappen toe. Het rationalisme deed zijn intrede onder invloed van de Verlichting. De ontdekking van de bloedsomloop door Harvey (1628) en de ontwikkeling van de fysiologie in de $17 \mathrm{e}$ eeuw leidden tot de "anatomica animata", de levende ontleedkunde of de fysiologie als aparte wetenschap.

Belangrijke Nederlanders in de ontwikkeling der anatomie waren Frederik Ruysch (1638-1731) en Antonie van Leeuwenhoek (1632-1723), de ontdekker van de mikroskoop. Ruysch was lektor in de anatomie aan de universiteit van Amsterdam en werd beroemd door zijn anatomische collecties. Een deel van de verzameling is door Czaar Peter de Grote gekocht en bevindt zich nog steeds in St. Petersburg. Ruysch had een prepareertechniek ontwikkeld waarbij hij gekleurde stollende vloeistoffen in de bloedvaten spoot waardoor hun fijnere verloop duidelijker zichtbaar werd.

Herman Boerhaave (1668-1738) was een systematicus die de gehele geneeskunde in één slluitend geheel wilde onderbrengen. Zijn invloed strekte zich over de hele toenmalige wereld uit tot in Amerika toe. 
Groeiende belangstelling voor de pathologische anatomie is een ander kenmerk van de geneeskunde in de achttiende eeuw, dat tot belangrijke resultaten leidde. Baanbrekend in dit opzicht is het boek van Giovanni Batista Morgagni geweest: "De sedibus et causis morborum per anatomen indagatis" (1761), dat geldt als een van de belangrijkste werken uit de geschiedenis der geneeskunde. In dit boek heeft Morgagni door de ziekelijke verschijnselen te relateren aan obductiebevindingen, aan de pathologische anatomie het karakter van "rariteit" ontnomen dat zij tot dusver had bezeten en haar aan de geneeskundige praktijk ten grondslag gelegd.

William Cheselden (1668-1752) verwierf internationale reputatie door zijn methode van steenverwijdering uit de blaas, waarbij hij de operatieduur terugbracht van een uur naar een minuut en waarbij de mortaliteit daalde van vijftig tot onder de tien procent. Pas in 1885 raakte zijn methode in onbruik toen men overging op lithotripsie.

Het begrip peritonitis werd in 1776 geintroduceerd door William Cullen in zijn "First lines of the practice of physic". Hij veronderstelde dat een ontsteking van het buikwlies uit zou kunnen gaan van intra-abdominale organen en gebruikte de termen gastritis en enteritis. Christopher Robert Pemberton echter was de eerste die in 1806 de symptomen van peritonitis beschreef als constante pijn, toenemende polsfrequentie, drukpijn, opgeheven ademexcursies en beslagen tong. Vreemd genoeg noemde hij niet het braken als symptoom. Op grond van deze symptomen onderscheidde hij peritonitis van kolieken. Hij heeft een definitieve stap voorwaarts gezet op de weg van de diagnostiek van de acute buik (Cope 1965).

John Hunter (1728-1793) kan als grondlegger beschouwd worden van de experimentele chirurgie. "Why think, why not try the experiment?"

De eerste mijlpaal in de historie der appendicitis is de publicatie van een obductie-verslag door de Duitse chirurg Lorenz Heister (1718). Hij beschreef een gangreneus ontstoken appendix en wees op de relatie tussen een brandende pijn ter plekke van de ligging van de appendix en een ontsteking hiervan. $\mathrm{Al}$ in 1736 werd de eerste succesvolle appendectomie verricht door de Engelse chirurg Claudius Amyand. Hij opereerde een elfjarige jongen aan een scrotaal breuk waarboven zich een fistel had gevormd. In de breukzak bevond zich naast omentum een ontstoken appendix, geperforeerd door een speld en tot een steenachtige massa geincrusteerd. Na verwijdering van het geheel kwam de fistel tot rust en genas de patiënt voorspoedig. Amyand wees in zijn operatieverslag vol trots op de lange duur en de hoge moeilijkheidsgraad van de ingreep en prees de jonge patiënt om zijn moed!

De idealen van de Verlichting zijn niet zonder invloed gebleven op andere belangstellingssferen in de geneeskunde. Men kreeg oog voor hygiënische wantoestanden aan boord van schepen, in gevangenissen enzovoort. Tal van ziekenhuizen werden gesticht.

\subsection{Negentiende en twintigste eeuw}

Gedurende de eerste decennia van de negentiende eeuw waren de ontwikkelingen in de geneeskunde gering. Op het fundament van anatomie en fysiologie, gelegd in vorige 
eeuwen, begon langzamerhand begrip te ontstaan omtrent de werkelijke oorzaken van ziekteprocessen. Symptomen, opgemerkt tijdens het ziekteverloop, werden gerelateerd aan post-mortem bevindingen en kregen een zekere objectieve betekenis. Systemarisch onderzock en medische verslaglegging kregen langzamerhand gestalte en werden stelselmatig verbeterd. Laennec ontwikkelde de stethoscoop in 1819 en beschreef de mogelijkheden ervan; de moderne koortsthermometer kwam in gebruik in 1867 terwijl de percussie als waardevolle onderzoeksmethode werd geïntroduceerd door de Weense arts Auenbrugger.

Op deze vindingen werd door anderen voortgebouwd, methoden werden gestroomlijnd en vervolmaakt: de geneeskunde kreeg hoe langer hoe meer een wetenschappelijk karakter.

De eerste onderbinding van een bloedend aneurysma van de aorta abdominalis werd verricht door de Engelse chirurg Sir Astley Paston Cooper in 1817. De ernstige bloeding werd gestelpt maar de onthouding van de onderste extremiteiten van bloed werd de patiênt na veertig uur moodlottig. Cooper gebruikte als eerste kattedarm als hechtmateriaal. Echt succesvol opereren van een buikaneurysma werd pas een eeuw later mogelijk.

Adequate verdoving was in de eerste helft van de negentiende eeuw niet mogelijk. De enig mogelijke pijnstilling bestond uit het pre-operatief toedienen van excessieve hoeveelheden brandewijn, het gebruik van verdovende kruiden of plantenextracten (opium) of het simpelweg toepassen van geweld! Uit de meeste operatieverslagen van die jaren bleek dat deze methoden bijzonder ondoeltreffend waren. Meer uitgebreide operaties konden alleen al door de pijn en de daarbij behorende emoties niet worden uitgevoerd. Er moest altijd snel worden gewerkt bij onrustige patiënten.

De geschiedenis van de inhalatie-anaesthesie begint in 1799, toen Sir Humphry Davy het lachgas introduceerde. Hem was opgevallen dat mensen onder invloed van dit gas begonnen te lachen en gekke dingen gingen doen. Al gauw werd lachgas als kermisattractie gebruikt. Tevens was het Davy opgevallen dat bij inhalatie ervan zijn hoofdpijn verdween en dat de pijn bij het trekken van een verstandskies erdoor verminderde. In 1800 suggereerde hii dat toepassing zinvol was bij operaties. Zijn advies werd niet opgevolgd, mogelijk omdat hij geen arts was.

De aether-anaesthesie werd in 1842 voor het eerst toegepast door de Amerikaan Crawford Long. Hij excideerde zonder overlast voor de patiënt een kleine halstumor.

William Thomas Green Morton introduceerde anaesthesie door aether in de tandheelkundige praktijk. Toen het mogelijk bleek om zonder pijn een been te amputeren kwam de grote doorbraak.

Tegen het midden van de negentiende eeuw was de pijn van de operatietafel gebannen maar een groot gevaar bleef de operatie-patiënt bedreigen: wondinfectie en sepsis. De toenmalige opvatting was dat er spontaan in de wond "iets" ontstond dat verantwoordelijk was voor infectie, dit naar analogie van de theorie van Aristotoles: de zogenaamde "generatio spontanea". Met deze voorstelling van zaken werd afgerekend door Louis Pasteur (1822-1895). Hij toonde aan dat micro-organismen niet spontaan in de substantie ontstaan maar van buitenaf daarin terechtkomen. 
De toepassing van het werk van Pasteur in de chirurgische praktijk is de verdienste geweest van de Engelse chirurg Joseph Lister (1827-1912). In zijn tijd overleed de helft van alle operatie-patiënten aan de gevolgen van een septische shock. Na de toename van het aantal en de aard van de operaties door doeltreffende anaesthesie rond 1860 steeg de mortaliteit dramatisch. Het werd een understatement dat een operatie-patiënt meer kans op overlijden had dan een soldaat op het slagveld bij Waterloo!

Lister startte een onderzoek naar de oorzaken van wondinfectie. Hij vermoedde dat de oorzaak hiervoor was aan te wijzen in zwevende deelrjes, die tijdens de operatie in de wond terechtkwamen. Hij trachtte dit te voorkomen door de lucht boven het operatieterrein te bevochtigen met carbol en na de ingreep de wond af te sluiten met in carbolzuur bevochtigd verband waarbij dan tevens de ziektekiemen chemisch vernietigd werden. De resultaten waren overtuigend. Zoals wel vaker gebeurt kreeg zijn methode het eerst navolging in het buitenland. Vooral Von Volkmann, hoogleraar chirurgie aan de universiteit van Halle, waar gangreen zo vaak voorkwam dat er werd gezegd dat daar niemand meer een mes durfde aan te raken, heeft de principes van Lister bijzonder vérgaand in de praktijk gebracht: "als vuil onvermijdelijk is, laat het dan antiseptisch vuil zijn".

Het percentage gangreen, pyaemie en erysipelas daalde van tachtig naar enkele procenten. In 1881 werd door Ogston een van de ergste verwekkers van wondinfectie, de staphylococcus aureus, ontdekt.

Von Bergmann introduceerde in 1886 de sterilisatie door stoom van operatiekledij en handdoeken. In hetzelfde jaar verplichtte Gustav Neuber uit Kiel zijn medewerkers tot het dragen van gesteriliseerde operatiekleding, het rituele wassen van de handen, het desinfecteren van de huid van de patiënt, het steriliseren van instrumenten, het irrigeren van de operatiewond met een zwakke oplossing van mercurochroom en de toepassing van steriel verband.

De eerste die onderkende dat ziekteverwekkers ook via vuile handen en instrumenten de wond konden infecteren was Semmelweis, die zijn studenten dan ook opdroeg om eerst de handen te wassen na terugkeer uit de snijzaal alvorens een bevalling te gaan doen! De "antisepsis" van Lister, later gevolgd door een systeem van "asepsis" (waarbij men tracht bacteriën uit de wond te houden door alles wat met die wond in aanraking komt kiemvrij te houden) hebben het voor de heelkundige vakken mogelijk gemaakt zich in een zeer snel tempo te ontwikkelen, na 2000 jaar op ongeveer hetzelfde niveau te hebben gestaan.

De invoering van antisepsis en anaesthesie heeft het mogelijk gemaakt lange en ingewikkelde operaties uit te voeren. Als eerste onder de grondleggers van de moderne buikchirurgie is te noemen Theodor Billroth uit Wenen. In 1872 reseceerde hij de oesophagus, in 1878 gedeelten van de darm en in 1881 de pars pylorica van de maag.

Zijn leerling, Anton Woelfler, introduceerde de gastro-enterostomie. Richard von Volkmann deed in 1878 als eerste een verwijdering van het rectum wegens kanker. James Marion Sims was een Amerikaans chirurg, die al voor de tijd van de anaesthesie leverabcessen draineerde. In 1878 voerde hij als eerste een cholecystectomie en drainage uit. In 


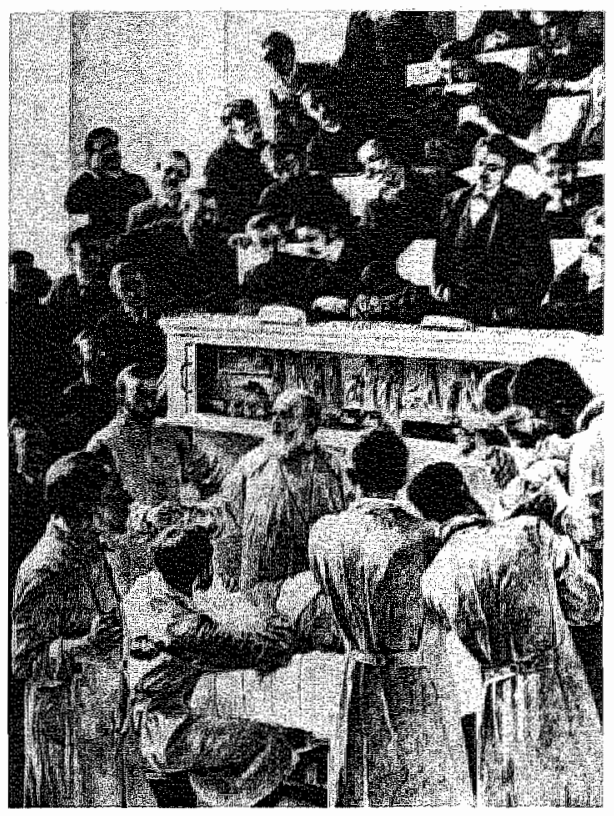

Figurur 3.3

Theodor Billroth geefi college te Wenen. Naar een schilderij van A.F. Seligmann (1880)

(Bron: Dr. M.A. Verschuyl; Met naald en draad, van mier tot niet; 1988)

1852 ontwikkelde hij een techniek tor sluiting van de, tot die tijd onbehandelbare, vesicovaginale fistel. William Stewart Halsted, chirurg te Baltimore U.S.A., was de eerste die gebruik maakte van rubber operatiehandschoenen (1890). Naast de ontwikkeling van de radicale mastectomie bij kanker is hii de eerste geweest die experimenteerde met locale infiltratie-anaesthesie door cocaine.

Grote chirurgen op gynaecologisch terrein zijn Ephraim Mc Dowell (verwijderde reeds in 1809 per laparotomie een ovariaalcyste), Sir Thomas Spencer Wells (ovariëctomie 1858) en Robert Lawson Tate, die bijna een pionier was in vrijwel alle denkbare gynaecologische operaties.

De appendectomie, nu een van de gewoonste operaties, is pas aan het einde van de vorige eeuw algemeen geworden. In 1867 werden door de Amerikaan William Parker drie belangrijke stadia bij een appendicitis onderscheiden: gangreen, perforatie en abces. Hij beschreef vier succesvolle drainages van abcessen en betoogde dat de optimale tijd voor incisie tussen de vijfde en twaalfde dag lag. Van een vroege verwijdering van de appendix was in die tijd nog geen sprake. De algemeen toegepaste therapie bestond uit afwachten en, in geval van abcedering, incisie (perityphlitisch abces). Pas in 1884 beval Samuel Fenwick, arts in het London Hospital, vroeg-operatie bij appendicitis aan. Zijn advies vond geen weerklank.

De eigenlijke grondlegger van de kennis over en de therapie bij appendicitis was Reginald Heber Fitz uit Boston, U.S.A.. De term "acute appendicitis" is door hem het eerste gebruikt en hij demonstreerde in 1886 aan de hand van 500 obductieverslagen dat perfora- 
tie van de ontstoken appendix snel tot peritonitis kon leiden. Hij trok dan ook de conclusie dat een ontstoken appendix in een vroeg stadium diende te worden werwijderd. Er kwamen, in het kielzog van deze conclusies, al snel uitstekende onderzoekingen naar de diagnostiek van de vroege appendicitis op gang. De Amerikaanse chirurgen Sands, McBurney en Murphy hebben zich hierbij onderscheiden. In 1887 werd in de Verenigde Staten door Morton voor het eerst in de geschiedenis een appendectomie verricht op grond van een pre-operatief correct gestelde diagnose.

In Europa is men lange tijd erg terughoudend gebleven als het op opereren van een appendicitis aankwam. Koning Edward VII van Engeland werd in 1901 nog op de oude manier behandeld: men wachtte abcesvorming af waarna deze werd geincideerd. Hij heeft het overleefd. De Duitse president Ebert is in 1925(!) aan de gevolgen van een conservatieve houding ten aanzien van zijn appendicitis overleden.

Sluiting van perforaties van de tractus gastro-intestinalis door middel van spoedlaparotomie en overhechting, werd in 1884 voor het eerst uitgevoerd door de Duitse chirurg Johann von Mikulicz.

Op grond van de ontwikkelingen in anatomie, pathologische anatomie, fysiologie en pathofysiologie in de loop van de achttiende en negentiende eeuw, werden steeds meer de verschillende mogelijke oorzaken van het ontstaan van acute buikpijn onderscheiden. $\mathrm{Na}$ introductie van de anaesthesie en de asepsis werd het mogelijk grotere, ingewikkelder en langduriger operaties uit te voeren. De meer verfijnde kennis over de oorzaken en de diagnostiek van acute buikaandoeningen ontstond pas met het voortschrijden van de chirurgische therapie. De in onze tijd gebruikelijke systematische diagnostiek bestaande uit anamnese, lichamelijk onderzoek en aanvullend onderzoek, kreeg dan ook pas gestalte tijdens de laatste decennia van de negentiende eeuw en vond algemene toepassing tijdens de eerste decennia van de twintigste eeuw. Veel uitstekende en nu nog veel gebruikte leerboeken dateren uit die jaren (Cope, 1921, Mondor 1930). Na lezing van deze werken wordt duidelijk hoe in een tijdsbestek van krap vijftig jaar bijna de hele moderne diagnostiek van acute buikklachten werd ontwikkeld samen met de geëigende, meestal chirurgische, geneeswijze. Het proces van verfijning der diagnostiek, met als gevolg een scherpere indicatiestelling voor een bepaalde therapie en van verbetering van deze therapie zelf, is nog in volle gang. 



\section{Hoofdstuk 4}

\section{TOPOGRAFIE DER BUIKORGANEN}

Anatomisch inzicht is bij de beoordeling van acute buikklachten onontbeerlijk. Buikonderzoek is dikwijls niet volmaakt omdat de onderzoeker een belangrijke voorwaarde over het hoofd ziet: het toepassen van een voldoende kennis der anatomie (Cope 1979). In dit hoofdstuk wordt een synopsis gegeven van de normale situs en syntopie van de buikorganen en de belangrijkste variaties ervan in grootte en ligging.

\subsection{Buikwand, peritoneum}

De buikorganen worden omgeven door een omhulsel van spieren, bot, kraakbeen, bindweefsel, huid en de passerende structuren. Op de buikhuid zijn min of meer vaste punten uit te zetten waarnaar de plaats van de buikorganen af te meten is. De topografie en syntopie van deze markeringspunten zijn niet altijd even betrouwbaar. Er zijn aanzienlijke variaties mogelijk in de buikholte, maar ook in de buikwand.

Pathologische veranderingen in en aan de buikwand zijn bij de diagnostiek van belang (défènse musculaire, meteorisme, verminderde ademexcursies enzovoorts). In figuur 4.1 is de projectie van de verschillende buikorganen op de voorste buikwand weergegeven.

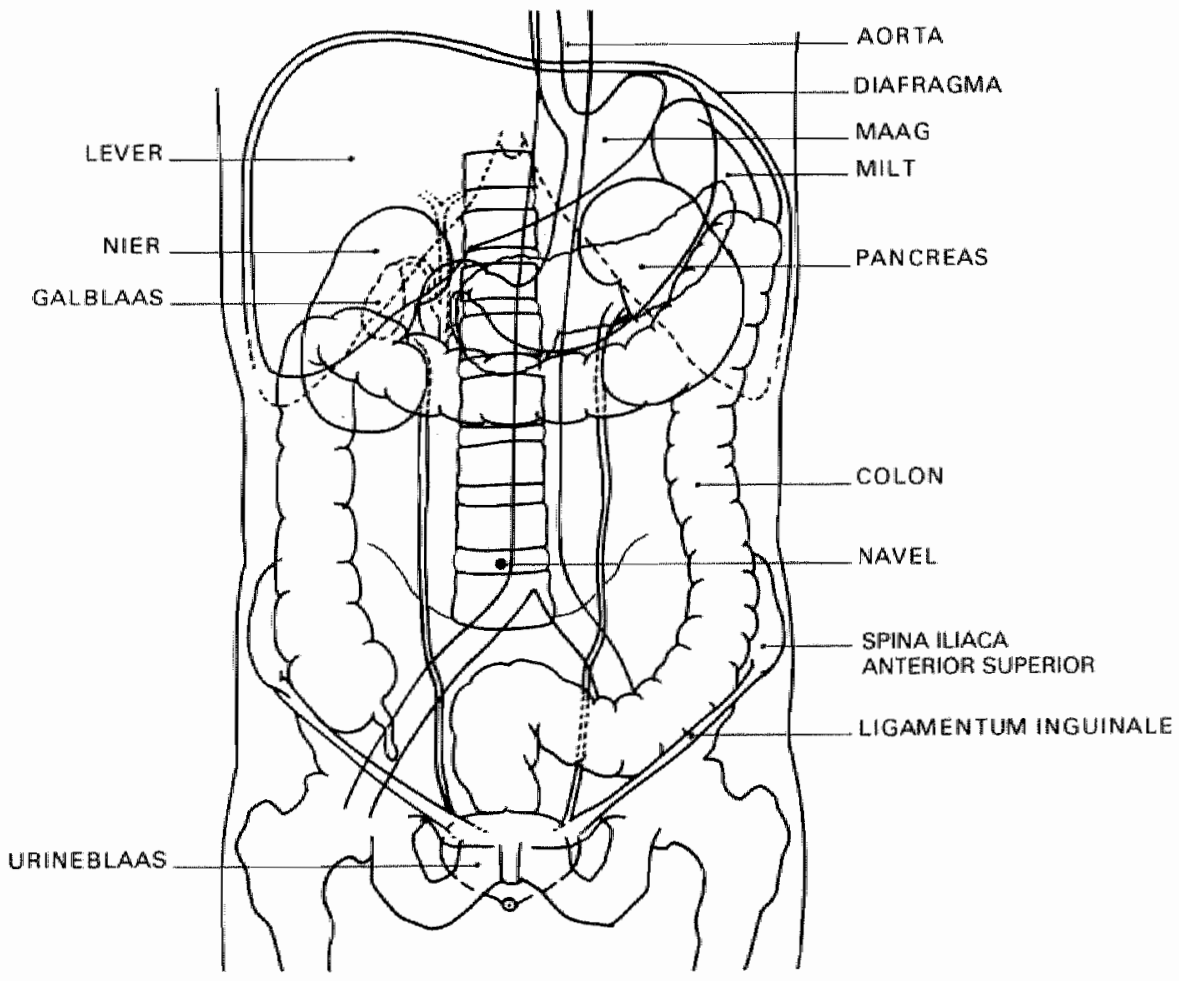

Figuur 4.1

Projectie van de verschillende organen op de voorste buikwand. 
Een belangrijke omhullende structuur van buikholte en buikorganen is het peritoneum. Het de buikorganen direct omringende peritoneum wordt peritoneum viscerale genoemd; de buikwand wordt aan de binnenzijde bekleed door het peritoneum pariëtale. Het peritoneum vormt een gesloten zak, die tijdens de embryonale ontwikkeling veel nissen en plooien kreeg (bursa omentalis, omentum majus). Macroscopisch is het glad en glanzend. Door deze eigenschap kunnen de buikorganen gemakkelijk over elkaar heen glijden. Het peritoneum pariëtale is, in tegenstelling tot het peritoneum viscerale, net zo gevoelig als de huid. Dit verschil is van diagnostische betekenis. In hoofdstuk 5 wordt hierop teruggekomen. Door het grote oppervlak ervan (bijna $2 \mathrm{~m}^{2}$ ) en de rijke vaatvoorziening van het peritoneum kunnen grote hoeveelheden vloeistof, maar ook toxinen en bacteriën, worden opgenomen en doorgelaten. Verspreiding van materiaal gaat in de buikholte snel door de bewegingen van de buikwand bij ademhalen, door de darmperistaltiek en door de zwaartekracht. Permeabiliteit van het peritoneum en snelle verspreiding van het materiaal zijn van betekenis bij pathogenese en symptomatologie.

\subsection{Buikorganen}

Situs en syntopie van de verschillende buikorganen kunnen erg variëren. Zo is de maag wat grootte betreft veranderlijk, afhankelijk uiteraard van vullingstoestand en van individuele omstandigheden (leeftijd, constitutie). De grondvorm blijft echter in grote lijnen steeds dezelfde. Het colon transversum kan sterk in lengte variëren waardoor het diepste punt van de "guirlande" tot in het kleine bekken kan reiken.

Van grote diagnostische betekenis is het gegeven dat het caecum en de appendix vermiformis door liggingsanomalieën van de eerste en door vorm- en lengtevariaties van de tweede, zich in principe in de gehele rechter buikhelft kunnen bevinden. Het is van belang zich deze variaties te realiseren bij het diagnostiseren van acute buikaandoeningen. Een sagittale mediane doorsnede van de buik is te zien in figuur 4.2:

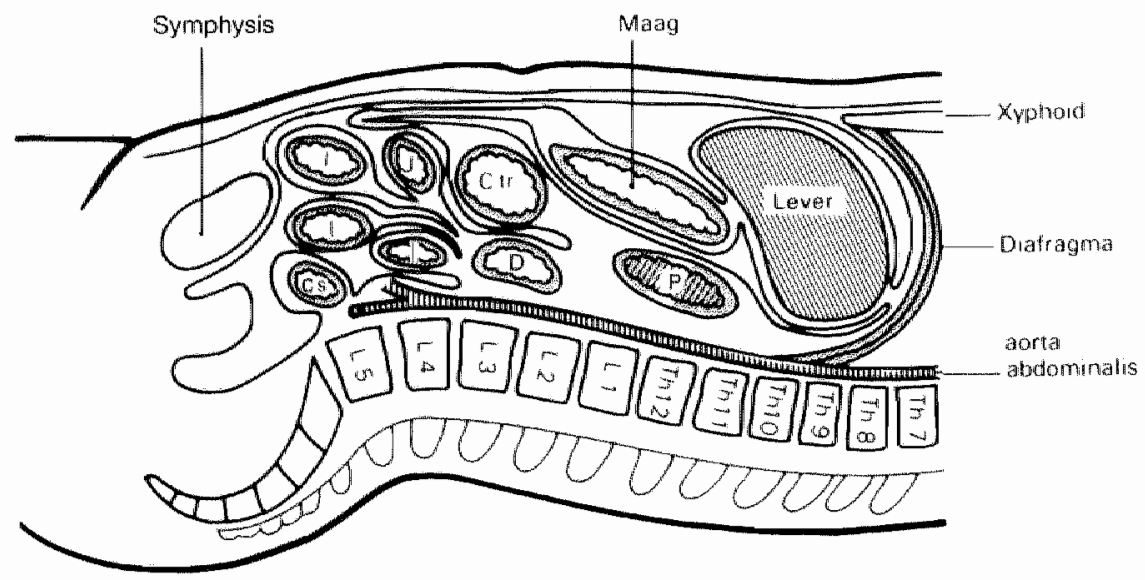

Figutr 4.2

Sagittale mediane doorsnede van de buik

$\mathrm{C} \mathrm{r}_{\mathrm{c}}=$ Colon transversum $\quad \mathrm{J}=$ Jejunum

$\mathrm{I}=$ lleum $\quad \mathrm{D}=$ Duodenum

$\mathrm{Cs} .=$ colon sigmoideum $\quad \mathrm{P}=$ Pancreas 
In figuur 4.2 wordt aangegeven hoe de verschillende buikorganen gesitueerd zijn ten opzichte van het peritoneum. De positie ten opzichte van het peritoneum is bij pathologische processen van belang met betrekking tot symptomatologie en diagnostiek.

Nieren en urineblaas liggen geheel retro-peritoneaal. De genitalia interna van de vrouw liggen in het kleine bekken, gedleeltelijk bedekt door peritoneum.

Omdat de doelstelling van de Acute Buik Analyse niet primair de analyse van de symptomatologie van acute buikklachten aangaat, wordt niet diepgaand op de anatomie ingegaan. Voor verdere informatie moge verwezen worden naar leerboeken als Töndury, Angewandre und topographische Anatomie, 1965 en Sobotta Becher, Atlas der Anatomie des Menschen, 1965. 



\section{Hoofdstuk 5}

\section{(BUIK)PIJN}

"Pijn is ten diepste de ervaring

van de broosheid van het bestaan"

Illich, 1975.

\subsection{Begripsomschrijving}

Elk mens heeft een pijngevoel. Een leven zonder pijn is nier alleen een utopie, maar zou ook onwenselijk zijn. Pijn is een uitdrukking van iets, pijn waarschuwt, signaleert. Volgens bepaalde religieuze opvattingen heeft pijn een positieve waarde, bijwoorbeeld als straf of als beproeving.

Bij een poging om tot definiëring van het begrip pijn te komen blijkt dat men het vanuit verschillende invalshoeken kan benaderen. Van Dale's Groot Woordenboek van de Nederlandse Taal geeft zes verklaringen voor het woord pijn:

- straf;

- lichamelijk lijden;

- pijniging;

- nood;

- zielleleed;

- moeite of moeizaamheid.

Het is duidelijk dat onaangenaamheid hier het gemeenschappelijk kenmerk is. In geneeskundig opzicht zijn vooral het lichamelijk lijden, de nood en het zieleleed van toepassing op het begrip pijn.

Andere begripsomschrijvingen luiden als volgt:

- op de vraag wat pijn nu eigenlijk is moet van de kant van de psycholoog een zeer kort en naar ik vrees zeer teleurstellend antwoord worden gegeven: hij heeft geen ideel (Menges 1979);

- pijn is pas pijn als het als zodanig onaangenaam wordt ervaren of kernachtiger: it is pain when it hurts (Voorhoeve 1979);

- pijn is de beleving van neurogene signalen uit de periferie die uiteindelijk in de gyrus post-centralis van de hersenschors arriveren (Kuijjer 1983).

Op objectieve gronden is het niet goed mogelijk om tot een goed handelbare definitie van het begrip pijn te komen. Bij pijn gaat het vooral om de pijntolerantie en de totale pijnbeleving. Deze worden krachtig beinvloed door factoren en omstandigheden die zich geheel of grotendeels aan objectieve maatstaven onttrekken (Merksey 1973, Johnson \& Rice 1974).

De fysiologie van de pijn is dan ook in veel opzichten de fysiologie van emoties. De medicus practicus doet er echter goed aan pijn in eerste instantie te beschouwen als cen signaal dat op weefselbeschadiging duidt. In de overgrote meerderheid van de gevallen berust pijn daar ook op (Voorhoeve 1979). Aan het begrip pijn zijn dan ook drie hoofdzaken te onderscheiden: de oorzaak, de geleiding en de gewaarwording. 


\subsection{Oorzaak}

Door prikkeling van een zintuig ontstaan impulsen in de zenuwuiteinden welke weer aanleiding zijn tot een verandering van het impulspatroon in het centrale zenuwstelsel. Een zintuig bestaat uit receptoren; prikkeling daarvan kan tot gevolg hebben: een reflex, een bewustzijnsverschijnsel of beide. Zoals bekend bezit de mens vijf zintuigen. Behalve bij de reuk en smaak kan elke zintuigelijke prikkel bij voldoende intensiteit piingevoel geven. Pijn is, zoals de temperatuurs- en aanrakingszin, een van de gevoelsmodaliteiten. Pijn wijkt in die zin van de andere zintuigelijke waarnemingen af, dat het ons niets rechtstreeks mededeeit over de oorzaak ervan. Tenzij andere modaliteiten tegelijkertijd geprikkeld worden kunnen wij niet zeggen of de piin door kou, een slag, chemische stoffen enzovoort wordt veroorzaakt.

Zoals all eerder opgemerkt is weefselbeschadiging de meest voorkomende oorzaak van pijn. Vormen waar geen evenredige verhouding bestaat tussen de ernst van de pijn en de ernst van de weefselbeschadiging op dar moment zijn bijv. fantoompijn of chronische lumbago van onbekende genese (psychogeen). Op de meer precieze werking van de receptie van pijnprikkels wordt in deze studie niet ingegaan. Dit zou te ver voeren. Uit literatuuronderzoek bleek dat over de nociceptie in de buikholte niet veel bekend is. Mogelijk is er niet veel verschil met de piinreceptie elders in het lichaam.

\subsection{Geleiding}

Nadat een schadelijke prikkel in de buik een pijn-impuls heeft veroorzaakt, wordt deze ter gewaarwording naar het centrale zenuwstelsel vervoerd. De sensibele innervatie van de buikwand en het peritoneum pariëtale wordt verzorgd door de nn. intercostales th. VI $\mathrm{t} / \mathrm{m}$ XII en door de nn. iliohypogastricus en ileoinguinalis lumb. I en II vanuit de plexus lumbalis. Het gedeelte van het peritoneum dat met het diafragma verkleefd is wordt sensibel geinnerveerd door de n. phrenicus uit C-IV.

De buikingewanden en het peritoneum viscerale worden sensibel geïnnerveerd via vezels die in het mesenterium samenlopen met de sympathicus. Alle afferente zenuwen uit de buikholte convergeren in het ganglion coeliacum in de plexus solaris (figuur 5.1). Van hieruit gaan ze samen met de $\mathrm{n}$. splanchnicus major et minor. Ze passeren het diafragma en eindigen in de truncus sympathicus in de thoracale ganglia VI t/m XII. In deze sympathische ganglia kunnen de vezels nog naar een hoger of lager niveau. Via de rami communicantes gaan ze samenlopen met de spinale zenuwen. In het ruggemerg wordt overgeschakeld op het tweede neuron. Vanuit de achterhoorn vindt de decussatie plaats, waarna de afferente banen opstijgen met de tr. spino-thalamicus (en waarschijnlijk nog met andere zenuwbanen, Voorhoeve 1979) via de lemniscus medialis naar de thalamus. Van hieruit gaan de vezels via de tr. thalamo-corticalis naar de gyrus postcentralis (Weber, 1960).

Het afferente zenuwverloop wordt schematisch weergegeven in figuur 5.1: 


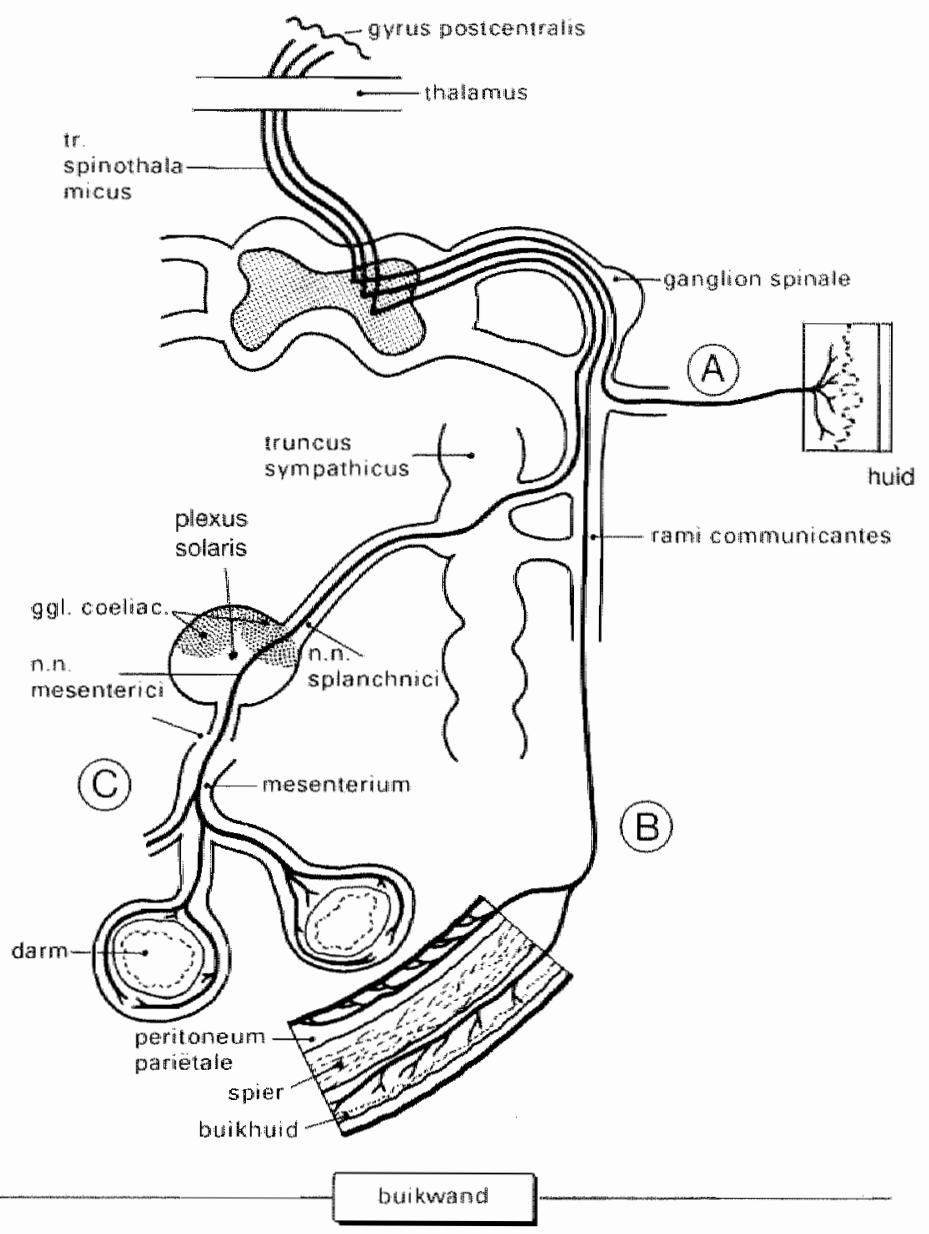

Figuar 5.1

Schematische weergave van de sensibele zenuwbanen van de buikorganen en de huid.

A. Sensibele huidzenuw behorende tot het cerebro-spinale zenuwstelsel.

B. Afferente sensibele vezels uit buikhuid en peritoneum, eveneens behorende tot het cerebro-spinale systerm.

C. Afferente vezels uit de buikorganen, meelopend met het autonome zenuwstelsel; in het mésenterilim samen met parasympathische en sympathische vezels, na het ganglion coeliacum uitsluitend samen met sympathische vezels.

De zenuwvezels, die de buikwand sensibel verzorgen zijn sterk gemyeliniseerd, geleiden snel en zijn groot in aantal en doorsnede. Het pariëtale peritoneum is even gevoelig als de huid. De afferente sensibele vezels van peritoneum viscerale en buikorganen zijn minder gemyeliniseerd, geleiden minder snel en zijn geringer in doorsnede en aantal. Het peritoneum viscerale is dan ook minder gevoelig dan het peritoneum pariëtale. 


\subsection{Gewaarwording}

Gewaarwording is de subjectieve beleving die tot stand komt door prikkeling van een zintuig of zintuigsysteem (Voorhoeve 1980). Deze subjectieve beleving komt, zoals algemeen wordt aanvaard, tot stand in de hersenschors; tactiele prikkels eindigen in de gyrus postcentralis. Pijn is een gevoelsmatige entiteit. In die zin moeten er twee hoofdzaken aan worden onderscheiden: emotionele expressie en emotionele beleving. Voor de onderzoekende arts zijn zij nooit helemaal invoelbaar. Emotionele expressie is in zekere zin te objectiveren. Bij emoties kunnen de z.g. "fight, fright an flight reactions" optreden. Zij berusten op een verhoogde sympathicus-activiteit. Zo kunnen als gevolg van pijn of angst de haren overeind gaan staan, kunnen de pupillen zich verwijden en kan de frequentie van hartslag en ademhaling toenemen.

De emotionele beleving speelt zich af in de hersenschors. Er moet vanuit worden gegaan dat emoties als gevoelens of belevingen berusten op de activiteit van een zeer groot aantal hersencellen. Het oplossend vermogen van de huidige analysetechnieken is niet voldoende om deze acriviteiten vast te leggen en te begrijpen. In een aantal studies is wel vastgesteld dat er met betrekking tot pijn sprake is van culturele bepaaldheid. Hierdoor bestaan er bijv. verschillen in pijnbeleving en pijngedrag tussen bepaalde beroepsgroepen zoals soldaten en burgers (Edelstein 1974).

De overgang van het fysische naar het psychische en omgekeerd is nog altijd onduidelijk terrein en is niet in maat en getal uitdrukbaar (Menges 1979). Belevingen blijven in laatste instantic een zuiver subjectief begrip (Voorhoeve 1979).

\subsection{Soorten buikpijn}

Aan de hand van gewaarwording en expressie kunnen drie soorten buikpijn worden onderscheiden (Kuijijer 1983):

1. pariètale of somatische buikpijn;

2. viscerale buikpijn;

3. gerefereerde pijn.

Zoals later duidelijk zal worden is dit onderscheid bij de diagnostiek van acute buikpijn erg bruikbaar. Ze worden achtereenwolgens toegelicht.

\subsubsection{Pariëtale of somatische buikpijn}

Pariëtale of somatische buikpijn ontstaat door schadelijke prikkeling van de sensibele zenuwuiteinden in het peritoneum pariètale. De baan van de impulsen is weergegeven in fig. 5.1. Pariëtale pijn wordt in het algemeen als continu en scherp van karakter ervaren en bezit dezelfde kwaliteiten als pijn, komend vanuit de huid. Zij is door de patiënt doorgaans makkelijk te localiseren en kan meestal met één vinger aangewezen worden (Müller en Henneman 1972). De pijn wordt altijd in het gebied van het betrokken segment gevoeld. Bewegen doet de pijn toenemen, de patiënt neigt tor stil liggen (Saclarides 1986). Voorbeelden van aandoeningen die in eerste instantie vooral pariëtale buikpijn tot gevolg hebben zijn pancreatitis en het gebarsten aneurysma van de aorta abdominalis. 


\subsubsection{Viscerale buikpijn}

Viscerale buikpijn ontstaat door schadelijke prikkeling van de sensibele zenuwuiteinden in de buikorganen en het peritoneum viscerale. De pijnprikkels worden voortgeleid via zenuwbanen parallel aan die van de sympathicus. Het niveau waarop ze het ruggemerg binnenkomen hangt af van het segment, waar het betreffende orgaan in zijn embryologische periode is ontstaan. De pijn wordt als moeilijk localiseerbaar aangegeven en zit soms ongeveer op een plaats, overeenkomend met het niveau van binnenkomst in het ruggemerg. De pijn wordt vaak gevoeld in de mediaanlijn en de plaats wordt door de patiënt vaak aangegeven met een draaiende beweging van de hand boven, midden of onder op de buik, terwijl soms de héle buik wordt aangeduid (Müller en Henneman 1972). De uitbreiding van het ziekteproces en de aard van de prikkel bepalen mede de intensiteit van pijnervaren (Saclarides 1986). Kuijjer (1983) brengt in de localisatie van de pijn enkele differentiaties aan: pijn in de mediaanlijn bij aandoeningen van het spijsverteringsstelsel, laag retrosternaal en bovenin de buik bij aandoeningen tot en met het tweede deel van het duodenum (voordarm), rond de navel bij aandoeningen van het derde deel van het duodenum tot de flexura coli sinistra (middendarm) en in het midden van de onderbuik bij aandoeningen van de rest van het spijsverteringsstelsel (einddarm). Over de waarde van deze theorieën is geen relevante literatuur gevonden. Viscerale pijn veroorzakende prikkels zullen hun oorsprong in het algemeen vinden in mechanische en/of chemische schadelijke inwerking. Kramp, trek en druk met ischaemie is niet zeldzaam (Saclarides, 1986). Ontsteking komt uiteraard vaak voor. Doordat de afferente vezels in de buik samenlopen met de sympathicus kunnen door medestimulatie hiervan vegetatieve bijverschijnselen optreden zoals braken, onrust, transpireren, polsversnelling en bloeddrukverlaging. Pariëtale en viscerale pijn kunnen natuurlijk ook naast elkaar voorkomen.

Zo kunnen bij een acute appendicitis rek of druk ontstaan in de appendix en zijn meso (viscerale pijn), maar tevens kan het peritoneum pariëtale geprikkeld zijn (pariëtale pijn). Voorbeelden van aandoeningen waarbij in eerste instantie viscerale pijn op de voorgrond staat zijn obstructie-ileus en galsteenkoliek.

\subsubsection{Gerefereerde pijn}

Hiervan wordt gesproken als pariëtale of viscerale pijn wordt gevoeld en gelocaliseerd in een huidgebied (Kuijjer 1983). De pijn wordt dan op een andere plaats gevoeld dan waar het ziekteproces is gelocaliseerd (Müller en Henneman 1972). Het beste voorbeeld om het begrip gerefereerde pijn mee te illustreren is de plaats van ontstaan en de uiteindelijke situs van het diafragma. Het diafragma ontstaat ter hoogte van het vierde cervicale segment. Door de groei van hart en longen daalt her af en uiteindelijk is de origo ervan de binnenzijde van het processus styloideus sterni en de ventrale zijden van de wervellichàmen L-2 tot 4 . Bij prikkeling van het peritoneum dat aan de onderzijde met het diafragma vergroeid is, kan er pijn gevoeld worden in die huidgedeelten, welke men ook wel eens de "epauletten" noemt.

Een ander voorbeeld is pijn in de linker arm bij een myocardinfarct of pijn over de rechter ribbeboog bij ontsteking van de galblaas. Deze huidzones worden Head'se zones genoemd naar hun eerste beschrijver, de Engelse neuroloog Head, geboren in 1861. Een volgende 
verklaring lijkt redelijk: in de achterhoorn is convergentie aangetoond van sensibele vezels, komend vanaf het lichaamsoppervlak en van sensibele vezels komend uit de buikorganen (Voorhoeve 1979). De opstijgende pijnvervoerende tr. spino-thalamicus zou minder axonen bevatten dan er in de achterhoorn samenkomen. In dat geval kunnen de inkomende prikkels niet tegelijkertijd door het ruggemerg vervoerd worden en dus krijgt het cerebrum verkeerde informatie. Het cerebrum nu gaat prioriteiten stellen. Omdat de huid als belangrijk sensibel orgaan in onze beleving prevaleert boven de ingewanden, wordt de pijn gevoeld alsof ze afkomstig is van de huid (Kuijjer 1983). Het betreft dan dat huidgedeelte wat behoort bij het segment op de hoogte waarvan de pijnprikkel het ruggemerg is binnengekomen.

De gerefereerde pijn heeft de kwaliteiten van pariëtale pijn, maar is meestal minder hevig (Kuijjer 1983). Er kan zelfs spierspasme optreden in het bijbehorende spiersegment (défènse musculaire). Naast de drie hier genoemde soorten buikpijn bestaan er nog andere fenomenen: hyperalgesie, irradiatie en geprojecteerde pijn. Ze worden achtereenvolgens besproken.

\subsection{Hyperalgesie}

Verhoogde pijngevoeligheid in een ontstekingsgebied zou verklaard kunnen worden door het volgende: bij weefselbeschadiging komen verscheidene stoffen zoals $\mathrm{K}^{+}$en $\mathrm{H}^{+}$-ionen vrij evenals histamine bradykinine enzovoort. Deze stoffen, die zelf pijn kunnen veroorzaken, kunnen tevens als modulator functioneren die de zenuwmembranen gevoeliger maken voor andere inwerkingen (Voorhoeve 1979).

\subsection{Irradiatie}

Gerefereerde pijn en uitstraling of irradatie zijn begrippen die nogal eens door elkaar worden gehaald maar die elkaar toch niet geheel dekken (Müller en Henneman 1972). Uitstraling houdt in het door de patiënt ervaren fenomeen dat hij de pijn vanuit het aangedane orgaan voelt uitstralen naar een ander gebied (dit in tegenstelling tot gerefereerde pijn). De uitstraling volgt het zenuwverloop van het betrokken segment van het ruggemerg. Voorbeelden ervan zijn pijn in de onderpunt van de scapula uitgaande van de rechter bovenbuik bij galblaasontsteking (Th-VIII), trekkende pijn naar de homolaterale lies en testikel bij niersteenkoliek (n.ilio-inguinalis) en uitstraling van de pijn naar rug en heupen bij een rupturerend aneurysma van de aorta abdominalis ( $L-1$ enII). De pijn volgt het zenuwverloop van het betrokken segment. Bij gerefereerde pijn wordt dus niet steeds pijn gevoeld in het aangedane orgaan terwijl dit bij irradiatie altijd het geval is.

\subsection{Geprojecteerde pijn}

Hiervan spreekt men als door prikkeling van sensibele zenuwen pijn ontstaat distaal van het ontstaanspunt. Voorbeelden zijn herpes zoster, fantoompiin, neuralgieën en radiculaire syndromen (Kuijjer 1983). Voor de diagnostiek van de acute buik is deze pijnvorm niet van belang. 


\section{Hoofdstuk 6}

\section{HET KLINISCHE BESLISSINGSPROCES}

..."Examine from the hend to toes Before you dare to diagnose

More harm is done because you do not look

Than from not knowing what is in the book"...

Zeta, 1955.

\subsection{De diagnose als onderdeel van het klinische beslissingsproces}

Een diagnose, door van Dale's Groot Woordenboek van de Nederlandse Taal omschreven als: "het onderkennen van de aard en de zetel van een ziekte of kwetsuur uit de verschijnselen" is een zeer wezenlijk onderdeel van het klinische beslissingsproces. Het klinische beslissingsproces omvat alle handelingen en overwegingen door de onderzoekende arts, vanaf het eerste contact met de patiënt tot aan de oplossing van het diagnostische en therapeutische probleem. Wulff (1980) heeft het klinische beslissingsproces als volgt in schema gebracht (figuur 6.1):

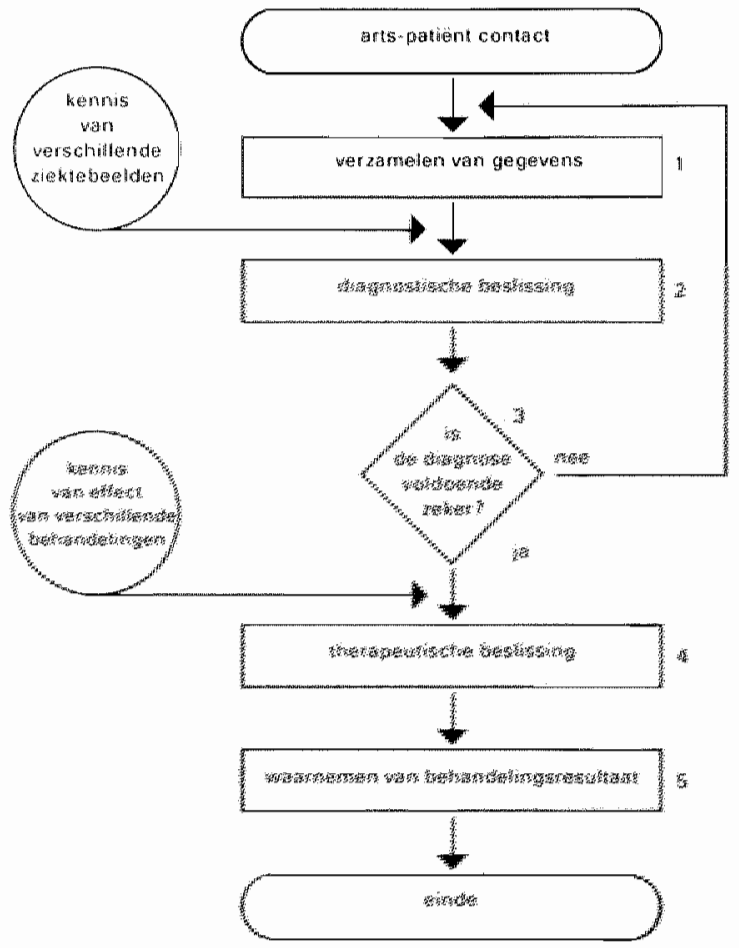

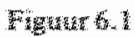

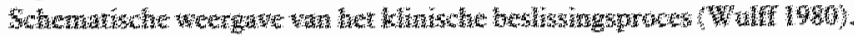


De volgorde van de verschillende fasen kan natuurlijk wisselen: een therapeutische beslissing kan immers al best genomen worden voordat er een exacte diagnose is gesteld. Een voorbeeld hiervan is shockbestrijding. In het kort worden de fasen achtereenvolgens behandeld.

\section{Arts-patiënt contact.}

Het contact tussen de patiënt en de arts komt meestal tot stand op initiatief van de patiënt. De klachten, die hem ertoe bewogen om medische hulp in te roepen worden iatrotrope klachten genoemd. Iatrotrope klachten vormen in de ogen van de patiënt het hoofdprobleem. $\mathrm{Zij}$ kunnen verschillend van aard zijn: onaangenaam, alarmerend, onduldbaar enzovoort. Meestal is het een combinatie en soms ligt de zaak nog gecompliceerder: de patiënt kan (dis)simuleren of kan een minder belangriike klacht presenteren in de hoop dat de echte klacht ook ter sprake komt.

\section{Verzamelen van gegevens.}

$\mathrm{Na}$ het eerste arts-patiënt contact begint het diagnostische proces. Gegevens moeten worden verzameld, de zogenaamde nosografische of ziektebeschrijvende kenmerken. Deze kenmerken tesamen vormen het ziektebee]d. Feinstein (1967) heeft een classificatie van ziektebeschrijvende kenmerken samengesteld:

1. demografische gegevens (leeftijd, geslacht, naam, enzovoort);

2. subjectieve klachten (deze worden door de patient aan zichzelf ervaren zoals misselijkheid, nervositeit, pijn, enzovoort);

3. objectieve klachten (deze omvatten alle waarnemingen door de patiënt aan zichzelf, die objectief te bevestigen zijn zoals oedemen, icterische sclerae of haematurie; waarnemingen van omstanders of familie mogen ook tot de objectieve klachten worden gerekend);

4. lichamelijke afwijkingen (alle afwijkingen die de arts vindt tijdens het lichamelijk onderzoek); het lichameliik onderzoek kent subjectieve bevindingen (alleen door de patiènt waar te nemen bij een bepaalde handeling door de onderzoekende arts zoals losilaat- en drukpijn) en objectieve bevindingen (palpabele weerstand, défènse musculaire, arteriële pulsaties, enzovoort); verschijnselen die de patiënt uitsluitend ervaart tijdens het lichamelijk onderzoek worden geprovoceerde klachten genoemd;

5. paraklinische gegevens; deze komen voort uit het anvullend onderzoek (bloed, urine, echo, röntgenonderzoek, enzovoort).

\section{Diagnostische beslissing.}

Op grond van de verzamelde gegevens en met behulp van een voldoende kennis van de verschillende ziektebeelden wordt een diagnostische beslissing genomen ofwel een diagnose gesteld. Tijdens deze procedure is het van belang de verzamelde gegevens volgens een strak en vast patroon af te werken. Op deze wijze wordt het eenvoudiger om ervaringen en klinische beelden in het geheugen op te nemen en later weer in de herinnering terug te roepen bij het overwegen van de eventuele diagnose. Daarbii geeft deze manier van werken een groot gevoel van voldoening dat slechts weinig afneemt als de gevolgtrekkingen onjuist blijken te zijn (Cope 1979). Waarschijnlijk heeft iedere klinikus zijn eigen methoden om tot een diagnose te komen. Toch zijn er in de benadering van de diagnose drie hoofdtypen te onderscheiden: 
1. patroonherkenning: het herkennen van een klinisch beeld uit leerboek en/of ervaring;

2. causale benadering: deze is gebaseerd op kennis van parhogenetische mechanismen; een patiënt met een bifurcatie-prothese die een pulserende zwelling in de lies kriigt heeft een naad-aneurysma;

3. waarschijnlijkheidsbenadering: het schatten van de kans dat een diagnose juist is; een geriatrische patiënt met bloed bij de faeces en een veranderd defaecatie-patroon heeft een zeer grote kans om een colon-carcinoom te hebben.

Hoewel therapeutisch beleid in de praktijk soms woor de diagnose komt wordt het stellen wan een diagnose als een eerste vereiste beschouwd (Wulff 1980, Cope 1979, en vele anderen), omdat zonder een diagnose het kiezen van een therapie, die de beste prognose heeft, niet mogelijk is. Een goede diagnose heeft immers voorspellende waarde. Het stellen van de diagnose appendicitis of geruptureerd aneurysma van de abdominale aorta bijvoorbeeld heeft als consequentie: operatie op korte termijn.

Voorwaarde om aan een diagnose voorspellende waarde toe te kennen is natuurlijk wel dat er bruikbare definities worden ontwikkeld voor de namen der ziektes en dat men ook bereid is deze definities in de dagelijkse praktijk te aanvaarden en toe te passen (consensus). Zo kan een Babylonische spraakverwarring met al haar nare gevolgen worden voorkomen. Wulff (1980) onderscheidt de volgende soorten diagnoses:

1. klachtendiagnose: de oorzaak van de klacht is (of blijft) onduidelijk (Non Specific Abdominal Pain, psychogene buikpijn, enzovoort);

2. syndroom (bijvoorbeeld: syndroom van Horner: ptosis, myosis, enophtalmus);

3. anatomisch gedefinieërde diagnose: hierbij wordt de laesie en de plaats van de laesie aangeduid (cholelithiasis, appendicitis enzovoort);

4. causaal gedefinieërde diagnose (cholera, hyperaldosteronisme enzovoort).

Hoewel figuur 2.1 suggereert dat bij acute buikpijnen verreweg de meeste diagnoses wel anatomisch gedefinieërd zullen zijn is dit in de praktijk toch niet waar. Het blijkt namelijk dat een aanzienlijk aantal acute buikklachten onopgehelderd blijft: men komt daarbij niet verder dan een klachtendiagnose (De Dombal 1980). Van dergelijke diagnoses is de voorspellende waarde natuurlijk erg wisselend. Afhankelijk van de ernst waarmee het beeld imponeert moet besloten worden tot verwijzing, opname in her ziekenhuis of operatie.

Na het stellen van de diagnose kan de arts twee dingen doen:

1. hij kan genoegen nemen met deze beslissing en overgaan tot de therapeutische procedure;

2. hij is niet tevreden en zal de procedure terugkoppelen naar het stadium van het verzamelen der gegevens (figuur 6.1).

Bij het kiezen voor een van de twee beslissingen zal de arts zich er terdege van bewust dienen te zijn dat er altijd risico bestaat met betrekking tot vergissen of complicaties. Hij zal dan ook proberen een "rampenplan" te maken: wat te doen als blijkt dat hij of zij ongeliik heeft of als er iets fout gaat. De arts past dan, misschien onbewust, het zogenaamde "minimax-loss-principle" toe. Dit principe behoort tot de spelstrategie en het doel ervan is om het maximaal te verwachten verlies zo klein mogelijk te houden ofwel "to select that strategy, which would have the least ill-effects, if the worst possible outcome 
happened" (W'ulff 1980). De kunst nu van het memen van een diagnostische/therapeutische beslissing is het vinden van een synthese tussen de pure waarschijnlijkheidsstrategie en het minimax-principle: met zo weinig mogellijk "kosten" (risico en ongerief voor de patiënt, financieel) zo hoog mogelijke baten (effectieve therapie) proberen te verkriigen.

\section{Therapeutische beslissing.}

Meestal na het stellen van de diagnose wordt er beslist over de in te stellen therapie. Soms echter kan er al een therapie worden gestart vóordat de diagnostische beslissing is genomen.

De consequenties van een therapeutische beslissing kunnen zijn: verwijzing, opname, conservatieve of operatieve therapie, enzovoort.

\section{Waarnemen wan het behandelingsresultaat.}

Tijdens deze fase wordt het beloop van de aandoening geobserveerd. Indien de therapeutische procedure niet het gewenste resultaat heeft kan teruggekoppeld worden naar eerdere stadia van de klinische beslissingsprocedure (figuur 6.1).

\section{Einde van het klinische beslissingsproces.}

$\mathrm{Bij}$ totaal herstel of overlijden en obductie (indien mogelijk) eindigt her klinische beslissingsproces.

\subsection{Klinisch Spectrum}

Het klinisch spectrum van een bepaald gezondheidsprobleem omvat het totaal aantal patiënten met dat probleem. Het is schematisch weergegeven in de vorm van een half cirkeldiagram in figuur 6.2 .

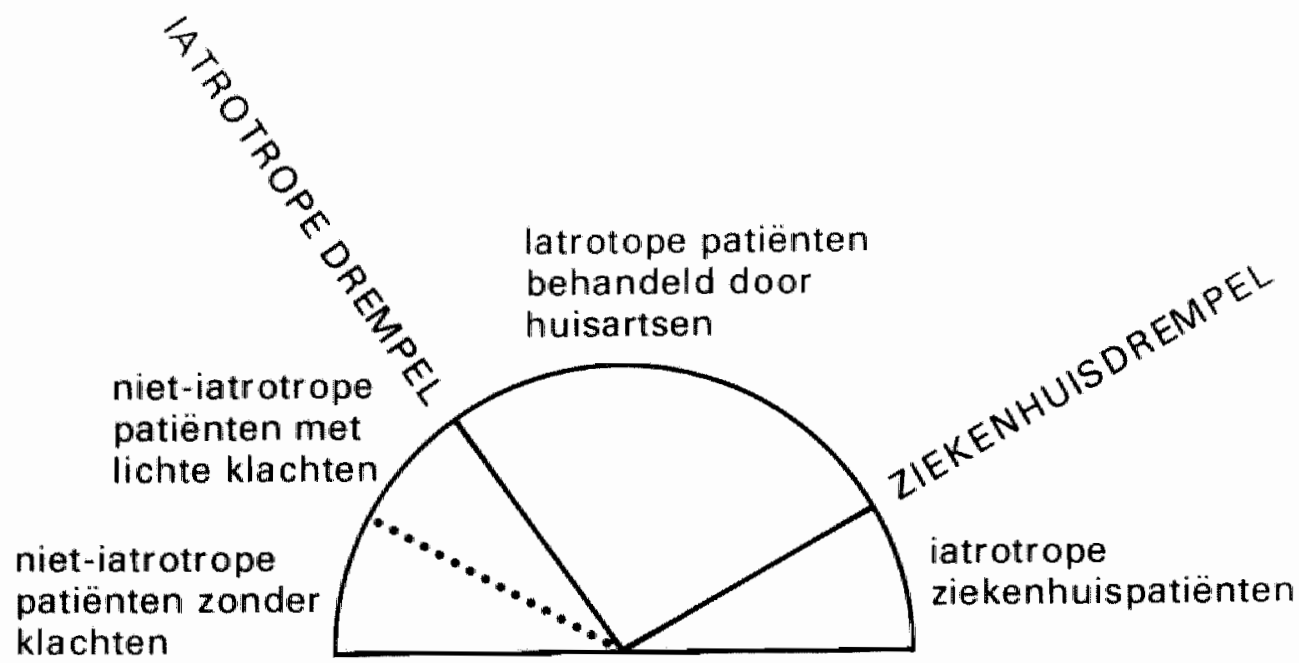

Figuur 6.2

Schematische weergave van het klinisch spectrum.

$(W$ ulff 1980$)$. Iatrotroop $=$ onder behandeling van een arts. 
Het klinisch spectrum valt uiteen in drie hoofdgroepen: niet door een arts behandeld, door een huisarts behandeld, in het ziekenhuis behandeld. Per aparte aandoening varieert de grootte van deze groepen natuurlijk. Appendicitiden komen voor een belangrijk deel in het ziekenhuis terecht, gastritiden bereiken vaak nog niet eens een arts: de patiënten lossen dit probleem zelf op.

Van alle iatrotrope acute buikpijnklachten zou de huisarts volgens De Dombal (1980) $90 \%$ zelf behandelen. Onderzoek naar de grootte van de groep niet-iatrotrope patiënten is in de literatuur niet aangetroffen. Het belang van het klinische spectrum is dat het duidelijk aangeeft dat de door huisartsen behandelde patiënten een totaal andere groep vormen dan de ziekenhuispatiënten. Dit heeft natuurlijk consequenties ten aanzien van de diagnostiek en het te voeren beleid. Een arts met uitsluitend klinische ervaring kan tot andere afwegingen komen als hij patiënten in de algemene praktijk gaat beoordelen.

\subsection{Snelle diagnostiek en de waarde van her-onderzoek}

Niet alleen een zo duidelijk mogelijke diagnose, maar ook zo snel mogelijk uitgevoerde diagnostiek is van groot belang voor de prognose bij patiënten met acute buikpijn (Cope 1979). Het ziektebeeld kan in de tijd snel ten goede of ten kwade veranderen of zelfs snel fataal verlopen. Cope heeft de noodzaak tot snel handelen laten resulteren in een aforisme: "In het algemeen kan worden gesteld dat in de meeste gevallen heftige buikpijn, die optreedt bij patiënten die voordien redelijk gezond waren en die langer dan zes uur aanhoudt, veroorzaakt wordt door aandoeningen waarvoor operatieve behandeling noodzakelijk is". Om wat voor reden dan ook een patiënt met niet opgehelderde acute buikpijn zonder passende instructie of observatie te laten is uit den boze. Her-onderzoek een paar uur later bij twijfel aan de juistheid van de diagnose behoedt een groot aantal patiënten ervoor een aantal dagen later uit het ziekenhuis ontslagen te worden met een litteken op de buik (Angell 1978), en behoedt anderen juist voor een ten onrechte gekozen conservatief beleid. 



\section{Hoofdstuk 7}

\section{ONDERZOEKSMETHODE}

In het nu volgende hoofdstuk worden conceptie, opzet, organisatie en uitvoering van de Acute Buik Analyse aan de orde gesteld: beschreven wordt hoe met het oog op de drieledige doelstelling: analyse van de patiëntenpopulatie, tijdsanalyse en analyse van de gestelde diagnoses, gekozen is voor een prospectief onderzoek via gestructureerde verslaglegging. Beschreven wordt welke artsen meededen aan de Acute Buik Analyse en waar de studie plaatsvond. Verder wordt geschetst hoe de studie verliep, welke veranderingen er achtereenvolgens plaatsvonden en hoe steeds gecontroleerd, gestimuleerd en bijgestuurd moest worden om alles tot een goed einde te brengen. Omwille van de leesbaarheid is bij de beschrijving van de gevolgde methode getracht om de informatie zo veel mogelijk te beperken tot de essenties. Details worden, voor zover relevant, in de hoofdstukken 8,9 en 10 besproken.

\subsection{Soort verslaglegging}

De Acute Buik Analyse is in opzet een prospectief onderzoek waarbij gekozen werd voor gestructureerde verslaglegging. Gestructureerde verslaglegging houdt in dat alle onderzoeksbevindingen worden vastgelegd op voorgedrukte formulieren. Deze manier van benaderen heeft als voordeel dat de items beter en meer systematisch worden ingevuld en (dus) gemakkelijker voor verwerking toegankelijk zijn. Uitgangspunt voor het ontwikkelen van zo'n check-list werd het door het World Congress of Gastro-Enterology (1976/77) gemaakte standaardformulier, dat in diverse onderzoeken (Gunn 1976, Gruer 1977, De Dombal 1980) zijn bruikbaarheid al had bewezen. Het valt op door zijn eenvoud (bijlage 1).

Het uiteindelijk in de Acute Buik Analyse gebruikte formulier is een modificatie hiervan, een wat meer uitgebreide versie, aangepast aan de Maastrichtse situatie. Bijlage 2 toont thet formulier ten behoeve van de huisartsen. Het is op geel papier gedrukt en wordt verder "huisartsenformulier" genoemd.

Bijlagen 3 en $3 a$ laten het formulier voor de specialisten zien. Het is op blauw papier gedrukt en wordt verder "specialistenformulier" genoemd. Naast enkele specifiek bij de verschillende functies behorende zaken als visite, opname en dergelijke is er in principe tussen de formulieren geen enkel verschil.

Het huisartsenformulier heeft twee doorslagen. De eerste vermeldt uitsluitend de differentiaaldiagnose en is bedoeld voor de specialist. Het belang van de patiënt eiste immers dat de door de huisarts gestelde diagnose zo snel mogelijk ter kennis kwam van de arts op de EHBO. De tweede doorslag is ten behoeve van de status van de huisarts zelf.

Het specialistenformulier heeft maar één doorslag. Deze belandde tenslotte in de ziekenhuisstatus.

De oorspronkelijke gele en blauwe formulieren werden gebruikt ten behoeve van de Acute Buik Analyse. De route die de formulieren wolgden en hun eindbestemming zijn schematisch weergegeven in figuur 7.1. 
patient

acute buikpijn

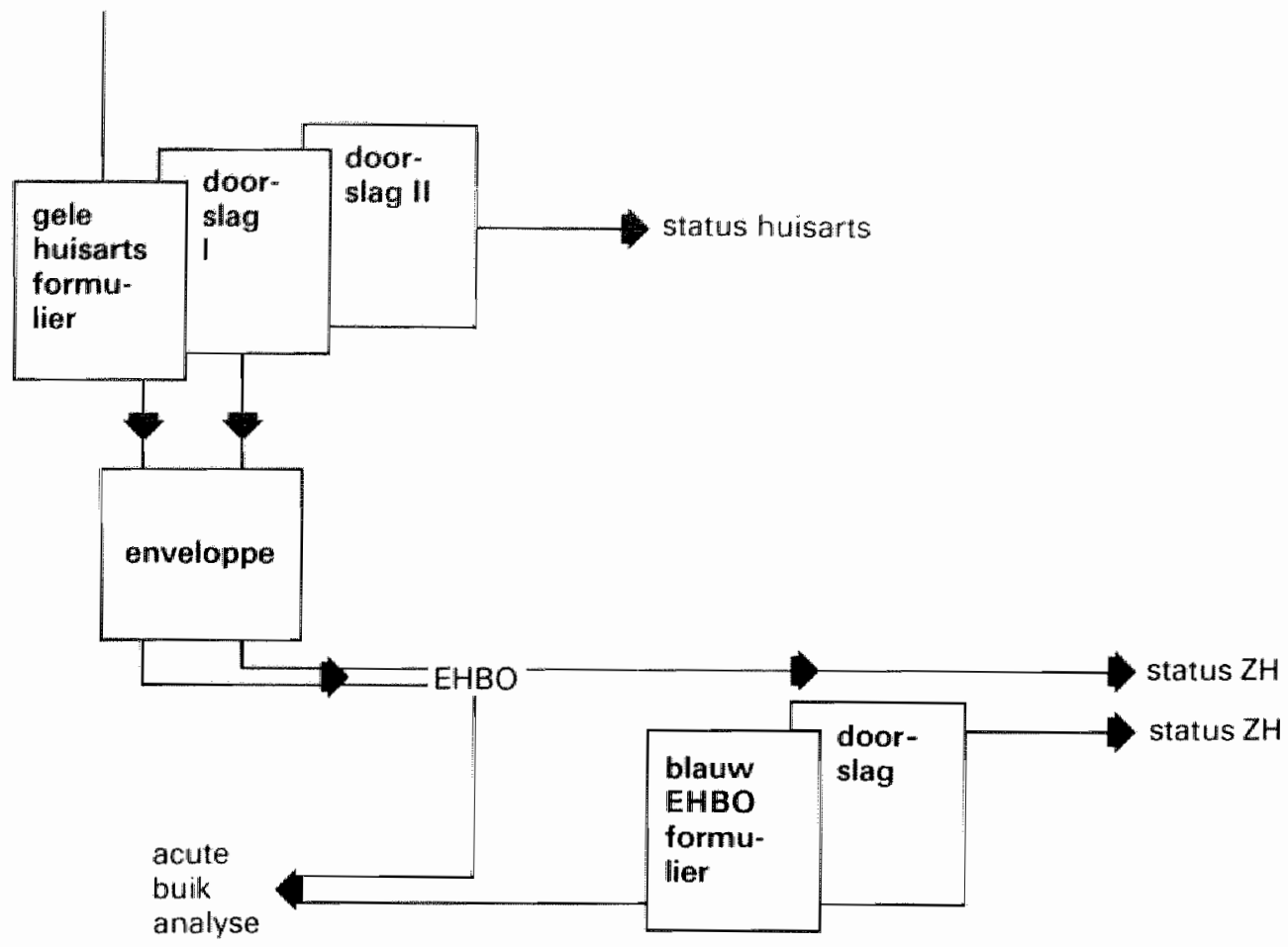

Figuur 7.1

Schematische weergave van de route van de formulieren.

\subsection{Participerende artsen, regio Maastricht}

Tot deelneming aan de Acute Buik Analyse werden de specialismen Algemene Heelkunde, Interne Geneeskunde, Gynaecologie/Obstetrie en Paediatrie van het Academisch Ziekenhuis Maastricht en zeventig huisartsen, die hun patiënten voor een belangrijk gedeelte naar Maastricht verwezen, uitgenodigd. Alle specialismen en vijfenzestig huisartsen zegden hun medewerking toe.

Het arbeidsterrein van de Acute Buik Analyse was geografisch beperkt tot de stad Maastricht en de haar omringende gemeenten, voor zover hun inwoners door hun huisarts voor een belangrijk gedeelte verwezen werden naar het Academisch Ziekenhuis Maastricht. Dit ziekenhuis is het enige in de regio Maastricht. De geografische situatie is weergegeven in figuur 7.2 . 


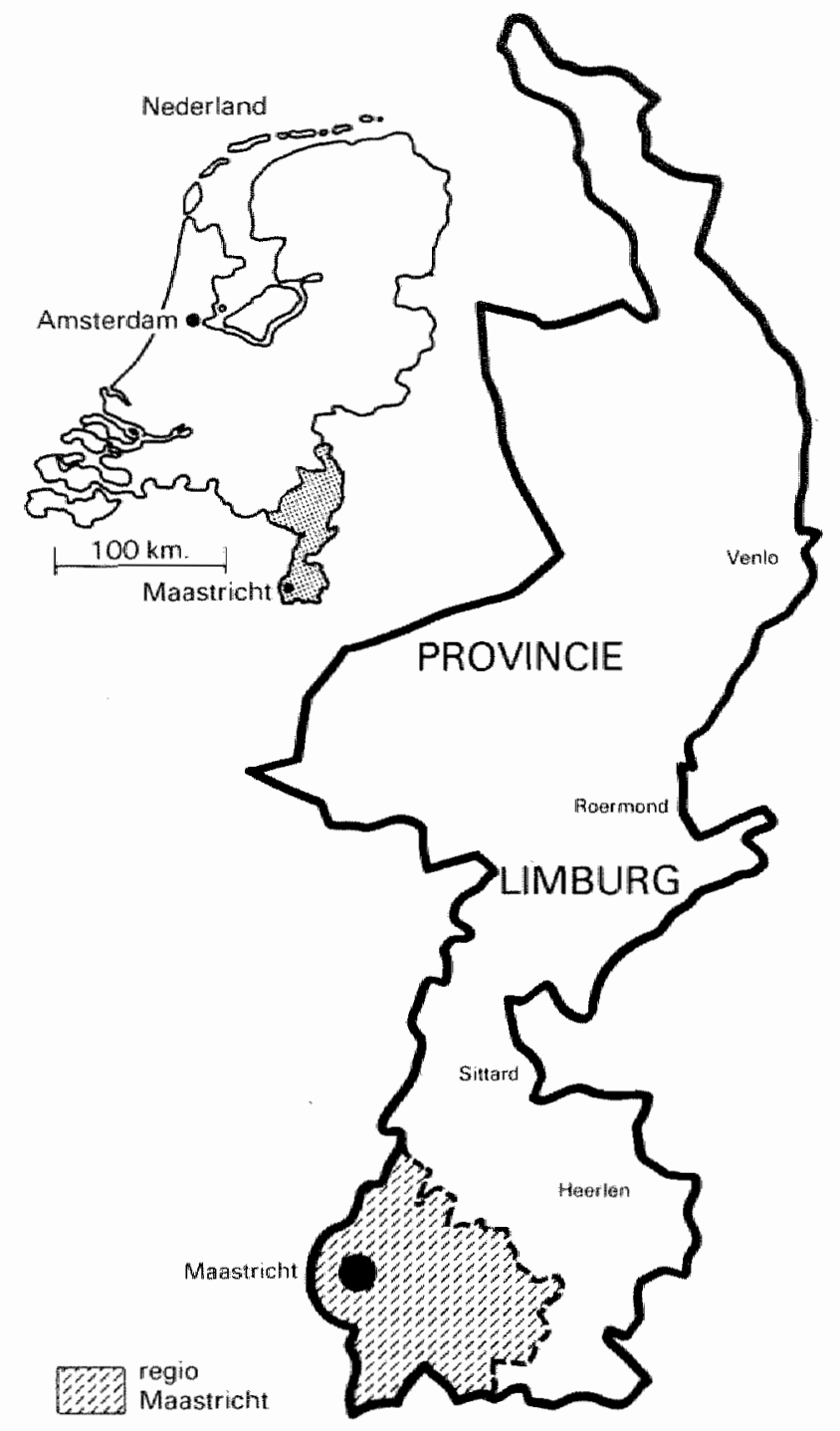

Figuur 7.2

Regio Maasuricht. Gegevens: Planologische Dienst Provincie Limburg.

Op 31 decenber 1983, ten tijde van de dataverzameling was het aantal inwoners van de regio Mastrich 181.616. Op diezelfde datum telde het Academisch Ziekenhuis Maastricht 768 bedden.

\subsection{Verloop van de Acute Buik Analyse}

Na de ontwikkeling van de check-lists en het oriënterend onderzoek naar de medewerkingsbereidheid van specialisten en huisartsen werd een pilot-study gedaan in samenwerking met de afdeling Algemene Heelkunde en acht huisartsen, gedurende de periode 1-7-1982 tot en met 30-9-1982. De formulieren bleken in alle opzichten goed te functione- 
ren: ze werden door alle medewerkers acceptabel gevonden, werden over het algemeen correct en zonder veel problemen ingevuld en volgden de geplande route (figuur 7.1) zonder moeite. Besloten werd dan ook om over te gaan tot uitvoering van de Acute Buik Analyse in zijn oorspronkelijke opzet: met vier ziekenhuisafdelingen en vijfenzestig huisartsen.

De deelnemende huisartsen vulden een onderzoeksformulier in bij elke spoedverwijzing van een patiënt met buikpiin (ongeacht causa of duur) naar thet Academisch Ziekenhuis Maastricht.

De specialisten kregen als opdracht een formulier in te vullen bij elke spoed-confrontatie met een patiënt met acute buikpijn.

De differentiaaldiagnose moest gesteld worden naar aflopende graad van waarschijnlijkheid. De mate van waarschijnlijkheid hoefde niet te worden geschat.

Het onderzoek startte officieël op 1-11-1982.

De EHBO en andere locaties waarnaar de casus zouden worden werwezen fungeerden als meet- en controlepunten. Twee maal per week werd daar ter plekke door de onderzoeker de voortgang van de Acute Buik Analyse gepeild. Aan elk niet, of niet correct ingevuld formulier werd gerappelleerd. Huisartsen werden bij in-gebreke-blijven uiterlijk binnen twee dagen na verwijzing telefonisch door de onderzoeker geraadpleegd over de reden hiervan en over de door hen gestelde verwijsdiagnose. Niet alleen werd op deze wijze toch nog relevante informatie verkregen, maar ook had dit beleid een sterk stimulerend effect.

Erg jammer was dat de meet- en controlepunten op de afdelingen niet adequaat bleken te kunnen functioneren. De onderzoekslocaties varieerden zodanig dat geen overzicht verkregen kon worden over het totaal aantal daar onderzochte patiënten. Omdat gynaecologie/verloskunde en paediatrie al hun patiënten met acute buikklachten direct op de diverse afdelingen onderzochten, zijn deze casus verloren gegaan voor de Acute Buik Analyse. Op de chirurgische, interne en urologische poliklinieken en afdelingen werden geen patiënten met acute buikklachten, die met spoed waren verwezen, in eerste instantie onderzocht . Op de EHBO daarentegen liep alles volgens plan.

Bij het van start gaan van het onderzoek wilden vijfenzestig, in de regio Maastricht gevestigde, huisartsen meewerken aan het onderzoek. Drie huisartsen hadden een vaste huisarts-assistent en verder functioneerde er een aantal arts-assistenten in opleiding. Gedurende de onderzoeksperiode veranderden deze aantallen natuurlijk; twee participerende huisartsen legden hun praktijken neer en er vonden zeven nieuwe vestigingen plaats. Van deze nieuwe vestigingen sloten er drie zich niet aan bij de Acute Buik Analyse omdat ze teveel beslommeringen hadden met hun nieuwe praktijken. Per saldo hebben dus 72 gekwalificeerde huisartsen aan het hele of aan een gedeelte van het onderzoek meegedaan (verwiizingen door de arts-assistent-in-opleiding zijn geacht door hun opleider te zijn gedaan). 
Na negentien maanden looptijd, op 31-5-1984, werd de Acute Buik Analyse gesloten voor nieuwe casus. Er was op dat moment een onderzoekspopulatie beschikbaar van 1100 gevallen met acute buikpijn, een populatie die groot genoeg werd bevonden voor zinvolle verwerking.

In een later stadium, na therapie en ontslag/overlijden, werden de gegevens over het verloop en de einddiagnose van de casus in de Acute Buik Analyse genoteerd vanuit het medisch archief (in paragraaf 8.7 wordt uitglegd wat onder het begrip "einddiagnose" wordt verstaan). Het verzamelen van deze laatste noodzakelijke gegevens door de auteur, heeft anderhalf jaar geduurd.

Tenslotte nog enkele opmerkingen.

Over de casus waarvoor de huisartsen spoedverwijzing niet noodzakelijk vonden is in de Acute Buik Analyse geen informatie. Een poging die te verkriigen is wel gedaan, maar mislukte door een te geringe respons.

De in hoofdstuk 1 genoemde doelstellingen beperken zich vooral tot beschrijvende gegevens ten aanzien van gevallen van acute buikpijn. Daarom is ook de gegevensverwerking beschrijvend van aard waarbij in de tabellen, figuren en bijlagen vooral frequentieverdelingen van de totale populatie en de subgroepen zijn vergeleken. Omdat alle in de Acute Buik Analyse beoordeelde gevallen bovendien behoorden tot een totale populatie en er geen steekproef is getrokken, is er voor gekozen om geen statistische toetsing te verrichten. 


\section{Hoofdstuk 8}

\section{PATIËNTENPOPULATIE}

\subsection{Inleiding}

Dit hoofdstuk is primair gericht op de eerste doelstelling van de Acute Buik Analyse: - analyse van de patiëntenpopulatie en het verloop van de casus tot aan de einddiagnose. Om aan deze doelstelling te kunnen voldoen wordt de gang van zaken rond een casus zo gedetailleerd mogelijk beschreven, vanaf de eerste hulpvraag aan de arts tot aan de einddiagnose. Zo wordt onder andere vastgesteld welke specialismen erbij betrokken waren, hoe vaak er wel en niet tot opname in het ziekenhuis werd besloten, hoe de geslachts- en leeftijdsopbouw was, hoe dit alles zich verhield tot de einddiagnose enzovoort. Op deze wijze werd een totaalowerzicht verkregen van de opbouw van de onderzoekspopulatie en wat er mee gebeurde.

Omdat de casus niet altijd door aan het onderzoek deelnemende huisartsen werden verwezen (maar ook door verpleeghuisartsen, specialisten in hun vrije tijd, enzovoort) en tevens omdat de huisartsen niet altijd een huisartsenformulier (correct) invulden bij verwijzing, zijn binnen de totale onderzoekspopulatie op grond hiervan aparte groepen geformeerd (figuur 8.1). Twee groepen kriigen speciale aandacht en wel de groep die door de aan de Acute Buik Analyse participerende huisartsen naar de EHBO werd verwezen en waarbij de verslaglegging correct was en de groep die zich, buiten elke arts om, op eigen initiatief met buikklachten voor onderzoek op de EHBO van het Academisch Ziekenhuis Maastricht meldde. De einddiagnoses binnen deze laatste groep, die verder "zelfverwijzers" is genoemd, worden vergeleken met die binnen de eerste groep.

Tenslotte krijgen de begrippen (spoed)visite, (spoed)consult en waarneming binnen het huisartsgeneeskundig handelen de aandacht. Uitgelegd wordt wat onder deze begrippen verstaan moet worden en hoe de frequentieverdelingen ervan gerelateerd zijn aan de einddiagnose.

Een belangriik gegeven, dat beslist niet onvermeld kan blijven, is dat uit onderzoek is gebleken dat toepassing van gestructureerde verslaglegging, het gebruik van voorbedrukte formulieren, niet alleen de diagnostiek werbeterde maar ook het te voeren belleid beïnvloedde: het percentage opnames in het onderzoek van Gunn (1976) daalde van 81\% naar $75 \%$, het percentage laparotomieën daalde van $20 \%$ naar $7 \%$; het percentage casus dat na eenmalig onderzoek op de Accident and Emergency Unit retour werd gestuurd naar de huisarts steeg van $16 \%$ naar $34 \%$. Over de invloed van gestructureerde verslaglegging op de beslissing van de huisarts: wel of niet verwijzen, is geen literatuur aangetroffen. Het is aannemelijk dat het aantal verwijzingen erdoor vermindert. Op grond van de cijfers van Gunn moet dan ook gerealiseerd worden dat de in dit hoofdstuk geschetste resultaten anders zouden kunnen zijn dan gebruikelijk. Zonder gestructureerde verslaglegging zouden er waarschijnlijk meer patiënten naar het ziekenhuis zijn verwezen, zouden er meer opnames zijn geweest, zouden er minder terugverwijzingen naar de huisarts hebben plaatsgevonden en zou er vaker geopereerd zijn. 


\subsection{Stroom van de onderzoekspopulatie}

Gedurende de onderzoeksperiode (1-11-1982 tot 31-5-1984) werden 1100 casus met acute buikpijn op de EHBO van het Academisch Ziekenhuis Maastricht onderzocht. Met nadruk wordt gesproken over casus en niet over patiënten. Deze twee begrippen zijn niet synoniem: 34 patiënten meldden zich meer dan één keer met acute buikklachten op de EHBO (Bijlage 4). Er waren in totaal 1040 patiënten. Onafhankelijk van oorzaak of duur van de klachten zijn alle gevallen van buikpijn die zich op de EHBO meldden in de Acute Buik Analyse opgenomen en samengevoegd tot de totale onderzoekspopulatie.

In het kader van de doelstelling verdient een analyse op basis van casus de voorkeur boven die van patiënten.

Welke wegen de casus in principe gevolgd zouden kunnen hebben via huisarts, EHBO enzovoort is schematisch weergegeven in figuur 8.1.

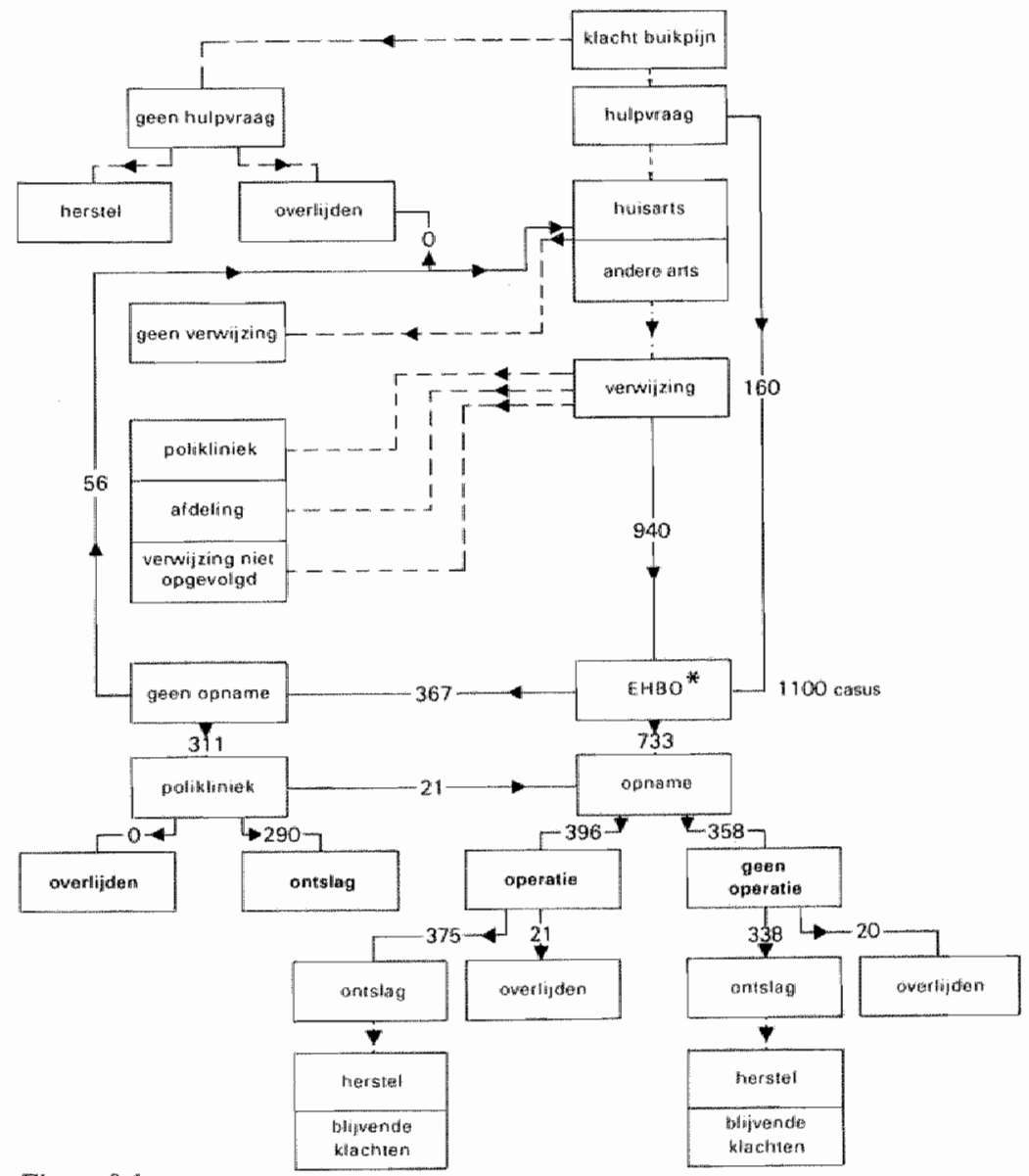

Figuur 8.1

Roure acute buikpijn. Totale populatie $(\mathrm{n}=1100)$

-- : niet in Acute Buik Analyse gemeten patiëntenstroom

_... : wel gemeten patiëntenstroom.

* :meet-en controlepunt. 
Uit figuur 8.1 blijkt dat slechts een deel van alle mogelijke routes waarlangs een geval van acute buikpijn kan gaan in de Acute Buik Analyse is bestudeerd. Het is waarschijnlijk dat zich via de bestudeerde wegen juist de meest ernstige buikpathologie moet hebben bewogen. Figuur 8. I wordt in de volgende paragrafen chronologisch besproken: te beginnen bij de verwijzing en eindigend bij ontslag of overlijden.

\subsection{Verwijzing, zelfverwijzing, indeling van de totale populatie in groepen.}

Uit figuur 8.1 blijkt dat niet de gehele patiëntenstroom naar de EHBO toe via een arts is gelopen: 160 casus gingen buiten hun verantwoordelijkheid om. De resterende 940 casus zijn niet alleen door de aan het onderzoek participerende huisartsen verwezen, maar ook door andere huisartsen, verpleeghuisartsen, specialisten in hun vrije tijd enzovoort. Ook hebben de deelnemende artsen het huisartsenformulier niet altijd volgens afspraak ingevuld,

Op grond van deze feiten is de totale onderzoekspopulatie dan ook ingedeeld in vijf groepen: A, B, C, D en E. Een weergave hiervan is te zien in figuur 8.2.

Volledigheidshalve is in figuur 8.2 per groep tevens aangegeven in hoeveel gevallen verwezen werd door de eigen huisarts en hoe vaak tijdens waarneming. In het kort worden de vijf groepen achtereenvolgens gekarakteriseerd:

\section{Groep A (zelfverwijzers)}

Groep A telt 160 casus die zich op eigen initiatief, of op dat wan hun omgeving, buiten verantwoordelijkheid van een arts, met acute buikpijn voor onderzoek op de $\mathrm{EHBO}$ van het Academisch Ziekenhuis Maastricht hebben gemeld. Deze EHBO is een zogenaamde "open EHBO", wat zeggen wil dat iedereen die er zich met klachten meldt behandeld wordt. Filosofie hierbij is dat het risico op calamiteiten zo klein mogelijk dient te zijn: het niet beantwoorden van een hulpvraag heeft onaanvaardbare risico's. Bij een "gesloten EHBO", waar uitsluitend behandeld wordt na verwijzing door een arts, zou groep A niet hebben bestaan of vele malen kleiner zijn geweest. Aan het einde van dit hoofdstuk, in paragraaf 8.10 komt groep A uitgebreid aan de orde.

Groep B (verwijzer geen huisarts)

De 31 casus, behorende tot groep B zijn verwezen door andere artsen dan huisartsen: drie gevallen werden verwezen vanuit een psychiatrische kliniek, zes vanuit een verpleeginrichting en tweeèntwintig door andere artsen (specialisten, specialisten in opleiding, GGD-artsen, enzovoort). Omdat adequate informatie over deze verwijzingen ontbreekt blijft groep B als aparte groep verder buiten beschouwing. Alleen daar waar gegevens over de totale populatie worden verstrekt zijn ook de gegevens van groep B toegevoegd.

Groep C (niet aan de Acute Buik Analyse participerende huisartsen)

De huisartsen die niet aan de Acute Buik Analyse deelnamen stuurden samen 53 casus in. Ook hier is geen adequate informatie aanwezig over de motieven die leidden tot verwijzing. Ook groep $\mathrm{C}$ blijft buiten beschouwing als aparte groep. Alleen daar waar gegevens over de totale populatie en over het totale aantal door huisartsen verwezen casus worden verstrekt zijn ook de gegevens van groep $\mathrm{C}$ toegevoegd. 
160: zelfverwijzers, groep A

31: verwijgend arts geen thuisarts, groep B

53: met spoed verwezen door niet asn het onderzoek participerend huisertis, groep C

292: met spaed verwezen door een huisarts, participerend aan het onderzoek maar niet woorzien wan een correct ingevuld huisartsformulier, groep D

564: gevallen die gedurende de periode $1.11-1982 \mathrm{t} / \mathrm{m} 31.5 .1984$ wegens acute buikpinn met spoed naar de EHBO zjin verwezen door een aan het onderzoek participerend huisarts en voorzien van een correct ingevuld huisartsenformulier. groep E
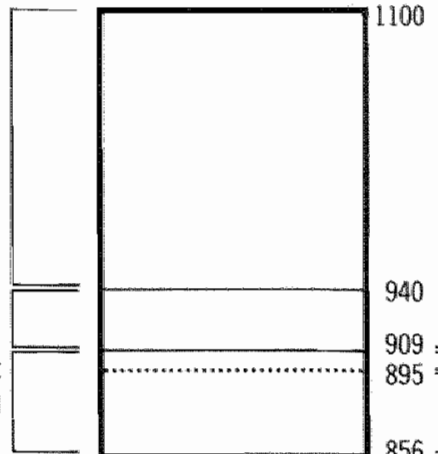

940

909

895

856

783

564

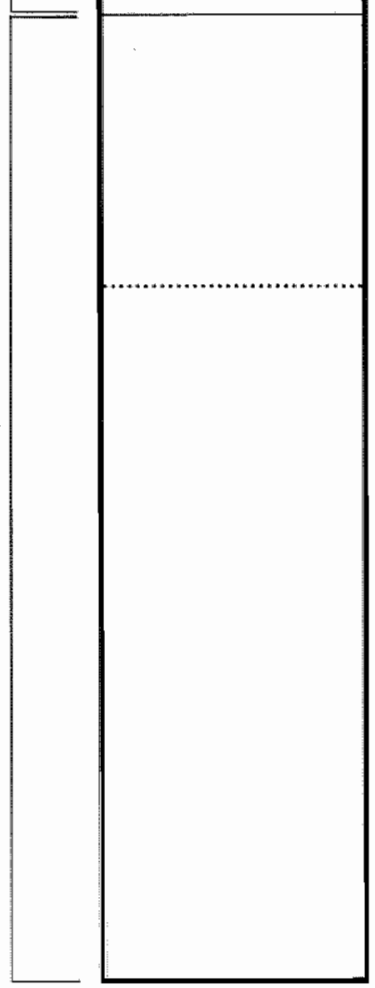

0
1100: alle casus dlie gedurende periode $111.1962 \mathrm{t} / \mathrm{m}$ 31.5-1984 werens acute buikpinn op de EHBO zing onderzocht: Verder te noemen: totale populatie. 7il zijn allen woorzien van een correct ingevald speciabister. formultier

14: tijdens waaneming werwezen

39: door eigen huisarts verwezen

73: tijdens watneming verwezen

219: door eigen huisarts verwezen

151: tijdens waarneming verwezen
413: door eigen huisarts werwezen

Fïguur 8.2

Alle casus die gedurende de periode 1-11-1982 $\mathrm{t} / \mathrm{m}$ 31-5-1984 wegens acute builkpijn op de EHBO van ber Academisch Ziekenhuis Maastricht werden onderzocht. 
Groep $\mathbf{D}$ (huisartsenverwijzing zonder formulier)

Groep D, 292 casus, is verwezen door aan de Acute Buik Analyse participerende huisartsen, maar is verder niet voorzien van een correct ingevuld huisartsenformulier. In de meeste gevallen ontbrak dit volledig, in de overige (10) gevallen was het formulier niet bruikbaar. De redenen van niet of onvolledig invullen waren: pure nalatigheid (in 73 gevallen werd door de betrokken huisarts toegegeven dat hij eigenlijk het huisartsenformulier volledig had moeten invullen) en het niet in eerste instantie denken aan een "acute buik" (medebeoordeling door een specialist: $200 \mathrm{x}$, verwijzing op sociale indicatie: $6 \mathrm{x}$, op speciaal verzoek van de patiënt: $13 x$ ). Bij alle verwijzingen op sociale indicatie en op speciaal verzoek van de patiënt bleken achteraf geen objectieve afwijkingen te zijn vastgesteld.

Binnen groep D zijn de verwijsdiagnoses, en naar welk specialisme er verwezen werd, door telefonisch informeren achteraf door de onderzoeker, uiterlijk binnen twee dagen na verwijzing bekend geworden.

De gegevens uit groep D zijn alleen daar toegevoegd, waar informatie wordt verstrekt over de totale populatie en over het aantal door (al dan niet aan de Acute Buik Analyse participerende) huisartsen verwezen casus.

Groep $\mathbf{E}$ (huisartsverwijzing met correct ingevuld formulier)

In groep E is alle in de Acute Buik Analyse gewenste informatie aanwezig omdat zowel de huisartsenformulieren als de specialistenformulieren (die overigens in de vorige groepen ook correct ingevuld aanwezig waren) op de juiste wijze werden ingevuld. Hierdoor is groep E de meest volledige. Zij telt 564 casus, $65,9 \%$ van alle casus die door de aan het onderzoek deelnemende huisartsen naar de EHBO werden verwezen. 


\subsection{Onderzoekende specialismen op de EHBO}

$\mathrm{Na}$ het verzamelen van de noodzakelijke gegevens en de daarop volgende diagnostische beslissing van de huisarts is in een aantal gevallen overgegaan tot verwijzing naar de EHBO (figuur 8.1). Er werd daarbij in de meeste gevallen gericht naar een bepaald specialisme verwezen (groep $\mathrm{D}$ en $\mathrm{E}$ ). Over naar wellke specialismen de patiënten behorende tot de groepen $B$ en $C$ werden verwezen is niet voldoende informatie beschikbar. Bij de zelfverwijzers (groep A) is aan de hand van de problematiek op de EHBO bepaald welk specialisme primair zou gaan behandelen. In hoeverre de patiënt zelf hierin een stem heeft gehad is niet bekend. Tabel 8.3 laat de aantallen en percentages zien:

Tabel 8.3

Onderzoekend specialisme op de EHBO. Groep A versus groep D en E.

\begin{tabular}{lll}
\hline $\begin{array}{l}\text { Specialisme op } \\
\text { de EHBO }\end{array}$ & $\begin{array}{l}\text { Groep A (zelfver- } \\
\text { wijzers) }\end{array}$ & $\begin{array}{l}\text { Groep D en E } \\
\text { door een aan het onderzoek } \\
\text { deelnemende huisarts verwezen }\end{array}$ \\
\hline Aantal (\%) & Aantal $(\%)$ \\
Chirurgie & $132(82,5)$ & $632(73,8)$ \\
Interne Geneesk. & $28(17,5)$ & $219(25,6)$ \\
Gynaecologie & -- & $4(0,5)^{\star}$ \\
Urologie & -- & $1(0,1)$ \\
\hline Totaal & $160(100)$ & $856(100)$ \\
\hline
\end{tabular}

* gynaccologie niet opgenomen in de Acute Buik Analyse.

In welke mate er op de EHBO intercollegiaal is geconsulteerd en hoe vaak er daarna intern is doorverwezen naar een ander specialisme is niet bekend.

Onmiddellijk na het beantwoorden van de vraag naar welk specialisme de huisartsen hun patiënten doorverwezen komt de vraag naar voren: welke waren de redenen hiervoor, wat bewoog de desbetreffende huisarts, valt dit af te leiden uit de diagnose? Het antwoord hierop is niet eenvoudig. Een waarschijnlijkheidsdiagnose komt in een onbekend aantal gevallen niet uitsluitend op puur medische gronden tot stand (hoofdstuk 10): ook andere factoren als sociale indicatie, druk door de patiënt op de arts uitgeoefend om verwezen te worden ("opwaartse druk") enzovoort, kunnen een diagnose kleuren. Desondanks moet de verwijsdiagnose over het algemeen toch als een belangrijke maatstaf voor de reden van verwijzen worden beschouwd. Tabel 8.4 laat zien onder welke diagnoses de huisartsen hun patiënten naar de EHBO verwezen en naar welke specialismen: 
Tabel 8.4

Frequentieverdeling van de verwijsdiagnoses, uitgesplitst per specialisme waarnaar verwezen werd. Groep D en E.

\begin{tabular}{lrrrrr}
\hline Verwijsdiagnose & Chirurg & Internist & Gynaecoloog & Uroloog & Totaal \\
\hline Non Spec.Abd.Pain & 78 & 87 & - & - & 165 \\
Appendicitis acuta & 255 & 1 & - & - & 256 \\
Append.infiltraat & 18 & - & - & - & 18 \\
Cholecystitis acuta & 39 & 2 & - & - & 41 \\
Cholecystitis chronica & 29 & 4 & - & - & 33 \\
Obstructie dunne darm & 26 & 2 & - & - & 28 \\
Perforatie ulcus pept. & 35 & 3 & - & - & 38 \\
Pancreatitis & 21 & 14 & - & - & 35 \\
Diverticulitis & 12 & 4 & - & - & 16 \\
Urolithiasis & 17 & - & - & 1 & 18 \\
Vasculaire aandoening & 10 & 1 & - & - & 11 \\
Gynaecologische afw. & 15 & - & 4 & - & 19 \\
Maligniteit & 4 & 9 & - & - & 13 \\
Overige diagnoses $\star$ & 73 & 92 & - & - & 165 \\
& & & & & 856 \\
\hline Total aantal & 632 & 219 & 4 & 1 & 8 \\
\end{tabular}

* Wat het begrip Non Specific Abdominal Pain exact inhoudt wordt werduidelijkt in paragraaf 8.12.2.

* zje bijlage 13 om een indruk te krijgen van de zeer gevarieërde samenstelling van deze categorie.

De in tabel 8.4 genoemde verwijsdiagnoses zijn de eerstgenoemde van de differentiaaldiagnoses, de diagnoses met de hoogste graad van waarschijnlijkheid conform de instructie (hoodstuk 7). De meeste gevallen zijn bij de chirurg terechtgekomen. De casus appendicitis acuta, cholecystitis acuta en vasculaire aandoening die in eerste instantie naar de internist werden verwezen waren zeer onzekere diagnoses, waarbij de internist verzocht werd tot het geven van een mede-oordeel. Uitsplitsing van de verwijsdiagnoses in groep D en $\mathrm{E}$ afzonderlijk is te zien in bijlage 21. De bij de verwijsdiagnose in tabel 8.4 horende einddiagnoses zijn te vinden in de bijlagen 5 en 20 .

\subsection{Beleid EHBO}

Uit figuur 8.1 bleek dat na presentatie op de EHBO en na de daar genomen diagnostische beslissing er drie dingen met een patiënt met acute buikpijn konden gebeuren:

1. onmiddellijke opname voor verdere diagnostiek of (operatieve)therapie;

2. geen opname maar poliklinische controle; de patiënt krijgt bij het verlaten van de EHBO tevens de instructie direct terug te komen bij verergering van de klacht;

3. geen opname maar verdere controle door de huisarts of zijn plaatsvervanger: deze wordt natuurlijk zo snel mogelijk over de casus ingelicht. 
Tabel 8.5 drukt dit in getal en percentage uit:

Tabel 8.5

Beleid op de EHBO. Totale populatie.

\begin{tabular}{lc}
\hline Beleid & Aantal $(\%)$ \\
\hline Opname ziekenhuis & $733(66,6)$ \\
Poliklinische controle & $311(28,3)$ \\
Controle door huisarts & $56(5,1)$ \\
\hline Totaal & $1100(100)$ \\
\hline
\end{tabular}

Tweederde van de op de EHBO gepresenteerde gevallen van acute buikpijn imponeerde als zo ernstig dat tot onmiddellijke opname werd overgegaan.

Zoals bij het verwijsbeleid door de huisartsen de vraag gesteld is waarom hij verwees, wordt een soortgelijke vraag gesteld ten aanzien van het beleid op de EHBO. Een maatstaf om de reden van opname enzovoort te bepalen is de op de EHBO gestelde diagnose.

Vermeld moet worden dat deze diagnose niet altijd tot stand kwam na onderzoek door één arts. Vaak, in welke mate is onbekend, was de diagnose die op het specialistenformulier werd vermeld het resultaat van de besluitvorming door verschillende artsen (jongste assistent, chef de clinique, andere specialist enzovoort). Tabel 8.6 geeft het beleid weer bij de diverse gestelde diagnoses op de EHBO:

Tabel 8.6

Op de EHBO gestelde diagnose en het bijbehorende beleid.

Totale populatie.

\begin{tabular}{|c|c|c|c|c|}
\hline $\begin{array}{l}\text { Opde EHBO gestelde } \\
\text { diagnose }\end{array}$ & $\begin{array}{l}\text { Opname } \\
\text { polikliniek }\end{array}$ & $\begin{array}{l}\text { Controle } \\
\text { huisarts }\end{array}$ & $\begin{array}{l}\text { Retour } \\
\text { huisarts }\end{array}$ & Totaal \\
\hline Non Specif. Abd. Pain & 16 & $\left.218^{\star}\right)$ & 48 & 282 \\
\hline Appendicitis acuta & 199 & 19 & - & 218 \\
\hline Appendiculair infilt. & 18 & 3 & - & 21 \\
\hline Cholecystitis acuta & 32 & - & - & 32 \\
\hline Cholecystitis chronica & 35 & - & - & 35 \\
\hline Obstructie dunne darm & 25 & $1 \star \star)$ & $\left.l^{\star \star}\right)$ & 27 \\
\hline Perforatie ulcus pept. & 28 & - & - & 28 \\
\hline Pancreatitis & 46 & - & - & 46 \\
\hline Diverticulitis & 15 & 1 & - & 16 \\
\hline Urolithiasis & 15 & 33 & 7 & 55 \\
\hline Vasculaire aandoening & 14 & - & - & 14 \\
\hline Gynaecologische afw. & 28 & 19 & - & 47 \\
\hline Maligniteit & 20 & - & - & 20 \\
\hline Overige diagnoses & 242 & 17 & - & 259 \\
\hline Totaal aantal & 733 & 311 & 56 & 1100 \\
\hline
\end{tabular}


De groep "overige diagnoses" is de grootste en is zeer gevarieerd van samenstelling (voor een indruk zie bijlage 13).

De in tabel 8.6 genoemde op de EHBO gestelde diagnoses zijn de eerste van de differentiaaldiagnoses, die met de hoogste graad van waarschijnlijkheid in de ogen van de onderzoekende arts, conform de instructie die hij bij de start van de Acute Buik Analyse had gekregen (hoofdstuk 7).

Opvallend in tabel 8.6 is dat de opgenomen casus bijna allemaal een anatomisch gedefiniêterde diagnose kregen. De niet opgenomen casus werden in de meeste gevallen door een klachtendiagnose gekarakteriseerd (Non Specific Abdominal Pain). De bij de op de EHBO gestelde diagnoses horende einddiagnoses zijn te zien in bijlage 6 . Van de casus die ter controle op de poliklinieken waren terugbesteld zijn er later nog vanuit de chirurgische polikliniek 21 opgenomen (tabel 8.6 en figuur 8.1). Zij waren allen door een huisarts verwezen en werden op de EHBO in eerste instantie als a-specifiek beschouwd. Uiteindelijk bleven er 11 onveranderd van diagnose, 1 ontwikkelde zich tot een appendicitis acuta perforata, 2 bleken een cholecystitis chronica te zijn, 2 waren adnexitis en 1 maligniteit. Verder was er een geval van coprostasis, een urineweginfectie, een diverticulose en een pneumonie. Van de 218 op de EHBO gestelde en poliklinisch gecontroleerde waarschijnlijkheidsdiagnoses Non Specific Abdominal Pain veranderden er uiteindelijk 208 $(95,4 \%)$ niet van diagnose. Op deze laatste bevinding wordt teruggekomen in paragraaf 8.12.1. Het kan bevreemding wekken dat 19 casus onder de mogelijke diagnose appendicitis acuta niet opgenomen werden. Deze casus hadden echter een te geringe graad van waarschijnlijkheid om direct tot opname over te gaan. De ziektebeelden zijn overigens later vanzelf opgeklaard.

\subsection{Follow-up na diagnostische beslissing op de EHBO}

Nadat het op de EHBO bepaalde beleid was geëffectueerd (opname, controle polikliniek, controle door de huisarts) kon er met een patiënt natuurlijk veel gebeuren. Hij kon na al dan niet geopereerd te zijn genezen, er konden zich complicaties voordoen, hij kon na ontslag opnieuw wegens dezelfde klachten worden opgenomen, enzovoort. Van het totaal aantal opgenomen casus zijn er 396 geopereerd (figuur 8.1). Dit is $36 \%$ van de totale in het onderzoek opgenomen populatie. Bij vrijwel alle operaties bleek er achteraf een objectieve afwijking te bestaan (bijlage 7). Slechts bij 29 operaties (7,3\%) bleek geen enkele afwijking aantoonbaar. Van deze 29 operaties bleken er 20 verricht wegens vermoedelijke appendicitis acuta: pathologisch anatomisch bleek de verwijderde appendix zonder afwijkingen. Bij de overige 9 casus werd louter op het klinische beeld, uitsluitend op grond van een klachtendiagnose, een exploratieve laparotomie gedaan: bij 6 kon durante en post operatione geen enkele afwijking worden vastgesteld, bij 2 werd à vue tot de diagnose lymphadenitis mesenterialis besloten (welke pathologisch anatomisch overigens niet kon worden bevestigd) terwijl bij de laatste patiënt na een negatieve bevinding durante operatione later op het zich ontwikkelende klinische beeld de (eveneens op geen enkele objectieve wijze bevestigde) einddiagnose gastritis werd gesteld. 
De heropnames en heronderzoeken na ontslag uit het ziekenhuis of uit poliklinische controle zijn, voorzover zij plaatsvonden gedurende de onderzoeksperiode van de Acute Buik Analyse, via de onderzochte route (figuur 8.1) hierin opgenomen. Natuurlijk is dit aantal niet compleet: er zullen beslist casus na sluiting van de Acute Buik Analyse opnieuw wegens acute buikklachten in het ziekenhuis terecht ziin gekomen. Bijlage 8 geeft weer wat ervan bekend is. De einddiagnoses en de sterfte komen in de volgende paragraaf aan de orde.

\subsection{Einddiagnoses, mortaliteit}

In hoofdstuk 6 (figuur 6.1) is uitgelegd dat na therapie en waarneming van het behandelingsresultaat een einddiagnose wordt gesteld. Als einddiagnose wordt beschouwd die diagnose, waaronder een patiënt uit het ziekenhuis en/of poliklinische controle wordt ontslagen. Er zijn vele mogelijkheden om einddiagnoses te catalogiseren, variërend van een onkritische opsomming van de letterlijk gestelde diagnoses (in dit geval meer dan 100!) tot aan het brengen van groepen letterlijke diagnoses onder één noemer. In de Acute Buik Analyse is gekozen voor die catalogisering, welke in de internationale literatuur gebruikelijk is (Wilson 1979, De Dombal 1980). Reden hiervoor is dat op deze wijze zo vergelijkbaar mogelijk materiaal wordt verkregen. Bij alle categorieën einddiagnoses, behalve bij de categorie Non Specific Abdominal Pain werden objectieve afwijkingen vastgesteld (pathologisch-anatomisch, röntgenologisch, enzovoort), die een aannemelijke verklaring waren voor die einddiagnose. In paragraaf 8.12.2 wordt hierop teruggekomen. Tabel 8.7 laat de indeling in categorieën einddiagnoses zien van de totale onderzoekspopulatie (groep A t/m E):

\section{Tabel 8.7}

Einddiagnoses. Totale populatie.

Einddiagnose

Non Spec. Abd. Pain

Appendicitis

Cholecystitis

Obstructie dunne darm

Geperforeerd ulcus pept.

Pancreatitis

Diverticulitis

Urolithiasis

Overige
Aantal ( $\%)$

$469(42,6)$

$139(12,7)$

$65(5,8)$

$35(3,2)$

$20(1,8)$

$50(4,6)$

$12(1,1)$

$17(1,5)$

$293^{\star}(26,6)$

Totaal

$1100(100)$

\footnotetext{
* Zie bijlage 13.
} 
Uit tabel 8.7 blijkt dat de fractie Non Specific Abdominal Pain numeriek de grootste is. Als aparte diagnose komt appendicitis op de tweede plaats. Hoe de diverse categorieën zijn opgebouwd is te zien in de bijlagen $9,12,13,14,15$ en 45 . Hoe de einddiagnoses zich verhielden tot de door de huisartsen en op de EHBO gestelde diagnoses wordt behandeld in hoofdstuk 10.

Wat de mortaliteit betreft bleek al uit figuur 8.1 dat 41 patiënten tijdens opname zijn overleden maar dat er geen patiënten stierven tijdens poliklinische controles of controle door de huisarts of diens plaatsvervanger (informatie na twee weken verkregen). Tabel 8.8 geeft de mortaliteit weer per categorie einddiagnose:

\section{Tabell 8.8}

Mortaliteit tijdens opname, poliklinische controle en binnen 2 weken na terugverwijzing huisarts per categorie einddiagnoses. Totale populatie.

Einddiagnose $\quad$ Mortaliteit (\%)

Non Specific Abdominal Pain $(n=469)$

$2(0,4)^{\star}$

Appendicitis $(\mathbf{n}=139)$

Cholecystitis $(\mathrm{n}=65)$

Obstructie dunne darm $(\mathrm{n}=35)$

Geperforeerd ulcus pepticum $(n=20)$

Pancreatitis $(\mathrm{n}=50)$

- -

-

Diverticulis $(\mathrm{n}=12)$

$5(14,2)$

$3(15,0)$

$4(8,0)$

$1(8,3)$

Urolithiasis $(\mathrm{n}=17)$

Vasculaire aandoeningen $(n=14)$

Overige diagnoses $(\mathbf{n}=279$ )

Totaal $(n=1100)$

$41(5,4)$

* Het betrof twee bejaarde patiënten, dic door een verpleegk liniek wegens buikklachten met spoed naar de EHBO waren verwezen, daar in shock aankwamen en overleden voordat de diagnostiek rond was. Obductie werd niet toegestan.

De hoogste mortaliteit heeft de categorie vasculaire aandoeningen, gevolgd door de categorieèn geperforeerd ulcus pepticum en obstructie dunne darm. Specificatie van de mortaliteit in geopereerde en niet geopereerde casus is te zien in bijlage 11 .

Tot slot moet vermeld worden dat als er meerdere einddiagnoses mogelijk waren (bijlage 10) er gekozen is voor die categorie waaronder het ziektebeeld zich klinisch presenteerde tijdens opname of poliklinische controle en die tevens durante operatione of pathologisch anatomisch werd bevestigd. 


\subsection{Vergelijking einddiagnoses met internationale bevindingen.}

De opbouw van de totale populatie bij de Acute Buik Analyse is anders dan die van de meeste internationale series. De verschillen zijn:

1. de internationale series zijn gebaseerd op getallen van uirsluitend chirurgische afdelingen; in de Acute Buik Analyse zijn ook andere specialismen bestudeerd (tabel 8.4);

2. buikklachten langer durend dan één week, herniaties en traumata zijn bij de internationale studies buiten beschouwing gelaten;

3. het in de Acute Buik Analyse gebruikte begrip diverticulitis is niet synoniem met het angelsaksische "acute diverticular disease": hieronder valt namelijk eveneens de perforatie als gevolg van een diverticulitis; omdat de symptomatologie essentieel verschillend is (Verschueren 1983) werden in de Maastrichtse studie perforaties ten gevolge van diverticulitis gerangschikt onder de categorie "overige diagnoses";

4. de internationale series zijn gebaseerd op uitsluitend opgenomen casus.

Om tot een vergelijkbare serie te komen zijn 522 casus uitgesloten (bijlage 16). Tabel 8.9 toont de aldus gecorrigeerde Maastrichtse serie in vergelijking tot een serie uit Leeds en tot een grote internationale serie onder auspiciën van het World Congress of Gastro-Enterology 1979 (De Dombal 1980).

Tabel 8.9

Vergelijking serie Acute Buik Analyse met internationale series.

Einddiagnose

\begin{tabular}{|c|c|c|}
\hline $\begin{array}{l}\text { Maastricht } \\
(n=578)\end{array}$ & $\begin{array}{l}\text { Leeds } \\
(\mathrm{n}=552)\end{array}$ & $\begin{array}{l}\text { Internationaal } \\
(\mathrm{n}=6097)\end{array}$ \\
\hline
\end{tabular}

Non Spec. Abd.Pain

$\begin{array}{rrr}26,0 \% & 50,5 \% & 43,0 \% \\ 23,0 \% & 26,3 \% & 24,2 \% \\ 9,3 \% & 7,6 \% & 8,9 \%\end{array}$

Appendicitis

$5,2 \%$

$3,6 \%$

$4,0 \%$

Obstructie dunne darm

$3,5 \%$

$3,1 \%$

$2,8 \%$

Pancreatitis

$5,5 \%$

$2,9 \%$

$2,3 \%$

Diverticulitis

$1,9 \%$

$2,0 \%$

$2,1 \%$

Overige diagnoses

$25,6 \%$

$4,0 \%$

$12,7 \%$

Totaal

$100 \%$

$100 \%$

$100 \%$

Bij de drie vergeleken series is de overeenkomst dat de categorie Non Specific Abdominal Pain steeds de grootste was. 


\subsection{Geslacht, leeftijd}

In deze paragraaf wordt beschreven welke relatie geslacht en leeftijd hebben tot de einddiagnoses. Het mag als algemeen bekend worden verondersteld dat sommige buikaandoeningen voorkeur hebben voor geslacht of voor een bepaalde leeftijdsgroep. Zo zouden galstenen in hoofdzaak voorkomen bij vrouwen tussen de 60 en 70 jaar (De Dombal 1980), pancreatitis acuta zou een leeftijdspiek hebben tussen de 30 en 40 jaar (meer bij mannen dan bij vrouwen) en een tweede piek tussen de $50 \mathrm{en} 60$ jaar (meer bij vrouwen dan bij mannen). In figuur 8.10 is te zien hoe de leeftijds- en geslachtsverdeling in de Acute Buik Analyse was:

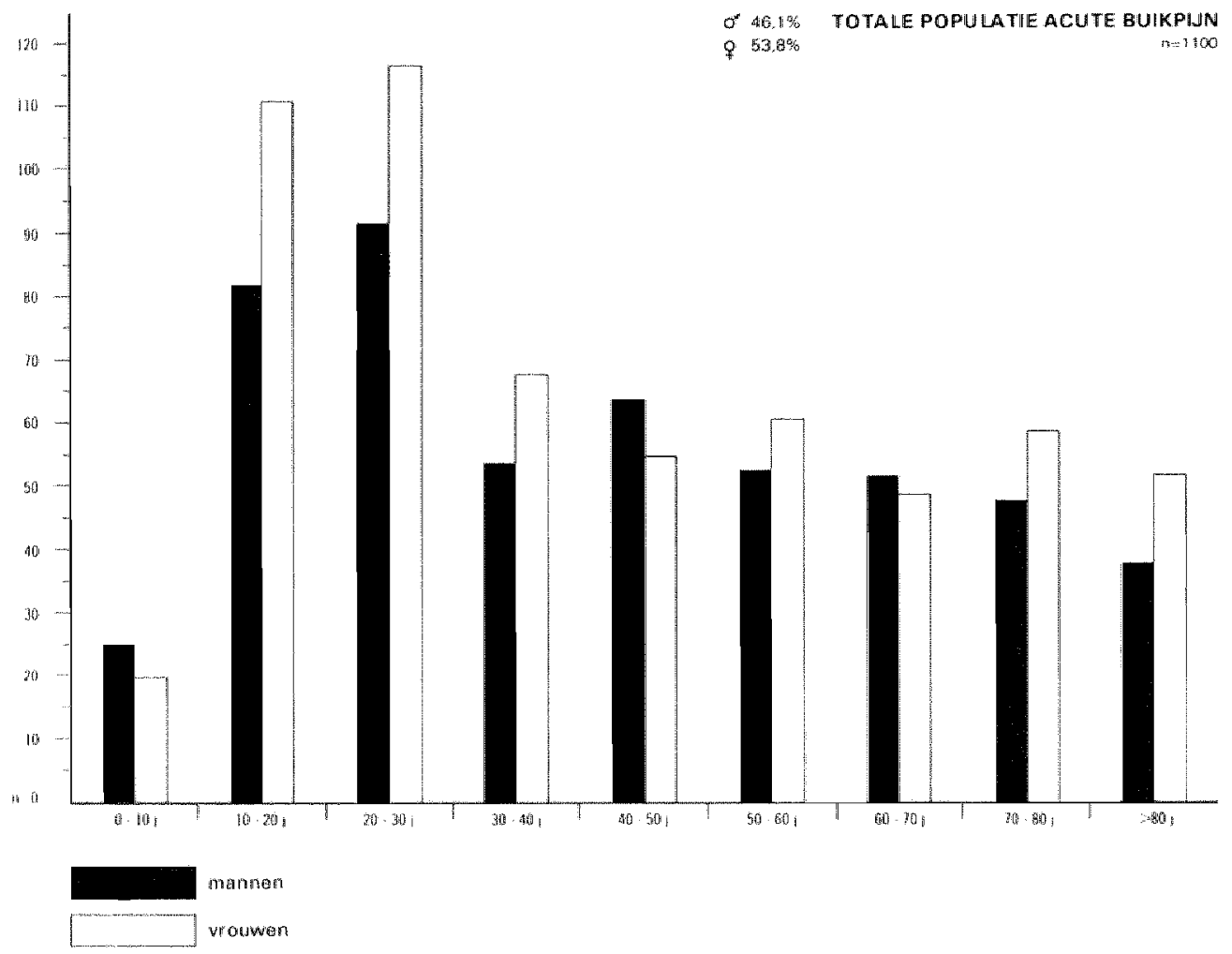

Figutur 8.10

Gestachus-en leefijidsopbouw van de totale populatie.

Opmerkelijk in figuur 8.10 is in de eerste plaats de grootte van de leeftijdsgroep 10-30 jaar. Specificatie hiervan vindt verderop in deze paragraaf plaats.

Volgens telling van de Provincie Limburg was het percentage vrouwen op 31 december 1983 binnen de regio Maastricht 49,6\% en het percentage mannen $50,4 \%$. Deze percentages corresponderen niet geheel met die in figuur 8.10. Nadere precisering van de geslachts- en leefrijdsopbouw per aparte categorie einddiagnose wordt getoond in figuur 8.11 , figuur $8.12 \mathrm{en}$ in bijlage $47 \mathrm{en} 48$. 


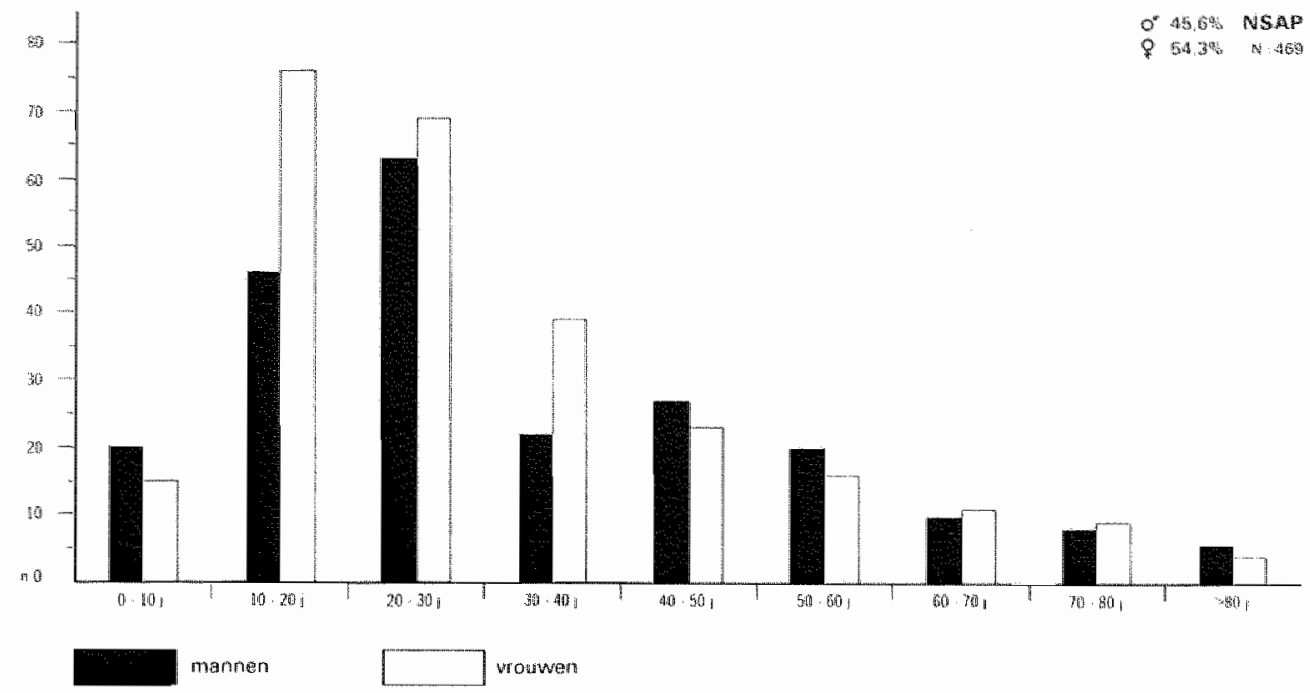

Figuur 8.11

Leeftijds- en geslachtsopbouw van de casus met als einddiagnose Non Specific Abdominal Pain. Totale populatie.
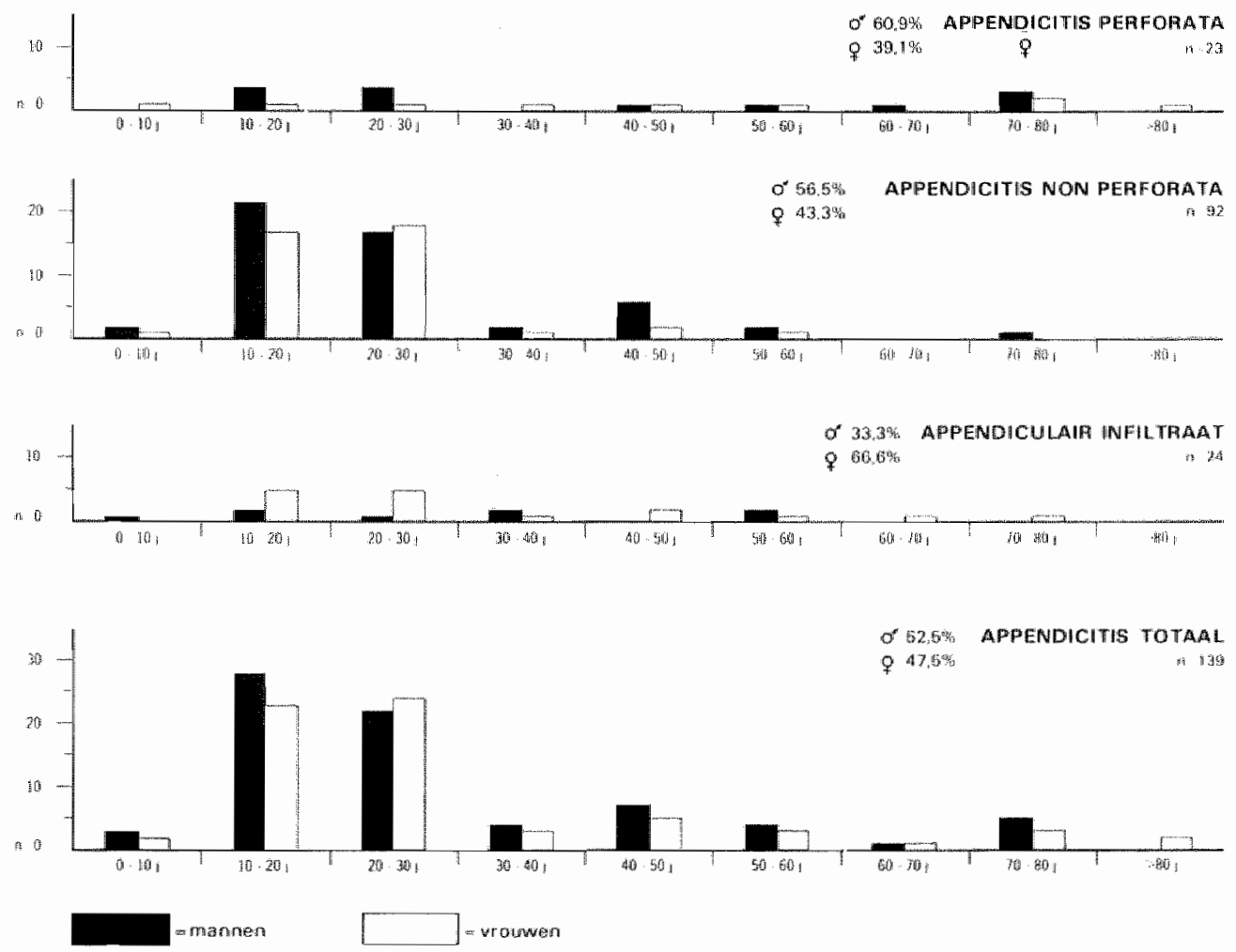

Figuur 8.12

Leeftijds- en geslachtsopbouw van de casus met als einddiagnose appendiciris. "Totale populatie. 
Uit figuur 8.11 blijkt niet alleen dat meer vrouwen dan mannen in de Acute Buik Analyse als einddiagnose Non Specific Abdominal Pain kregen, maar vooral dat deze einddiagnose in hoofdzaak werd gesteld bij de leeftijdscategorie 10-30 jaar.

Uit figuur 8.12 blijkt dat iets meer mannen dan vrouwen als einddiagnose appendicitis kregen en dat, zoals bij de einddiagnose Non Specific Abdominal Pain, de diagnose voornamelijk werd gesteld bij de leeftijdscategorie 10-30 jaar.

Uit figuur $8.11,8.12$ en bijlage 47 blijkt dat in de relatief grote leeftijdsgroep van 10-30 jaar vooral de einddiagnosen Non Specific Abdominal Pain en appendicitis voorkwamen. Op enkele uitzonderingen na werden de overblijwende categorieën einddiagnoses hoofdzakelijk gevonden in de leeftijdsgroep ouder dan 50 jaar. Hoe de procentuele verdeling Non Specific Abdominal Pain, appendicitis acuta en de overblijvende diagnoses was binnen de leeftijdscategorie $10-30$ jaar en ouder dan 50 jaar, is te zien in figuur 8.13:
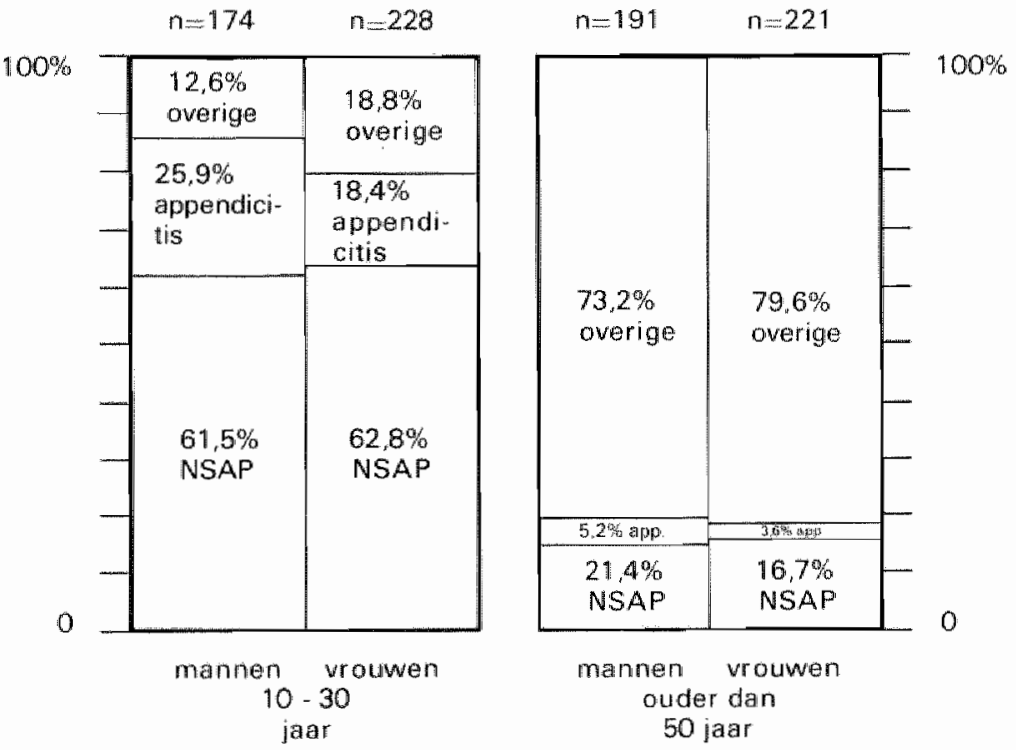

Figuur 8.13

Procentuele verdeling Non Specific Abdominal Pain, appendicitis acuta en de overblijvende diagnoses voor de leefujdscategorieën 10-30 jaar en ouder clan 50 jaar.

Binnen de totale populatie hadden de $10-30$ jarigen voor ongeveer $62 \%$ Non Specific Abdominal Pain en voor ongeveer $21 \%$ appendicitis acuta als einddiagnose. Voor de groep ouder dan 50 jaar waren deze percentages veel lager. Hoe figuur 8.13 tot stand $\mathrm{kwam}$ is te zien in bijlage 48 . 


\subsection{Groep A (zelfverwijzers)}

In deze paragraaf wordt groep A (figuur 8.2) gespecificeerd en vergeleken met de casus welke door een huisarts naar de EHBO werden verwezen (groep C, D en E). Dit werpt licht op de kwestie of zelfverwijzing een wenselijk fenomeen is en gestimuleerd dan wel afgeremd zou moeten worden. Het probleem zelfverwijzing is al aan de orde geweest in paragraaf 8.3. In de Acute Buik Analyse gaat het om total 160 casus, $14,5 \%$ van de totale populatie (figuur 8.2).

Om na te kunnen gaan waarin groep A verschilt van groep C, D en E (door een huisarts verwezen) worden achtereenvolgens de op de EHBO gestelde waarschijnlijkheidsdiagnoses, het op grond hiervan gevoerde beleid en de einddiagnoses voor de beide groepen met elkaar vergeleken.

Tabel 8.14 geeft de op de EHBO gestelde waarschijnlijkheidsdiagnoses weer. Alle andere diagnoses dan Non Specific Abdominal Pain zijn in één categorie "overige diagnoses" samengebracht omdat de aparte categorieën diagnoșes in groep A getalsmatig zo klein waren dat vergelijking met dezelfde categorieën in de groepen $\mathrm{C}, \mathrm{D}$ en $\mathrm{E}$ niet relevant is (bijlage 19).

\section{Tabel 8.14}

Vereenvoudigde weergave van de op de EHBO gestelde waarschijnlijkheidsdiagnoses. Groep A versus groep $C, D$ en $E$.

\begin{tabular}{lll}
\hline $\begin{array}{l}\text { Waarschijnlijkheidsdiagnose } \\
\text { gesteld op de EHBO }\end{array}$ & $\begin{array}{l}\text { Zelfverwijzers } \\
\text { (groep A) }\end{array}$ & $\begin{array}{l}\text { Door huisarts verwezen } \\
\text { (groep C, Den E) }\end{array}$ \\
\hline Aantal $(\%)$ & Aantal $(\%)$ \\
\hline Non Spec. Abd.Pain & $75(47)$ & $200(22)$ \\
Overige & $85(53)$ & $709(78)$ \\
\hline Totaal & $160(100)$ & $909(100)$ \\
\hline
\end{tabular}

Uit tabel 8.14 blijkt dat het percentage Non Specific Abdominal Pain bij groep A meer dan twee maal zo hoog was dan bij de groep die door een huisarts naar de EHBO verwezen werd. Het op grond van deze diagnoses gevoerde beleid is te zien in tabel 8.15:

Tabel 8.15

Beleid EHBO. Groep A versus groep C, D en E.

\begin{tabular}{lll}
\hline Beleid op de EHBO & $\begin{array}{l}\text { Zelfverwijzers } \\
\text { (groep A) } \\
\text { Aantal }(\%)\end{array}$ & $\begin{array}{l}\text { Door huisarts verwezen } \\
\text { (groep C, D en E) } \\
\text { Aantal (\%) }\end{array}$ \\
\hline Opname ziekenhuis & $72(45,0)$ & $659(72,5)$ \\
Controle polikliniek & $61(38,1)$ & $225(24,7)$ \\
Verwijzing huisarts & $27(16,9)$ & $25(2,7)$ \\
\hline Totaal & $160(100)$ & $909(100)$ \\
\hline
\end{tabular}


Uit tabel 8.15 blijkt niet alleen dat er bij groep A procentueel minder casus in het ziekenhuis werden opgenomen en, ipso facto, meer casus op de poliklinieken werden gecontroleerd, maar ook dat het percentage onmiddellijke terugverwijzingen vanuit de $\mathrm{EHBO}$ naar de huisarts of zijn plaatsvervanger ruim zes maal hoger was dan bij groep C, D en E. Her aantal en percentage opnames is in tabel 8.16 gespecificeerd naar de op de EHBO gestelde waarschijnlijkheidsdiagnoses en naar groep.

Tabel 8.16

Opnames per categorie op de EHBO gestelde waarschijnlijkheidsdiagnoses. Groep A versus groep C, D en E. Zie ook bijlage 18.

\begin{tabular}{lcc}
\hline $\begin{array}{l}\text { Waarschijnlijkheidsdiagnose } \\
\text { gesteld op de EHBO }\end{array}$ & Groep A & Groep C, Den E. \\
& Aantal (\%) & Aantal (\%) \\
\hline Non Specific Abdominal Pain & $2(3)$ & $18(9)$ \\
Overige & $70(82)$ & $641(90)$ \\
\hline Totaal & $72(45)$ & $659(72,5)$ \\
\hline
\end{tabular}

Uit tabel 8.16 en bijlage 18 blijkt niet alleen dat er procentueel in totaal minder opnames waren bij groep A, maar dat dit eveneens zo was per afzonderlijke categorie diagnoses.

Het terugverwijzen naar de huisarts gebeurde altijd onder de diagnose Non Specific Abdominal Pain. Hoe vaak de diagnose Non Specific Abdominal Pain werd gesteld bij groep A en groep C, Den E is te zien in tabel 8.17:

Tabel 8.17

Einddiagnoses. Groep A versus groep C, D en E.

\begin{tabular}{lll}
\hline Einddiagnose & $\begin{array}{l}\text { Zelfverwijzers } \\
\text { Groep A }\end{array}$ & $\begin{array}{l}\text { door huisarts verwezen } \\
\text { Groep C, D en E }\end{array}$ \\
\hline Non Specific Abdominal Pain & $103(64,4)$ & Aantal $(\%)$ \\
Overige & $57(35,6)$ & $354(38,9)$ \\
\hline Totaal & $160(100)$ & $555(61,1)$ \\
\hline
\end{tabular}

Uit tabel 8.17 komt naar voren dat het percentage Non Specific Abdominal Pain als einddiagnose bii groep A veel hoger was dan bij de groep die door een huisarts werd 
verwezen. De overige diagnoses zijn gespecificeerd in bijlage 19. Bij de discussie in paragraaf 8.12 .3 wordt aan de problematiek rond het fenomeen zelfverwijzing uitgebreid aandacht geschonker.

Tenslotte zijn nog enkele details de moeite van het vermelden waard.

Bij groep A werden 21 patiënten gedurende de week die vooraf ging aan de zelfverwijzing een of meerdere malen door een of meer huisartsen wegens buikpijn onderzocht. De einddiagnoses waren: $14 \mathrm{x}$ Non Specific Abdominal Pain, $2 \mathrm{x}$ appendicitis non perforata, $2 \mathrm{x}$ coprostasis, $\mathrm{lx}$ torsio testis, $\mathrm{lx}$ ulcus duodeni en tenslotte $\mathrm{lx}$ hernia inguinalis non incarcerata.

Negen patiënten waren meer dan één keer op de EHBO geweest met acute buikpijn terwijl zij zichzelf minstens eenmaal hadden verwezen (bijlage 17). Uit deze bijlage bilikt dat bij slechts één patiënt het interval tussen twee onderzoeken op de EHBO kleiner was dan een week ( $2 \times$ NSAP).

Bii groep A zijn tijdens opname 2 patiènten overleden ( $1,3 \%$, ileum-perforatie, subphrenisch abces). Ter vergelijking: de sterfte in groep $\mathrm{C}, \mathrm{D}$ en $\mathrm{E}$ was $4 \%$ ( 37 casus). Bij de niet opgenomen casus was geen sterfte. Zie verder tabel 8.8 ter vergelijking.

\subsection{Waarneming, spoed, consulten en visites.}

In deze paragraaf worden de begrippen waarneming, spoed en consult/visite binnen het huisartsgeneeskundige handelen nader bestudeerd. In hoofdzaak wordt groep $E$ belicht, omdat die groep de meeste voor deze paragraaf relevante informatie bevat. Waar mogelijk en zinvol zullen deze begrippen worden gerelateerd aan de gestelde diagnoses. Eveneens wordt bekeken hoeveel casus gedurende de week voorafgaande aan de verwijzing voor dezelfde klachten al eerder door een of meer huisartsen werden onderzocht.

Allereerst wordt het begrip waarneming behandeld. Een waarneemsituatie is in de Acute Buik Analyse gedefiniëerd als die situatie, waarin een patiënt wordt onderzocht door een huisarts die hij of zij niet als de eigen huisarts beschouwt. Indien een groepspraktijk of een associatie als "huisarts" zou worden opgegeven door de patiënt, kan er natuurliik geen sprake zijn van waarneming volgens bovenstaande definitie bij behandeling door een of meer in deze praktijk werkzaam zijnde artsen. In de Acute Buik Analyse is zo'n situatie echter niet woorgekomen. De verdeling "verwezen tijdens waarneming" en "verwezen door de eigen huisarts" is als volgt (tabel 8.18):

Tabel 8.18

Tijdens waarneming en door eigen huisarts verwezen.

Groep C, D en E. (door een huisarts verwezen)

\begin{tabular}{ll}
\hline Verwijzer & Aantal $(\%)$ \\
\hline Waarneming & $238(26,2)$ \\
Eigen huisarts & $671(73,8)$ \\
\hline Totaal & $909(100)$ \\
\hline
\end{tabular}


Uit tabel 8.18 blijkt dat iets meer dan een vierde van alle verwijzingen door huisartsen van patiënten met acute buikpijn naar de EHBO is gebeurd tijdens waarneming. Deze verdeling geldt grosso modo eveneens voor de groepen apart (bijlage 22). Ter oriëntatie: in de regio Maastricht zijn de huisartsen woor hun eigen praktijken op jaarbasis gemiddeld 3394 uur of $38,7 \%$ (een kalenderjaar telt 8760 uur) van alle tijd beschikbaar.

Terugkijkend naar tabel 8.18 valt dus op dat in $38,7 \%$ van alle tijd $73,8 \%$ van alle casus van groep $C, D$ en $E$ naar de $E H B O$ verwezen werd! Tijdens de discussie wordt op deze bevinding teruggekomen( paragraaf 8.12 .4 ).

De verdeling van de huisarts-patiënt contacten in visites/consulten al dan niet met spoedeisend karakter kan uitsluitend bestudeerd worden bij groep E. In deze groep zijn immers de benodigde gegevens beschikbaar. Wat onder consult en visite verstaan moet worden ligt voor de hand: bij een visite gaat de dokter naar de patiënt toe om hem aan het ziekbed te onderzoeken, bij een consult is de patiënt naar de dokter toe gekomen op zijn praktijkadres. Bij een visite is de patiënt in de regel niet of niet goed in staat om naar de dokter toe te gaan. Niet alleen medische redenen, maar ook ontbreken van vervoer, druk door de patiënt op de huisarts uitgeoefend enzovoort kunnen leiden tot een visite.

Het aantal visites en consulten is weergegeven in tabel 8.19:

Tabel 8.19

Consulten/visites. Groep E.

\begin{tabular}{ll}
\hline & Aantal $(\%)$ \\
\hline Consulten & $243(43,0)$ \\
Visites & $321(56,9)$ \\
\hline Totaal & $564(100)$ \\
\hline
\end{tabular}

In tabel 8.19 is te zien dat het percentage visites iets groter was dan het percentage consulten. Specificatie van deze aantallen en percentages naar einddiagnose is te zien in bijlage 24 . Opvallend is dat het percentage consulten voor de einddiagnose Non Specific Abdominal Pain veel hoger was dan het gemiddelde. In mindere mate ging dit ook op voor de einddiagnose appendicitis. Hierop wordt teruggekomen in paragraaf 8.12.4..

Het aantal door de huisartsen als spoed gekarakteriseerde casus is tegen de consulten en visites uitgezet in tabel 8.20 . De werkdefinitie luidde dat bij spoed het werk (of de vrije tijdsbesteding) onderbroken moet worden om op korte termijn de verlangde hulp te verlenen (Smit 1974) of anders gezegd: de patiënt en/of dokter vinden dat medische onderzoek geen uitstel kan lijden.

Tabel 8.20

(Spoed) consulten en (spoed) visites. Groep E.

\begin{tabular}{llll}
\hline & Aantal consulten $(\%)$ & Aantal visites $(\%)$ & Totaal $(\%)$ \\
\hline Spoed & $107(44,0)$ & $131(40,8)$ & $238(42,2)$ \\
Geen spoed & $136(56,0)$ & $190(59,2)$ & $326(57,8)$ \\
\hline Totaal & $243(100)$ & $321(100)$ & $564(100)$ \\
\hline
\end{tabular}


De kwalificatie "spoed" werd door de huisartsen in bijna gelijke percentages aan zowel consulten als visites gegeven. Het gemiddelde is $42,2 \%$. Specificatie van de aantallen en percentages (spoed)consulten en (spoed)visites naar einddiagnose is te zien in bijlage 23 . Opvallend in deze bijlage zijn de bijna gelijke percentages spoed bij de einddiagnoses Non Specific Abdominal Pain en appendicitis acuta.

Tenslotte nog enkele vermeldenswaardige details. Bij de 564 casus in groep $\mathrm{E}$ werd er op de huisartsen- en specialistenformulieren 181 maal $(32,1 \%$ of bijna een derde wan de gevallen) vermeld, dat de patiënt in de week voorafgaande aan de verwijzing naar de EHBO een of meer keer door een of meer huisartsen in successie voor dezelfde klacht werd onderzocht (bijlage 25 en 26). Hoe vaak er telefonisch contact was tussen arts en patiënt, dat niet resulteerde in onderzoek is niet bekend. Van deze patiënten overleden er 2 gedurende opname. De een ten gevolge van circulatie-stoornissen na een operatie wegens geperforeerd ulcus pepticum, en de ander door cachexie ten gevolge van een maligne aandoening van het colon.

\subsection{Discussie}

Omdat de discussie over een grote hoeveelheid informatie gaat, is deze paragraaf omwille van de duidelijkheid en het overzicht, in vieren gedeeld:

1. algemeen;

2. categorieën einddiagnoses;

3. groep A (zelfverwiizers);

4. waarneming, spoed, consulten en visites.

\subsubsection{Algemeen}

Uit figuur 8.2 blijkt dat het overgrote deel $(71,9 \%)$ van de totale onderzoekspopulatie door een huisarts werd verwezen die deelnam aan de Acute Buik Analyse. Deze casus werden voor $65,8 \%$ vergezeld van een correct ingevuld huisartsenformulier. Deze mate van coöperatie aan de Acute Buik Analyse mag zeer bevredigend genoemd worden. Door de toch lange looptijd (19 maanden) van het onderzoek, de tijd en inspanning vergende invulling van de formulieren, de gevraagde kwetsbare opstelling van de huisartsen door zich te laten beoordelen en, last but not least, de vrijwilligheid en vrijblijvendheid van de eventuele deelname, was het bij aanvang van de Acute Buik Analyse nog maar de vraag of het onderzoek wel tot een goed einde zou komen! Er bestond tenslotte geen enkele mogelijkheid tot contra-prestatie of sanctionering bij in gebrekte blijven. De getoonde bereidheid tot medewerking is hoogstwaarschijnliik bepaald door interesse in het onderwerp en goodwill ten opzichte van een collega-huisarts-onderzoeker.

Dat de meeste casus bij de chirurg terechtkwamen (tabel 8.3) is natuurlijk niet verrassend als de verwijsdiagnoses (tabel 8.4) in aanmerking worden genomen. Achter een aantal van deze verwijsdiagnoses zou ten opzichte van het specialisme waarnaar verwezen werd een vraagteken kunnen worden gezet (appendicitis, pancreatitis, gynaecologische afwijkingen). Naar welk specialisme verwezen zou moeten worden is overigens vaak arbitrair. Meestal is het een kwestie van gewoonte. Dat een duidelijke appendicitis bij de chirurg 
thuishoort, daarover is weinig discussie. Maar wat te doen met onduidelijke buikklachten of met een verdenking op pancreatitis? Uit de vele telefoongesprekken die met bijna alle meewerkende huisartsen zijn gevoerd bleek dat de ene huisarts bij zulke gevallen liever eerst naar de chirurg en de ander maar liever eerst naar gynaecoloog of internist verwijst. Ook onder de specialisten bestaat geen communis opinio over dit probleem. Bijna iedere arts kent de discussie die hicrover regelmatig in de kliniek wordt gevoerd.

Tenslotte kan het, zelfs na het meest zorgvuldig afgewogen verwijsbeleid, blijken dat de patiênt toch bij een ander specialisme thuishoort: een ziektebeeld kan immers snel in de tijd veranderen (Cope 1979).

Relevante literatuur over het verwijsgedrag van de huisarts is schaars. Blacklack (1976) meldt dat in een serie van 407 casus met acute buikklachten, $81,2 \%$ door een huisarts was verwezen. De rest was hoofdzakelijk zelfverwijzer.

Op de vraag hoeveel casus eigenlijk niet opgenomen hadden moeten worden is natuurlijk geen antwoord te geven. Een ziektebeeld kan op zeer verdedigbare gronden aanleiding geven tot opname terwijl achteraf geen aannemelijke objectieve oorzaak voor de klacht wordt gevonden. Daarnaast bestaat er geen consensus over opname-indicaties. De ene arts zal sneller om hem moverende redenen tot opname overgaan dan de andere.

Ook kan (mede) tot opname worden besloten om (psycho)sociale redenen.

Onmiddellijke terugverwijzing naar de huisarts vanuit de $\mathrm{EHBO}$ gebeurde in 56 gevallen (tabel 8.6 ), slechts $5,1 \%$ van de totale populatie en $15,3 \%$ van de niet onmiddellijk op de EHBO opgenomen casus. Hadden er niet meer casus op een verantwoorde wijze na eenmalig onderzoek op de EHBO direct terugverwezen kunnen worden?

Uit bijlage 6 blijkt dat bij slechts 51 of $16,4 \%$ van de 311 op de polikliniek terugbestelde casus uiteindelijk objectieve afwijkingen konden worden vastgesteld. Van de op de EHBO gestelde waarschijnlijkheidsdiagnoses Non Specific Abdominal Pain welke poliklinisch werden gecontroleerd ( 218 casus), bleef $95,4 \%$ onveranderd a-specifiek (paragraaf 8.5). Hieruit mag geconcludeerd worden dat het verantwoord en wenselijk is om bij een gelijkblijvend opnamebeleid meer casus, waarbij in eerste instantie op de EHBO de klachtendiagnose Non Specific Abdominal Pain werd gestelld eerder onder controle van de huisarts of diens plaatsvervanger te stellen.

$\mathrm{Bij} 29(7,3 \%)$ van de in totaal 396 verrichte buikoperaties (paragraaf 8.6 en bijlage 7 ) bleek achteraf géén objectieve verklaring voor de klachten mogelijk. Dit getal "negatieve laparotomieën" is laag te noemen in vergelijking tot de cijfers uit de internationale literatuur, variërend van 20\% tot, in sommige centra in West-Duitsland, $80 \%$ (De Dombal 1980).

Van de 138 wegens vermoedeliike appendicitis geopereerde patiënten bleken er 20 $(14,5 \%)$ een appendix sana te hebben. Internationaal lag dit percentage gemiddeld op $25 \%$ (De Dombal 1979;1). Het in de Acute Buik Analyse gevonden percentage is dus erg laag. Dit lage percentage pleit voor de kwaliteit van het klinische beslissingsproces op de EHBO en de chirurgische afdelingen. Achtereenvolgens worden nu de afzonderlijke diagnoses besproken zoals ze naar indeling en aantal te zien ziin in paragraaf $8.7 \mathrm{en} 8.9$. Met name vóórkomen, mortaliteit en geslacht/leeftijd komen aan de orde. 


\subsubsection{Categorieën einddiagnoses}

\section{Non Specific Abdominal Pain ( 469 casus)}

De term is in de 70-er jaren geïntroduceerd. Eigenlijk mag hier niet over een diagnose gesproken worden: het is meer een verzamelbegrip, de uitdrukking van het onvermogen om een diagnose te stellen.

De kenmerken ervan zijn:

1. het niet aanwezig zijn van objectieve afwijkingen waarvan met grote waarschijnlijkheid mag worden gezegd dat de buikklachten hiermee verklaard zijn;

2. de klachten waren "self-limitung".

Welke einddiagnoses onder de noemer Non Specific Abdominal Pain werden gerangschikt is te zien in bijlage 45 . Opvallend is dat in 437 gevallen geen enkele diagnose is gesteld: men had eenvoudigweg geen verklaring voor de buikklachten. Bij follow-up van de patiënten die onder de diagnose Non Specific Abdominal Pain uit het ziekenhuis of uit poliklinische controle werden ontslagen bleek dat gedurende de onderzoeksperiode bij slechts 5 van deze patiënten heronderzoek plaatsvond waarbij een andere diagnose werd gesteld (bijlage 8 ).

Jess (1982) vond bij een follow-up van 230 gevallen met de einddiagnose Non Specific Abdominal Pain gedurende vijf jaar 1 geval van overlijden gerelateerd aan de symptomen van het begin en 10 heropnames wegens appendicitis. Zoals de bevindingen bij de Acute Buik Analyse al suggereerden liikt verandering van einddiagnose Non Specific Abdominal Pain in het algemeen zelden voor te komen.

Uit de leeftijds- en geslachtsopbouw (figuur 8.11) blijkt dat er een leeftijdspiek bestaat voor de categorie 10-30 jaar en een voorkeur voor het vrouwelijke geslacht. Staniland (1972) en Petit (1984) kwamen tot dezelfde bevindingen.

\section{Appendicitis (139 casus)}

De einddiagnose appendicitis (ontsteking van de appendix vermiformis) is een verzamelbegrip (bijlage 9). Het omvat appendicitis perforata $(\mathrm{n}=23)$, appendicitis non perforata $(n=92)$ en appendiculair infiltraat $(n=24)$. Alle einddiagnoses appendicitis werden pathologisch-anatomisch bevestigd. Volgens opgave van het SIG/Informatiecentrum voor de gezondheidszorg (een groot deel van alle Nederlandse Ziekenhuizen geven hieraan jaarlijks hun statistische gegevens door) blijkt dat het percentage perforaties gedurende de onderzoeksperiode in de provincie Limburg 16,6\%, en voor heel Nederland $17,6 \%$ ten opzichte van alle appendicitiden was. Het percentage kon hoog oplopen (30\%, Jordan 1980). Internationaal lag het gemiddelde rond de 25\% (De Dombal 1979;1). Het in de Acute Buik Analyse gevonden percentage perforaties van $16,5 \%$ is niet afwijkend te noemen in vergelijking tot de hier genoemde nationale en internationale percentages. Zowel in de provincie Limburg als in de rest van Nederland bleek de mortaliteit $0,2 \%$ te zijn. In de Maastrichtse studie was geen sterfte tijdens opname (tabel 8.8).

Staniland (1972) en Petit (1984) vonden bii de appendicitiden meer mannen en een voorkeur ten aanzien van de leeftijdsgroep 10-30 jaar.

Gillmore (1978) en Dubecz (1976) vonden bij perforaties twee maal zoveel mannen als vrouwen. Uit figuur 8.12 blijkt dat de Acute Buik Analyse tot dezelfde bevindingen $\mathrm{kwam}$. Een plausibele verklaring voor dit fenomeen is in de literatuur niet aangetroffen. 
In een retrospectieve analyse zag van Meeteren (1985) bij perforaties leefrijdspieken beneden de 10 en boven de 50 jaar. Voor zo'n laatste leeftijdspiek zijn in de Maastrichtse studie geen duidelijke aanwijzingen gevonden (figuur 8.12).

\section{Cholecystitis ( 65 casus)}

Onder her begrip cholecystitis wordt hier verstaan een pathologisch anatomisch bevestigde ontsteking van de galblaas. Bijlage 9 laat de verdeling in acute $(n=29)$ en chronische $(\mathrm{n}=36)$ casus zien.

De mortaliteit bij cholecystitis was in de provincie Limburg 3,4\% en in heel Nederland 3,1\% (gegevens: SIG). Bij de Acute Buik Analyse was geen sterfte (tabel 8.8). Staniland (1972) en Petit (1984) vonden leeftijdspieken in de categorie 60-80 jaar en een voorkeur voor het vrouwelijk geslacht, die zich echter pas manifesteerde boven het vijftigste jaar. In de Acute Buik Analyse werden analoge bevindingen gedaan (bijlage 47).

\section{Obstructie dunne darm ( 35 casus)}

Het merendeel wan de obstructies van de dunne darm werd veroorzaakt door een streng(bijlage 14).

Staniland (1972) en Petit (1984) vonden een voorkeur voor mannen en een in hoofdzaak voorkomen van de aandoening boven het vijftigste levensjaar. In de Maastrichtse studie werd eenzelfde leeftijdspatroon, maar daarentegen een grote voorkeur voor het vrouwelijk geslacht gevonden $(80 \%$, bijlage 47$)$.

De mortaliteit was vrij hoog: $14,2 \%$ (tabel 8.8 ).

\section{Geperforeerd ulcus pepticum (20 casus)}

De mortaliteit van deze aandoening was in de Acute Buik Analyse 15\%. Voor de provincie Limburg was de mortaliteit $16 \%$, voor heel Nederland 16,7\% (gegevens: SIG). Staniland (1972) en McKay (1976) vonden een voorkeur van mannen van $85 \%$, Petit (1984) vond 50\% mannen. Beneden de 40 jaar kwam de aandoening bij alle onderzochte populaties slechts sporadisch voor. De Maastrichtse bevindingen komen overeen met die van Petit (bijlage 47).

\section{Pancreatitis ( 50 casus)}

Als pancreatitis wordt in de Acute Buik Analyse beschouwd een geval van acute bovenbuikspijn met een serum-amylase van meer dan $1000 \mathrm{U} / 1$ en de afwezigheid van andere aandoeningen die de stijging van het serum-amylase zouden kunnen verklaren, zoals een geperforeerd ulcus pepticum, een strangulatie-ileus of acute cholecystitis (Roesch 1975, Saegesser 1981, Haffter 1983).

Bijlage 15 geeft het aantal oorzaken van de pancreatitiden weer.

De mortaliteit voor de provincie Limburg was gedurende de onderzoeksperiode $6,1 \%$, voor heel Nederland was dit percentage $8,2 \%$. De mortaliteit in de Acute Buik Analyse was $8 \%$. Dit is niet afwijkend van het nationale gemiddelde. Gail (1975), Battersby (1977) en Petit (1984) vonden een leeftijdspiek op jongere en een kleinere leeftijdspiek op oudere leeftijd. Eveneens vonden zij een lichte voorkeur voor mannen. In de Acute Buik Analyse zijn dezelfde leeftijdspieken gevonden maar daarentegen een lichte voorkeur voor vrouwen (bijlage 47). 


\section{Overige diagnoses ( 322 casus)}

Wegens de overwegend kleine aantallen casus per aparte categorie einddiagnose (bijlage 9,12 en 13) wordt op de "overige diagnoses" verder geen commentaar gegeven.

Uit de veelheid van aantallen en percentages bij de hiervoor genoemde categorieën einddiagnoses valt op dat de fractie Non Specific Abdominal Pain numeriek de grootste plaats inneemt. Internationaal ligt dit niet anders (tabel 8.9). In aanmerking nemende dat ruim eenderde van alle casus Non Specific Abdominal Pain in het ziekenhuis werd opgenomen (bijlage 6), zou het te wensen zijn dat deze diagnose a priori met een grotere graad van nauwkeurigheid zou kunnen worden gesteld. Onderzoek naar causa en symptomatologie van a-specifieke acute buikklachten dient dan ook bevorderd te worden.

Speciale aandacht verdient de bevinding zoals aangegeven in figuur 8.13 ; op grond van leeftijd alleen moet dan ook het volgende overwogen worden met betrekking tot de klinische beslissingsprocedure:

1. bij patiënten ouder dan 50 jaar was de kans op een ernstige oorzaak van acute buikpijn $81,6 \%$, ruim twee maal zo groot als bij de $10-30$ jarigen. Er bestond een voorkeur voor cholecystitis, vasculaire aandoeningen en maligniteit;

2. bij de leeftijdsgroep 10-30 jaar was diezelfde kans ipso facto niet alleen twee maal zo klein, maar bestond er bovendien bij ernstige acute buikaandoeningen nog een duidelijke voorkeur voor appendicitis.

Gesteld mag worden dat in geval van acute buikpijn de kans op ernstige buikpathologie toeneemt met de leeftijd: de kans op appendicitis neemt met het vorderen van de leeftijd af, de kans op met name cholecystitis, vasculaire aandoeningen en maligniteit neemt daarentegen toe.

Met de toenemende vergrijzing van de bevolking zal het aanbod van patiënten met acute buikpijn in Nederland van samenstelling veranderen. Het aandeel Non Specific Abdominal pain en appendicitis zal kleiner worden. Het aandeel ernstige acute buikaandoeningen zal toenemen.

\subsubsection{Groep A (zelfverwijzers)}

Groep A lijkt een niet onaanzienlijke groep: $14,5 \%$ of eenzewende van de totale onderzoekspopulatie van 1100 casus. Het traditionele systeem, dat een patiënt in principe door een huisarts naar de specialist wordt verwezen, is blijkbaar niet sluitend.

Over wat de patiënt bewogen heeft om de huisarts te passeren valt slechts te filosoferen. Het lijken veelal factoren van emotionele en/of praktische aard, zoals:

1. verstoorde huisarts-patiënt relatie van recente oorsprong of van langere duur;

2. het gemakkelijker bereiken van de vaste locatie van de EHBO dan de steeds wisselende adressen van de waarnemende huisartsen;

3. het niet willen, kunnen of durven storen van de huisarts of zijn waarnemer op nachtelijke uren of zelfs overdag.

Uit bijlage 26 a blijkt dat $13,1 \%$ van de zelfverwijzers gedurende de week voorafgaande aan het onderzoek op de EHBO voor dezelfde klachten al eerder door een huisarts gezien was. In deze gevallen zou van een verstoorde huisarts-patiënt relatie kunnen worden gesproken. Voor zover te beoordelen is er slechts in één geval sprake van laakbaar medisch handelen: een patiënt met een torsio testis is na diverse onderzoeken door de huisarts 
enkele weken na het ontstaan van zijn klachten uit eigen initiatief naar de EHBO gegaan. Natuurlijk kunnen ook andere factoren bij het besluit om uit eigen beweging naar de EHBO te gaan een rol hebben gespeeld. Over het aantal onbevredigend verlopen telefoongesprekken tussen patiént en huisarts dat tot zelfverwijzing heeft geleid is geen informatie. Een onbekende hoeveelheid conflictueuze situaties is waarschijnlijk via de EHBO gekanaliseerd.

Bij vergelijking van groep $\mathrm{A}$ (zelfverwijzers) met groep $\mathrm{C}, \mathrm{D}$ en $\mathrm{E}$ (door huisarts verwezen) valt het volgende op:

1. het percentage "Non Specific Abdominal Pain" was bij groep A bijna twee maal zo hoog als bij groep $C_{3} \mathrm{D}$ en $\mathrm{E}$ (tabel 8.17);

2. bij groep $A$ was het percentage opnames in het ziekenhuis veel lager dan bij groep $C, D$ en $E$ (tabel 8.16);

3. per categorie op de EHBO gestelde waarschijnlijkheidsdiagnoses werden in groep A procentueel veel minder casus opgenomen in het ziekenhuis dan bij groep $\mathrm{C}, \mathrm{D}$ en $\mathrm{E}$ (tabel 8.16, bijlage 18);

4. bij de niet opgenomen casus was het percentage terugverwijzingen naar de huisarts bij groep A ruim zes maal zo hoog als bii groep C, D en E (tabel 8.15).

De voornaamste conclusie die uit deze verschillen getrokken kan worden is dat het aantal casus dat niet als ernstig genoeg imponeerde om voor opname in aanmerking te komen in groep A (zelfverwijzers) veel groter was dan in groep C, D en $\mathrm{E}$ (door huisarts verwezen). Kortom: het aantal "niet zieken" (Knottnerus 1985) was in groep A veel groter. Dit is natuurljk geen echt verrassende conclusie. Hoewel het aantal zelfverwijzers in absolute en relatieve zin erg meeviel moet echter wel gerealiseerd worden dat als het uit eigen initiatief naar de EHBO gaan bij acute buikpijn toe zou gaan nemen, het ziekenhuis zich organisatorisch en qua deskundigheid aan de veranderde samenstelling van de patiëntenstroom moet conformeren. Dit brengt niet alleen een kostenstijging met zich mee, maar eveneens wordt in dat geval aan de huisartsen, bij gelijkblijvend medisch systeem, dan steeds meer leerzame casuïstiek onttrokken waardoor hun vaardigheid vermindert. Het zou van wijs beleid getuigen het fenomeen zelfverwijzing te ontmoedigen, de huisarts selecteert immers scherper dan de patiênt zelf; het is in het kader van dit ontmoedigingsbeleid gewenst om vanuit de $\mathrm{EHBO}$ met de betrokken patiënt en de gepasseerde huisarts over de oorzaken van de zelfverwijzing te praten. Een "education permanente" voor beide partijen!

\subsubsection{Waarneming, spoed, consulten en visites.}

Uit paragraaf 8.11 bleek dat door de aan de Acute Buik Analyse deelnemende huisartsen die maar ruim eenderde van alle tijd voor zijn patiënten beschikbaar waren, bijna drievierde van alle casus naar de EHBO werden verwezen. Dit is vreemd als er van uitgegaan wordt dat:

1. acute buikpijn op elk willekeurig moment kan ontstaan;

2. patiënten met flinke, in hevigheid toenemende buikpijn liever niet te lang wachten met het inroepen van medische hulp.

Deze bevinding kon een aantal oorzaken hebben:

1. de patiënt vond zijn klacht van dien aard dat hij op zijn eigen huisarts wachtte; 
2. de patiënt vond zijn klacht zodanig dat hij tot "kantooruren" wachtte;

3. een waarnemer schoof de problematiek vaker door naar de eigen huisarts;

4. de patiënt ging bij afwezigheid van de eigen huisarts, op incourante uren of na een conflict liever als zelfverwijzer naar de EHBO.

Over punt 1,2 en 3 is in de Acute Buik Analyse geen informatie. Wat betreft punt 4 zal het zeker zijn voorgekomen dat een aantal patiënten om die reden uit eigen beweging naar de EHBO is gegaan. Dit kan echter nooit het gehele probleem verklaren, want zelfs als groep A in zijn totaliteit opgeteld zou worden (wat niet reëel is) bij de casus welke tijdens waarneming werden verwezen $(160+238=398$, tabel 8.18$)$ dan nog zou het percentage casus dat verwezen werd tijdens waarneming maar stijgen van $26,2 \%$ naar $37,2 \%$.

Deze bevindingen en overwegingen maken duidelijk dat er uitgesteld is. Zelfs over het algemeen als extreem pijnlijk omschreven ziektebeelden als geperforeerd ulcus pepticum en obstructie van de dunne darm werden maar liefst voor respectievelijk $55 \%$ en $87,5 \%$ door de eigen huisarts verwezen (bijlage 22). Reden van uitstel is waarschijnlijk multifactorieël. Het zou aanbeveling verdienen dit in een vervolgstudie nog eens preciezer na te gaan. Tijd is immers medebepalend voor de prognose (Cope 1979).

Een ander opvallend punt was dat het percentage consulten op het totale aantal consulten bij de einddiagnose Non Specific Abdominal Pain en appendicitis (respectievelijk 62,8\% en $47,8 \%$, bijlage 24 ) boven het gemiddelde van $43 \%$ lag. Het grote aantal jongeren kan hier mogelijk van betekenis zijn geweest (figuur 8.11). Misschien werd hen door hun jonge leeftijd sneller verzocht, en waren zij ook eerder bereid, om nalar de dokter toe te gaan.

De kwalificatie "spoed" werd door de huisartsen in groep $E$ in bijna gelijke percentages aan zowel consulten als visites toegekend (gemiddeld $42,2 \%$, tabel 8.20 ). Opvallend in bijlage 23 zijn de bijna gelijke percentages spoed bij de einddiagnoses Non Specific Abdominal Pain en appendicitis (respectievelijk 43,7\% en 43,4\%). Omdat acute buikklachten over het algemeen geassocieerd worden met ernst en spoed (hoofdstuk 2 ) is een percentage spoedgevallen van $42,2 \%$ beslist niet hoog te noemen.

\subsection{Conclusies en aanbevelingen betreffende doelstelling 1 .}

\section{Conclusies.}

- Tijdens waarneming werd inroepen van huisartsgeneeskundige hulp bij acute buikklachten uitgesteld.

- Het percentage "spoedgevallen" was lager dan mocht worden verondersteld.

- Er zijn op de EHBO te weinig patiënten onmiddellijk na eerste onderzoek terugverwezen naar de huisarts.

- Bij opname in het ziekenhuis werden vooraf op de EHBO meestal (98\%) anatomisch of causaal gedefinieerde waarschijnlijkheidsdiagnoses gesteld. Bij de niet-opnames was dit percentage slechts $27,5 \%$. Het aantal opnames besloeg tweederde van de totale onderzoekspopulatie. Van deze opnames bleek uiteindelijk $21,8 \%$ Non Specific Abdominal Pain te hebben.

- De percentages "negatieve laparotomieën" en "appendix sana", gevonden in de Acute Buik Analyse zijn laag in vergelijking tot internationale cijfers.

- De kans op ernstige buikpathologie bij acute buikpijn nam toe met de leeftijd; de kans 
op appendicitis daalde.

- Zowel in de Acute Buik Analyse als in andere series nam de categorie einddiagnose Non Specific Abdominal Pain qua aantal de eerste plaats in.

- Bij die casus, welke zich op eigen initiatief meldden op de EHBO met acute buikklachten bleek procentueel bijna twee maal zoveel Non Specific Abdominal Pain voor te komen als bij de casus die door een huisarts naar het ziekenhuis waren verwezen.

\section{Aanbevelingen.}

- In verband met het belang van de factor tijd bij de prognose van acute buikaandoeningen dient onderzocht te worden welke factoren in welke mate bepalend zijn voor uitstel bij het inroepen van huisartsgeneeskundige hullp.

- Het getuigt van wijs beleid het fenomeen "zelfverwijzing" te ontmoedigen.

- Naar aanleiding van de percentages opnames dient onderzoek naar het klinische beeld van Non Specific Abdominal Pain, ten behoeve van vroege herkenning van deze "aandoening", bevorderd te worden. 


\section{Hoofdstuk 9}

\section{TIJDSVERLOOP}

..."That time is money all must realize
But ar this point I wish ro emplasize
That in acute abdominal disease
Time is oft life-remember that first,
please."...
Zeta, 1955

\subsection{Inleiding}

In dit hoofdstuk wordt aandacht besteed aan de tweede doelstelling van de Acute Buik Analyse: tijdsanalyse van de verschillende fasen in het ziekteverloop tot aan ontslag/overlijden. Om deze doelstelling te kunnen realiseren werd de patiënt op de voet gevolgd met, bij wijze van spreken, de stopwatch ernaast. Op de minuut zijn in de Acute Buik Analyse de tijdsverlopen gemeten van de hieronder beschreven fasen in de verschillende ziektegeschiedenissen. Deze tijdsmeting staat natuurlijk volkomen in het teken van vroege diagnostiek en snel therapeutisch handelen. Over het belang van vroege diagnostiek en snel therapeutisch handelen is geen discussie. In vrijwel alle leerboeken en artilkelen komt het naar voren. Enkele voorbeelden:

1. in het algemeen kan gesteld worden dat in de meeste gevallen de heftige buikpiin, die optreedt bij patiënten die voordien redelijk gezond waren en die langer dan 6 uur aanhoudt, veroorzaakt wordt door aandoeningen waarvoor operatieve behandeling noodzakelijk is (Cope 1979);

2. de prognose van acute buikaandoeningen is een functie van de tijd die verloopt tussen het optreden van de eerste symptomen en het moment van handelen, chirurgisch of niet (Siaegesser 1981);

3. de prognose van ischaemische intestinale syndromen is direct afhankelijk van het tijdsverloop vớr behandeling (Honoré 1982).

Om zinvol te kunnen meten is een casus verdeeld in 6 fasen, gemarkeerd door cruciale momenten zoals: het tijdstip waarop de buikpijn begon, het moment waarop medisch onderzoek werd gedaan, enzovoort. Figuur 9.1 geeft een en ander schematisch weer:

\begin{tabular}{ll|l|l|l|l|ll|}
\hline & Fase 1 & Fase 2 & Fase 3 & Fase 4 & Fase 5 & Fanse 6 \\
\hline $\begin{array}{lllll}\text { Begin } \\
\text { buik } \\
\text { piin }\end{array}$ & $\begin{array}{l}\text { Hulpvraag } \\
\text { huisarts }\end{array}$ & $\begin{array}{l}\text { Onderzoek } \\
\text { huisarts }\end{array}$ & $\begin{array}{l}\text { Binnenkomst } \\
\text { EHBO }\end{array}$ & $\begin{array}{l}\text { Onderzoek } \\
\text { EHBO }\end{array}$ & $\begin{array}{l}\text { Aanvang } \\
\text { operatie }\end{array}$ & $\begin{array}{l}\text { Ontsiag/ } \\
\text { overlijden } \\
\text { in } \\
\text { zickenhuis }\end{array}$ \\
\hline
\end{tabular}

Figuur 9.1

Indeling van een ziekteverloop in fasen. 
In het kort worden deze fasen achtereenvolgens gepreciseerd:

\section{Fase 1}

Fase 1 geeft de duur weer vanaf het moment waarop de actuele buikpijn begon tot aan het tijdstip waarop de laatste hulpwraag voor verwijzing werd gesteld. Met nadruk wordt hier gesproken over de laatste hulpvraag voór verwijzing omdat de tijdstippen van eventuele eerdere, al dan niet gehonoreerde, hulpvragen in de Acute Buik Analyse niet nauwkeurig genoeg of onvolledig zijn vastgelegd (bijlage 2 en 3 ). Het moment waarop de buikpijn begon is het enige dat door de patient zelf is vastgesteld.

Onder "hulpuraag huisarts" moet verstaan worden het laatst gelanceerde effectieve verzoek om een consult of een visite aan huisarts en/of assistentie in verband met acute buikpiin vóór verwijzing naar de EHBO.

\section{Fase 2}

Fase 2 geeft de duur weer vanaf het moment dat de hulpvraag aan de huisarts werd gesteld tot aan het ogenblik waarop het medisch onderzoek begon. Deze twee momenten konden samenvallen als de patiënt zich onaangekondigd aan het praktijןkadres meldde en direct geholpen werd.

\section{Fase 3}

Deze fase geeft de tijd aan die verstreek vanaf het moment van onderzoek door de huisarts tot aan het ogenblik waarop de patiënt zich aan de balie van de EHBO van het Academisch Ziekenhuis Maastricht meldde. Op dat moment begon de tijdsmeting in het ziekenhuis.

\section{Fase 4}

Met fase 4 wordt de tijd voorgesteld, die verliep vanaf het moment van binnenkomst op de EHBO tot aan het ogenblik waarop de dienstdoende arts daar met zijn onderzoek begon. Fase 4 stelt eigenlijk de wachttijd op de EHBO voor.

\section{Fase 5}

Deze fase geeft het tijdsverloop aan bij de geopereerde patiënten vanaf het moment waarop het onderzoek op de EHBO begon tot aan het ogenblik waarop de narcose werd ingeleid (biilage $3 a$ ).

\section{Fase 6}

In fase 6 wordt de duur gemeten vanaf het moment van onderzoek op de EHBO (of het moment waarop de operatie begon) tot aan de datum van ontslag uit het ziekenhuis of overlijden in het ziekenhuis. Omdat de tijdsmeting hier niet in directe relatie stond tot vroegdiagnostiek en snel therapeutisch handelen was een grotere nauwkeurigheid dan meting in dagen niet modig. Eigenlijk is fase 6 slechts weergegeven voor de volledigheid. De duur van de poliklinische controles is helemaal niet gemeten omdat er een té grote discrepantie bestond tussen de relevantie van de uitkomsten en de moeite die het zou kosten om deze uitkomsten te verzamelen. Om dezelfde reden is het moment waarop de einddiagnose werd gesteld (ergens in fase 6) niet gemeten.

De tijd werd als volgt gemeten: het tijdstip waarop de buikpijn begon is bepaald door de 
patiënt en/of zijn omgeving. Alle andere tijdstippen zijn door artsen of assistentie (hulpvraag huisarts, binnenkomst EHBO) vastgelegd. Ervan uitgaande dat jedereen geprobeerd heeft zo nauwkeurig mogelijk te ziin is het natuurlijk duidelijk dat de tijdsmeting door de (vaak doodzieke) patiënt en/of zijn ongeving als de minst accurate moet worden beschouwd. De mate van accuratesse bij de betrokkenen is niet bekend.

Bij één gegeven was het mogelijk te vergelijken omdat het zowel op het huisartsen- als op het specialistenformulier was ingevuld: de duur van de klacht (bijlage 2 en 3 ). Het bleek dat $91 \%$ van de tijdsduur precies met elkaar overeenkwam en dat bij de rest er nooit meer dan één uur verschil was. In aanmerking moet dan hierbij worden genomen dat er op het geheugen van de patiënt afgegaan is. Dit pleit voor zowel de accuratesse van de patiënt als die van de artsen.

In de nu volgende paragrafen wordt het tijdsverloop binnen de totale onderzoekspopulatie, het tijdsverloop in groep A (zelfverwijzers), in groep E (door huisarts verwezen en voorzien van een correct ingevuld huisartsenformulier) en in de groepen $C, D$ en $\mathbf{E}$ als samengestelde groep (door een huisarts verwezen, figuur 8.2) bestudeerd. Groep B (door andere dan huisartsen verwezen) blijft door zijn geringe grootte (3l casus) als groep apart buiten beschouwing. Van de verschillende fasen wordt vastgesteld hoe zij zich tot elkaar verhielden. Op deze wijze kan een beeld worden verkregen over hoe lang het duurde: de fase totdat de patiënt zich tot de huisarts wendde, het wachten op de operatie enzovoort.

Bestudering van de totale populatie ( 1100 casus) levert een overall-beeld op. Omdat niet in alle gevallen het beleid door de huisarts op een adequate wijze werd vastgelegd (figuur 8.2) is de aandacht hier in hoofdzaak gericht op de tijd die in het ziekenhuis verstreek: de tijd die verliep nádat de patiënt zich aan de balie van de EHBO meldde.

Bij de bespreking van de groepen $A$ (zelfverwijzers) en C, D en $E$ (door huisarts verwezen) ligt de nadruk op de tijd die hieraan voorafging, in deze studie verder de "pre-klinische fase" genoemd. De resultaten bij groep A worden vergeleken met die van groep C, D en E. Op deze wijze kan onderzocht worden of het in het algemeen korter of langer duurde voordat een zelfverwijzer na het ontstaan van zijn klacht medische hulp inriep, in vergelijking tot de groep die door een huisarts naar de EHBO was verwezen.

Groep E (op adequate wijze verwezen) wordt nog eens apart belicht. De fasen 1, 2 en 3 zijn als afzonderlijke fasen immers uitsluitend aan deze groep te bestuderen.

Vervolgens worden binnen het huisartsgeneeskundig handelen de begrippen waarneming, (spoed)visite en (spoed) consult gerelateerd aan tijdsverloop.

Tenslotte worden de fasen 1 tot en met 5 van de meest voorkomende einddiagnoses (Non Specific Abdominal Pain, appendicitis) aan een nader onderzoek onderworpen. De nadruk komt te liggen op de verschillen tussen de wel en niet geperforeerde appendicitiden met het oog op mogelijk delay.

\subsection{Tijdsverloop in de totale populatie (1100 casus)}

Dit tijdsverloop wordt per fase uitgedrukt in gemiddelde duur (rekenkundig gemiddelde, berekend volgens de onverkorte methode, bij individuele waarnemingsuitkomsten) en in 
frequentieverdeling van de gemiddelde duur. Op deze wijze wordt een duidelijk beeld over het tijdsverloop verkregen.

De fasen 1, 2 en 3 kunnen natuurlijk niet afzonderlijk in tijd worden uitgedrukt omdat binnen de totale populatie niet alle patiënten door een huisarts werden verwezen, maar eveneens omdat niet altijd het huisartsenformulier correct werd ingevuld (figuur 8.2). De eerste drie fasen worden dan ook samengevoegd tot de pre-klinische fase.

Figuur 9.2 geeft de fasen binnen de totale onderzoekspopulatie weer met daarbij vermeld de gemiddelde duur ervan:

fase 4 (wachttijd EHBO)

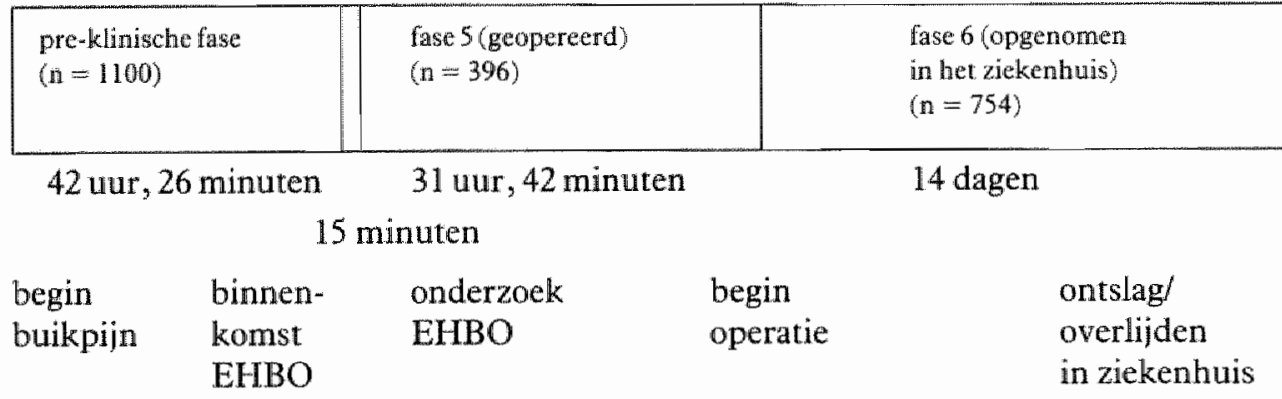

Figuur 9.2

Gemiddelde duur van de fasen. Totale populatie.

Tabel 9.3 geeft de frequentieverdeling weer van de gemiddelde duur van de pre-klinische fase en de fasen 4 en 5 :

Tabel 9.3

Frequentieverdeling van de gemiddelde duur van de verschillende fasen. Totale populatie.

\begin{tabular}{lccc}
\hline Duur & $\begin{array}{l}\text { Pre-klinische } \\
\text { fase } \\
\text { Aanral (\%) }\end{array}$ & Fase 4 & Fase 5 \\
\hline$\leqslant 10^{\prime}$ & -- & Aantal $(\%)$ & Aantal $(\%)$ \\
$11-20^{\prime}$ & $3(0,2)$ & $406(36,9)$ & $1(0,2)$ \\
$21-30$ & $11(1,0)$ & $485(44,1)$ & $19(4,7)$ \\
$31-45^{\prime}$ & $3(0,2)$ & $140(12,7)$ & $47(11,8)$ \\
$46-60$ & $17(1,5)$ & $32(2,9)$ & $52(13,1)$ \\
$1-2$ uur & $57(5,2)$ & $9(2,1)$ & $34(8,5)$ \\
$2-4$ uur & $125(11,4)$ & $5(0,4)$ & $35(8,8)$ \\
$4-8$ uur & $136(12,4)$ & -- & $21(5,3)$ \\
$8-12$ uur & $129(11,7)$ & -- & $16(4,0)$ \\
$12-24$ uur & $165(15,0)$ & -- & $31(8,1)$ \\
24 uur-1 week & $351(31,9)$ & -- & $41(10,3)$ \\
$>1$ week & $103(9,4)$ & -- & $53(13,3)$ \\
Totaal & $1100(100)$ & $1100(100)$ & $46(11,6)$ \\
\hline
\end{tabular}


Fase 6 is in tabel 9.3 wegens te geringe relevantie (paragraaf 9.1) buiten beschouwing gelaten. Opvallend in figuur $9.2 \mathrm{en}$ tabel 9.3 is de vrij lange duur van de pre-klinische fase. In paragraaf 9.7 , tijdens de discussie, wordt hierop teruggekomen. De wachttijd op de EHBO (fase 4) is de kortste van alle: $36,9 \%$ wachtte 10 minuten of minder. Een wachttijd langer dan een uur was incidenteel.

Fase 5 wordt qua tijdsduur bepaald door een aantal zaken. De diagnostische procedure is vaak nog in volle gang en er moet natuurlijk pre-operatief gescreend worden. Bij een kwart van de geopereerde casus duurde het langer dan 24 uur voordat er tot operatief ingrijpen werd overgegaan (tabel 9.3), bij meer dan de helft duurde het minder dan 4 uur. Uit bijlage 33 blijkt dat patiënten met aandoeningen waarvoor snel chirurgisch ingrijpen over het algemeen vereist is, zoals appendicitis, perforatie van een ulcus pepticum en vasculaire aandoeningen, voor het grootste gedeelte binnen 5 uur geopereerd werden. Daar tegenover staat echter dat bij bijna de helft van de geperforeerde appendicitiden fase 5 langer duurde dan 5 uur. Nadere specificatie is te vinden in de bijlagen 27 tot en met 34 .

\subsection{Groep A (zelfverwijzers, 160 casus)}

Op deze plaats is groep A vooral van belang vanwege haar pre-klinische fase. In paragraaf 8.10 is deze groep zelfverwijzers al uitgebreid aan de orde geweest. Figuur 9.4 geeft de gemiddelde duur van de fasen weer:

fase 4 (wachttijd EHBO)

\begin{tabular}{|l|l|l}
\hline $\begin{array}{l}\text { pre-klinische fase } \\
(\mathrm{n}=160)\end{array}$ & $\begin{array}{l}\text { fase 5(geopereerden) } \\
(\mathrm{n}=30)\end{array}$ & $\begin{array}{l}\text { fase 6 (opgenomen } \\
\text { in het zickentuis) } \\
(\mathrm{n}=72)\end{array}$ \\
\hline 34 uur, 48 minuten & 47 uur, 20 minuten & 13 dagen
\end{tabular}

15 minuten

$\begin{array}{lllll}\text { begin } & \text { binnen- } & \text { onderzoek } & \text { begin } & \text { ontslag/ } \\ \text { buikpijn } & \text { komst } & \text { EHBO } & \text { operatie } & \text { overlijden } \\ & \text { EHBO } & & & \text { in ziekenhuis }\end{array}$

Figuur 9.4

Gemiddelde duur van de fasen. Groep A. 
Tabel 9.5 geeft de frequentieverdeling van de gemiddelde duur van de pre-klinische fase weer:

Tabel 9.5

Frequentieverdeling van de gemiddelde duur van de pre-klinische fase. Groep A.

\begin{tabular}{lc}
\hline Duur & $\begin{array}{c}\text { Pre-klinische fase } \\
\text { Aantil }(\%)\end{array}$ \\
\hline$\leq 10^{\prime}$ & -- \\
$11-20^{\prime}$ & -- \\
$21-30^{*}$ & $4(2,5)$ \\
$31-45^{\prime}$ & -- \\
$46-60^{\prime}$ & $4(2,5)$ \\
$1-2$ uur & $18(11,2)$ \\
$2-4$ uur & $30(18,7)$ \\
$4-8$ uur & $21(13,1)$ \\
$8-12$ uur & $16(10,0)$ \\
$12-24$ uur & $16(10,0)$ \\
24 uur - 1 week & $36(22,5)$ \\
$>1$ week & $15(9,4)$
\end{tabular}

Totaal

$160(100)$

Omdat het in deze paragraaf vooral gaat om de pre-klinische fase zijn de fasen 4 tot en met 6 in tabel 9.5 buiten beschouwing gelaten.

De pre-klinische fase van groep A duurde gemiddeld ruim 71/2 uur korter dan die van de totale populatie (figuur 9.2). In vergelijking tot de totale populatie was er een gelijk percentage casus waarbij de pre-klinische fase langer duurde dan een week maar een groter percentage waarbij de pre-klinische fase korter duurde dan 4 uur(vergelijk tabel 9.3 met tabel 9.5).

Qua bemoeienis door een huisarts is groep A in te dellen in 2 subgroepen:

subgroep 1: zelfverwijzing zonder enig voorafgaand onderzoek door een huisarts; subgroep 2: zelfverwijzing met voorafgaand onderzoek door een of meer huisartsen gedurende de week voor binnenkomst op de EHBO.

Voor deze subgroepen wordt de gemiddelde duur van de pre-klinische fase als volgt: 
Tabel 9.6

Gemiddelde duur pre-klinische fase voor subgroep 1 en 2 .

Groep A.

Pre-klinische fase

Gemiddelde duur

Subgroep $1(n=139)$

31 uur, 36 minuten

Subgroep $2(n=21)$

56 uur, 10 minuten

Totaal $\quad(n=160)$

34 uur, 48 minuten

Opvallend maar niet verbazingwekkend, is de langere gemiddelde duur van de pre-klinische fase voor subgroep 2. Bijna de helft van deze subgroep kwam op de EHBO na een klachtenduur van meer dan 24 uur $(47,7 \%)$. Voor subgroep 1 was dit percentage $29,4 \%$ (bijlage 35).

\subsection{Groep C, D en E (door een huisarts verwezen, 909 casus)}

Bij deze samengestelde groep wordt in hoofdzaak naar de pre-klinische fase gekeken. Dit is van belang omdat deze fase vergeleken moet worden met die van groep $A$ (zelfverwijzers). Figuur 9.7 geeft het gemiddelde tijdsverloop weer van de fasen in de samengestelde groep C, D en E:

fase 4 (wachtuijd EHBO)

\begin{tabular}{|l|l|l}
\hline $\begin{array}{l}\text { pre-klinische fase } \\
(\mathrm{n}=909)\end{array}$ & $\begin{array}{l}\text { fase 5 (geopereerden) } \\
(\mathrm{n}=365)\end{array}$ & $\begin{array}{l}\text { fase 6 (opgenomen } \\
\text { in het zickenhuis) } \\
(\mathrm{n}=659)\end{array}$ \\
\hline 43 uur, 42 minuten & 30 uur, 24 minuten & 14 dagen
\end{tabular}

15 minuten

$\begin{array}{lllll}\text { begin } & \text { binnen- } & \text { onderzoek } & \text { begin } & \text { ontslag/ } \\ \text { buikpijn } & \text { komst } & \text { EHBO } & \text { operatie } & \text { overlijden } \\ & \text { EHBO } & & & \text { in ziekenhuis }\end{array}$

Figur 9.7

Gemiddelde duur van de fasen. Groep C, D en E als samengesteldè groep.

Tabel 9.8 geeft de frequentieverdeling weer van de gemiddelde duur van de pre-klinische fase: 
Tabel 9.8

Frequentieverdeling van de gemiddelde duur van de pre-klinische fase. Groep $C, D$ en $E$ als samengestelde groep.

\begin{tabular}{lc}
\hline Duur & $\begin{array}{c}\text { Pre-klinische fase } \\
\text { Aantal }(\%)\end{array}$ \\
\hline$\leqslant 10^{\prime}$ & -- \\
$11-20^{*}$ & $3(3,0)$ \\
$21-30^{*}$ & -- \\
$31-45^{*}$ & $3(3,0)$ \\
$46-60^{*}$ & $10(1,1)$ \\
$1-2$ uur & $39(4,2)$ \\
$2-4$ uur & $94(10,3)$ \\
$4-8$ uur & $111(12,2)$ \\
$8-12$ uur & $108(11,9)$ \\
$12-24$ uur & $148(16,3)$ \\
24 uur -1 week & $307(33,8)$ \\
$>1$ week & $86(9,4)$ \\
\hline Totaal & $909(100)$ \\
\hline
\end{tabular}

Bij vergelijking van de gemiddelde duur van de pre-klinische fase van groep C, Den E met die van groep A valt de kortere duur (bijna 9 uur) op van deze fase bij groep A (vergelijk figuur 9.7 met figuur 9.4). Qua aantal onderzoeken door de huisarts is groep C, D en E evenals groep A (zelfverwijzers) in te delen in 2 subgroepen:

subgroep 1: na eenmalig onderzoek door een huisarts direct naar de EHBO verwezen; subgroep 2: gedurende de week voorafgaande aan de verwijzing een of meerdere malen door een of meer huisartsen in verband met dezelfde buikklachten onderzocht.

De gemiddelde duur van de pre-klinische fase is voor beide subgroepen weergegeven in tabel 9.9:

Tabel 9.9

Gemiddelde duur van de pre-klinische fase voor subgroep 1 en 2. Groep C, D en E.

Groep C, D en E

Gemiddelde duur pre-klinische fase

Subgroep $1(\mathrm{n}=610)$

36 uur, 20 minuten

Subgroep $2(n=299)$

58 uur, 42 minuten

Totaal $\quad(\mathrm{n}=909)$

43 uur, 42 minuten 
Vergelijking van tabel 9.6 met tabel 9.9 toont dat bij groep A beide subgroepen korter van gemiddelde duur zijn dan die van groep $\mathrm{C}, \mathrm{D}$ en $\mathrm{E}$.

\subsection{Groep E (op afgesproken manier verwezen door huisarts, 564 casus)}

De fasen 1, 2 en 3 (paragraaf 9.1) kunnen slechts apart worden bestudeerd bij groep $\mathbb{E}$ (huisartsenformulier correct ingevuld aanwezig). Ook de duur van de (spoed)visites en (spoed)consulten kunnen slechts bij deze groep worden vastgesteld. Figuur 9.10 geeft de gemiddelde duur aan van de afzonderlijke fasen 1,2 en 3 in groep E:

\begin{tabular}{|c|c|c|}
\hline fase 1 & fase 2 & fase 3 \\
\hline 40 uur, 6 minuten & 1 uur & $\begin{array}{l}1 \text { uur, } \\
36 \text { minuten }\end{array}$ \\
\hline
\end{tabular}

begin

buikpijn hulpvraag

huisarts onderzoek binnenhuisarts komst

EHBO

Figurur 9.10

Gemiddelde duur van de fasen 1, 2 en 3. Groep E.

De frequentieverdeling van deze gemiddelde tijden zijn te zien in tabel 9.11:

Tabel 9.11

Frequentieverdeling van de gemiddelde duur van de fasen 1, 2 en 3. Groep E.

\begin{tabular}{lccc}
\hline Duur & Fase 1 & \multicolumn{1}{c}{ Fase 2 } & \multicolumn{1}{l}{ Fase 3 } \\
& Aantal $(\%)$ & Aantal $(\%)$ & \multicolumn{1}{c}{ Aantal $(\%)$} \\
\hline$\leqslant 10^{\prime}$ & -- & $201(35,6)$ & $2(0,4)$ \\
$11-20^{\prime}$ & $1(0,2)$ & $107(18,9)$ & $55(9,7)$ \\
$21-30^{\prime}$ & $7(1,4)$ & $57(10,1)$ & $75(13,3)$ \\
$31-45^{\prime}$ & $3(0,5)$ & $18(3,2)$ & $80(14,2)$ \\
$46-60^{\prime}$ & $11(4,9)$ & $24(4,2)$ & $121(21,4)$ \\
$1-2$ uur & $30(5,3)$ & $66(11,7)$ & $164(29,0)$ \\
$2-4$ uur & $59(10,4)$ & $64(11,3)$ & $48(8,5)$ \\
$4-8$ uur & $76(13,4)$ & $22(3,9)$ & $13(2,3)$ \\
$8-12$ uur & $63(11,1)$ & $5(0,9)$ & $4(0,8)$ \\
$12-24$ uur & $89(15,8)$ & -- & $1(0,2)$ \\
24 uur-1 week & $182(32,2)$ & -- & $1(0,2)$ \\
$>1$ week & $43(7,6)$ & -- & - \\
\hline Totaal & $564(100)$ & $564(100)$ & $564(100)$ \\
\hline
\end{tabular}


Bij figuur 9.10 springt meteen de relatief veel langere gemiddelde duur van fase 1 in het oog. Meer dan eenderde (39,8\%) van groep E stelde de laatste hulpvraag vóór verwijzing pas na meer dan 24 uur buikpijn te hebben gehad (tabel 9.11). Hieronder bevonden zich onder meer 7 geperforeerde appendicitiden en 4 geperforeerde ulcera peptica(bijlage 41). Tabel 9.12 laat de gemiddelde duur zien van fase 1 bij verwijzing door de eigen huisarts en tijdens waarneming:

Tabel 9.12

Gemiddelde duur van fase 1 bij verwijzing door de eigen huisarts en tijdens waarneming. Groep E.

$\begin{array}{ll}\text { Eigen huisarts }(n=413) & 45 \text { uur, } 15 \text { minuten } \\ \text { Waarnemer } \quad(n=151) & 26 \text { uur, } 10 \text { minuten }\end{array}$

Totaal

$(\mathrm{n}=564)$

40 uur, 6 minuten

De frequentieverdeling van deze gemiddelden is te zien in bijlage 37 . Wat onder het begrip waarneming verstaan moet worden is uitgelegd in paragraaf 8.11 . Uit tabel 9.12 blijkt dat er een fors tijdsverschil bestond tussen onderzoek door de eigen huisarts en waarneming voor wat betreft de gemiddelde duur van fase 1 . Gerelateerd aan de bevindingen in paragraaf $8.11 \mathrm{komt}$ dit probleem gedurende de discussie nog aan de orde.

Fase 2, de tijd die verliep tussen de hulpvraag aan de huisarts en effectuering hiervan, kon eindigen in een consult, een visite, een spoedconsult of een spoedvisite. Deze begrippen zijn eveneens al verduidelijkt in paragraaf 8.11. De gemiddelde duur van fase 2 per soort verrichting wordt getoond in tabel 9.13:

Tabel 9.13

Gemiddelde duur van fase 2 per soort verrichting bij waarneming en bij onderzoek door de eigen huisarts. Groep E.

\begin{tabular}{|c|c|c|c|}
\hline Soot verrichting & $\begin{array}{l}\text { Gemiddelde duur } \\
\text { Wan fase } 2 \text { bij } \\
\text { warneming }\end{array}$ & $\begin{array}{l}\text { Gemiddelde duur } \\
\text { van fase } 2 \text { bii } \\
\text { onderzoek } \\
\text { eigen huisarts }\end{array}$ & $\begin{array}{l}\text { Gemiddelde duur } \\
\text { van fase } 2 \\
\text { totaal }\end{array}$ \\
\hline Consult $\quad(n=136)$ & 1 uur & 35 min. & $40 \mathrm{~min}$. \\
\hline$(n=190)$ & 1 uur, 40 min. & 2 uur, $15 \mathrm{~min}$. & 2 uur, $10 \mathrm{~min}$. \\
\hline Spoedconsult $(n=107)$ & $10 \mathrm{~min}$ & $25 \mathrm{~min}$ & $18 \mathrm{~min}$. \\
\hline Spoedvisite $\quad(\mathrm{n}=131)$ & $12 \mathrm{~min}$ & $24 \mathrm{~min}$. & $20 \min$. \\
\hline$(n=564)$ & $50 \mathrm{~min}$. & 1 uur, $6 \mathrm{~min}$. & 1 uur \\
\hline
\end{tabular}


Figuur 9.14 geeft de verdeling weer van fase 2 in tijdsclusters per soort verrichting (Groep E):

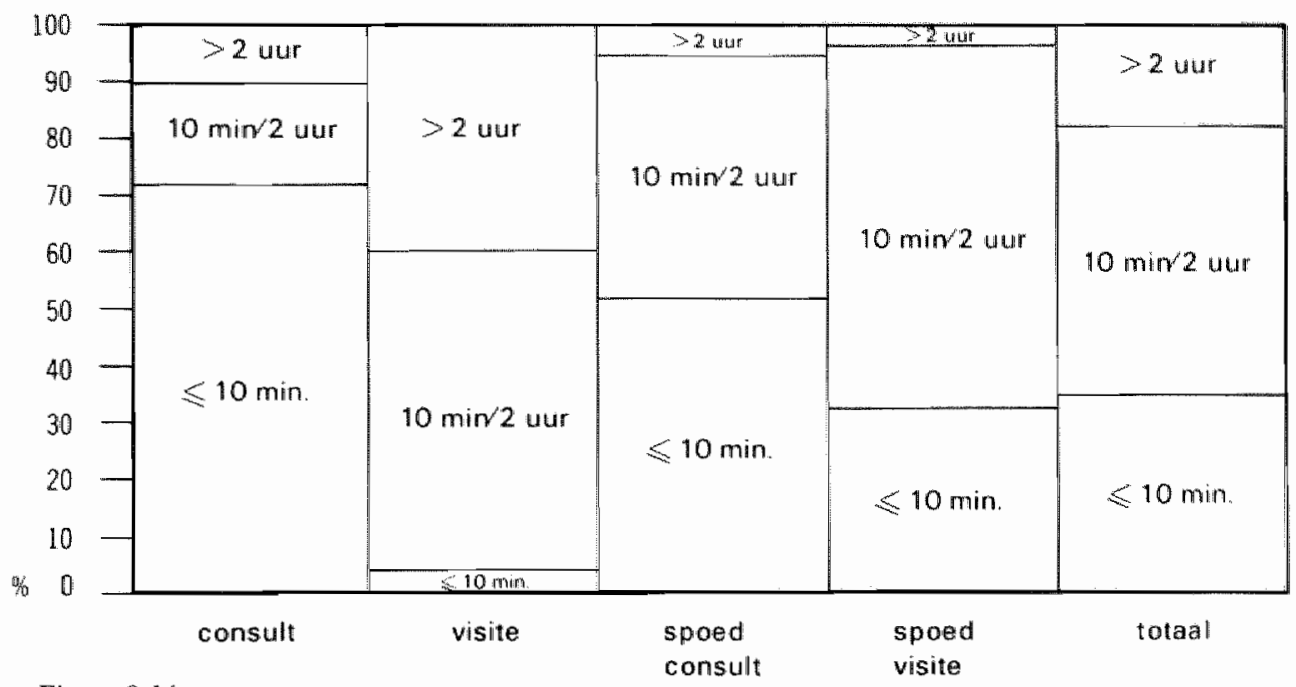

Figuur 9.14

Verdeling van fase 2 in tiidsclusters per soort verrichting (Groep E),

Uit figuur 9.14 komt naar voren dat procentueel meer gewone consulten binnen de 10 minuten tot stand kwamen dan de als "spoed" (paragraaf 8.11) geëriketteerde consulten. Eerder is al opgemerkt dat het moment van de hulpvraag kon samenvallen met het moment van onderzoek als een patiënt zich onaangekondigd op het praktijkadres meldde en direct geholpen werd. Verder valt op in figuur 9.14 dat bij de spoedgevallen een aantal casus lang op behandeling heeft moeten wachten: vier spoedconsulten vergden meer dan 2 uur wachttijd ( $2 \mathrm{x}$ Non Specific Abdominal Pain, $\mathrm{lx}$ appendicitis non perforata, $\mathrm{lx}$ pancreatitis).

Fase 3 duurde gemiddeld 1 uur en 36 minuten (figuur 9.10). Fase 3 geeft de tijd aan die het kostte voordat de verwezen patiënt zich meldde op de EHBO. Een patiënt kon per ambulance of per eigen gelegenheid naar de EHBO gaan. Tabel 9.15 geeft de gemiddelde tijd hiervan weer:

Tabel 9.15

Gemiddelde duur wan fase 3 per soort vervoer. Groep E.

Ambulance

Eigen vervoer/open baar vervoer
1 uur, 30 minuten

1 uur, 40 minuten

1 uur, 36 minuten 
Uit tabel 9.15 blijkt dat de manier van vervoeren nauwelijks de gemiddelde duur van fase 3 beinvloedde. Bijlage 38 laat de frequentieverdeling zien van deze gemiddelde tijden. Nader onderzoek leert dat $23,4 \%$ van de casus van groep $E$ zich binnen een half uur na verwijzing op de EHBO meldde, $11,9 \%$ deed hier langer over dan 2 uur ( $3 \mathrm{x}$ appendicitis perforata, $6 \mathrm{x}$ appendicitis non perforata, $4 \mathrm{x}$ obstructie dunne darm, $1 \mathrm{x}$ perforatie ulcus pepticum).

\subsection{Tijdsverloop bij de einddiagnoses Non Specific Abdominal Pain en appendicitis (Groep E).}

Omdat de categorieën einddiagnoses Non Specific Abdominal Pain en appendicitis numeriek eigenlijk de grootste waren (tabell 8.7 en bijlage 9), verdiemen de verschillendle fasen bij deze einddiagnoses extra belichting. Met name de onderlinge verhouding van de gelijknamige fasen lijkt erg interessant.

In deze paragraaf worden de fasen 1 tot en met 5 bestudeerd. Fase 6 blijft buiten beschouwing in verband met de al eerder genoemde geringe relevantie ervan met betrekking tot vroegdiagnostiek en snel therapeutisch handelen.

Het beleid door de huisartsen in fasen afzonderlijk kan voor wat betreft de einddiagnose Non Specific Abdominal Pain en appendicitis uitsluitend bijgroep $\mathrm{E}$ worden bestudeerd.

In figuur 9.16 is het gemiddelde tijdsverloop van de fasen 1 tot en met 5 te zien voor de einddiagnoses Non Specific Abdominal Pain, appendicitis perforata, appendicitis non perforata en het appendiculair infiltraat.
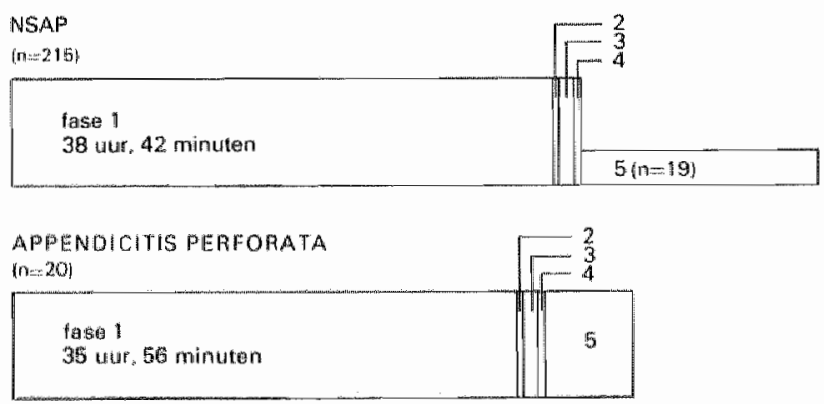

APENDICITIS

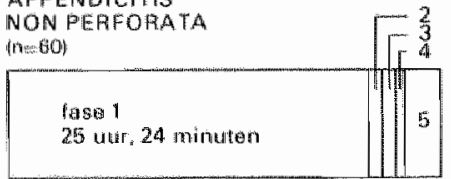

APPENOICULAIT INNILTRAAT $(n)=190$

tesa 1

52 uur. 54 minulat fase 2: 36 minuten fase 3: 1 uur, 24 minuter fase 4: 12 minuten fase 5: 16 uur, 36 minutem

fase 2: 36 minuten fase 3: 1 uur, 24 minuten fase 4: 13 minuten fase $5: 6$ uur, 42 minuten

fase 2 . 1 uur 12 minuten fase 3: 1 utur, 18 minuten fase 4:14 minuten fase 5: 3 uur, 40 minuten

fase 2. 1 uur, 25 minuten lase 3. 1 vur, 24 minuten fase 4: 15 minuten fase 5: 150 un $5 \ln -3)$

Figuur 9.16

Gemiddeld tijdsverloop van de fasen 1 tot en met 5 voor de einddiagnoses Non Specific Abdominal Pain, appendicitis perforat $a_{3}$ appendicitis non perforata en appendiculair infiltrat. Groep $\mathbf{E}$. 
De frequentieverdeling van het gemiddelde tijdsverloop van de fasen $1,2,3$ en 5 is te zien in de bijlagen $41,42,43$ en 44 .

Van de in deze paragraaf bestudeerde casus werd $28,3 \%$ gedurende de week voorafgaande aan de verwijzing al eens eerder voor dezelfde klachten door een huisarts onderzocht (bijlage 25). De samenhang hiervan met de gemiddelde tijdsduur van de fasen 1 is te zien in tabel 9.17:

Tabel 9.17

Gemiddelde duur fase 1 van de casus die wel en die niet gedurende de week voorafgaande aan de verwijzing al eens eerder door een huisarts waren onderzocht per categorie einddiagnose. Groep E.

Einddiagnose
Gemididelde duur fase 1 voor de meteen na eerste onderzoek verwezen casus
Gemiddelde dun fase 1 voor de vaker door een huisarts onderzochte casus

$\begin{array}{ll}34 \text { uur, 58 minuten } & 50 \text { uur, 10 minuten } \\ 35 \text { uur, 55 minuten } & 36 \text { uur, 18 minuten } \\ 19 \text { uur, 42 minuten } & 36 \mathrm{uur}, 15 \text { minuten } \\ 40 \text { uur, 30 minuten } & 88 \mathrm{uur}\end{array}$

Uit tabel 9.17 bljkt dat de gemiddelde duur van fase 1 bij die casus welke meer dan én keer door een huisarts voor dezelfde klacht waren onderzocht bij alle in de tabel genoemde categorieën einddiagnoses langer was.

Achtereenvolgens worden nu de in figuur 9.16 getoonde fasen besproken. Bij elke fase wordt ter verduidelijking een situatietekening gegeven.

\section{Fase 1}

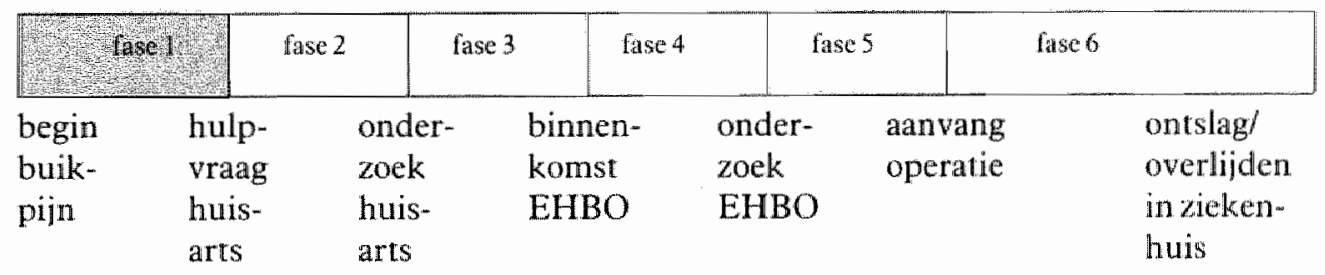

Figunr 9.18

Plats van fase 1 in het zilekteverloop.

Fase 1 was ten opzichte van alle andere fasen gemiddeld de langste (op fase 5 van het appendiculair infiltraat na, maar dit betrof slechts 3 casus). Bij vergelijking van de fasen 1 onderling blijkt dat fase 1 gemiddeld het kortste was bij die casus welke uiteindelijk de 
diagnose appendicitis non perforata kregen. Fase 1 duurde gemiddeld het langste bij het peri-appendiculaire infiltraat (figuur 9.16). Uit tabel 9.19 blijkt dat er behoorlijk wat casus waren die een fase 1 hadden langer durend dan 12 uur:

Tabel 9.19

Casus waarbij fase 1 langer duurde dan 12 uur naar percentagegrootte. Groep E.

Einddiagnose

Fase $]>12$ uur

Appendiculair infilltraat

$$
(\mathrm{n}=19)
$$

$78,7 \%$

Appendicitis perforata

$(n=20)$

$65,0 \%$

Non Specific Abdominal Pain $(n=215)$

$52,9 \%$

Appendicitis non perforata $\quad(n=60)$

$47,8 \%$

Bij de gecompliceerde appendicitiden was het percentage casus dat een fase 1 had die meer dan 12 uur duurde, het hoogste.

\section{Fase 2}

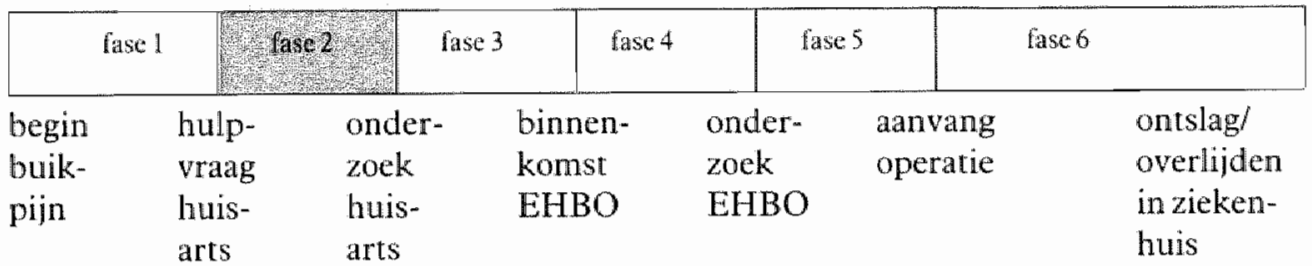

Figun: 9.20

Plaats van fase 2 in het ziekteverloop.

Fase 2 duurde bij de in figuur 9.16 getoonde categorieën einddiagnoses gemiddeld veel korter dan fase 1 . Slechts 40 casus ( $12,7 \%$ van de genoemde einddiagnoses) hoefden langer dan 2 uur op hulp door een huisarts te wachten (bijlage 42).

\section{Fase 3}

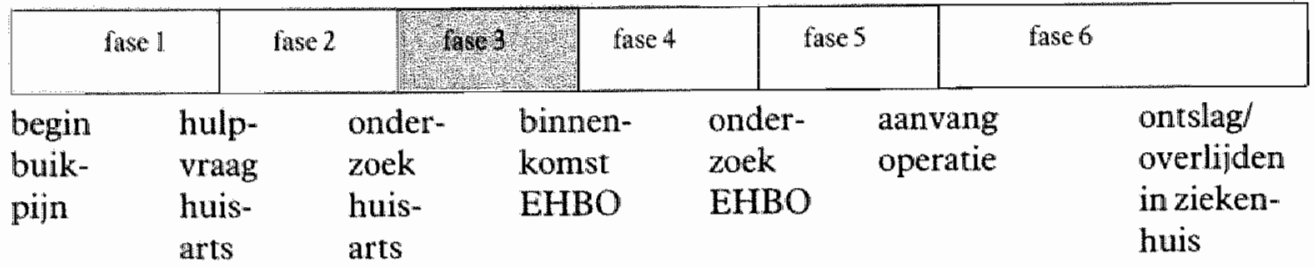

Figuur 9.21

Plaats van fase 3 in het ziekteverloop. 
Fase 3 was voor alle categoriën einddiagnoses bijna gelijk van gemiddelde duur. Uit bijlage 43 blijkt dat $45 \%$ van de patiënten met geperforeerde appendicitiden er langer dan een uur over deden om na onderzoek door een huisarts op de EHBO te komen. Voor het appendiculair infiltraat was dit $47,7 \%$, bij de Non Specifical Abdominal Pain $51,3 \%$ en bij de ongeperforeerde appendicitis $53,2 \%$.

\section{Fase 4}

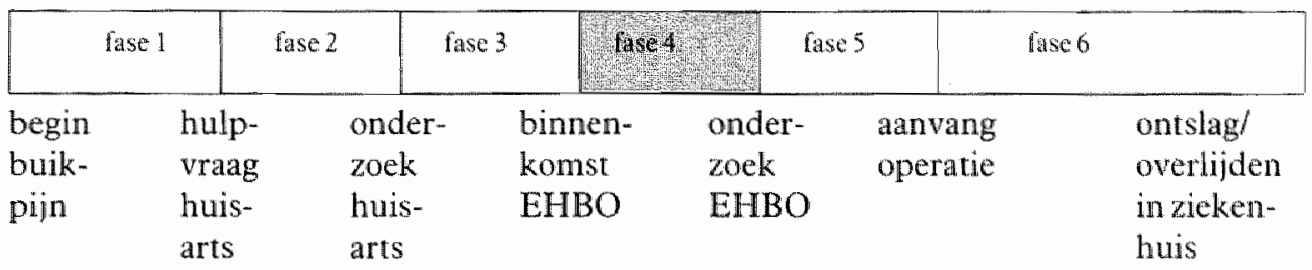

Figur 9.22

Plaats van fase 4 in het ziekteverloop.

De duur van fase 4 varieerde bij de vier einddiagnoses in figuur 9.16 van 12 tot 15 minuten gemiddeld. Het was hierdoor gemiddeld de kortste fase. Slechts én patiënt met appendicitis heeft om onbekende reden langer dan een uur moeten wachten op de EHBO.

\section{Fase 5}

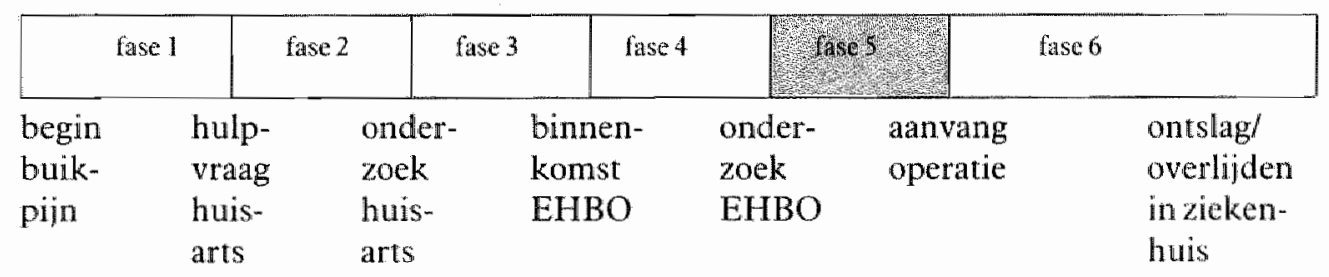

Figuur 9.23

Plaats wan fase 5 in het ziekteverloop.

De duur van fase 5 wordt bepaald door een aantal factoren zoals twijfel aan de diagnose en de oorzaak tot opereren, pre-operatieve screening, enzovoort. Opvallend is dat deze fase bii de geperforeerde appendicitiden gemiddeld bijna 2 maal zo lang duurde alls bij de ongeperforeerde appendicitiden. Uit biilage 44 blijkt daarbij dat bij $75 \%$ van de perforaties, en bij slechts $34 \%$ van de niet geperforeerde appendicitiden, fase 5 langer duurde dan 3 uur. Bij de 2 geopereerde appendiculaire infiltraten duurde fase 5 zelfs langer dan een week!

Bij onderling vergelijken van de totale gemiddelde ziekteduur tot en met fase 5 valt op dat die gemiddelde duur bij de geperforeerde appendicitiden ruim 12 uur langer was dan die bij de ongeperforeerde appendicitiden (figuur 9.16). Met name de fasen 1 en 5 waren voor dit tijdsverschil verantwoordelijk. 
Omdat bovenstaande bevindingen alleen zijn gedaan in groep E (die overigens de meeste, $71 \%$, appenditicitiden bevat) zijn de fasen 1 tot en met 4 en fase 5 van alle appenditicitiden in de Acute Buik Analyse nog eens naast die van groep E gezet. Het resultaat is te zien in figuur 9.24:

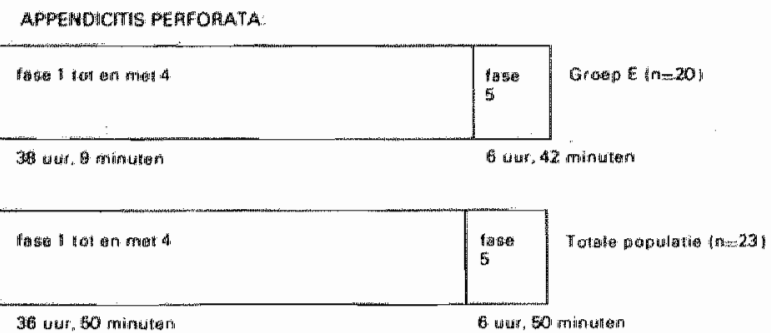

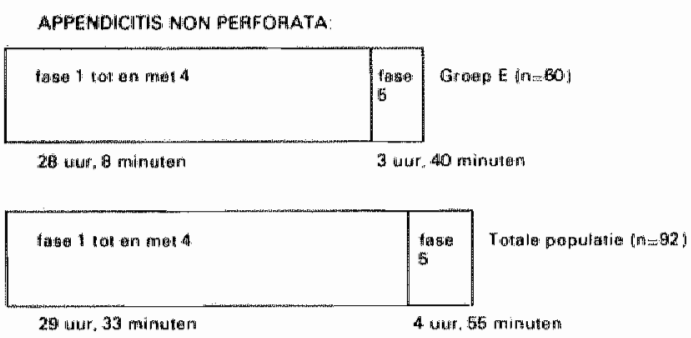

APPENIDICULAIR INFILTRAAT

\begin{tabular}{|c|c|c|c|}
\hline \multirow[t]{2}{*}{ finse 1 tol en :Thet 4} & \multicolumn{3}{|c|}{ Grotat $E$ in $=19$} \\
\hline & $\operatorname{tases} 5 n=2$ : & & \\
\hline 65 ustu, 58 mmin:Litan & 1:50 ULا & & \\
\hline \multirow[t]{2}{*}{ 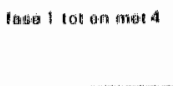 } & & \multicolumn{2}{|r|}{ Totatic pojulatiog $\{f-24 \mid$} \\
\hline & & fast $54 \mathrm{~m}=31$ & \\
\hline
\end{tabular}

Figuar 9.24

Tijdsverloop appendicitis. Groep E versus totale populatie.

Ook bii beschouwing van de totale populatie blijkt dat er een gemiddeld verschil in totale ziekteduur tot aan de operatie bestond van meer dan 9 uur tussen appendicitis perforata en appendicitis non perforata.

De reden dat niet alle geperforeerde appendicitiden op de afgesproken wijze waren verwezen was: Ix nalatigheid van de betrokken huisarts en $2 \mathrm{x}$ zelfverwijzing. De reden waarom niet alle ongeperforeerde appendicitiden op de afgesproken wijze waren verwezen was: $7 \mathrm{x}$ niet in eerste instantie aan een "acute buik" denken door de huisarts, $6 \mathrm{x}$ nalatigheid van de huisarts wat betreft het (correct) invullen van het onderzoeksformulier, $7 \mathrm{x}$ zelfverwijzing en $12 \mathrm{x}$ verwijzing door andere artsen dan de participanten aan de Acute Buik Analyse. Bij het infiltraat was de verdelling: $2 \mathrm{x}$ niet in eerste instantie aan een "acute buik" denken en $3 x$ verwijzing door niet-deelnemers aan de Acute Buik Analyse. 


\subsection{Discussie}

Omwille van het overzicht en voor alle duidelijkheid is deze paragraaf ingedeeld in vier sub-paragrafen:

1. totale onderzoekspopulatie;

2. groep $A$ versus groep $C, D$ en $E$;

3. groep $\mathrm{E}$;

4. Non Specific Abdominall pain, appendicitis.

\subsubsection{Totale onderzoekspopulatie}

Uit figuur 9.2 blijkt dat voor wat betreft de totale onderzoekspopulatie de pre-klinische fase niet alleen in gemiddelde duur op één na de langste was (de opnameduur, fase 6 , was langer) maar ook in absolute zin vrij lang duurde ( 42 uur, 16 minuten) als in aanmerking wordt genomen dat acute buikklachten vaak worden geassocieerd met spoed (paragraaf 2.2). Zelfs bij toch over het algemeen als zeer pijnlijk beschreven ziektebeelden zoals perforatie van een ulcus pepticum (Gail 1975, Fux 1979) duurde de pre-klinische fase nog altijd gemiddeld 19 uur en 42 minuten (bijlage 28)!

In de totale onderzoekspopulatie was fase 4 (wachttijd op de EHBO) in gemiddelde duur het kortste (15 minuten). Terwijl het niet ondenkbaar is dat door prioriteit van zeer zware calamiteiten (verkeersslachtoffers bijvoorbeeld) fase 4 op kan lopen bleek echter dat een wachttijd van meer dan 1 uur incidenteel was en dat de meeste casus binnen 20 minuten werden geholpen (tabel 9.3). Hoewel in sommige verhalen wel eens de indruk wordt gewekt dat lange wachttijden op de EHBO schering en inslag zijn, bleek dit bij acute buikklachten zeker niet zo te zijn. Of de gemiddelde duur van fase 5 (het tijdsverloop vanaf het moment van onderzoek op de EHBO tot aan de operatie) lang of niet lang moet worden genoemd is arbitrair. Tijdens deze fase moet er veel met de patiënt gebeuren: opname-procedure, afronding van de diagnostiek, pre-operatief onderzoek enzovoort.

\subsubsection{Groep A (zelfverwijzers) versus groep C, D en $\mathrm{E}$ (door huisarts verwezen)}

Bij vergelijking van figuur 9.4 met figuur 9.7 valt direct op dat de pre-klinische fase van groep A gemiddeld veel korter duurde dan die van groep C, D, en E. In paragraaf 8.12.3 is gedemonstreerd dat het percentage "niet zieken" (Knottmerus 1985) in groep A veel groter was dan in groep $\mathrm{C}, \mathrm{D}$ en $\mathrm{E}$. Mogelijk hangt de gevonden kortere gemiddelde tijdsduur hiermee samen (lagere tolerantie-drempel, vertrouwenskwestie ten aanzien van de huisarts). Vergelijken van tabel 9.6 met tabel 9.9 laat zien dat eerder onderzoek door een huisarts samenhing met een flink verlengde duur van de pre-klinische fase. De invloed van de bevindingen en adviezen van de huisarts zal hieraan zeker debet zijn geweest.

Geconcludeerd mag worden dat de zelfverwijzers zich over her algemeen sneller op de EHBO meldden dan de casus, welke door huisartsen werden verwezen. Vanwege de consequenties die het probleem heeft ten aanzien van het functioneren van zowel huisarts als EHBO (paragraaf 8.12.3) is het aan te bevelen, om nader onderzoek te doen naar de achtergronden van dit fenomeen. 


\subsubsection{Groep E (op afgesproken manier door huisarts verwezen)}

Bij bestuderen van de afzonderlijke fasen 1, 2 en 3 in groep $E$ (figuur 9.10) valt op de relatief veel langere gemiddelle duur van fase 1 (tijdswerloop moment begin klacht tor aan het stellen van de hulpvraag aan de huisarts). Een aantal geperforeerde appendicitiden en peptische ulcera hadden een fase 1 van meer dan 24 uur (bijlage 41 ).

Eerdere onderzoeken vóór verwijzing doen aan de relatief langste gemiddelde duur van fase 1 niets af (bijlage 36). Geconcludeerd mag worden dat de gemiddelde duur van fase 1 in groep $\mathbb{E}$ in hoofdzaak werd bepaald door uitstel door de patiënt zelf of zijn omgeving. In verband met het belang van de factor tijd voor de prognose van acute buikklachten zou het aanbeveling verdienen om nader onderzoek te doen naar de oorzaken van die langere gemiddelde duur van fase 1.

Fase 1 was bij een daarop volgend onderzoek door een waarnemend huisarts gemiddeld veel korter dan bij een onderzoek door de eigen huisarts(tabel 9.12). In paragraaf 8.12.4 is aannemelijk gemaakt dat het inroepen van huisartsgeneeskundige hulp bij acute buikklachten tijdens een waarneemsituatie uitgesteld werd. De resultaten uit tabel 9.12 steunen deze bevinding.

Het mag natuurlijk geen verbazing wekken dat spoedgevallen gemiddeld sneller tot medisch onderzoek leidden (fase 2) dan niet spoedeisende gevallen. Om onduidelijke redenen vergde realisatie van 6 van deze spoedhandelingen meer dan 2 uur tijd (figuur 9.14)! Het betrof hier verrichtingen, gedaan door de eigen huisarts. Zeer opmerkelijk is het verschil in gemiddelde tijdsduur die realiseren van de verschillende soorten verrichtingen kostte, tussen waarneming en onderzoek door de eigen huisarts (tabel 9.13). Dit kon allerlei oorzaken hebben:

1. andere mate van ernst waarmee de casus tijdens waarneming imponeerden;

2. hiermee in samenhang: het in de meeste gevallen tijdens waarneming onbekend zijn van huisartsen met de patiënten die hen raadpleegden;

3. andere werkdruk: een huisarts is op een gewone doordeweekse werkdag meer bezet (meer patiënten per tijdseenheid) waardoor het tot stand komen van een verrichting vertraagd kon worden.

Welbeschouwd is de tijd die het kostte voordat een spoedverrichting tot stand kwam erg kort te noemen (tabel 9.13). Het feit dat het gemiddeld maar 2 minuten langer duurde totdat een spoedvisite gerealiseerd werd in vergelijking tot een spoedconsult (waarbij in aanmerking moet worden genomen dat het moment van stellen van de hulpvraag samen kon vallen met het moment van onderzoek als een patiënt zich onaangekondigd met acute buikklachten op het praktijkadres meldde) pleit voor het werktempo van de huisartsen bij dit soort gevallen.

Na door een huisarts naar de EHBO te zijn verwezen zou het te verwachten zijn dat de patiënt zo spoedig mogelijk daarnaar toe gaat, per eigen gelegenheid of per ambulance (fase 3, figuur 9.10). De gemiddelde tijdsduur van fase 3 (1 uur, 36 minuten) is niet bepaald kort te noemen. Een aantal factoren heeft waarschijnlijk deze tijdsduur bepaald zoals de ernst waarmee het ziektebeeld imponeerde, de afstand tot het ziekenhuis en, niet 
in de laatste plaats, de duur van de diagnostische procedure, uitgevoerd door de huisarts. Om onbekende redenen duurde het langer dan 2 wur voordat 14 appendicitiden zich na onderzoek door de huisarts meldden op de EHBO (bijlage 43).

\subsubsection{Non Specific Abdominal Pain, appendicitis (einddiagnoses)}

In deze paragraaf worden slechts de fasen 1 tot en met 5 bediscussieerd. Vanwege de geringe relevantie ten aanzien van vroegdiagnostiek en snel therapeutisch beleid blifft fase 6 geheel buiten beschouwing. Allereerst wordt de gemiddelde duur van de fasen 1 tot en met 5 binnen de verschillende ziektebeelden bekeken en naast elkaar gezet. Daarna wordt de gemiddelde ziekteduur tot aan het moment van opereren per aparte categorie einddiagnose én de gemiddelde duur van de gelijknamige fasen binnen de verschillende categorieën einddiagnoses onderling vergeleken.

\section{Gemiddelde duur van fase 1 tot en met 5 (Groep E)}

Fase 1 (tijdsduur vanaf het begin van de buikpijn tot aan het moment waarop de laatste hulpvraag vóór verwijzing aan de huisarts werd gesteld) was in vergelijking tot de andere 4 fasen gemiddeld de langste (figuur 9.16). Als die casus, welke gedurende de week voorafgaande aan de verwijzing al eens eerder voor dezelfde buikklachten door een huisarts waren onderzocht, buiten beschouwing zouden worden gelaten dan zou fase 1 nog de langste in gemiddelde tijdsduur blijven (tabel 9.17). In welke mate telefonische contacten tussen huisartsen en patiënten die niet uitmondden in onderzoek, de gemiddelde duur van fase 1 hebben beïnvloed is niet bekend. Met deze restrictie mag geconcludeerd worden dat het gemiddelde tijdsverloop vanaf het ontstaan van de buikpijn tot aan het moment dat met positief resultaat om medische hulp werd verzocht, in hoofdzaak bepaald werd door uitstel van de klacht door de patiënt zelf of door zijn omgeving. De gemiddeld langste fase op één na was fase 5 (de tijd die verloopt vanaf het moment van onderzoek op de EHBO tot aan de operatie). Alleen fase 5 bij de peri-appendiculaire infiltraten duurde gemiddeld langer dan fase 1 (maar liefst 150 uur!). Het ging hier echter maar om 3 casus (figuur 9.16).

Fase 2 (de tijd die het kostte voordat een verzoek om medische hulp aan een huisarts werd gehonoreerd) en fase 3 (de duur vanaf het moment van onderzoek door de huisarts tot aan het moment waarop de patiënt zich op de EHBO meldde) waren gemiddeld verhoudingsgewijs kort. De diagnostische beslissingsprocedure, gevolgd door de huisartsen, vond plaats gedurende fase 3 terwijl de diagnostische beslissingsprocedure op de EHBO (althans voor wat betreft de geopereerde casus) plaatsvond tijdens fase 5.

Ondat het niet waarschijnlijk is dat de duur van fase 5 in hoofdzaak werd bepaald door pre-operatieve screening lijkt het zeer aannemelijk dat de gevolgde beslissingsprocedure van de huisartsen voor wat betreft de hier besproken categorieën einddiagnoses, gemiddeld minder tijd vergde dan die in het ziekenhuis; het besluit om tot operatie over te gaan liikt dus moeizamer tot stand te zijn gekomen dan de beslissing om naar het ziekenhuis te verwijzen. Gezien het verschil in consequentie tussen deze twee beslissingen ligt dit ook erg voor de hand. Fase 4, de wachttijd op de EHBO, was de kortste van alle hier besproken fasen. Fase 4 is in paragraaf 9.7.1 al ter discussie geweest. 
Vergelijking van de gemiddelde totale duur van het ziekteverloop en van de gelijknamige fasen (figuur 9.16)

Wat de totale duur van de ziekteverlopen betreft valt op dat deze voor appendiculaire infiltraten gemiddeld het langste was. Deze lange tijdsduur werd in hoofdzaak bepaald door fase 1 en fase 5 (slechts 3 casus). De redenen hiervoor zijn niet bekend. Het zal een mengeling zijn van verschillende vormen van delay: variërend van het niet als ernstig opvatten van de buikaandoening door de patiënt zelf tot het niet tevreden genoeg zijn met de diagnostische beslissing van de artsen op de EHBO.

Een erg interessante bevinding is de langere gemiddelde totale ziekteduur tot aan de operatie bij de geperforeerde appendicitiden, in vergelijking tot de ongeperforeerde. Zowel fase 1 als fase 5 waren bij de perforaties veel langer. Tussen de fasen 1 bestond een gemiddeld tijdsverschil van meer dan 10 uur, tussen de fasen 5 was dit verschil ruim 3 uur. Fase 2 was bij de perforaties gemiddeld weer veel korter ( 36 minuten, de helft). Fase 3 en 4 duurden gemiddeld ongeveer even lang zowel bij de ongeperforeerde appendicitiden als bij de geperforeerde. De bemoeienis door de huisartsen nam relatief gemiddeld weinig tijd in beslag.

Welke redenen zouden ervoor kunnen bestaan, dat een geperforeerde appendicitis gemiddeld meer tijd vergde? Een perforatie veroorzaakt toch een ernstig ziektebeeld met heftige symptomen? Het probleem is dat een appendix na ontsteking niet meteen hoeft te perforeren. Dit kan ook, bij uitblijvende adequate therapie, na verloop van langere tijd. Zolang de ontsteking nog in de appendix zit kunnen er geen complicaties optreden (Buchmann, 1984). Pas als de bacteriën de wand van de appendix penetreren of in de regionale circulatie terechtkomen bestaat er kans op perforatie. Dit kan op elk moment in het verloop van de aandoening plaatswinden. Daarom juist is vroege operatie zo gewenst omdat dan de kans om de perforatie vóór te zijn het grootst is. Over het verloop in de tijd van deze kans (lineair, exponentieel, anderszins) is in de literatuur geen informatie aangetroffen.

Er zijn verschillende oorzaken mogelijk voor de gemiddelde langere duur van het ziekteverloop van de geperforeerde appendicitiden in vergelijking tot de ongeperforeerde.

Misschien was een aantal casus niet erg imponerend. Volgens Cope (1979) verlopen acute buikbeelden minder symptoom-rijk naarmate de patiënt ouder is. Uit figuur $8.12 \mathrm{blijkt}$ dat in de Acute Buik Analyse de categorie perforaties van de appendix voor $31 \%$ uit patiënten ouder dan 60 jaar bestond tegen $15 \%$ bij de ongeperforeerde appendicitiden. In ieder geval is door het langer blootstellen van patiënten aan het ziektebeeld de kans op een perforatie groter geweest. Over de precieze oorzaken van het hier geconstateerde gemiddelde tijdsverschil is met de gegevens uit de Acute Buik Analyse niets concreets te zeggen. Het zou aanbeveling verdienen deze problematiek in een vervolgstudie meer diepgaand te bestuderen en met name een relatie te leggen tussen de factor tijd, de geslachts-leeftijdsverhouding en de symptomatologie.

Literatuur over tijdsverloop bij acute buikklachten is overigens schaars. Staniland (1980) vond dat $13 \%$ van de door hem bestudeerde patiënten met appendicitiden binnen $\mathbb{2}$ uur na het begin van de klacht werd opgenomen in het ziekenhuis. In de Acute Buik Analyse 
lag dit percentage op 30,4\%. Buchman (1984) wond bij een serie van 56 appendicitiden dat alle niet geperforeerde casus binnen 16 uur na ziekenhuisopname werden geopereerd. De casus die later geopereerd werden bleken allemaal geperforeerd te zijn (de helft wan alle perforaties). In de Acute Buik Analyse werd 95\% van alle niet geperforeerde casus en $85 \%$ van de wel geperforeerde casus binnen 16 uur na ziekenhuisopname geopereerd. Na 16 uur werden 3 geperforeerde en 3 ongeperforeerde casus geopereerd. De perforaties die na 16 uur pas werden geopereerd vormden slechts $15 \%$ (en dus niet de helft!) van het totale aantal perforaties. De bevindingen van Buchman zijn in de Acute Buik Analyse dus niet geheel bevestigd. Zoals al eerder vermell stelt Cope dat elke heftige buikpijn bij een voordien gezonde patiënt, welke langer aanhoudt dan 6 uur, een reden is tot operatieve therapie. Uit bijlage 46 blijkt dat van de categorie einddiagnoses Non Specific Abdominal pain ongeveer $63 \%$ al langer dan 8 uur buikpijn had voordat medische hulp werd ingeroepen. Er zou natuurliik over gediscussieerd kunnen worden of het hier wel casus met. heftige (een subjectief begrip overigens) buikpijn betrof, maar dit lijkt heilloos sofisme. Gesteld mag worden dat deze als aforisme gepresenteerde regel, te lezen in gangbare literatuur, in de Acute Buik Analyse niet is bevestigd.

\subsection{Conclusies en aanbevelingen betreffende doelstelling 2}

\section{Conclusies.}

- Gemeten aan de totale populatie was de gemiddelde duur van de pre-klinische fase (het tijdsverloop vanaf het begin van de buikpijn tot aan het moment van binnenkomst op de EHBO, fase 1 tot en met 3) het langste, gevolgd door de gemiddelde duur van fase 5 (het tijdsverloop vanaf het moment van onderzoek op de EHBO tot aan de operatie),

- Binnen de groep casus, die in het kader van de Acute Buik Analyse met behulp van gestructureerde verslaglegging waren verwezen (groep E), bleek fase I (tijdsverloop vanaf het begin van de buikpijn tot aan het inroepen van huisartsgeneeskundige hulp) gemiddeld verreweg de meeste tijd van de pre-klinische fase in beslag te nemen.

- De verhoudingsgewijs langere gemiddelde duur van fase 1 houdt in, dat delay in hoofdzaak werd bepaald door uitstellen van het inroepen van huisartsgeneeskundige hulp door de patiënt zelf, of door zijn omgeving.

- Zelfverwijzers meldden zich over het algemeen bij acute buikklachten sneller op de EHBO dan casus die door een huisarts werden verwezen.

- Bij geperforeerde appendicitiden bleek er een veel langere gemiddelde tijdsduur wan het ziektebeloop te bestaan tot aan het moment van opereren (tot en met fase 5) dan bij de ongeperforeerde casus. Met name fase 1 en fase 5 bepaalden deze veel langere tijdsduur.

- De in de Acute Buik Analyse zichtbaar gemaakte bemoeienis door de huisartsen nam relatief weinig tijd in beslag (fase 2 en 3 ).

\section{Aanbevelingen.}

- In verband met het belang van de factor tijd ten aanzien van de prognose bij acute buikklachten verdient het aanbeveling om naar de oorzaken van de langere gemiddelde duur van fase 1 (moment van aanvang acute buikpijn tot aan het inroepen van huisarts- 
geneeskundige hulp) nader onderzoek te doen.

- Vanwege de consequenties die het probleem heeft met betrekking tot het functioneren van zowel huisartsen als EHBO verdient het aanbeveling de factoren die leiden tot zelfverwijzing nader te onderzoeken.

- Naar de oorzaken wan het feit dat ongeperforeerde appendicitiden een korter gemiddeld tijdsverloop qua totale ziekteduur hadden dan geperforeerde, dient een nader onderzoek gedaan te worden. Dit met het oog op snellere en meer accurate diagnostiek. 


\title{
Hoofdstuk 10
}

\section{WAARSCHIJNLIJKHEIDSDIAGNOSE EN EINDDIAGNOSE}

\subsection{Inleiding}

\author{
..."Acute abdominal disease \\ Is sometimes diagnosed with ease \\ But oft the best artenups will meet \\ With sad and sorrowfull defeat"... \\ Zeta, 1955
}

In dit hoofdstuk wordt de derde doelstelling van de Acute Buik Analyse (hoofdstuk 1) behandeld. De door de huisartsen en op de EHBO gestelde waarschijnlijkheidsdiagnoses worden getoetst aan elkaar en aan de einddiagnose. In hoofdstuk 6 en hoofdstuk 8 is al uitgelegd wat de begrippen waarschijnlijkheidsdiagnose en einddiagnose inhouden. Voordat overgegaan kan worden tot realisatie van de doelstelling verdienen twee punten de aandacht.

1. Het begrip diagnose wordt niet altijd in zijn letterlijke betekenis gehanteerd (het onderkennen van de aard en de zetel van de ziekte aan zijn verschijnselen, Van Dale's Groot Woordenboek van de Nederlandse Taal): het is realiteit dat in de praktiijk een diagnose geheel of gedeeltelijk gefundeerd kan zijn op een totaal andere basis dan een puur medische (Gunn 1976). Ter verduidelijking het volgende.

Over het algemeen zou het diagnostisch proces in de Acute Buik Analyse als volgt moeten verlopen (Wulff 1980).

$\mathrm{Na}$ een patiënt met acute buikklachten onderzocht te hebben, en na het verzamelen van de gegevens en gestructureerde verslaglegging hiervan, komen huisartsen en specialisten voor een op diagnostische gronden te nemen beslissing te staan met als hoofdprobleem: bestaat er vermoeden op een ernstige intra-abdominale condlitie en zo $\mathrm{ja}$, welke. Hoe sterk is dit vermoeden, welke therapeutische consequenties zijn hieraan verbonden en wat zou er kunnen gebeuren als de diagnose onjuist blijkt te zijn. Hoe groot wordt de kans gevonden dat de diagnose wel de juiste is en welk risico kan door de onderzoekende arts worden geaccepteerd. Als uiteindelijk de kans dat de diagnose juist is groot genoeg wordt geacht, kan overgegaan worden tot de therapeutische procedure. Vaak is het stellen van een anatomisch of oorzakelijk gedefinieerde diagnose op goede gronden niet mogelijk en blijft het bij een klachtendiagnose (Non Specific Abdominal Pain en andere equivalenten). Een klachtendiagnose kan natuurlijk als zodanig ernstig imponeren dat zonder meer tot een bepaald beleid moet worden overgegaan (exploratieve laparotomie). In hoofdstuk 6 is deze problematiek al uitgebreid aan de orde geweest. Een procedure zoals hierboven geschetst, wordt natuurlijk uitsluitend in een ideale situatie gevolgd. In de praktijk van alledag spelen namelijk ook nog andere krachten, die niet in directe relatie staan tot de buikklachten, een rol. Deze krachten kunnen de diagnose en het beleid beïnvloeden of zelfs bepalen en vinden zowel bij de onderzoekende arts als bij de patiënt en zijn omgeving hun oorsprong. Zo kunnen angst om te falen en hierdoor een delay te veroorzaken, oververmoeidheid (tijdens of na een weekend-dienst), geprikkeldheid (nachtelijk uur) enzovoort een arts sneller doen besluiten tot verwijzing, opname in het ziekenhuis of zelfs 
operatie ("better to be safe than to be sorry", Cope 1979). Ook kunnen huisarts of specialist zich door (over)bezorgdheid van de patiënt of zijn omgeving gedwongen voelen de patiënl dan maar te verwijzen of op te nemen; ook sociale factoren (slechte behuizing en verzorging) en secundaire medische problematiek (slechte voedings- en hydratietoestand, diabetes mellitus) kunnen die artsen tot een dergelijke handelwijze brengen. Dit alles kan bewerkstelligen dat het beleid niet in verhouding komt te staan tot de ernst van de buikklacht en dat in bepaalde gevallen de diagnose zelfs door de arts zou kunnen worden "aangepast", geaggraveerd, om zijn beleid te rechtvaardigen.

Bijwoorbeeld: een arts is erg bang om bij een bepaalde casus de diagnose appendicitis te missen en zou graag willen verwijzen hoewel hij er, objectief gezien, geen redenen voor kan vinden . Om zijn verwijzing te legaliseren stelt hij maar de verlegenheidsdiagnose "appendicitis acuta". Of: een patiënt met buikpijn dringt erg op opname aan, om zijn beleid te rechtvaardigen stelt de arts op de EHBO maar de diagnose "mogelijke appendicitis waarvoor klinische observatie".

2. Het lijkt juist te veronderstellen dat, als iemand een bepaalde beleidslijn voorgeschreven krijgt die onder andere inhoudt dat zijn handelen controleerbaar en toetsbaar moet zijn, de kwaliteit van zijn werk hierdoor zal verbeteren. Uit $k$ linisch onderzoek is gebleken dat gestructureerde verslaglegging een verbetering van de diagnostiek bewerkstelligde van 10-15\% ten opzichte van diagnostiek zonder gestructureerde verslaglegging (Gunn 1976, De Dombal 1979;2). In de literatuur werd een dergelijk onderzoek bij huisartsen niet aangetroffen. Het is dan ook niet bekend welke invloed gestructureerde verslaglegging (hoofdstuk 7) op hun beleid zou kunnen hebben. Mogelijk dat onder huisartsen verbetering van de diagnostiek nog meer uitgesproken zou zijn dan in de kliniek, waar men toch al meer gewend is aan het werken volgens een strak patroon onder grotere controle.

Het zou zeer de aanbeveling verdienen de invloed van grotere controle en een strakker onderzoeksregime op de kwaliteiten van de huisartsgeneeskunde bij acute buikklachten in een vervolgstudie nadere aandacht te geven.

De aan de Acute Buik Analyse participerende huisartsen kregen eveneens opdracht om in alle gevallen een differentiaaldiagnose te formuleren naar aflopende graad van waarschijnlijkheid (hoofdstuk 7). Deze dwang zal in een aantal gevallen geresulteerd hebben in een vorm van verlegenheidsdiagnostiek: er moest nu eenmaal een diagnose ingevuld worden.

Tenslotte nog een kanttekening. Om ten behoeve van de vraagstelling een totaalbeeld te krijgen van de door de huisartsen gestelde waarschijnlijkheidsdiagnoses is de hiervoor benodigde informatie zowel uit groep $\mathrm{E}$ (door een huisarts verwezen, met gestructureerde verslaglegging) als uit groep $D$ (door een huisarts werwezen, zonder gestructureerde verslaglegging) verkregen. Bij de casus uit de laatste groep is de verwijsdiagnose achterhaald door telefonisch informeren (hoofdstuk 7). Hierdoor was flatteren van deze diagnoses natuurlijk niet uitgesloten, immers: de mogelijkheid was aanwezig dat een aantal huisartsen gedurende de tijd die verliep tussen de verwijzing naar het ziekenhuis en het moment van telefonische informatie naar de verwijsdiagnose, informatie vanuit het ziekenhuis over de verwezen casus had gekregen, maar dit desgevraagd ontkende.

Hoe groot de invloed van alle hiervoor genoemde factoren op de uitkomsten van de Acute Buik Analyse is geweest kan niett worden gezegd. 
Analyseren van de gestelde diagnoses wordt hierdoor natuurlijk niet minder interessant. Omdat een aantal categorieën einddiagnoses slechts uit een gering aantal casus bestaat (tabel 8.7, bijlage 9), vaak verre van volledig is (gynaecologie, paragraaf 7.3) of een verzameling vormt (categorie "overige diagnoses", bijlage 13), blijven deze categorieën als afzonderlijke groepen zoveel mogelijk buiten beschouwing. De aandacht wordt vooral gericht op de numeriek sterkste groepen: Non Specific Abdominal Pain en appendicitis.

\subsection{Waarschijnlijkheidsdiagnose versus einddiagnose}

In deze paragraaf worden de door de huisartsen en de op de EHBO gestelde waarschijnlijkheidsdiagnoses uitgezet en vergeleken met de einddiagnoses. Om de door de huisartsen gestelde waarschijnlijkheidsdiagnoses te kunnen vergelijken met die welke op de EHBO waren gesteld, is gebruik gemaakt van groep $\mathrm{D}$ en $\mathbb{E}$ (door aan de Acute Buik Analyse participerende huisartsen verwezen). De resultaten van deze vergelijking zijn weergegeven in tabel 10.1 .

Tabel 10.1

Waarschijnlijkheidsdiagnoses huisartsen en EHBO versus einddiagnose. Groep D en E.

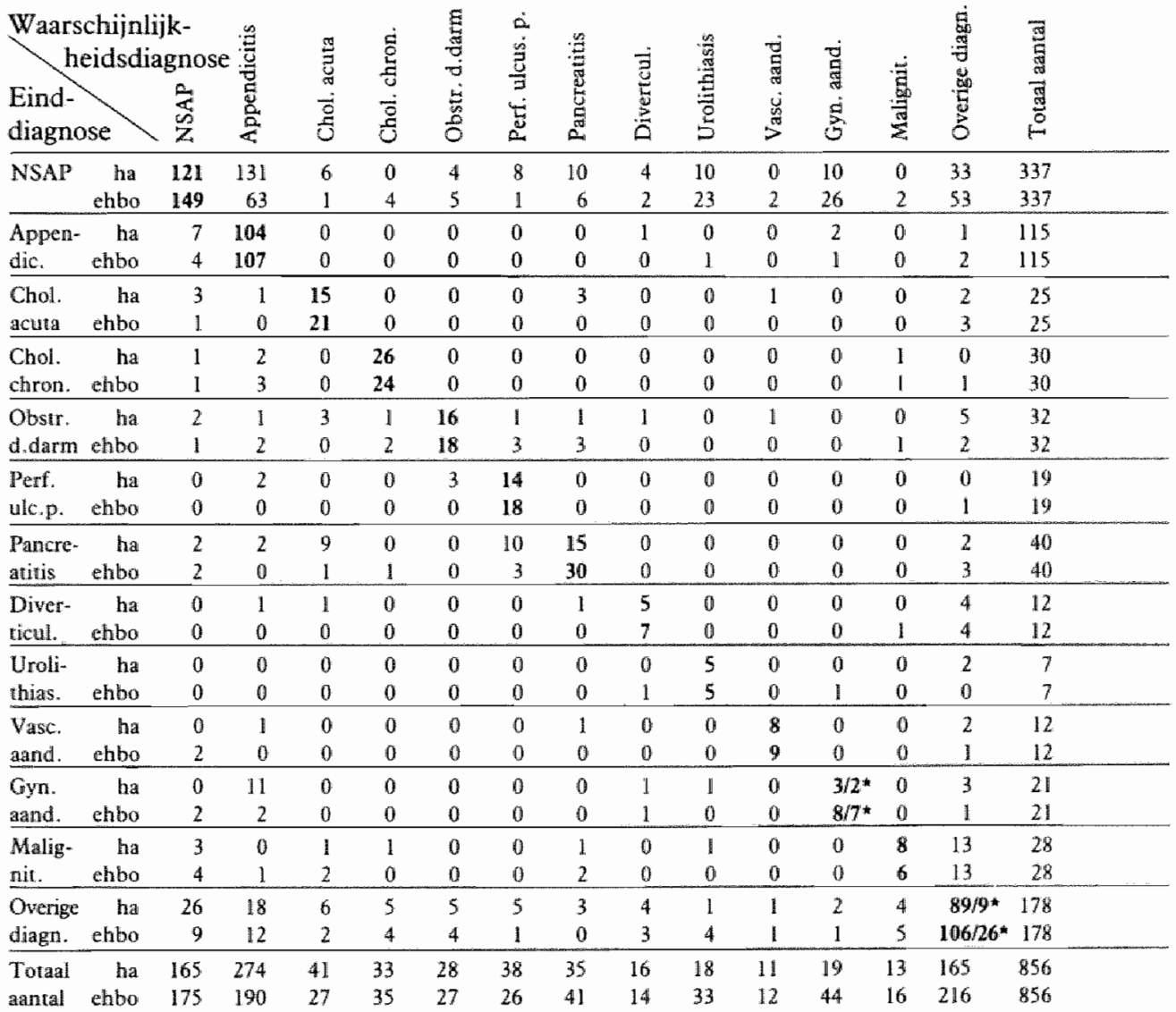

- Onjuiste werkelijke diagnose: bij de categorie gynaecologische afwikingen in tubel 10.1 bijvoorbedd beteken $7^{*}$ dat bij 7 casus op de EHBO wel to een gynaecologische afwijking werd besloten, maar miet tot de juiste: zo werd in een geval the warschijnilikheidsdiagnose adnexits gesteld terwijl het in werkelijkheid on een 
Het meest opvallende aan tabel 10.1 is het grote aantal diagnoses appendicitis dat gesteld werd (meer door huisartsen dan op de EHBO) terwijl bij deze casus uiteindelijk geen objectieve verklaring voor de klachten bestond en besloten moest worden tot de einddiagnose Non Specific Abdominal Pain.

Bijlage 49 maakt (vanwege de eerder genoemde mogelijkheid tot flatteren van de diagnose door de huisartsen) vergelijking van de uitkomsten van groep $D$ en $E$ met die van alleen groep E mogelijk.

Tabel 10.2 toont de frequentieverdeling van de op de EHBO gestelde waarschijnlijkheidsdiagnoses en de toetsing van deze diagnoses aan de einddiagnose. Om dezelfde reden als bij tabel 10.1 valt ook hier de diagnose appendicitis op.

Tabel 10.2

Waarschijnlijkheidsdiagnose EHBO versus einddiagnose.

Totale populatie.

Waarschijnlijk-

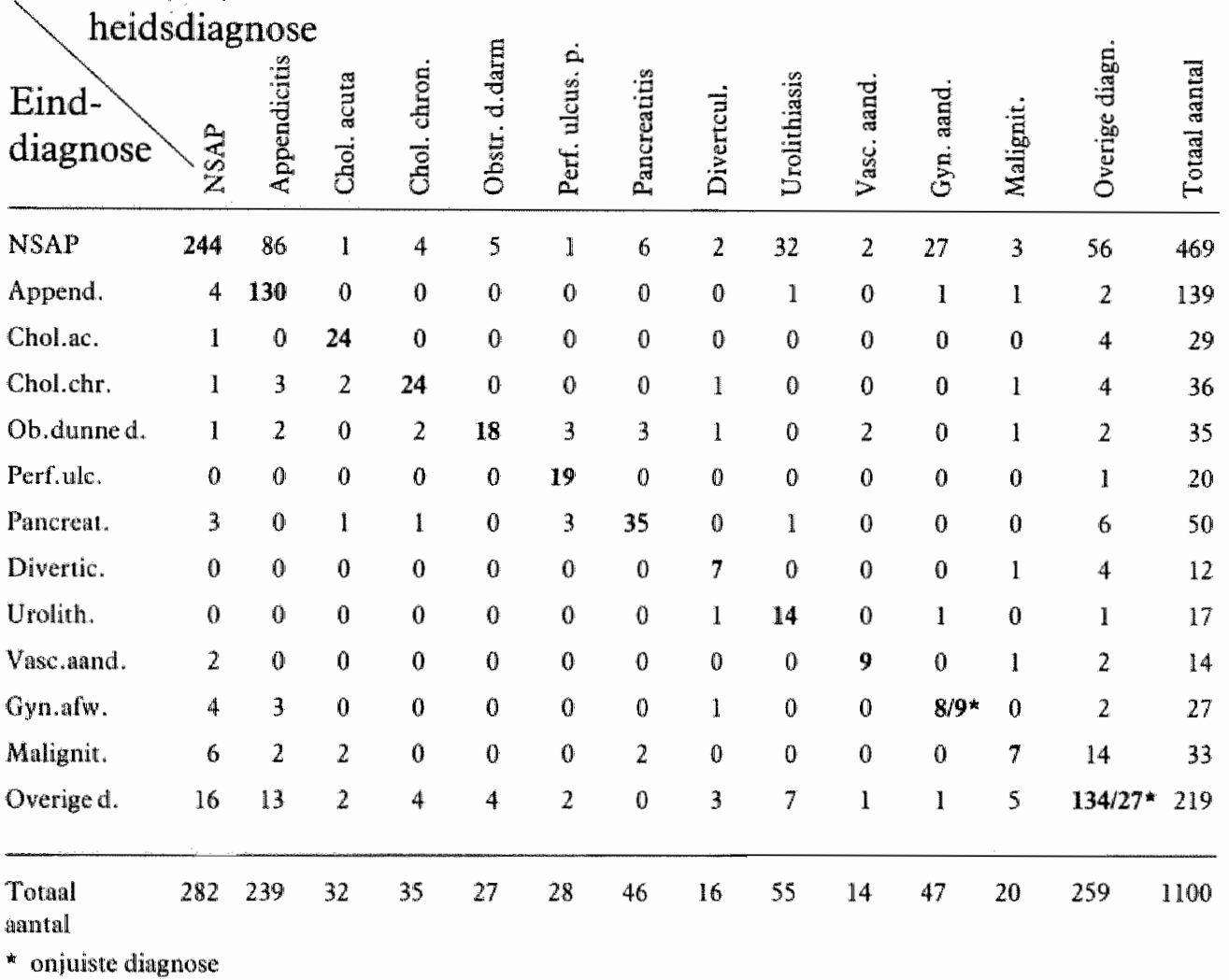

Figuur 10.3 toont de percentages waarin de door de huisartsen en op de EHBO gestelde waarschijnlijkheidsdiagnoses correspondeerden met de einddiagnoses. Tevens zijn in deze figuur duidelijk de verschillen in percentagehoogte te zien tussen huisartsen en EHBO. 


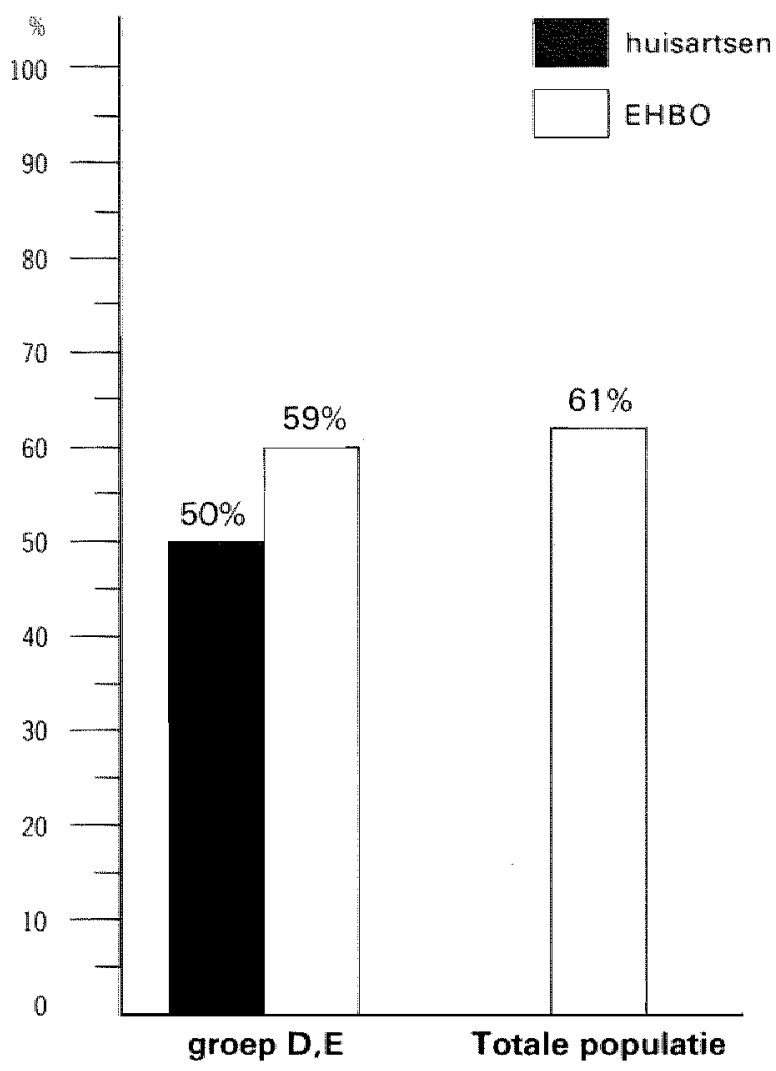

Figuur 10.3.

Percentage waarschijnlijkheidsdiagnose $=$ eindiagnose, woor huisartsen en op de EHBO.

Groep D \& E $(\mathrm{n}=856)$.

Totale populatie $(\mathrm{n}=1100)$.

Bij bestudering van tabel 10.1 valt meteen op dat een niet gering aantall causaal en anatomisch gedefinieërde waarschijnlijkheidsdiagnoses, met name die welke door de huisartsen waren gesteld, uiteindelijk onder de einddiagnose Non Specific Abdominal Pain moesten worden gerangschikt. Vooral de door de huisartsen gestelde diagnose appendicitis kon in $62 \%$ van de gevallen niet worden bevestigd ( $48 \%$ bleek a-specifiek). Ook werden de waarschijnlijkheidsdiagnoses cholecystitis acuta en perforatie van een ulcus pepticum waak gesteld in gevallen, waarbij tenslotte besloten werd tot einddiagnose pancreatitis. 
Tabel 10.4 geeft de situatie voor bovengenoemde groepen en categorieën weer:

Tabel 10.4

Waarschijnlijkheidsdiagnoses waarbij later in een hoog percentage de einddiagnose Non Specific Abdominal Pain of pancreatitis gesteld moest worden. Groep D en $\mathrm{E}(\mathrm{n}=856)$.

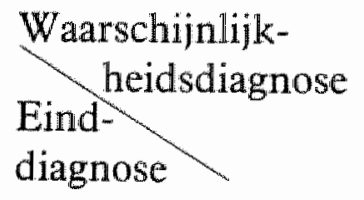

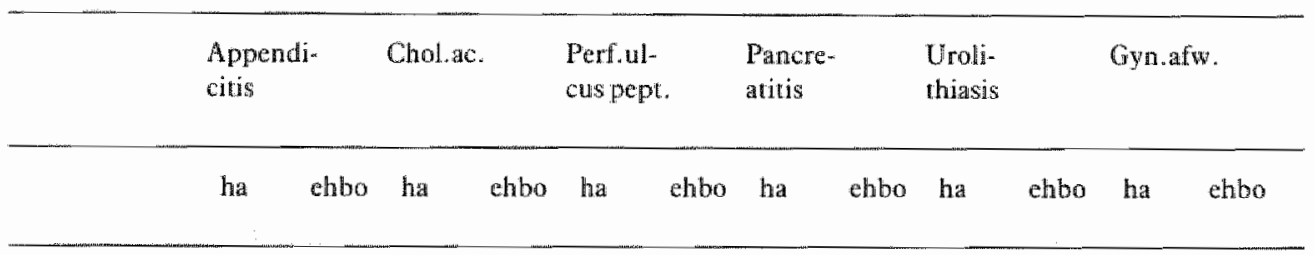

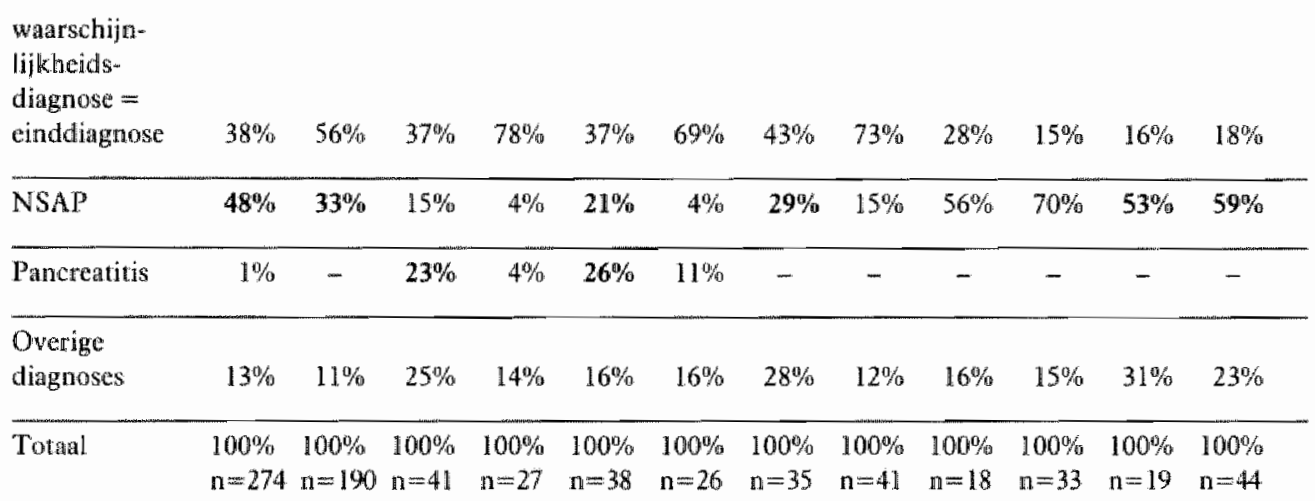

Uit tabel 10.4 blijkt dat het voor zowel huisartsen als op de EHBO vaak moeite kostte om te differentiëren tussen een aantal diagnoses. Met name bij de waarschijnlijkheidsdiagnose appendicitis bleek dat een flink percentage hiervan uiteindelijk onder de categorie einddiagnose Non Specific Abdominal Pain gerangschikt moest worden. Er zijn verschillende verklaringen mogelijk voor dit fenomeen. Angst om te falen of om tijd te verliezen is zo'n verklaring. Er wordt dan op safe gespeeld (minimax-loss-principle, hoofdstuk 6). Ook druk door de patiënt of door zijn omgeving op de arts uitgeoefend om verwezen te worden kan een rol spelen (paragraaf 10.1). Tenslotte zou het mogelijk kunnen zijn dat een deel van de als appendicitis beschouwde casus dit inderdaad ook was: self-limiting appendicitis. Puylaert et al.(1987) hebben het vóórkomen van self-limiting appendicitis aannemelijk gemaakt. Uit hun onderzoek bleek onder meer, dat bij een aantal patiënten, waarbij met behulp van gedoseerde compressie-echografie de diagnose appendicitis werd gesteld, de klachten spontaan afnamen of zelfs geheel verdwenen. Dezelfde theorieën zijn uiteraard van toepassing op de andere waarschijnlijkheidsdiagnoses, welke later Non Specific Abdominal Pain bleken te zijn. Saegesser (1981) wijst al in de richting van self-limiting 
Casus als hij veronderstelt dat indigestie na een copieuze maaltijd in feite een passagère pancreatitis is. Wat uit tabel 10.4 eveneens blijkt is dat, in tegenstelling tot de op de EHBO gestelde diagnoses, de door de huisartsen gestelde diagnoses cholecystitis acuta en perforatie van een ulcus pepticum voor respectievelijk $23 \%$ en $26 \%$ een pancreatitis bleken te zijn (EHBO 4\% en 11\%). De grotere mogelijkheden tot aanvullend onderzoek die de EHBO ter beschikking stonden zullen in belangrijke mate bepalend zijn geweest voor deze verschillen. Hoe dan ook: het bleek voor de huisartsen veel moeilijker te zijn om te differentiëren tussen de diagnose cholecystitis acuta en perforatie van een ulcus pepticum enerzijds, en de diagnose pancreatitis anderzijds.

Bij beschouwing van figuur 10.3 (groep D en E) blijkt dat het percentage waarschijnlijkheidsdiagnose = einddliagnose voor wat betreft de $\mathrm{EHBO} 9 \%(59 \%-50 \%)$ hoger was dan dat van de huisartsen. Uitsluitend gemeten in groep $\mathrm{E}$ was dit verschil groter: $17 \%(63 \%$ $46 \%$ ), zie billage 49 . De verschillen tussen huisartsgeneeskunde en klinische geneeskunde in aanmerking nemende (hoofdstuk 1) en tevens overwegende dat de EHBO na verwijzing door de huisarts op de hoogte werd gesteld van diens diagnose (hoofdstuk 7) mogen de hier gevonden verschillen niet groot worden genoemd. Uit figuur 10.3 blijkt eveneens dat het percentage juiste diagnoses voor de gehele onderzoekspopulatie $(n=1100)$ gesteld op de $\mathrm{EHBO} 61 \%$ was.

De waarde van al deze uitkomsten is betrekkelijk. Hoewel de percentages dit wel suggereren, mag zeker niet de conclusie getrokken worden dat de huisarts of de EHBO het in zoveel gevallen zonder meer fout deed. Ondanks het feit dat achteraf een andere diagnose moest worden gesteld, is een op goede gronden gestelde klachtendiagnose zeer verdedigbaar. Daarnaast kan een ziektebeeld in de tijd snel van aard veranderen (Cope 1979). Toch kunnen de in figuur 10.3 gevonden percentages niet hoog worden genoemd tegen de achtergrond van wat De Dombal stelt: bij acute buikklachten kan middels anamnese, lichamelijk onderzoek en simpel aanvullend onderzoek de diagnose met een zekerheid van $80-90 \%$ worden gesteld.

\subsection{Conclusies en aanbevelingen betreffende doelstelling 3 .}

\section{Conclusies.}

- Veel waarschijnlijkheidsdiagnoses (anatomisch of causaal gedefinieërd) met name appendicitis, bleken achteraf onder de einddiagnose Non Specific Abdominal Pain te moeten worden gerangschikt. Vooral bij de diagnoses gesteld door huisartsen was dit het geval.

- De waarschijnlijkheidsdiagnoses cholecystitis acuta en perforatie van een peptisch ulcus werden in een aanzienlijk aantal gevallen gesteld bij gevallen, die later de einddiagnose pancreatitis kregen. Ook dit was vooral bij de huisartsen het geval.

- Het percentage "juiste diagnose" was bij de waarschijnlijkkeidsdiagnoses die gesteld werden door de huisartsen $9 \%$ lager dan bij die welke gesteld waren op de EHBO (respectievelijk $50 \%$ en $59 \%$ ).

- Het percentages "juiste diagnoses" voor de gehele onderzoekspopulatie $(\mathbf{n}=1100)$ gesteld op de EHBO was $61 \%$. 


\section{Aanbevelingen.}

- Onderzoek naar besliskundige implicaties van symptomen en bevindingen dient met name bij die casus, waarbij de diagnose Non Specific Abdominal Pain, appendicitis, cholecystitis acuta, perforatie van een ulcus pepticum en pancreatitis werd gesteld, op grond van de in de Acute Buik Analyse gesignaleerde frequent voorkomende onderlinge verwisselingen yan deze diagnoses, bevorderd te worden.

- De in de Acute Buik Analyse gevonden percentages "juiste diagnoses" wettigen inspanningen om tot verbetering te komen, bijwoorbeeld door de ontwikkeling van protocollen en algoritmen ten behoeve van de diagnostiek van acute buikaandoeningen. 


\section{Hoofdstuk 11}

\section{ALGEMENE CONCLUSIES EN AANBEVELINGEN}

De studie was gericht op patienten met acute buikpijn die hiervoor op de EHBO van het Academisch Ziekenhuis Maastricht werden onderzocht. In totaal zijn er 1100 casus bestudeerd. Het doel van de studie, welke Acute Buik Analyse werd genoemd, was om meer inzicht te krijgen in wat er met een patiënt met acute buikpijn gebeurt vanaf het moment van ontstaan van de pijn tot aan de oplossing van het diagnostische probleem. Om dit doel te kunnen bereiken werden de patientenpopulatie en het verloop van de verschillende ziektebeelden geanalyseerd, werd vastgesteld wat de duur van de verschillende fasen in het ziekeverloop was en werden tenslotte de zowel door de huisartsen als op de EHBO gestelde waarschijnlijkheidsdiagnoses getoetst aan elkaar en aan de einddiagnose.

Op grond van resultaten van de analyse van de patiëntenpopulatie en het verloop van de casus kan het volgende worden geconcludeerd.

- Tijdens waarneming door een andere huisarts werd inroepen van huisartsgeneeskundige hulp uitgesteld.

- Het percentage spoedgevallen $(42,2 \%)$ was lager dan mocht worden verondersteld.

- Er zijn te weinig patiënten onmiddellijk na eerste onderzoek op de EHBO terugverwezen naar de huisarts.

- Bij opname in het ziekenhuis bleek in bijna alle gevallen vooraf op de EHBO een anatomisch of causaal gedefinieerde waarschijnlijkheidsdiagnose te zijn gesteld: van alle opnames bleek ruim eenvijfde tenslotte Non Specific Abdominal Pain te zijin.

- In vergelijking tot internationale cijfers zijn de in de Acute Buik Analyse gevonden percentages negatieve laparotomieën $(7,3 \%)$ en appendices sanae $(14,5 \%)$ laag (internationaal respectievelijk $20-80 \%$ en $25 \%$ ).

- De kans op ernstige buikpathologie bij acute buikpijn nam toe met de leeftijd; de kans op appendicitis daalde.

- Zoals bij andere series nam de categorie einddiagnose Non Specific Abdominal Pain numeriek de eerste plaats in.

- Bij de patiënten die zich op eigen initiatief met buikklachten op de EHBO meldden bleek bijna twee maal zoveel Non Specific Abdominal Pain als einddiagnose voor te komen als bij de patiënten die door een huisarts naar het ziekenhuis waren verwezen.

\section{Resultaten van de tijdsanalyse van de verschillende fasen in het ziekteverloop.}

- Binnen de totale populatie was de gemiddelde duur van de pre-klinische fase (fase 1 tot en met 3) het langste, gevolgd door fase 5 (hett tijdsverloop vanaf het moment van onderzoek op de EHBO tot aan de operatie).

- Bij de casus die door de huisartsen met behulp van gestructureerde verslaglegging naar de EHBO werden verwezen bleek fase 1 (het tijdsverloop vanaf het begin van de buikklachten tot aan het inroepen van huisartsgeneeskundige hulp) gemiddeld verreweg de meeste tijd van de pre-klinische fase in beslag te nemen.

- Uitstellen van het inroepen van huisartsgeneeskunduge thulp door de patiẻnt zelf en/of 
zijn omgeving vormde de hoofdoorzaak van die relatief langere gemiddelde duur van de pre-klinische fase.

- Zelfverwijzers meldden zich bij acute buikklachten sneller op de EHBO dan patiënten die door een huisarts werden verwezen.

- Bii geperforeerde appendicitiden bleek er gemiddeld een veel langere tijdsduur te bestaan vanaf het moment van ontstaan van de pijn tot aan de operatie, dan bij de ongeperforeerde casus.

- De in de Acute Buik Analyse zichtbaar gemaakte bemoeienis door de huisartsen nam relatief erg weinig tijd in beslag.

\section{Resultaten van de analyse van de diverse gestelde diagnoses.}

- Veel waarschijnlijkheidsdiagnoses (met name appendicitis) bleken achteraf onder de einddiagnose Non Specific A bdominal Pain te moeten worden gerangschikt. Vooral bij de door de huisartsen gestelde diagnoses was dit het geval.

- De waarschijnlijkheidsdiagnoses cholecystitis acuta en perforatie van een ulcus pepticum werden in een aanzienlijk aantal gevallen gesteld bij casus die later de einddiagnose pancreatitis kregen. Dit vond vooral plaars bij de door de huisartsen gestelde diagnoses.

- Het percentage "juiste diagnoses" lag bij de waarschijnlijkheidsdiagnoses, gesteld door de huisartsen $9 \%$ lager dan bij die welke gesteld werden op de EHBO.

- Het percentage "juiste diagnoses" voor de gehele onderzoekspopulatie $(\mathrm{n}=\mathbb{1 1 0 0})$ gesteld op de EHBO was $61 \%$.

\section{Aanbevelingen.}

1. In verband met het belang van de factor tijd bij de prognose van acute buikaandoeningen dient onderzocht te worden welke factoren in welke mate bepalend zijn voor uitstel van het inroepen van (huisarts)geneeskundige hulp.

2. Het getuigt van wijs beleid het fenomeen "zelfverwijzing" te ontmoedigen. Vanwege de consequenties die het heeft met betrekking tot het functioneren van zowel huisartsen als $\mathbb{E} H B O$ dient het mechanisme wat leidt tot zelfverwijzing nader onderzocht te worden.

3. Omdat ruim eenvijfde van het aantal opnames achteraf Non Specific Abdominal Pain bleek te zijn dient, ten behoeve van vroege herkenning van deze "aandoening", onderzoek te worden gedaan naar het klinische beeld hierwan.

4. Naar de oorzaken van de langere gemiddelde totale ziekteduur van de geperforeerde appendicitiden in vergelijking tot de ongeperforeerde, zou nader onderzoek moeten worden gedaan met het oogmerk perforatie te kunnen vermijden.

5. Onderzoek naar de besliskundige implicaties van symptomen en bevindingen dient met name bij die casus waarbij de diagnoses Non Specific Abdominal Pain, appendicitis, cholecystitis acuta, perforatie van een ulcus pepticum en pancreatitis werden gesteld, op grond van de in de Acute Buik Analyse gesignaleerde frequent voorkomende onderlinge verwisselingen, bevorderd te worden.

6. De in de Acute Buik Analyse gevonden percentages "juiste diagnose" wettigen inspanningen om tot verbetering te komen, bijvoorbeeld door de ontwikkeling van protocollen en algoritmen ten behoeve van de diagnostiek van acute buikaandoeningen. 


\section{SAMENVATTING}

Er bestaat een schaarste aan relevante literatuur over de diagnostiek en het beleid bij acute buikpijn. Over de rol van de huisartsgeneeskunde ontbreekt in dit verband vrijwel ledere informatie. De hier beschreven studie, Acute Buik Analyse genaamd, heeft dan ook als doel om meer inzicht te geven in de gebeurtenissen rond een patiënt met acute buikpijn. Hiertoe zijn drie doelstellingen geformuleerd.

1. Analyse van de patiëntenpopulatie en het verloop van de casus tot aan de einddiagnose.

2. Tijdsanalyse van de verschillende fasen in het ziekteverloop tot aan ontslag of overlijden.

3. Analyse van de door de huisartsen en op de EHBO van het Academisch Ziekenhuis Maastricht gestelde waarschijnlijkheidsdiagnoses, getoetst aan elkaar en aan de einddiagnoses.

Acute buikpijn kan vele tientallen oorzaken hebben, variërend van onschuldig tot levensbedreigend. Onbehandeld kan de dood het gevolg zijn, terwijl een juist en zo vroeg mogelijk gestart beleid meestal volledige genezing bewerkstelligt.

Verkeerde diagnose en beleid zijn in hoofdzaak gevolg van een, tijdens de medische opleiding geleerde, verkeerde interpretatie van bevindingen. In verschillende centra wisselde het percentage negatieve laparotomieën van 20 tot $80 \%$ terwijl soms de sterfte bij appendectomieën drie maal zo hoog was als het Europese gemiddelde van 0,1\%.

De term "acute buik" wordt veel gebruikt. Benadrukt dient evenwel te worden dat het slechts een uitdrukking van ernst is, en geen diagnose. Omdat het een té beladen begrip is (het suggereert de noodzaak tot operatie terwijl in de praktijk de meeste, als "acute buik" gepresenteerde gevallen helemaal niet worden geopereerd) lijkt het beter om in plaats van "acute buik" te spreken van "acute buikpijn".

Sinds mensenheugenis is er gezocht naar de oplossing van het probleem acute buikpijn. Reeds in de Oudheid zijn de symptomen al zeer nauwkeurig beschreven. Tot aan de veertiende eeuw (begin van de Renaissance) is om religieuze redenen anatomisch onderzoek nauwelijks mogelijk. Het toestaan ervan is de eerste grote sprong voorwaarts geweest. Door de ontwikkeling van de antisepsis en vervolgens asepsis, anaesthesie en bestrijding van infecties gedurende het eunde van de vorige, begin deze eeuw, heeft de diagnostiek en therapie bij acute buikpijn pas zijn moderne vorm gekregen. Deze, nog grotere, tweede sprong voorwaarts werd nog geen honderd jaar geleden ingezer!

Zonder voldoende kennis van de anatomie en de fysiologie kan er van adequaat medisch handelen bij acute buikpijn geen sprake zijn. Vooral de fysiologie van de buikpijn is belangrijk. Er kunnen drie soorten buikpijn onderscheiden worden: pariëtale, viscerale en gerefereerde. Dit onderscheid is ten behoeve van de diagnostiek bruikbaar.

Door het vaststellen en ordenen van symptomen en bevindingen wordt het mogelijk een diagnostische beslissing te nemen. Waarschijnlijk gebruikt elke arts in verschillende gevallen verschillende methodes om tot een diagnose te komen. De kunst is echter om een gulden middenweg te vinden tussen een waarschijnlijkheidsstrategie en het "minimaxloss-principle", het zo minimaal mogelijk proberen te houden van het maximaal te verwachten verlies. De diagnostiek door de huisarts en de specialist verschillen van dimensie 
omdat hun werkterreinen in een ander deel van het klinische spectrum liggen. De huisarts ziet een meer diffuse groep van patiënten dan de specialist.

Om op de doelstellingen in te kunnen gaan is een prospectief onderzoek gedaan gedurende negentien maanden, van 1-11-1982 tot 31-5-1984. Er werden 1100 casus bestudeerd, waarvan de gegevens op speciale formulieren werden vastgelegd. Het Academisch Ziekenhuis Maastricht en 72 huisartsen werkten aan de Acute Buik Analyse mee.

Van de totale patiëntenpopulatie werd het merendeel naar de EHBO verwezen door een huisarts (909 casus). Een aantal casus (160) is op eigen initiatief naar de EHBO gegaan wegens buikklachten. Van alle casus (1100) werd ongeveer drievierde door de chirurg behandeld. Tweederde werd opgenomen in het ziekenhuis. Er werden 396 operaties uitgevoerd.

De overall-mortaliteit was gelijk aan het nationale gemiddelde $(5,4 \%)$. De percentages negatieve laparotomieën $(7,3 \%)$ en appendix sana $(14,5 \%)$ waren laag. De meest voorkomende einddiagnose was Non Specific Abdominal pain $(42,6 \%)$.

Van waarde voor de diagnostiek is de leeftijd: jongeren van 10-30 jaar hadden een veel grotere kans op Non Specific Abdominal Pain en appendicitis dan ouderen, waarvoor de kans op appendicitis weliswaar daalde, maar waarvoor in het algemeen de kans op ernstige buikpathologie sterk toenam (cholecystitis, vasculaire aandoeningen, maligniteit). $\mathrm{Bij}$ de patiënten die op eigen initiatief naar de $\mathrm{EHBO}$ gingen bleek procentueel twee maal zoveel Non Specific Abdominal Pain voor te komen als bij de rest van de onderzoekspopulatie.

Hoewel de huisarts slechts eenderde van alle tijd voor zijn patiënten beschikbaar is, werd drievierde van de verwijzingen door de eigen huisarts gedaan. Hieruit bleek dat patiënten met buikklachten het inroepen van medische hulp in een aantal gevallen uitstelden. Van alle verwijzingen door een huisarts gebeurde $43 \%$ tijdens een praktijkconsult en $57 \%$ na huisbezoek. Het percentage spoedgevallen bedroeg $42,2 \%$, gelijkelijk verdeeld over consulten en visites.

De factor tijd, bepalend element van de prognose, is gemeten bij alle 1100 casus. De gemiddelde duur van de pre-klinische fase was 42 uur en 26 minuten. In duur werd zii gevolgd door de wachttijd op de operatie, gemiddeld 31 uur en 42 minuten. De bemoeienis van de huisarts nam gemiddeld relatief weinig tijd in beslag: 1 uur.

Bij geperforeerde appendicitiden was de gemiddelde duur van het ziekteverloop opvaliend veel langer dan bij niet geperforeerde appendicitiden. Met name de pre-klinische fase en de wachttijd tot de operatie waren bepalend voor deze langere duur. Een sluitende verklaring hiervoor is niet voorhanden. Mogelijk een mengeling van delay en minder overtuigende symptomatologie.

Tijdens het analyseren van de gestelde diagnoses viel op dat het, vooral wat betreft de huisartsen, nogal eens voorkwam dat de gestelde waarschijnlijkheidsdiagnoses tenslotte a-specifiek bleken te zijn. De door de huisartsen bij verwijzing gestelde diagnose appendicitis bleek niet alleen in $62 \%$ van de gevallen niet te kunnen worden bevestigd, maar bleek ook in $48 \%$ (!) uiteindelijk a-specifiek te zijn. Verschillende verklaringen voor dit fenomeen zijn mogelijk zoals: 
1. "opwaartse druk" door de patiënt om verwezen c.q. opgenomen te worden;

2. de bij de arts bestaande vrees om te falen of een delay te veroorzaken;

3. de mogelijkheid dat het toch een (self-limiting) appendicitis is geweest.

Verder bleek het voor huisartsen moeilijk, te differentiëren tussen de diagnose cholecystitis acuta en perforatie van een ulcus pepticum enerzijds en de diagnose pancreatitis anderzijds. De specialist had hier minder moeite mee. De grotere mogelijkheid en noodzaak tot aanvullend onderzoek in het ziekenhuis is zeker van invloed geweest op deze uitkomst.

Tenslotte werd er een verschil gevonden van $9 \%$ ten gunste van de EHBO bij vergelijking van het percentage juiste diagnoses gesteld door de huisartsen met die welke op de EHBO werden gesteld. Overall bleek het percentage juiste diagnoses voor wat betreft de huisartsen ( 856 casus) $50 \%$ en voor wat betreft de $\mathrm{EHBO}$ (bij alle 1100 gevallen) $61 \%$ te zijn.

De belangrijkste conclusies die uit de Acute Buik Analyse getrokken kunnen worden zijn:

- tijdens waarneming werd het inroepen van huisartsgeneeskundige hulp uitgesteld;

- er kunnen méér patiënten onmiddellijk na eerste onderzoek op de EHBO terugverwezen worden naar de huisarts;

- bij meer dan eenvijfde van alle opnames in het ziekenhuis bleek achteraf geen objectiveerbare oorzaak voor de buikklachten aanwijsbaar;

- de gevonden percentages negatieve laparotomieën en appendix sana zijn als laag te beschouwen;

- de kans op ernstige buikpathologie nam toe met de leeftijd, de kans op appendicitis daalde daarentegen;

- de categorie einddiagnose Non Specific Abdominal Pain nam numeriek de eerste plaats in $(42,6 \%$ van de totale onderzoekspopalatie);

- bij de zelfverwijzers bleek procentueel bijna twee maal zoveel Non Specific Abdominal Pain als einddiagnose voor te komen dan bij de patiënten die door de huisarts naar de EHBO waren verwezen;

- gemeten aan de totale populatie was de gemiddelde duur van de fase vanaf het begin van de buikklacht tot aan het moment van binnenkomst op de EHBO het langste, gevolgd door de fase gerekend vanaf het moment van onderzoek op de EHBO tot aan de operatie;

- in de fase tot aan binnenkomst op de EHBO bleek de gemiddelde duur wan de tijd vanaf het begin van de klacht tot aan het inroepen van huisartsgeneeskundige hulp het langste te zijn; deze tijdsduur werd hoofdzakelijk bepaald door de patiënt zelf en/of diens ongeving;

- zelfverwijzers meldden zich met acute buikklachten sneller op de EHBO dan patiënten die door een huisarts verwezen werden;

- bij geperforeerde appendicitiden bleek er een veel langere gemiddelde tijdsduur te bestaan tot aan het moment van opereren in vergelijking tot de ongeperforeerde casus;

- de in de Acute Buik Analyse zichtbaar gemaakte bemoeienis door de huisartsen besloeg in thet totale ziektebeloop gemiddeld niet meer dan enkele procenten van de rotale gemiddelde tijdsduur;

- het verschil in percentages juiste diagnoses tussen huisartsen en EHBO was 9\%;

- vooral bij de waarschijnlijkheidsdiagnoses gesteld door de huisartsen kwam het voor 
dat met name de diagnose appendicitis achteraf niet bevestigd kon worden en bij de Non Specific Abdominal Pain moest worden gerekend;

- met name de door de huisartsen gestelde waarschijnlijkheidsdiagnoses cholecystitis acuta en perforatie van een ulcus pepticum bleken achteraf vaak pancreatitis te zijn.

De belangriikste aanbevelingen zijn:

- in verband met het belang van de factor tijd bij de prognose van acute buikaandoeningen dient onderzocht te worden welke factoren in welke mate bepalend zijn voor uitstel van inroepen van (huisarts) geneeskundige hulp;

- her geruigt wan wijs beleid het fenomeen "zelfverwijzing" te ontmoedigen; vanwege de consequenties die het heeft met betrekking tot het functioneren van zowel huisartsen als EHBO verdient het eveneens aanbeveling de zelfverwijzing nader te bestuderen;

- het verdient aanbeveling nader onderzoek te doen naar de redenen waarom de gemiddelde duur van het ziekteverloop bij geperforeerde appendicitiden langer is dan bij de niet geperforeerde;

- onderzoek naar besliskundige implicaties van de symptomatologie van met name: Non Specific Abdominal Pain, appendicitis acuta, cholecystitis acuta, perforatie van een ulcus pepticum en pancreatitis dient bevorderd te worden; dit in verband met de frequent voorkomende onderlinge verwisseling van deze diagnoses;

- de hoogte van het percentage "juiste diagnoses" wettigen inspanningen om tot verbetering te komen, bijvoorbeeld door de ontwikkeling van protocollen en algoritmen ten behoeve van de diagnostiek van acute buikaandoeningen. 


\section{SUMMARY}

There is a relative shortage of relevant literature concerning diagnostics and management of acute abdominal pain. As far as the part of the practical medicine is concerned, practically every information is lacking. "The aim the thesis, called Acute Abdomen Analysis, is to give a better understanding in the events of a patient with acute abdominal pain. For this purpose, three problems are formulated.

1. Analysis of the patient population and the course of the cases up to the final diagnoses.

2. Analysis of the time of the various stages in the progress of the disease up to dismissal from the hospital or death.

3. Analysis of the preliminary diagnoses, made by the G.P.'s and the Accident \& Emergency Dept. of the University Hospital of Maastricht, tested mutually and to the final diagnoses.

Acute abdominal pain can be caused by dozens of reasons, varying from innocent up to life threatening. Not treated, death can be the consequence, whereas accurate and quickly started management mostly effects full recovery.

Wrong diagnosis and management are mainly the consequence of an inaccurate interpretation of conclusions, learned during the medical training. In several centres the percentage of negative laparotomies fluctuated from $20-80 \%$, whereas the mortality of appendectomies was three times as high as the European average of $0.1 \%$.

The phrase "acute abdomen" is frequently used. However, it has to be emplasized that it is only an expression of gravity and not a diagnosis. As the phrase is charged too much (though it suggests the opposite, most of the as "acute abdomen" presented cases are not operated at all), it appears preferable to speak about "acute abdominal pain" instead of "acute abdomen".

Since time immemorial man has been searched for the solution of the problem "acute abdominal pain". Already in ancient times, the symptoms are described exactly. For religious reasons up to the 14 th century (Renaissance) anatomic examination was hardly possible. The permission granted was the first important forward movement. Through the development of antisepsis and subsequently asepsis, anaesthesia and suppression of infections during the end of the last and the early part of this century, diagnostics and therapy of acute abdominal pain began to take its modern shape. This second forward leap, still more considerable, only started less than 100 years ago!

Without sufficient knowledge of anatomy and physiology, adequate medical treatment on acute abdominal pain is out of question. Especially the physiology of abdominal pain is important. Three kinds of abdominal pain can be distinguished: parietal, visceral and referred pain. This difference is useful for the benefit of diagnostics.

By establishing and sorting out symptoms and conclusions, it becomes possible to make a diagnostic decision. Probably every physician uses different methods in different cases to make a diagnosis. The crucial point is to find the golden medium between probability strategy and the "minimax-loss-principle", trying to maintain the maximall possible loss as 
minimal as possible. The diagnostics by G.P. and specialist are of different dimensions, because the spheres of activity are separated in another part of the clinical spectrum. The G.P. examines a more diffuse group as the specialist does.

To be in a position to answer the question, a prospective investigation has been executed during 19 months. From November 1st. 1982 to May 31st. 1984, 1100 cases were studied and recorded on special forms. The University Hospital of Maastricht and 72 G.P.'s participated in this Acute Abdomen Analysis.

From the full patient population the greater part was referred to the Accident \& Emergency Dept. by the G.P. (909 cases). A number (160) checked in on their own initiative with acute abdominal pain at the Accident \& Emergency Dept. Of all cases (1100) about $3 / 4$ were treated by a surgeon, $2 / 3$ were hospitalized, 396 operations have been carried out..

The mortality was equal to the national average of $5.4 \%$. The percentages of negative laparotomies (7.3\%) and appendix sana (14.5\%) were low. The majority of the final diagnoses resulted in Non Specific Abdominal Pain (42.6\%). Valuable for the diagnostics is the age: young people in the age of 10-30 years had a much greater chance on Non Specific Abdominal Pain and appendicitis than older people, for which the chance on appendicitis decreased, but for which the overall chance on grave abdominal pathology increased strongly (cholecystitis, vascular diseases, cancer).

In the cases checked in at the Accident \& Emergency Dept. on their own initiative, there appeared to be proportionally twice as much Non Specific Abdominal Pain than in the rest of the patient population.

Although the G.P. is only available for his patients one third of the total time, three quarters of the referrals were carried out by the own G.P. From this it appeared that patients with abdominal complaints in a number of cases delayed the appealing for medical aid. Of all referrals by a G.P., $43 \%$ took place during a consultation in his practice and $57 \%$ after a house call. The percentage of real urgencies amounted to $42.2 \%$, evenly divided over consultations and house calls.

The factor time, the qualifying element of the prognosis, is measured of all 1100 cases. The average time of the pre-clinical stage was 42 hours and 26 minutes, in time followed by the waiting time on operation, at an average of 31 hours and 42 minutes. The involvement of the G.P. took up relatively little time: 1 hour. Of perforated appendicitis the average time of the course of the disease was remarkably much longer than on nonperforated appendicitis. Particularly the pre-clinical stage and the waiting time until the operation were qualifying for this longer period. A sound explanation for this fact is not available: possibly a mixture of delay and less convincing symptomatology.

During analysing of the diagnosis made, it was noticed that it occurred fairly often, especially with regard to the G.P's, that the preliminary diagnoses made, finally appeared to be non-specific. The diagnosis appendicitis made by the G.P's on referral, not only appeared to be impossible to be confirmed in $62 \%$ of the cases, but finally also appeared to be non-specific in $48 \%$ (!). Several explanations are possible for this phenomenon:

1. "upwards pressure" by the patient to be referred or hospitalized; 
2. the fear of the G.P. to make an error or to cause a delay;

3. the possibility that it has been after all (self-limiting) appendicitis.

Furthermore it appeared to be difficult for the G.P. to differentiate between the diagnoses cholecystitis acuta and perforation of a peptic ulcer on the one, and the diagnosis pancreatitis on the other hand. For the specialists it appeared to be easier. The grenter possibility and necessity for additional examination in the hospital are surely of influence on this outcome.

Finally a difference was found of $9 \%$ in favour of the Accident \& Emergency Dept., when comparing the percentage of accurate diagnoses made by the G.P's to those made by the Accident \& Emergency Dept. The overall-percentage of accurate diagnoses appeared to be for the G.P.'s 50\% and for the Accident \& Emergency Dept. $61 \%$ (full patient population).

The most substantial conclusions, emanated from the Acute Abdomen Analysis are:

- during locum tenency the appealing for medical aid at the G.P. was delayed;

- it is possible that more cases are referred back to the G.P. immediately after the first examination at the Accident \& Emergency Dept.;

- in more than one fifth of all admissions to the hospital it appeared afterwards that no cause for the abdominal complaints, open to objectification, could be indicated;

- the obtained percentage of negative laparotomies and appendix sana are to be considered low;

- the chance on severe abdominal pathology increased when aging, and conversely the chance on appendicitis decreased;

- the category of final diagnosis Non Specific Abdominal Pain numerically took the first place;

- with the self-referrers it appeared that proportionally twice as much final diagnoses Non Specific Abdominal Pain occurred as with the cases referred by the G.P. to the Accident \& Emergency Dept;

- measured to the full population, the average time of the stage "from onset up to the moment of check-in at the Accident \& Emergency Dept." was the longest period, followed by the stage, counted from the moment of examination at the Accident \& Emergency Dept. up to the operation;

- in the stage until the check-in at the Accident \& Emergency Dept. the average period of time from the onset until the appeal for medical aid to the G.P. appeared to be the longest; this period was mainly determined by the patient himself or by his or her surroundings;

- self-referrers with acute abdominal complaints sooner check in at the Accident \& Emergency Dept. than patients referred by the G.P.;

- in cases of perforated appendicitis it appeared that there was a much higher average time up to the moment of operation, compared to the unperforated cases;

- the efforts of the G.P.'s, made manifest in the Acute Abdomen Analysis took in the total course of the disease not more than some percents of the total average time;

- the difference in percentages of accurate diagnoses between G.P.'s and the Accident \& Emergency Dept. is $9 \%$; 
- especially on the preliminary diagnosis, made by the G.P.'s, it occurred that particularly the diagnosis appendicitis could often not be confirmed afterwards, having to be classified as Non Specific Abdominal Pain;

- particularly the preliminary diagnosis acute cholecystitis and perforation of a peptic ulcer, made by the G.P."s, afterwards often appeared to be pancreatitis.

The most substantial recommendations are:

- with reference to the importance of the factor "time" at the prognosis of acute abdominal diseases, it ought to be investigated which factors are qualifying, and to what extent, for the delay of the appealing for medical aid at the G.P.;

- it shows of thoughtful policy to discourage the phenomenon of self-referral; taking into account the consequences with regard to the functioning of G.P.'s as well as the Accident \& Emergency Dept., it is also recommended to investigate further the matter of self-referral;

- it is recommended to study further the reasons, leading to a longer average time of the disease on perforated appendicitis in comparison to non-perforated appendicitis;

- investigation to operations research implications of the symptomatology of particularly Non Specific Abdominal Pain, appendicitis, acute cholecystitis, perforation of a peptic ulcer and pancreatitis, have to be stimulated, this with regard to the frequently occurring mutual exchange of these diagnoses;

- the level of the percentage of "accurate diagnoses" justifies efforts to improve the accuracy e.g. by the developing of records and algorithms for the benefit of the diagnostics of acute abdominal diseases. 


\section{LITERATUUR}

ANGELL J.C.(1978)

The acute abdomen for the man on the spot.

Pitman Medical.

BATTERSBY C., CHAPUIS P. (1977)

Acure pancreatitis, the Queensland scene.

Aust.N.Z.J. Surg. 47: 204-209.

BISHOP W.J. (1962)

The early history of surgery.

Oldbourne Book Co Ltd.

BLACKLOCK A.R.E., GUNN A.A. (1976)

The "acute abdomen" in the accident and emergency department.

Coll. Surg. Edinburgh 21, 3: 167.

BOER DE J., et al. (1983)

Leerboek der Chirurgie.

Scheltema \& Holkema B.V.

BOER DE H.H.M. (1986)

Diagnostiek van acute pancreatitis.

Nederlands Tijdschrift voor Geneeskunde 47: 2122 .

BOERHAAVE H. (1709)

Kortstondige spreuken wegens de ziektes.

Stafleu Wetenschappelijke Uitgeversmaatschappij B.V., Alphen aan de Rijn 1979.

BOTSFORD T.W., WILSON R.E. (1977)

The acute abdomen.

W.B. Saunders Company, Philadelphia.

BUCHMAN T., ZUIDEMA G.D. (1984)

Reasons for delay of the diagnosis of acute appendicitis.

Surg. Gynecol.Obst. 158: 260-266.

COPE Z. (1965)

The history of the acute abdomen.

London Oxford Publications.

COPE Z. (1979)

Early diagnosis of the acute abdomen.

Oxford University Press, New York.

DEMOULIN D. (1974)

Syllabi Colleges 1974-1975.

Katholieke Universiteit Nijmegen.

DICK W. (1952)

Uber den Begriff "Akutes Abdomen".

Deutsche medizinische wochenschrift 9: 257, 259.

DOMBAL DE F.T.(1979;1)

Diagnosis decision-making and acute appendicitis.

Der Chirurg 50: 291-296. 
DOMBAL DE F.T. $(1979 ; 2)$

Abdominal pain: an O.M.G.E. study

Scand. J. Gastroent. 14/suppl. 56:34.

DOMBAL DEF.T. (1980)

Diagnosis of acute abdominal pain.

Churchill Livingstone.

DONKER P.J. (1983)

Leerboek Chirurgie onder redactie van Dr. J. de Boer.

Bohn, Scheltema \& Holkema B.V.

DUBECZ S., STEFANICS J., JUNASZ F., PENKOV P. (1976)

Zeigt die Häufigkeit der Appendicitis perforativa eine abnehmende Tendenz?

Zentralblatt Chirurgie 101: 793-798.

EDELSTEIN A. (1974)

Experience and mastery of pain.

Israel Ann. Psychiat. 12: 216-226.

ERASMUS, D. (1509)

De lof der Zotheid

In het Nederlands vertaald door A. Dirkzwager en A.C. Nielson.

Uitgeversmaatschappij Ad Donker B.V. Rotterdam 1986.

FEINSTEIN A. (1967)

Clinical Judgement.

Williams \& Williams, Baltimore.

FUX H.D., BLINDOW D., KIENZLE H.F. (1979)

Das perforierte gastroduodenale Ulkus.

Fortschr.Med. 97/33: 1421-1428.

GAIL K. (1975)

Akute Schmerzen im Oberbauch

Diagnostik 8/3: 92.95.

GIL.MORE O.J.A. (1978)

Diagnostic errors and operative findings in "appendicitis".

Bull.Soc.Int.Chir. 34/6: 654-658.

GRUER R., GUNN A.A., RUXTON A.M. (1977)

Medical audit in practice.

Britisch Medical Journall 1: 957.

GUNN A.A. (1976)

The diagnosis of acute abdominal pain with computer analysis.

J.R.Surg. Edinburgh 21, 3, 170-172.

HAESER H. (1859)

Geschiedenis der Geneeskunde.

Utrecht 1859. Fac Simile. Ronald Meesters, Amsterdam 1980.

HAFFTER D., MEYER N., SCHOLER A., GYR K. (1983)

Der diagnostische Wert der Bestimmung von Serumamylase und Serumlipase bei Verdacht auf akutem Schub einer akuten oder chronischen Pankteatitis.

Schweiz. Med. Wochenschrift 113/5: 184-188. 
HAMPTON J.R., HARRISON M.J.G., MITCHELL J.R.A., PRICHARD J.S., CAROL SEYMOUR (1975)

Relative contributions of history-taken, physical examination and laboratory investigation to diagnosis and management of medical outpatients.

British Medical Journal 2: 486-487.

HARRISON S.(1971)

Principles of internal medicine.

McGraw-Hill Book Company, Sixth Edition.

HELLNER H. (1970)

Lehrbuch der Chirurgie.

Georg Thieme Veriag, Stuttgart.

HERODOTOS. (ca. 400 v.Chr.)

Historiae, Fibula van Dishoek, 1978.

HOFFMANN J., KURGAN A., ABRAMOWITZ H.B. (1983)

Rectal temperature in the diagnosis of lower abdominal pain.

Isr.J.Med.Sci 19(6): 505.7.

HONORÉ P., BELACHEW M., HONORÉ D. (1982)

L'ischaemie intestinale aiguè.

Rev.Med. Liège, 37(21): 743-748.

HOOGENDOORN D. (1987)

Appendicitis; appendectomieën.

Nederlandse Tijdschrift voor Geneeskunde 31: 1351.

ILLICH I.(1975)

Het medisch bedrijf, een bedreiging voor de gezondheid.

Het wereldvenster, Baarn.

ISSELBACHER B. (1971)

Principles of internal medicine.

Onder redactie van Harrison. McGraw-Hill Book Company.

JANZON L., RYDEN C.I., ZEDERTFELDT B. (1982)

Acute abdomen in the surgical emergency-room. Who is taken care of when for what?

Acta Chir.Scand. 148/3: 141.

JESS P., BJERREGAARD B., BRYNITZ S., CHRISTENSEN J.N., KALAJA E., KRISTEN-

SEN J.L., MATZEN P. (1982)

Prognosis of acute Non Specific Abdominal Pain.

Am.J.Surg. 144/3: 338-340.

JOHNSON J.E., RICE V.H. (1974)

Sensory and distress components of pain: implications for the study of clinical pain.

Nurs. Res. 32/2: 203-209.

JORDAN G.L. (1980)

The acute abdomen.

Year Book Medical Publishers Inc, ; 261-264.

KAESS H. (1980)

Akutes Abdomen, Differentialdiagnose und Therapie.

Internist 21(5): 266.

KERN E. (1979)

Das akute Abdomen, Klinik und Diagnostik, allgemeiner Überblick.

Langebecks Arch.Chir. 349, 467. 
KNOTTNERUS J.A. (1985)

De zeeffunctie van de huisarts, het totale plaatje.

The practitioner. Nederlandse Uitgave 12: 2481 .

KNOTTNERUS 』.A. (1988)

Dialectiek van het onderzoek in de huisartsgeneeskunde.

Inaugurale rede aan de Rijksuniversiteit Limburg.

KONING GANS DE H.J., VREELING F.W. (1985)

Het EEG van de acute buik; intermitterende bewustzijnsstoornissen als gevolg van aandoeningen in de buik.

Nederlands Tijdschrift woor Geneeskunde 52: 2481 .

KUIJJER P.J. (1983)

Leerboek der chirurgie onder redactie van Dr. J. de Boer.

Bohn, Scheltema \& Holkema B.V.

LICHTNER S., PFLANZ M. (1971)

Appendectomy in the Federal Republic of Germany.

Medical Care 9: 312 .

LINDEBOOM G.A. (1971)

Inleiding tot de geschiedenis der geneeskunde.

N. Bohn, Haarlem.

McBURNEY C. (1889)

Diagnosis of acute appendicitis.

New York Medical Journal 50: 676.

McKAY C., McKAY H.P. (1976)

Perforated peptic ulcer in the west of Scotland.

British Journal of Surgery 63: 157-158.

MCRAE L. (1970)

Chanell capacity in absolute judgement tasks: an artifact of information bias?

Psychological Bulletin Vol 73, 2: 112,121.

MEETEREN van J. (1985)

Appendicitis acuta; een retrospectieve analyse.

Nederllands Tijdschrift woor Geneeskunde 13: 586.

MELLEGARD M. (1971)

Disease: description and decision.

Dan.Med. Bull. 18: 137-142.

MENGES L.J. (1979)

Pijn en pijnbehandeling.

Uitgeversmaatschappij De Tijdstroom, Lochem Popertinge.

MERKSEY H.J. (1973)

The perception and measurement of pain.

Psychosom.Res. 17: 251-255.

MONDOR A. (1950)

Diagnostiek van de acute aandoeningen der buikorganen.

Scheltema, Holkema, Amsterdam.

MULLER H., HENNEMAN C. (1972)

Spoedeisende gevallen in de interne kliniek.

Agon Elsevier, Amsterdam, vierde druk. 
MUNRO A., JONES P.F. (1975)

Abdominal surgical emergencies in the puerperium.

British Medical Journal 4: 691-694.

OTTOLANDER DEN G.J.H. (1969)

Interne geneeskunde.

Oosthoek's Uitgeversmaatschappij.

PERDIKES P. (1982)

The acute nonsurgical abdomen.

Surg.Annu. 14: 101.

PETIT J.J. (1984)

The acute abdomen.

Medisch proefschrift Rijksuniversiteit Groningen.

PUYLAERT J.B.C.M., RUTGERS H., LALISANG R.I. et al. (1987)

Prospective study of ultrasonography in the diagnosis of appendicitis.

N.Engl.J.Med. 317:666-9.

ROESCH W. (1975)

Rationeller Einsatz diagnostischer Mittel beim akuten Abdomen.

Diagnostik 8/3: 89-91.

ROGERS A.I. (1978)

The acure abdomen.

Compr. Ther. 4/7: 25-27.

SACLARIDES Th., HOPKINS W., DOOLAS A. (1986)

Abdominal emergencies.

Medical Clinics of North America Vol 70, 5: 1094.

SAEGESSER F. (1981)

The acute abdomen.

Clin. Gastroenterol. 10,1: 141-143.

SCHADÉ J.P. (1976)

Compendium neurologie.

Uitgeversmaatschappij De Tijdstroom, Lochem.

SMTT P.Th. (1974)

Spoedeisende gevallen in een huisartsenpraktijk.

Erven Bohn B.V., Amsterdam.

SOBOTTA J., BECHER H. (1965)

Atlas der deskriptiven Anatomie des Menschen.

Urban \& Schwarzenberg, München-Berlin.

STANILAND J.R, DITCHBURN J., DE DOMBAL F.T. (1972)

Clinical presentation of acute abdomen: study of 600 patiënts.

British Medical Journal, 3, 394: 393-398.

STANILAND J.R., CLAMP S.E., DE DOMBAL F.T., SOLHEIM K., HANSEN S., RØNSEN K., HELSINGEN N. (1980)

Presentation and diagnosis of patients with acute abdominal pain: comparisons between Leeds, U.K. and Akershus County, Norway.

Ann. Chir. Gynaecol. 69/6: 245-250.

TÖNDURY G. (1965)

Angewandte und topographische Anatomie.

Georg Thieme Verlag, Stuttgart. 
VERHAGEN P.F., MOSSEVELDE VANP., GERHARDS L.J. (1987)

Een onverwachte oorzaak van acute buikverschingelen bij jonge volwassenen.

Nederlands Tijdschrift woor Geneeskunde 20:841.

VERSCHUEREN R.C.]. (1983)

Leerboek der Chirurgie onder redactie van Dr. J. de Boer.

Scheltema \& Holkema B.V.

VERSCHUYL M.A. (1988)

"Met naald en draad, van mier tot niet"

Serieuitgave van de Reinier de Graaf Stichting te Delft.

Nummer 2.

VIERSMA J.W., VREEKEN J., COST W.S., MANDEMA E. (1972)

Spoedeisende gewallen in de imterne kliniek.

Elsevier.

VOORHOEVE P. (1979)

De fysiologie van de pin.

Pijn en pijnbehandeling.

Uitgeverij de Tijdstroom, Lochem Poperinge.

VOORHOEVE P. (1980)

Neuro-fysiologische overwegingen bii pijn: de grootste gemene deler van verschillende pijntheorieèn.

Symposion Montpellier, Exerpta Medica, Amsterdam-Oxford, Princeron.

WEBER E.M.W. (1960)

Schemata der Leitungsbahnen des Menschen.

F. Lehmanns Verlag, München.

WILSON D.H. (1979)

The acute abdomen in the accident and emergency department.

Practitioner 222(1330): 483 .

WITTEBOL P. (1983)

Leerboek der chirurgie onder redactie van $\mathrm{Dr}$. J de Boer.

Schelterna \& Holkema B.V.

WULFF R. (1980)

Principes van klinisch denken en handelen.

Bohn, Scheltema \& Holkema.

ZETA. (1955)

The diagnosis of the acute abdomen in rhyme.

H.K. Lewis \& Co, Londen. 
World Congress of Gastro-Enterology Survey 1976-77

CLINICAL DIAGNOSIS: ACUTE ABDOMINAL PAIN $<$ I WEEK

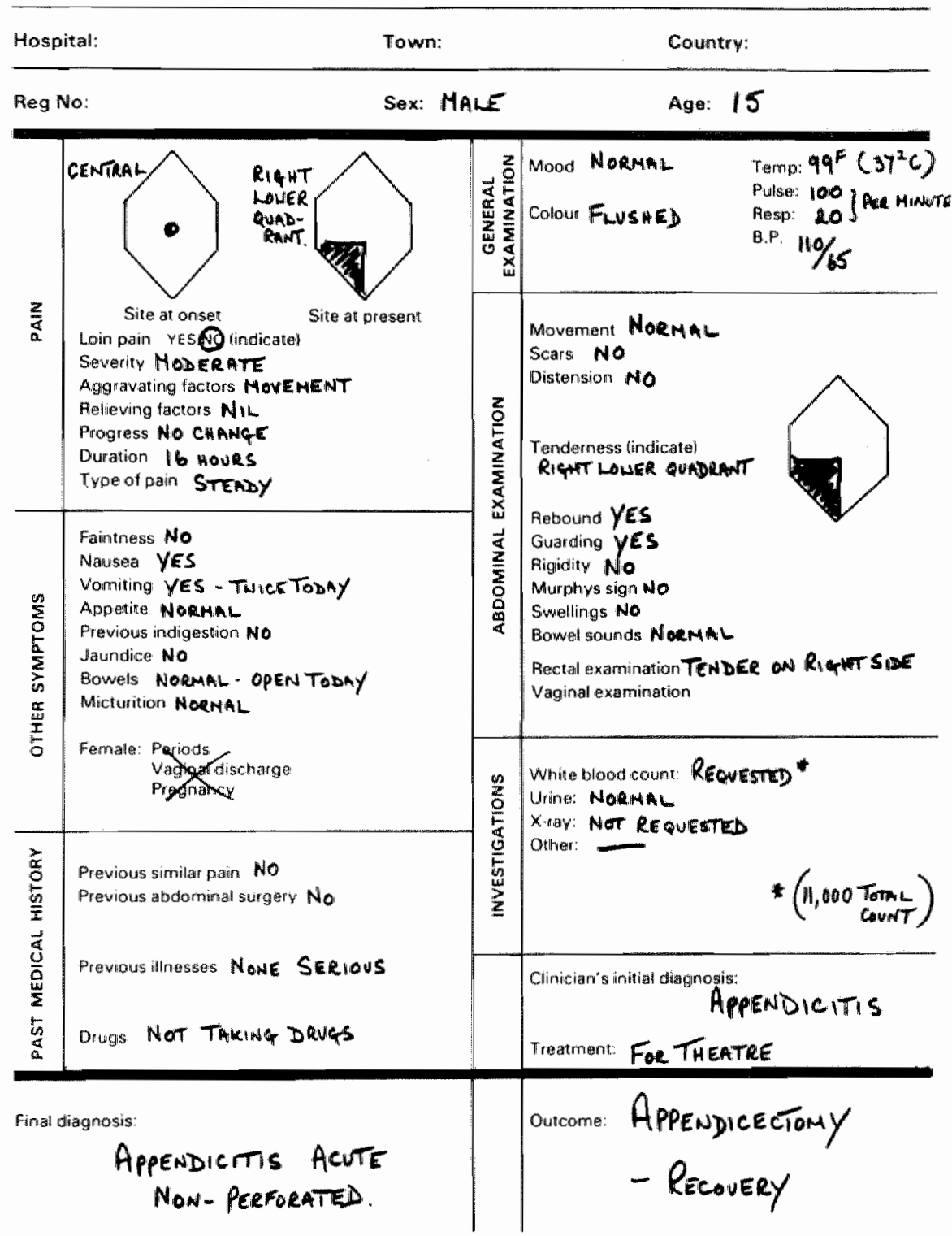

Bijlage 1.

Chek-list, ontwikkeld door het World Congress of Gastro-Enterology Survey 1976-1977. 


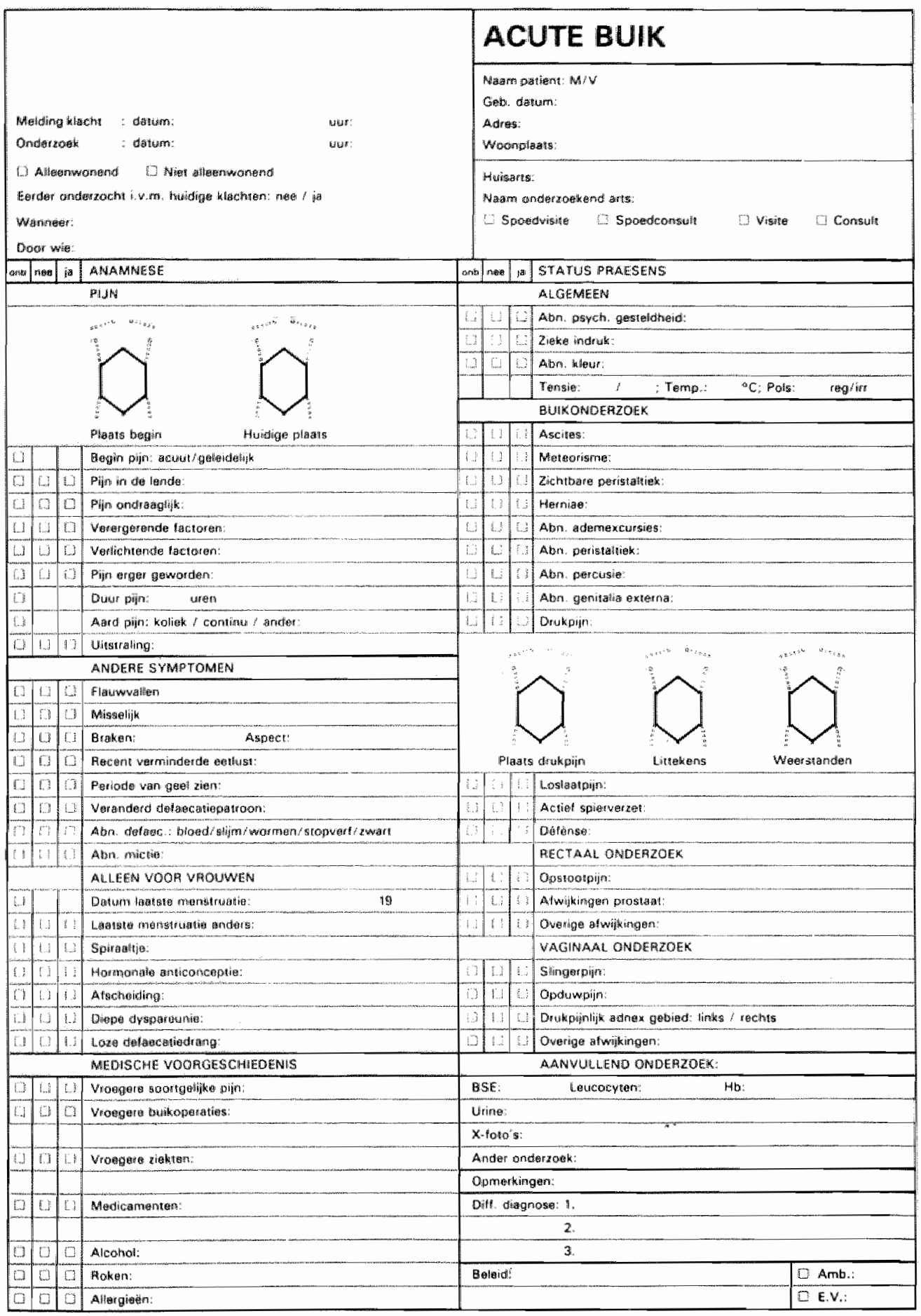

Bijlage 2.

Het huisartsenformulier. 


\section{ZIEKENHUIS ST. ANNADAL, MAASTRICHT}

EHBO/POLU / $\triangle F O$

Darum binnenikamsa:

wete

ABE HEV.
ACUTE BUIK

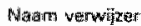

Naen onderzokend orts

Functie:

Tipostip anderzark:

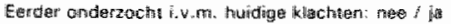

Whanneer:

Door wite:

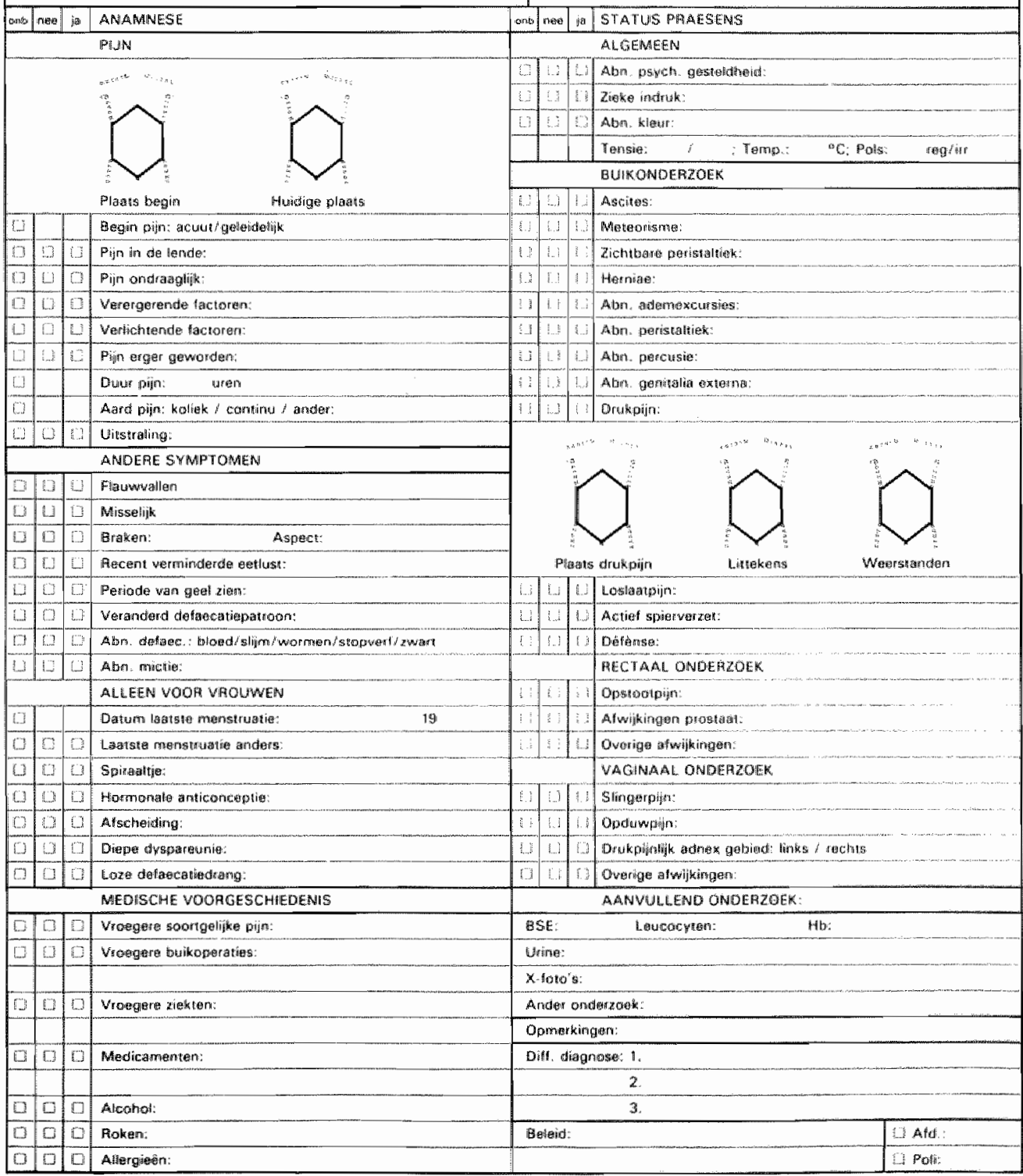

Biilage 3 .

Het specialistenformulier. 


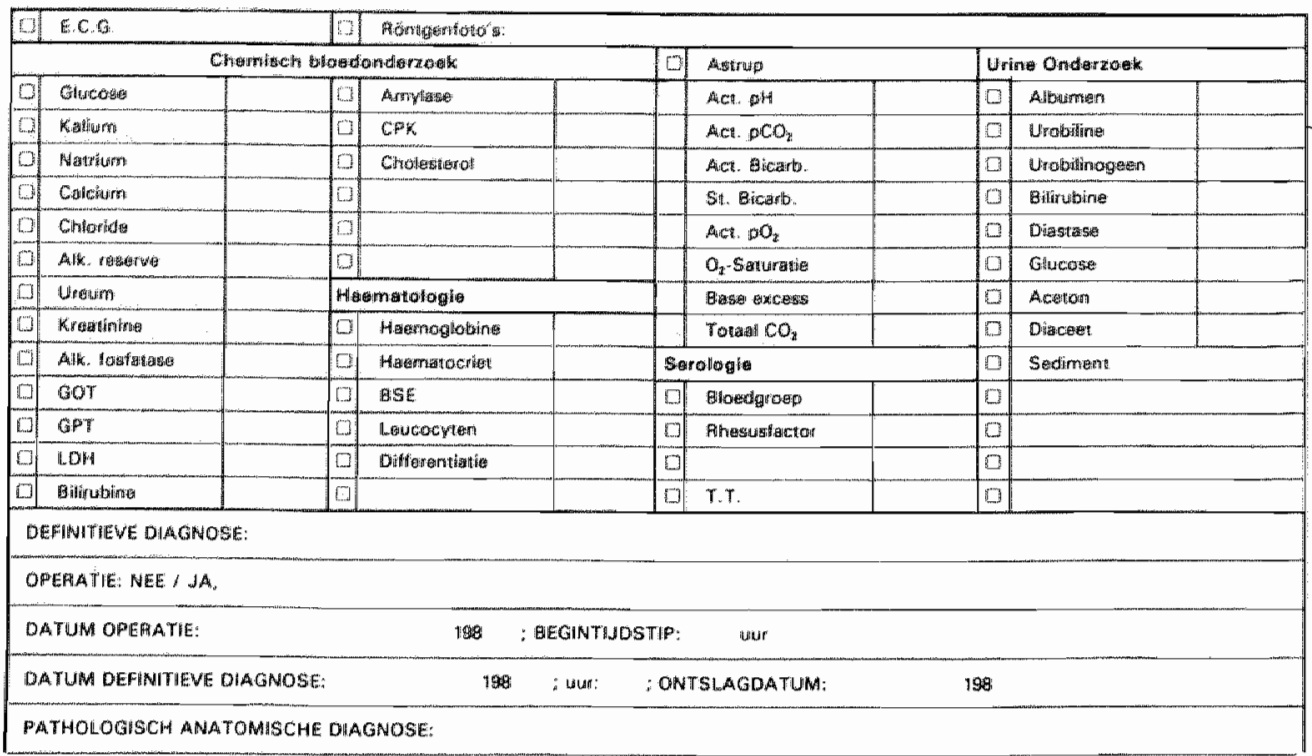

Bijlage 3 at

Keerzinde spectal htenformulier.

Aantal in het zieken-

huis opgenomen

patiënten*

2
2
23
673

Toraal

700

Aantal patienten dat op de polikliniek werell tortugbestelat

Aantal maten onderzoch op de EHBO wegens buikklachten
Total aantal in het ziekenhuis opgenomen casus

$\begin{array}{rr}= & 8 \\ = & 6 \\ = & 46 \\ = & 673\end{array}$

\begin{tabular}{|c|c|c|c|c|c|}
\hline \multicolumn{2}{|l|}{7} & $x$ & 2 & $=$ & 14 \\
\hline \multicolumn{2}{|l|}{297} & $x$ & 1 & $=$ & 297 \\
\hline Totaal & 304 & & & & 311 \\
\hline \multicolumn{2}{|c|}{$\begin{array}{l}\text { Aantal patiënten da: } \\
\text { retour huisarts werd } \\
\text { gestuurd }\end{array}$} & \multicolumn{2}{|c|}{$\begin{array}{l}\text { Aantal malen onderzocht } \\
\text { op de EHBO wegens } \\
\text { buikklachten }\end{array}$} & \multicolumn{2}{|c|}{$\begin{array}{l}\text { Total aancal casus } \\
\text { dat retour huisarts } \\
\text { werd gestuurd }\end{array}$} \\
\hline 56 & & $x$ & 1 & $=$ & 56 \\
\hline Totat & 56 & & & & 56 \\
\hline \multicolumn{4}{|l|}{$\begin{array}{l}\text { Totaal } \\
\text { aantal }\end{array}$} & \multicolumn{2}{|c|}{$\begin{array}{l}\text { Totalal aan- } \\
\text { tal casus }\end{array}$} \\
\hline patienten & 1060 & & & & 1100 \\
\hline
\end{tabular}

Biilage 4.

Aantal patiënten versus antall casus, opnames, retour polikliniek en retour huisarts.

* Alle opnames direct vanuit de EHBO. 


\begin{tabular}{lccccc}
\hline Einddiagnose & Chirurg & Internist & Gynatcoloog & Uroloog & Total \\
\hline NSAP & 262 & 75 & - & - & 337 \\
Appendicicis ac.perf. & 21 & - & - & - & 21 \\
Append. ac.non perf. & 72 & $\left.1^{*}\right)$ & - & - & 73 \\
Appendiculair infiltr. & 20 & 1 & - & - & 21 \\
Cholecystitis acuta & 22 & $\left.3^{\star}\right)$ & - & - & 25 \\
Cholecystitis chr. & 26 & 4 & - & - & 30 \\
Obstructie dunne darm & 28 & 4 & - & - & 32 \\
Perforatic ulcus pept. & 19 & - & - & - & 19 \\
Pancreatitis & 23 & 17 & - & - & 40 \\
Diverticulitis & 11 & 1 & - & - & 12 \\
Urolithiasis & 6 & - & - & 1 & 7 \\
Vasculaire aand. & 12 & - & - & - & 12 \\
Gynaecologische afw. & 16 & 1 & 4 & - & 21 \\
Maligniteit & 9 & 19 & - & - & 28 \\
Overige diagnoses & 85 & 93 & - & - & 178 \\
\hline Totaal aantal & 632 & 219 & 4 & 1 & 856 \\
\hline
\end{tabular}

\section{Biilage 5 .}

Firequentieverdeling categorieën einddiagnoses groep $\mathrm{D}$ en $\mathrm{E}$, uitgesplitst naar het specialisme waarnaar verwezen werd.

* op de EHBO al overgedragen aan de chirurg. Eventuele intercollegiale verwijzingen in een later stadiun zijn in het Maastrichtse onderzoek niet nagegaan.

\begin{tabular}{|c|c|c|c|c|}
\hline Einddiagnose & $\begin{array}{l}\text { Opname zieken- } \\
\text { huis } \\
\text { Aantal }(\%)\end{array}$ & $\begin{array}{l}\text { Revisie poli- } \\
\text { kliniek } \\
\text { Aantal }(\%)\end{array}$ & $\begin{array}{l}\text { Retour huis- } \\
\text { arts } \\
\text { Aantal }(\%)\end{array}$ & $\begin{array}{l}\text { Totaal } \\
(100 \%) \\
\text { Aantal }\end{array}$ \\
\hline NSAP & $164(34,9) 11^{*}$ & $249(53,1)$ & $56(11,9)$ & 469 \\
\hline Append acuta perfor. & $23(100) \mathbb{L}^{*}$ & $-\quad-$ & $-\infty$ & 23 \\
\hline Append.ac non perf. & $92(100)$ & - & $-\cdots$ & 92 \\
\hline Appendiculair infilt. & $24(100)$ & - & - & 24 \\
\hline Cholecystitis acuta & $29(100)$ & - & - & 29 \\
\hline Cholecystitis chr. & $36(100) 2^{\star}$ & - & -- & 36 \\
\hline Obstructie dunne darm & $35(100)$ & - & - & 35 \\
\hline Perforatie ulcus pept. & $20(100)$ & -- & & 20 \\
\hline Pancreatitis & $50(100)$ & - & $-\ldots$ & 50 \\
\hline Diverticulitis & $12(100)$ & - & - & 112 \\
\hline Urolithiasis & $5(29,4)$ & $12(70,6)$ & - - & 17 \\
\hline Vasculaire aand. & $14(100)$ & -- & & 14 \\
\hline Gynaecologische afw. & $26(96,3) 2^{\star}$ & $1(3,7)$ & & 27 \\
\hline Maligniteit & $33(100) \quad 1^{\star}$ & -- & & 33 \\
\hline Overige diagnoses & $191(87,2) 4^{\star}$ & $28(12,8)$ & - & 219 \\
\hline Totaal & $754(68,5)$ & $290(26,4)$ & $56(5,1)$ & 1100 \\
\hline
\end{tabular}

Bijlage 6.

Opname, revisie polikliniek en retour huisarts per categorie einddiagnose. Totale populatie.

* antal = niet direct na onderzoek op de EHBO, maar in tweede instantie tijdens poliklinische controle opgenomen in het ziekenhuis. 


\begin{tabular}{|c|c|c|}
\hline Eind dir & $\begin{array}{l}\text { Operaties } \\
\text { Aamial } \%\end{array}$ & $\begin{array}{l}\text { Totaal } \\
\text { atantal }\end{array}$ \\
\hline NSAP & $29(7,3)$ & 469 \\
\hline Appendicitis acuta perfor. & $23(5,8)$ & 23 \\
\hline Appendicitis actata non perf. & $92(23,2)$ & 92 \\
\hline Appendiculair infiltraat & $3 *(0,8)$ & 24 \\
\hline Cholecystitis acuta & $29(7,3)$ & 29 \\
\hline Cholecystitis chr. & $36(9,1)$ & 36 \\
\hline Obstructic dunne darm & $24(6,1)$ & 35 \\
\hline Perforatie ulcass pept. & $19(4,8)$ & 20 \\
\hline Pancreatitis & $10(2,5)$ & 50 \\
\hline Diverticulitis & $4(1,0)$ & 12 \\
\hline Urolithiasis & $2(0,5)$ & 17 \\
\hline Vasculaire and. & $10(2,5)$ & 14 \\
\hline Gynaecologische afw. & $16(4,0)$ & 27 \\
\hline Maligniteit & $20(5,1)$ & 33 \\
\hline Owerige diagnoses & $79(20,0)$ & 219 \\
\hline Totaal & $396(100)$ & 1100 \\
\hline
\end{tabular}

\section{Biilage 7.}

Operaties per einddiagnose. Totale populatie.

* resterende 21 casus in een later stadium à froid geopereerd. 


\begin{tabular}{cl}
\hline Aantal patiënten & Einddiagnose \\
\hline 1 & Pancreatitis, pancrearitis, pancreatitis, pancreatitis \\
1 & Pancreatis, pancreatitis, pancreatitis, pancreatitis \\
1 & NSAP, NSAP, NSAP \\
1 & Obstructie dunne darm, obstr. dunne darm, obstr. d.darm \\
1 & NSAP, cholecysritits chronica \\
1 & NSAP, appendlicitis non perforata \\
1 & NSAP, appendicitis perforata \\
1 & Obstructie dunne darm, NSAP \\
1 & Carcinoon, rest \\
1 & NSAP, pancreatitis \\
1 & NSAP, rest \\
2 & Appendiculair infiltrat, NSAP \\
$12^{\star}$ & NSAP, NSAP \\
4 & Rest, rest \\
1 & Rest, vasculair \\
2 & Pancreatitis, pancreatitis \\
1 & Obstructie dunne darm, obstructie dunne darm \\
1 & Carcinoom, carcinoom
\end{tabular}

Totaal

\section{Bijlage 8.}

Einddiagnoses, in successie gesteld bij de patiënten die meer dan én keer op de EHBO onderzocht ziin wegens acute buikklachten.

Totale populatie.

* 7 pattënten met NSAP zijn op de polikliniek terugbesteld. De overige 27 patiënten zijn opgenomen in thet ziekenhuis. 
Einddiagnose

Aantal $(\%)$

NSAP

Append. acuta perf.

Append. acuta non perf.

Appendiculair infult.

Chollecystus acuta

Cholecystutis chr.

Obstructie dunne darm

Perforatie ulcus pept.

Pancreatitis acuta

Pancreatitis chr.

Diverticulitis

Urolithiasis

Vasculaire aand.

Gynaccologische af $w$.

Maligniteit

Overige diagnoses
$469(42,6)$

$23(2,1)$

$92(8,4)-(12,7)$

$24(2,2)$

$29(2,5)$

$36(3,3)$

$35(3,2)$

$20(1,8)$

$47(4,3)$

$3(0,3)$

$12(1,1)$

$17(1,5)$

$14(1,3)$

$27(2,4)$

$33(3,0)$

$219(19,9)$

Total

$1100(100,0)$

Bijlage 9.

Categorieèn einddiagnoses.

Totale populatie. 


\begin{tabular}{ll}
\hline Einddiagnose & Bijkomende diagnose \\
\hline Appendicitis acuta perforata & M. Crohn $1 \times$ \\
Cholecystitis acuta & $\begin{array}{l}\text { Lichte pancreatiris }+\operatorname{steen} 1 \times \\
\text { Galstenen } 18 \times\end{array}$ \\
Cholecystitis chronica & Lichte pancrearitis $+\operatorname{steen~} 1 \times$ \\
& Galstenen $22 \times$ \\
Obstructie dunne darm & Maligniteit $4 \times$ \\
& Leiomyoom $1 \times$ \\
Pancreatitis & M. Crohn $1 \times$ \\
Maligniteit & Galstenen $15 \times$ \\
\hline
\end{tabular}

\section{Bijlage 10.}

Meerdere diagnoses aanwezig, meerdere categorieèn einddiagnoses mogelijik. In deze gevallen is steeds gekozen voor die categorie waaronder het ziektebeeld zich tenslotte presenteerde en die later objectief werd bevestigd. Totalle populatie.

\begin{tabular}{|c|c|c|c|c|}
\hline \multirow[t]{2}{*}{ Einddiagnose } & \multirow[t]{2}{*}{$\begin{array}{l}\text { Mortaliteit } \\
\text { operatie } \\
\text { Aantal }(\%)\end{array}$} & \multirow[t]{2}{*}{$\begin{array}{l}\text { Mortaliteit } \\
\text { operatie - } \\
\text { Aantal }(\%)\end{array}$} & \multirow[t]{2}{*}{$\begin{array}{l}\text { Mortaliteit } \\
\text { totaal } \\
\text { Aantal (\%) }\end{array}$} & \multirow[t]{2}{*}{$\begin{array}{l}\text { Totaal } \\
\text { aantal } \\
\text { opnames }(100 \%)\end{array}$} \\
\hline & & & & \\
\hline NSAP & -- & $2(0,2)$ & $2(1,2)$ & 164 \\
\hline App.acuta perf. & - & -- & -- & 23 \\
\hline App.acuta non perf. & - & $-\quad-$ & - & 92 \\
\hline App. infiltraat & -- & $-\quad-$ & -- & 24 \\
\hline Cholecystitis acuta & $-\infty$ & -- & -- & 29 \\
\hline Cholecystiris chr. & - & - & $-\ldots$ & 36 \\
\hline Obstr.dunne darm & $1(2,9)$ & $4(11,4)$ & $5(14,3)$ & 35 \\
\hline Perf.ulcus pept. & $3(15,0)$ & $-\quad-$ & $3(15,0)$ & 20 \\
\hline Pancreatitis & $1(2,0)$ & $3(6,0)$ & $4(8,0)$ & 50 \\
\hline Diverticulitis & $1(8,3)$ & -- & $1(8,3)$ & 12 \\
\hline Urolithiasis & -- & -- & $-\quad-$ & 5 \\
\hline Vasculaire aand. & $5(35,7)$ & $4(28,6)$ & $9(64,2)$ & 14 \\
\hline Gynaecologische afw. & $-\quad-$ & $-\quad-$ & $-\quad-$ & 26 \\
\hline Maligniteit & $4(12,1)$ & $4(12,1)$ & $8(24,2)$ & 33 \\
\hline Overige diagnoses & $6(3,11)$ & $3(1,6)$ & $9(4,7)$ & 191 \\
\hline Totaal & $21(2,7)$ & $20(2,6)$ & $41(5,4)$ & 754 \\
\hline
\end{tabular}

\section{Bijlage 11 .}

Mortaliteit per categorie einddiagnose van de geopereerde en niet geopereerde casus ten opzichte van het atantal opnames. Totale populatie.

Van de aiet opgenomen gevallen is niemand gedurende de periode van poliklinische controle overleden. Van de gevallen die retour huisarts. werden gestuurd is binnen twee weken hierna niemand overleden. 
Gynaecologische aandoeningen

Einddiagnose

Aantal

Einddiagnose

Aancal

Abortuswresten

Adnexitis

Bloedende follikel.

Endometriose

EUG/tuba

Geinfecteerde hydrosalpinx

Gesteeldr.ovariaalcyste

Getordeerde hydrosalpinx

Hyperemesis gravidarum

Ovariumcyste

Ovulatiebloeding

Pan-metritis p.p.

Salpingitis

Torsio tuba

Tuba-ovarieel abces

Totaal

Bijlage 12

Oorzaken gynaecologische en vascullaire aandoeningen. Totale populatie.
Aneurysma aorta abdom.

3

10

1

4

1

1

\section{1}

1

1

1

1

1

1

1

I

Aneurysma takje arteria

hepatica

1

Geruptureerd aneurysma van

de aorta abdominalis

7

Mesenteriaalchrombose

3

$\begin{array}{ll}\text { Totaal } & 14\end{array}$




\begin{tabular}{|c|c|c|c|}
\hline Einddiagnose & Aancal & Einddiagnose & Aantal \\
\hline Adhaesie sigmoid & 1 & Hydronephrose (geen maligniteit) & 1 \\
\hline Appendix epiploica & 1 & Laat wondinfect & 1 \\
\hline Benigne desmoid-rumor & 1 & Lage ileus & 5 \\
\hline Bloeding tr. digestivus & 10 & Longinfiltraat & 2 \\
\hline Buikwandabces & 1 & Longembolie & 1 \\
\hline Bulbitis (scoop + ) & 4 & Lymfocèle & 1 \\
\hline Cholangitis & 1 & Mallory-Weiss & 2 \\
\hline Choledochussteen zonder & & Miltruptuur & 1 \\
\hline ontsteking & 2 & Myocardinfarct & 2 \\
\hline Cholelithiasis zonder & & Observatie buiktrauma & 3 \\
\hline ontsteking & 14 & Oesophagitis & 2 \\
\hline Colinis (scoop + ) & 7 & Ontsteking dunne darm e.c.i. & 1 \\
\hline Coprostasis $(X+)$ & 13 & Ontstoken caecum & 1 \\
\hline Corpus alienum buikwand & 1 & Perforatie ileum & 2 \\
\hline Crohn & 4 & Perforatie Meckel's & \\
\hline Digitalis-intexicatie & 1 & divertikel & 1 \\
\hline Diverticulose & 4 & Perforatie sigmoid & 1 \\
\hline Diverticulose met & & Peritonitis door Salmonella B. & 1 \\
\hline perforatie & 2 & Pneumonie & 2 \\
\hline Duadenitis (scoop + ) & 2 & Pyelonefritis & 1 \\
\hline Enteritis (scoop + ) & 4 & Pyelonefritis gravidarum & 1 \\
\hline Eosinophiele gastro- & & Pyelo-ureterale overgangs- & \\
\hline enteritis & 1 & stenose & 1 \\
\hline Fibrose rond ureter & 1 & Retroperitoneale fibrose & 1 \\
\hline Galblaas-infilltraat & 2 & Retro-rectaal abces & 2 \\
\hline Gastritis (scoop + ) & 13 & Sick-sinus syndroom & 1 \\
\hline Hepatitis & 1 & Sigmoiditis & 6 \\
\hline Hernia cicatricalis & 2 & Stenose ureter & 1 \\
\hline Hernia cicatricalis & & Strictunir pyelum-ureter & $\mathbb{1}$ \\
\hline incarcerata & 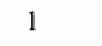 & Sub-ileus (laag) & 9 \\
\hline Hernia femoralis & 1 & Subphrenisch abces & 3 \\
\hline Hernia femoralis & & Torsio testis & 4 \\
\hline incarcerata & 10 & Tubulo-villeus adenoom colon & 1 \\
\hline Hernia inguinalis & 7 & Ulcus duodeni & 14 \\
\hline Hernia inguinalis & & Ulcus pylori & 2 \\
\hline incarcerata & 6 & Ulcus ventriculi & 7 \\
\hline Hernia umbilicalis & 1 & Urine-retentie & 1 \\
\hline Hernia umbilicalis & & Urineweginfectie & 5 \\
\hline incarcerata & 2 & Volvulus caecum & 2 \\
\hline Herpes zoster & 1 & Volvulus dikke darm & 2 \\
\hline \multirow[t]{2}{*}{ Herseninfarct } & 1 & Volvulus sigmoid & 1 \\
\hline & & totaal & 2119 \\
\hline
\end{tabular}

Bijlage 13 .

Onderverdeling van de categorie einddiagnose"overige diagnoses". Totale populatie.

Alle aandoeningen zijn onderbouwd door objectieve bevindingen. 


\section{Einddiagnosc obstruclic dunne darm}

Streng

Maligniteit

Leionyoom

\section{Aantal (\%)}

$30(85,7)$

$4(11,4)$

$1(2,8)$

Totaal

$35(100)$

Bijlage 14.

Oorzaken obstructie dunne darm. Totale populatie.

Einddiagnose pancreatitis

Associatie met galstenen

Associatie met alcohol

Idiopathisch

\section{Aantal $(\%)$}

$15(30,0)$
$10(20,0)$
$25(50,0)$

$50(100)$

Total$$
50(100)
$$

Bijlage 15.

Variaties in mogelijke oorzaken pancreatitis. Totale populatie.

\begin{tabular}{|c|c|c|c|c|c|c|}
\hline $\begin{array}{l}\text { Einddiag- } \\
\text { nose }\end{array}$ & $\begin{array}{l}\text { Tot. } \\
\text { popula- } \\
\text { rie }\end{array}$ & $\begin{array}{l}\text { Niet in } \\
\text { ziekenh. } \\
\text { opgenomen } \\
\text { casus }\end{array}$ & $\begin{array}{l}\text { Klacht } \\
>1 \text { week }\end{array}$ & $\begin{array}{l}\text { Perf.div. } \\
\text { ratimal } \\
\text { hernia }\end{array}$ & $\begin{array}{l}\text { Behandeld } \\
\text { door in- } \\
\text { ternist/ } \\
\text { gynaec./ } \\
\text { uroloog }\end{array}$ & $\begin{array}{l}\text { Vergelijk- } \\
\text { bare popu- } \\
\text { latie }\end{array}$ \\
\hline & Aantal $(\%)$ & Aantal & Aantal & Aantal & Aantal & Aantal $(\%)$ \\
\hline NSAP & $469(42,0)$ & -305 & -2 & - & -12 & $150(26,0)$ \\
\hline Append. & $139(12,6)$ & - & -5 & - & -1 & $133(23,0)$ \\
\hline Chol. & $65(5,9)$ & - & -4 & - & -7 & $54(9,3)$ \\
\hline Ob.d.d. & $35(3,2)$ & - & $-\mathbb{1}$ & - & -4 & $30(5,2)$ \\
\hline Perf.u.p. & $20(1,8)$ & - & - & - & - & $20(3,5)$ \\
\hline Pancr. & $50(4,3)$ & - & - & - & -18 & $32(5,5)$ \\
\hline Divert. & $12(1,1)$ & - & -2 & $+2^{\star}$ & -1 & $11(1,9)$ \\
\hline Overige & $310(28,1)$ & -41 & -33 & -22 & -66 & $148(25,6)$ \\
\hline Total & $1100(100)$ & -346 & -47 & -20 & -109 & $578(100)$ \\
\hline
\end{tabular}

Bijlage 16.

Verwerking totale populatic om met de internationale aantallen te kunnen vergelijken.

$-=$ tuitsluining.

* perforatie colon ten gevolge van diverticulitis. 


\begin{tabular}{|c|c|c|}
\hline $\begin{array}{l}\text { Verwiger in } \\
\text { successie }\end{array}$ & $\begin{array}{l}\text { Einddiagnose in } \\
\text { successie }\end{array}$ & $\begin{array}{l}\text { Tijd tussen } \\
\text { onderzoeken op } \\
\text { de EHBO }\end{array}$ \\
\hline Huisarts*, zelf & NSAP, NSAP & 5 dagen \\
\hline Zelf, zelf & NSAP, NSAP & 1 maand \\
\hline Huisarts, zelf & NSAP, app non perf. & 1 jaar \\
\hline Zelf, zelf & NSAP, NSAP & 2 maanden. \\
\hline Huisarts, zelf & Overige, overige & 7 weken \\
\hline Zelf,zelf & Pancreatitis, pancreatitis & 7 maanden \\
\hline Ha, ha, zelf & NSAP, NSAP, NSAP & 2 maanden, 2 mud. \\
\hline Zelf, zelf & Pancreatitis, pancreacitis & 2 weken \\
\hline Huisarts, zelf & App.filtraat, NSAP & 2 maanden \\
\hline
\end{tabular}

Totaal 9 patiënten

Bijlage 17.

Patiënten die vaker op de EHBO geweest zijn met acute buikklachten en zich minstens énmatal zelf hebben verwezen. Verwijzer, einddiagnoses en tijdsinterval tussen verschillende onderzoeken. Totale populatie.

* kan ook waarnemend huisarts zijin.

GROEPA GROEPC, D\&E

\begin{tabular}{|c|c|c|c|c|c|c|}
\hline $\begin{array}{l}\text { Op EHBO } \\
\text { gestelde } \\
\text { diagnose }\end{array}$ & Aantal $(\%)$ & $\begin{array}{l}\text { Geen } \\
\text { opname } \\
\text { Aantal (\%) }\end{array}$ & Aantal $(\%)$ & Aantal $(\%)$ & $\begin{array}{l}\text { Gieen } \\
\text { opname } \\
\text { Aantal (\%) }\end{array}$ & Aantal $(\%)$ \\
\hline Geen/NSAP & $2(3)$ & $73(98)^{\star}$ & $75(100)$ & $18(9)$ & $182(91)$ & $200(100)$ \\
\hline Operige & $70(82)$ & $15(18)$ & $85(100)$ & $64.1(90)$ & $68(10)$ & $709(100)$ \\
\hline Totaal & $72(45)$ & $88(55)$ & $160(100)$ & $659(73)$ & $250(27)$ & $909(100)$ \\
\hline
\end{tabular}

Biillage 18 .

Geen diagnose/NSAP, opname/geen oprame. Groep A versus groep $C, D$ en $E$.

* terugverwijzing vamuit de EHBO naar de huisarts is voor $100 \%$ geen/NSAP. 


\begin{tabular}{|c|c|c|}
\hline Einddiagnose & $\begin{array}{l}\text { Zelfuerwizers } \\
\text { (groep A) } \\
\text { Aantal }(\%)\end{array}$ & $\begin{array}{l}\text { Door huisarts werwezen } \\
\text { (groep }, \mathrm{D} \text { \& } \mathrm{E}) \\
\text { Aantal }(\%)\end{array}$ \\
\hline $\mathbb{N S A P}$ & $103(64,4)$ & $354(38,9)$ \\
\hline Appendicins & $9(5,6)$ & $128(14,0)$ \\
\hline Cholecystitus & $1(0,6)$ & $62(6,9)$ \\
\hline Obstr dunne darm & $1(0,6)$ & $32(3,5)$ \\
\hline Geperfulcus pept. & -- & $20(2,2)$ \\
\hline Pancreatitis & $7(4,4)$ & $40(4,4)$ \\
\hline Diwerticulitis & $-\quad-$ & $12(1,2)$ \\
\hline Oyerige & $39(24,2)$ & $261(28,7)$ \\
\hline Totaal & $160(100)$ & $909(100)$ \\
\hline
\end{tabular}

Bijlage 19.

Einddiagnoses. Groep A versus groep $C_{x} D$ en $E$.

\begin{tabular}{lcc}
\hline Einddiagnose & $\begin{array}{c}\text { Groep E } \\
\text { Aantal }(\%)\end{array}$ & $\begin{array}{c}\text { Groep D } \\
\text { Aantal }(\%)\end{array}$ \\
\hline NSAP & $215(38,1)$ & $122(41,8)$ \\
Appendicitis acuta perf. & $20(3,5)$ & $1(0,3)$ \\
Appendicitis acuta non perf. & $60(10,6)$ & $13(4,4)$ \\
Appendiculair infiltrat & $19(3,4)$ & $2(0,7)$ \\
Cholecystitis ucuta & $16(2,8)$ & $9(3,0)$ \\
Cholecystitis chronica & $19(3,4)$ & $11(3,8)$ \\
Obstructie dunne darm & $21(3,7)$ & $11(3,8)$ \\
Perf. ulcus pept. & $19(3,4)$ & - \\
Pancreatitis & $27(4,8)$ & $13(4,5)$ \\
Diverticulitis & $8(1,4)$ & $4(1,4)$ \\
Urolithiasis & $5(0,9)$ & $2(0,7)$ \\
Vasculaire aandoeningen & $10(1,8)$ & $2(0,7)$ \\
Gyngecologische afw. & $10(1,8)$ & $11(3,8)$ \\
Maligniteit & $13(2,3)$ & $15(5,1)$ \\
Overige diagnoses & $102(18,0)$ & $76(26,0)$ \\
\hline Totaal & $564(100)$ & $292(100)$ \\
\hline
\end{tabular}

Bijlage 20.

Categorieën einddiagnose. Groep E versus groep D. 


\begin{tabular}{lrr}
\hline $\begin{array}{l}\text { Aanvankelijk gestelde } \\
\text { diagnose }\end{array}$ & $\begin{array}{c}\text { Groep E } \\
\text { Aantal }(\%)\end{array}$ & $\begin{array}{c}\text { Groep D } \\
\text { Asntal }(\%)\end{array}$ \\
\hline NSAP & $60(10,6)$ & $105(35,9)$ \\
Appendicitis acuta & $214(37,9)$ & $42(14,4)$ \\
Appendiculair intilitraat & $13(2,3)$ & $5(1,7)$ \\
Cholecystitis acuta & $25(4,4)$ & $16(5,5)$ \\
Cholecystitis chronica & $20(3,5)$ & $13(4,4)$ \\
Obstructie dunne darm & $16(2,8)$ & $12(4,1)$ \\
Perfor. ulcus pept. & $32(5,6)$ & $6(2,0)$ \\
Pancreatitis & $29(5,1)$ & $6(2,0)$ \\
Diverticulitis & $10(1,8)$ & $6(2,0)$ \\
Urolithiasis & $13(2,3)$ & $5(1,7)$ \\
Vasculaire aandoeningen & $9(1,6)$ & $2(0,7)$ \\
Gynaecologische afw. & $13(2,3)$ & $6(2,0)$ \\
Maligniteit & $4(0,7)$ & $9(3,1)$ \\
Overige diagnoses & $106(18,7)$ & $59(20,2)$ \\
\hline Total & $564(100)$ & $292(100)$ \\
\hline
\end{tabular}

Bijlage 21 .

Aanvankelijk door huisartsen gestelde diagnose.

Groep E versus groep D.

\begin{tabular}{|c|c|c|c|c|c|c|c|c|}
\hline \multirow[t]{3}{*}{ Einddiagnose } & \multirow{3}{*}{$\begin{array}{l}\text { Groep E } \\
\text { Waarneming } \\
\text { Aantal }(\%)\end{array}$} & \multirow{3}{*}{$\begin{array}{l}\text { Tot. } \\
100 \%\end{array}$} & \multirow{2}{*}{$\begin{array}{l}\text { Groep D } \\
\text { Waarneming }\end{array}$} & \multirow{3}{*}{$\begin{array}{l}\text { Tot. } \\
100 \%\end{array}$} & \multirow{3}{*}{$\begin{array}{l}\text { Groep } C \\
\text { Waarneming } \\
\text { Aantal }(\%)\end{array}$} & \multirow{3}{*}{$\begin{array}{l}\text { Tot. } \\
100 \%\end{array}$} & \multicolumn{2}{|c|}{ Groep C, D \& E } \\
\hline & & & & & & & Waarneming & $\begin{array}{l}\text { Totaal } \\
100 \%\end{array}$ \\
\hline & & & Aantal $(\%)$ & & & & Aantal $(\%)$ & \\
\hline NSAP & $53(24,6)$ & 215 & $34(27,8)$ & 122 & $8(47,0)$ & 17 & $95(26,8)$ & 354 \\
\hline App.perforata & $6(30,0)$ & 20 & $1(100)$ & $\mathbb{1}$ & - & - & $7(33,3)$ & 21 \\
\hline App.non perf. & $13(21,7)$ & 60 & $4(30,0)$ & 13 & ]. $(9,0)$ & 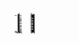 & $18(21,4)$ & 84 \\
\hline App infiltraat & $3(15,8)$ & 19 & $-\quad-$ & 2 & (. $(50,0)$ & 2 & $4(17,4)$ & 23 \\
\hline Cholecyst acuta & $6(37,5)$ & 16 & $1(1,1,0)$ & 9 & - & 1 & $7(26,9)$ & 26 \\
\hline Cholecyst.chron. & $6(31,6)$ & 19 & $3(27,0)$ & 11 & $1(25,0)$ & 6 & $10(27,8)$ & 36 \\
\hline Obstr.dunne darm & $2(9,5)$ & 21 & $2(18,1)$ & 11 & $-\quad-$ & - & $4(12,5)$ & 32 \\
\hline Pert.ulcus pept. & $9(47,4)$ & 19 & - & - & $-\quad-$ & 1 & $9(45,0)$ & 20 \\
\hline Pancreatitis & $14(51,8)$ & 27 & $1(7,6)$ & 13 & - & - & $15(37,4)$ & 40 \\
\hline Diverticulitis & $1(12,5)$ & 8 & - & 4 & - & - & $1(8,3)$ & 12 \\
\hline Urolithiasis & $1(20,0)$ & 5 & $1(50,0)$ & 2 & - & 1 & $2(25,0)$ & 8 \\
\hline Vasculaire aand. & $6(60,0)$ & 10 & $1(50,0)$ & 2 & - & - & $7(58,3)$ & 12 \\
\hline Gynaecol. afw. & $2(20,0)$ & 10 & $2(18,1)$ & 11 & - & 1 & $4(18,1)$ & 22 \\
\hline Maligniteit & $\mathbb{1}(7,7)$ & 13 & $2(13,3)$ & 15 & - - & 3 & $3(9,6)$ & 31 \\
\hline Overige diagn. & $28(27,4)$ & 102 & $21(27,6)$ & 76 & $3(30,0)$ & 10 & $52(27,6)$ & 188 \\
\hline Totaal & $151(26,8)$ & 564 & $73(25,0)$ & 292 & $14(26,4)$ & 53 & $238(26,2)$ & 909 \\
\hline
\end{tabular}

Bijlage 22.

Waarneming per categorie einddiagnose voor groep $\mathrm{E}$, groep $\mathrm{D}$, groep $\mathrm{C}$ en de groepen $\mathrm{C}, \mathrm{D} \& \mathrm{E}$ samen. 


\begin{tabular}{|c|c|c|c|c|c|c|c|}
\hline & \multicolumn{3}{|c|}{ GEEV SPOED } & \multicolumn{4}{|l|}{ SPOED } \\
\hline & Consult & Visite & Totaal & $\begin{array}{l}\text { Spoed } \\
\text { consult }\end{array}$ & $\begin{array}{l}\text { Spoed } \\
\text { visite }\end{array}$ & Totaal & $\begin{array}{l}\text { Tot. } \\
(100 \%)\end{array}$ \\
\hline & Aancal $(\%)$ & Aantal $(\%)$ & Aantal $(\%)$ & Aantal $(\%)$ & Aantal $(\%)$ & Aantal $(\%)$ & Aantal \\
\hline NSAP & $78(36,2)$ & $43(20,0)$ & $121(56,3)$ & $57(26,5)$ & $37(17,2)$ & $94(43,7)$ & 215 \\
\hline Appendicitis & $23(23,2)$ & $33(33,3)$ & $56(56,5)$ & $24(24,3)$ & $19(19,1)$ & $43(43,4)$ & 99 \\
\hline Cholecystitis & $4(11,4)$ & $18(51,4)$ & $22(62,8)$ & $2(5,7)$ & $11(31,4)$ & $13(37,1)$ & 35 \\
\hline Obstr. dunne darm & $1(4,8)$ & $12(57,0)$ & $13(61,9)$ & $1(4,8)$ & $7(33,3)$ & $8(38,1)$ & 21 \\
\hline Purf. ulcus pept. & $-\quad-$ & $7(36,8)$ & $7(36,8)$ & - & $12(63,2)$ & $12(63,2)$ & 19 \\
\hline Pancreatitis & $5(18,5)$ & $\$ 1(40,7)$ & $16(59,2)$ & $1(3,7)$ & $10(37,0)$ & $\mathbb{1 1}(40,7)$ & 27 \\
\hline Diverticulitis & $2(25,0)$ & $3(37,5)$ & $5(62,5)$ & $-\quad$ & $3(37,5)$ & $3(37,5)$ & 8 \\
\hline Urolithiasis & $1(20,0)$ & $1(20,0)$ & $2(40,0)$ & $3(60,0)$ & $-\quad-$ & $3(60,0)$ & 5 \\
\hline Vasculaire aand. & $1(10,0)$ & $1(10,0)$ & $2(20,0)$ & $4(40,0)$ & $4(40,0)$ & $8(80,0)$ & 10 \\
\hline Gynaecol, afw. & $S(50,0)$ & $2(20,0)$ & $7(70,0)$ & $3(30,0)$ & $-\quad-$ & $3(30,0)$ & 10 \\
\hline Maligniteit & $1(7,7)$ & $7(53,8)$ & $8(61,5)$ & - & $5(38,5)$ & $5(38,5)$ & 13 \\
\hline Owerige diagn. & $15(14,7)$ & $52(50,9)$ & $67(65,6)$ & $12(11,8)$ & $23(22,5)$ & $35(34,3)$ & 102 \\
\hline Totaal & $136(24,1)$ & $190(33,7)$ & $326(57,8)$ & $107(19,0)$ & $131(23,2)$ & $238(42,2)$ & 564 \\
\hline
\end{tabular}

Biilage 23.

Spoed/geen spoed per categorie einddiagnose. Groep E.

\begin{tabular}{lccc}
\hline Einddiagnose & $\begin{array}{l}\text { Consult } \\
\text { Aantal }(\%)\end{array}$ & $\begin{array}{l}\text { Visite } \\
\text { Aantal }(\%)\end{array}$ & $\begin{array}{l}\text { Totaal }(100 \%) \\
\text { Aantal }\end{array}$ \\
\hline NSAP & $135(62,8)$ & $80(37,2)$ & 215 \\
Appendicitis & $47(47,8)$ & $52(52,5)$ & 99 \\
Cholecytitis & $6(17,1)$ & $29(82,8)$ & 35 \\
Obstr. dunne darm & $2(9,5)$ & $19(90,6)$ & 21 \\
Perf.ulcus pept. & -- & $19(100)$ & 19 \\
Patncreatitis & $6(22,2)$ & $21(77,7)$ & 27 \\
Diverticulitis & $2(25,0)$ & $6(75,0)$ & 8 \\
Urolithiasis & $4(80,0)$ & $1(20,0)$ & 10 \\
Vusculaireaand. & $5(50,0)$ & $5(50,0)$ & 10 \\
Gynaecol.afw. & $8(80,0)$ & $2(20,0)$ & 13 \\
Maligniteit & $1(7,7)$ & $12(92,3)$ & 102 \\
Overige diagnoses & $27(26,5)$ & $75(73,5)$ & 564 \\
\hline Total & $243(43,0)$ & $321(56,9)$ & \\
\hline
\end{tabular}

Bijlage 24.

Consullten/visites per categorie einddiagnose. Groep $\mathrm{E}$. 


\begin{tabular}{lrc}
\hline Einddiagnose & Aantal $(\%)$ & $\begin{array}{c}\text { Total } \\
\text { aantal }(100 \%)\end{array}$ \\
\hline NSAP & $59(27,4)$ & 215 \\
Appendic.acutat & $25 *(31,2)$ & 80 \\
Appendic.infiltr. & $5(26,3)$ & 19 \\
Cholecyst.acuta & $8(50,0)$ & 16 \\
Cholecyst.chron. & $9(47,3)$ & 19 \\
Obstr. dunne darm & $10(47,6)$ & 21 \\
Perforatie ulcus & $3(15,8)$ & 19 \\
Pancreatitis & $11(40,7)$ & 27 \\
Diverticulitis & $4(50,0)$ & 8 \\
Urolithiasis & $1(20,0)$ & 5 \\
Vasculaire aand. & $2(20,0)$ & 10 \\
Gynaccol. afw. & $4(40,0)$ & 10 \\
Maligniteí & $5(38,5)$ & 13 \\
Overige diagnoses & $35(34,3)$ & 102 \\
\hline Totaal & $181(32,1)$ & 564 \\
\hline
\end{tabular}

Bijlage 25.

Per categorie einddiagnose, de casus welke in de week voorafgande aan verwijzing al een of meerdere malen woor dezelfide klachten door een of meerdere huisartsen werden onderzocht. Groep E.

* 5 perforaties

\begin{tabular}{|c|c|c|}
\hline $\begin{array}{l}\text { Aantal malen door } \\
\text { een huisarts onderzocht } \\
\text { voor verwijzing }\end{array}$ & Einddiagnose & $\begin{array}{l}\text { totaal } \\
\text { aantal } \\
\text { casus }\end{array}$ \\
\hline 3 maal & $\begin{array}{l}\text { NSAP } 1 \times \text {, app infiltr. } 1 \times \text {, pancreatitis } 1 \times \text {, } \\
\text { overige } 1 \times\end{array}$ & 4 \\
\hline 2 maal & $\begin{array}{l}\text { NSAP } 8 \times \text {, appendicitis non perf. } 3 \times \text {, obstructie dunne } \\
\text { darn } 1 \times \text {, gynaecologische af } w .1 \times \text {, owerige } 1 \times\end{array}$ & 14 \\
\hline 1 maal: & Alle andere diagnoses & 163 \\
\hline Total & & 181 \\
\hline
\end{tabular}

Bijlage 26.

Aantal onderzoeken door een huisarts in de week voorafgande aan verwijzing per einddiagnose. Groep E.

\begin{tabular}{lcc}
\hline Einddiagnose & Aantal $(\%)$ & Totaal $(\%)$ \\
\hline NSAP & $14(13,6)$ & $103(100)$ \\
Appendicitis acuta & $2(22,2)$ & $9(100)$ \\
non perforata & $5^{\star}(10,4)$ & $48(100)$ \\
Overige & $21(13,1)$ & $160(100)$ \\
\hline Totaal & & \\
\hline
\end{tabular}

Bijlage 26a.

Een of meerdere malen door een huisarts onderzocht in de week voorafgaande aan het eerste contact met de

EHBO. Groep A.

* $2 \times$ coprostatis; $1 \times$ torsio testis $(>\mathbb{1}$ week); $1 \times$ ulcus duodeni; $1 \times$ hernia inguinalis. 


\begin{tabular}{|c|c|c|c|c|c|c|c|c|c|c|c|c|c|}
\hline $\begin{array}{l}\text { Einddiag- } \\
\text { nose }\end{array}$ & $\$ 10^{\circ}$ & $\begin{array}{l}11 \\
20^{*}\end{array}$ & $\begin{array}{l}21- \\
30^{\prime}\end{array}$ & $\begin{array}{l}31 . \\
45^{*}\end{array}$ & $\begin{array}{l}46 \\
60^{3}\end{array}$ & $\begin{array}{l}1- \\
20\end{array}$ & $\begin{array}{l}2- \\
4 u\end{array}$ & $\begin{array}{l}4-1 \\
8 u\end{array}$ & $\begin{array}{l}8- \\
12 u\end{array}$ & $\begin{array}{l}12- \\
24 u\end{array}$ & $\begin{array}{l}24 \\
1 w k\end{array}$ & $>1 \mathrm{wk}$ & $\begin{array}{l}\text { Totaal } \\
\text { aantal }\end{array}$ \\
\hline NSAP & - & 2 & 4 & 2 & 8 & 35 & 61 & 61 & 52 & 63 & 137 & 44 & 469 \\
\hline App.perf. & - & - & 1 & - & - & 2 & - & 4 & 1 & 7 & 7 & 1 & 23 \\
\hline App.n.perf. & - & - & - & - & - & - & 7 & 14 & 16 & 28 & 26 & 1 & 92 \\
\hline Appofinf & - & - & - & - & - & - & 1 & 2 & 1 & 3 & 14 & 3 & 24 \\
\hline Chol ac. & - & - & - & - & - & $\ldots$ & 4 & 1 & 10 & 4 & 10 & - & 29 \\
\hline Chol chr. & - & - & - & - & 1 & 5 & 3 & 3 & 1 & 9 & 11 & 3 & 36 \\
\hline Obs.d.d. & - & - & 1 & 1 & - & - & 8 & 5 & 1 & 3 & 15 & 1 & 35 \\
\hline Pep.nlous & - & - & - & - & 1 & 1 & 5 & 2 & 6 & 1 & 4 & - & 20 \\
\hline Pancreal. & - & - & 2 & - & 1 & - & 4 & 10 & 2 & 12 & 19 & - & 50 \\
\hline Divertic. & - & - & - & - & - & - & 1 & 1 & 2 & 1 & 5 & 2 & 12 \\
\hline Urolith. & - & - & - & - & 2 & - & 6 & 5 & 2 & 2 & - & - & 17 \\
\hline Vasc.afw. & - & 1 & 1 & - & 2 & - & 3 & 2 & - & 3 & 1 & 1 & 14 \\
\hline Gynafw. & - & - & - & - & 1 & 1 & 2 & 1 & 5 & 2 & 10 & 5 & 27 \\
\hline Malign. & - & - & - & - & - & - & 2 & 2 & 4 & 1 & 9 & 15 & 33 \\
\hline Overiged. & - & - & 2 & - & 1 & 13 & 18 & 23 & 26 & 26 & 84 & 26 & 219 \\
\hline Totaal & - & 3 & 11 & 3 & 17 & 57 & 125 & 136 & 129 & 165 & 351 & 103 & 1100 \\
\hline
\end{tabular}

Biilage 27.

Frequentieverdeling pre-klinische fase in tijdseenheden per categorie einddiagnose. Totalle populatie.

Einddiagnose

Gemiddelde durir

begin klacht/binnenkomst EHBO

NSAP

Appendicitis perf.

Appendicitis non perf.

Appendicinis infiltr.

Cholecystitis acuta

Cholecystitis chrom.

Obstr. dunne darm

Pert. ulcus pept.

Pancreatinis

Diverticulitis

Urolithiasis

Vasculaire aand.

Gynaecologische afw.

Maligniteit

Overige diagnoses
40 uur, 6 minuten

36 uur, 36 minutert

29 uur, 20 minuten

70 usur, 29 minuten

31 uur, 6 minuten

36 uur, 20 minuten

38 vur, 30 minuten

19 uur, 42 minuten

33 uur, 30 minuten

59 uur, 12 minuten

6 uur, 48 minuten

21 uur, 30 minuten

58 uur, 30 minuten

91 uur

49 uur, 54 minuten

Totatal

42 uur, 26 minuten.

Bijlage 28.

Gemiddelde duur pre-klinische fase per categorie einddiagnose. Totale populatie. 


\begin{tabular}{|c|c|c|c|c|c|c|c|c|}
\hline Einddiagnose & $\leqslant 10^{\circ}$ & $11-20^{2}$ & $21-30^{2}$ & $31-45^{\prime}$ & $46-60^{3}$ & $1-2 \mathrm{u}$ & $2.4 u$ & $\begin{array}{l}\text { Total } \\
\text { atantal }\end{array}$ \\
\hline NSAP & 135 & 270 & 44 & 10 & 8 & 1 & 1 & 469 \\
\hline App perf. & 7 & 10 & 3 & 2 & - & 1 & - & 23 \\
\hline App.non perf. & 38 & 38 & 10 & 4 & 2 & - & - & 92 \\
\hline App.infiltr. & 10 & 9 & 3 & 1 & - & 1 & - & 24 \\
\hline Cholec.ac. & 14 & 6 & 7 & 2 & - & - & - & 29 \\
\hline Cholec.chr. & 14 & 10 & 6 & 2 & 2 & 1 & 1 & 36 \\
\hline Obs.dunned. & 20 & 8 & 5 & - & 1 & - & 1 & 35 \\
\hline Perf.ulcus & 16 & 2 & 1 & - & 1 & - & - & 20 \\
\hline Pancreatitis & 24 & 16 & 4 & 4 & 1 & - & $\|$ & 50 \\
\hline Diverriculit. & 4 & 3 & 2 & 1 & 1 & 1 & - & 12 \\
\hline Urolithiasis & 9 & 6 & 1 & - & 1 & - & - & 17 \\
\hline Vascul.afw. & 12 & 2 & - & - & - & - & - & 14 \\
\hline Gynaec.afw. & 7 & 16 & 1 & 1 & 1 & ] & - & 27 \\
\hline Maligniteic & 7 & 12 & 12 & 1 & 1 & - & - & 33 \\
\hline Overige diagn. & 89 & 77 & 41 & 4 & 4 & 3 & 1 & 219 \\
\hline Totaal & 406 & 485 & 140 & 32 & 23 & 9 & 5 & 1100 \\
\hline
\end{tabular}

Bijlage 29.

Frequentieverdeling fase 4 in tijdseenheden per categorie einddiagnose. Totale populatie.

Einddiagnose

Gemictdelde duur

binnemkomst EHBO/onderzoek EHBO

NSAP

Appendicitis perforata

12 minuten

Appendicitis non perf.

14 minuten

Appendiculair infiltraat

13 minuten

Cholecystitis acuta

18 minuten

Cholecystitis chr.

10 minuten

Obstructie dunne darm

20 minuten

Perf.ulcus pepricum

15 minuten

Pancreatitis

8 minuten

Diverticulitis

12 minuten

Urolithiasis

30 minuten

Vasculaire aandoening

12 minuter

5 minuten

Gynaecologische afw.

18 minuten

Maligniteit

19 minuten

Overige diagnoses

17 minuten

Total

15 minuten

Biilage 30 .

Gemiddelde duur fase 4 per categorie einddiagnose. Totale populatie. 


\begin{tabular}{|c|c|c|c|c|c|c|c|c|c|}
\hline Einddiagnose & $46-60^{\prime}$ & $1-2 u$ & $2-4 \mathrm{u}$ & $48 \mathrm{du}$ & $8-12 \mathrm{u}$ & $12-24 u$ & $>24 u$ & I week & $\begin{array}{l}\text { Totaal } \\
\text { aantal }\end{array}$ \\
\hline NSAP & $\ldots$ & - & 2 & 7 & 1 & 7 & 9 & 3 & 29 \\
\hline App.perf. & - & - & - & - & 2 & 8 & 13 & - & 23 \\
\hline App non perf. & - & - & 4 & 11 & 18 & 27 & 30 & 2 & 92 \\
\hline App.infiltr. & - & - & 1 & - & 1 & - & 1 & - & 3 \\
\hline Cholec.acuta & - & - & - & 5 & 7 & 5 & 12 & - & 29 \\
\hline Cholec chr: & - & 3 & 6 & 3 & 2 & 8 & 11 & 3 & 36 \\
\hline Obst.dunted. & - & 1 & 3 & 1 & 2 & 4 & 12 & 1 & 24 \\
\hline Perfulcus & - & 1 & 6 & 4 & - & - & 8 & - & 19 \\
\hline Pancreatitis & - & - & - & 5 & 1 & - & 4 & - & 10 \\
\hline Diverticulit. & - & - & - & 1 & - & 1 & $\mathbb{1}$ & 1 & 4 \\
\hline Urolithiasis & - & 1 & - & - & - & - & $\mathbb{1}$ & - & 2 \\
\hline Gynafiw. & - & 3 & 1 & 2 & 2 & - & 6 & 2 & 16 \\
\hline Mallignirteit & - & - & 2 & 2 & 3 & - & 4 & 9 & 20 \\
\hline Overige diag. & 2 & 8 & 7 & 9 & 6 & 13 & 27 & 7 & 79 \\
\hline Totaal & 4 & 17 & 33 & 51 & 47 & 73 & 142 & 29 & 396 \\
\hline
\end{tabular}

Bijlage 31 .

Frequentieverdeling pre-klinische fase in tijdseenheden per categorie einddiagnose bij de geopereerden. Totale populatie.

\begin{tabular}{ll}
\hline Einddiagnose & $\begin{array}{l}\text { Gemiddelde duur begin } \\
\text { klacht/onderzoek EHBO }\end{array}$
\end{tabular}

NSAP

Appenditicis perforata

Appendicitis non perf.

Appendiculair infiltrnat

Cholecystitis acuta

Cholecystitis chron.

Obstructie dunne darm

Perforatie ulcus pept.

Pancreatitis

Diverticulitis

Urolithiasis

Vasculaire aandoening

Gynaccologische afw.

Maligniteit

Overige diagnoses
Gemiddelde duur begin
klacht/onderzoek EHBO

44 uur, 25 minuten

35 uur, 50 minuten

3 uur, 35 minuten

31 uur, 44 minuten

31 uor, 20 minuten

40 unur, 15 minuten

46 wur, 50 minuten

32 uur, 38 minuren

32 uur, 50 minuten

62 wur

36 uur, 40 minuten

39 uur, 40 minuten

48 uur, 20 minuten

85 uur, 6 minuten

42 uur, 55 minuten

Totaal

42 uur, 32 minuten

Bijlage 32 .

Gemiddelde cuur pre-klinische fase per categorie einddiagnose bif de geopereerden. Totale populatie. 


\begin{tabular}{|c|c|c|c|c|c|c|c|c|c|c|c|c|c|}
\hline $\begin{array}{l}\text { Einddiag- } \\
\text { nose }\end{array}$ & $\leqslant 30^{\prime}$ & $\begin{array}{l}31^{5}- \\
1 \mathrm{u}\end{array}$ & $\begin{array}{l}1- \\
2 u\end{array}$ & $\begin{array}{l}2- \\
3 u\end{array}$ & $\begin{array}{l}3- \\
4 u\end{array}$ & $\begin{array}{l}4- \\
5 \mathrm{u}\end{array}$ & $\begin{array}{l}5- \\
6 \mathrm{tu}\end{array}$ & $\begin{array}{l}\text { 6- } \\
8 u\end{array}$ & $\begin{array}{l}8- \\
12 u\end{array}$ & $\begin{array}{l}12- \\
24 \text { ut }\end{array}$ & $\begin{array}{l}24 \mathrm{u}- \\
1 w \mathrm{k}\end{array}$ & $>\| w k$ & Totan \\
\hline NSAP & - & 1 & 2 & 5 & 3 & 7 & 3 & 2 & - & 3 & 1 & 2 & 29 \\
\hline App perf: & - & 1 & 1 & 4 & 5 & 1 & 3 & 1 & 4 & 3 & - & - & 23 \\
\hline App.n.p. & 1 & 5 & 23 & 20 & 9 & 11 & 6 & 3 & 6 & 7 & 1 & - & 92 \\
\hline App.inf. & - & - & - & 1 & - & - & - & - & - & - & - & 2 & 3 \\
\hline Chol.ac. & - & - & $\Downarrow$ & 1 & 4 & 4 & 1 & 2 & 4 & 4 & 7 & 1 & 29 \\
\hline Chol, chr. & - & - & - & 2 & 1 & - & 2 & 1 & 5 & 3 & 16 & 6 & 36 \\
\hline Obs.d.d. & - & 1 & 2 & 3 & 1 & 3 & 2 & - & 3 & 3 & 4 & 2 & 24 \\
\hline Per.ulc. & - & 3 & 7 & 5 & 2 & - & $\mathbb{1}$ & - & - & 1 & - & - & 19 \\
\hline Pancrea. & - & - & - & - & - & - & $\mathbb{1}$ & - & - & - & 3 & 6. & 10 \\
\hline Divert. & - & - & - & - & - & - & $\ldots$ & 1 & - & 2 & - & $\Downarrow$ & 4 \\
\hline Urolith. & - & - & - & - & - & 1 & - & - & - & - & 1 & - & 2 \\
\hline Vase. & - & 3 & 3 & 1 & 1 & 1 & - & - & - & - & - & $\mathbb{1}$ & 10 \\
\hline Gyn. & - & - & 1 & 1 & 2 & 2 & - & - & 4 & 2 & 3 & 1 & 16 \\
\hline Malign. & - & - & 3 & 1 & 2 & - & - & 1 & - & 4 & $\mathbb{1}$ & 8 & 20 \\
\hline Overige & - & 5 & 4 & 8 & 4 & 5 & 2 & 5 & 5 & 9 & 16 & 16 & 79 \\
\hline Totaal & 1 & 19 & 47 & 52 & 34 & 35 & 21 & 16 & 31 & 41 & 53 & 46 & 396 \\
\hline
\end{tabular}

Bijlage 33.

Frequentieverdeling tase 5 in tijdseenheden per categorie einddiagnose. Totale populatie.

Eind diagnose

NSAP

Appenditicis perforata

Appenditicis non perf.

Appendiculair infiltraat

Cholecystitis acuta

Cholecystitis chron.

Obstructie dunne darm

Perforatie ulcus pept.

Pancreatitis

Diverticulitis

Urolithiasis

Vasculaire aandoening

Gynaecologische afw.

Maligniteit

Overige diagnoses
Gemiddelde duur onderzoek

EHBO/aanvang operatie

17 uur, 48 minuten

6 uur, 50 minuten

4 uur, 55 minuten

102 uur, 10 minuter.

28 uur, 25 minuten

60 uur, 55 minuten

29 uur, 50 minuten.

2 uur, 55 minuten.

113 uur, 10 minuten

48 unur, 40 minuten

33 uur, 30 minuten

16 uur, 55 minuten

29 uner

69 uur, 5 minuten

49 uur, 30 minuten

Totaal

31 uur, 42 minuten

Bijlage 34.

Gemiddelde duur fase 5 per categorie einddiagnose. Totale populatie. 


\begin{tabular}{|c|c|c|c|}
\hline $\begin{array}{l}\text { Durur pre-klinische } \\
\text { fase }\end{array}$ & $\begin{array}{l}\text { subgroep } 1 \\
\text { (ninet door huisarts } \\
\text { onderzocht) } \\
\text { Aantal }\end{array}$ & $\begin{array}{l}\text { subgroep } 2 \\
\text { (Ix of vaker door } \\
\text { huisarts onderzochr) } \\
\text { Aantal }\end{array}$ & $\begin{array}{l}\text { Total } \\
\text { Aantal }\end{array}$ \\
\hline$\leq 10^{\circ}$ & - & - & - \\
\hline $11-20^{\prime \prime}$ & - & - & - \\
\hline $21 \cdots 30^{\prime \prime}$ & 4 & - & 4 \\
\hline $31-45^{\prime}$ & - & - & - \\
\hline $46^{3}-1$ uur & 4 & - & 4 \\
\hline $1-2$ uur & 18 & - & 18 \\
\hline 2-4 uน & 28 & 2 & 30 \\
\hline 4-8 vur & 20 & 1 & 21 \\
\hline $8-12$ uut & 14 & 2 & 16 \\
\hline $12-24$ uur & 10 & 6 & 16 \\
\hline $24 u-|w| k$ & 30 & 6 & 36 \\
\hline$>1 w k$ & 11 & 4 & 15 \\
\hline Totaal & 139 & 21 & 160 \\
\hline Gemiddelde duur & $31 \mathrm{u}, 36 \min$ & $56 u, 10 \mathrm{~min}$ & $34 \mathrm{u}, 48 \mathrm{~min}$ \\
\hline
\end{tabular}

Biflage 35.

Tijdsverloop van de pre-klinische fase bij die casus welke $1 \times$ of vaker door een huisarts onderzocht werden binnen een week voor presentatie op de EHBO en tijdsverloop bij de casus die helemaal geen huisarts hadden geraadpleegd. Groep A. 


\begin{tabular}{llll}
\hline $\begin{array}{l}\text { Duur } \\
\text { pre-klinische } \\
\text { fase }\end{array}$ & $\begin{array}{l}1 \times \text { door huisarts } \\
\text { onderzocht }\end{array}$ & $\begin{array}{l}\text { Meerdere malen } \\
\text { door huisarts } \\
\text { onderzocht } \\
\text { Aantal }\end{array}$ & Totaall \\
\hline$\leqslant 10^{\prime}$ & Aantal & - & Aantal \\
$11-20^{\prime}$ & - & - & - \\
$21-30^{\prime}$ & 1 & - & 1 \\
$31-45^{\prime}$ & 7 & 1 & 7 \\
$46^{3}-1$ uur & 2 & 1 & 3 \\
$1-2$ uur & 10 & 5 & 11 \\
$2-4$ uur & 25 & 12 & 30 \\
$4-8$ uur & 47 & 23 & 59 \\
$8-12$ uur & 53 & 16 & 76 \\
$12-24$ uur & 47 & 29 & 63 \\
$24 \mathrm{u}-1$ wk & 60 & 75 & 89 \\
$>$ lwk & 106 & 19 & 181 \\
\hline Totaal & 25 & 181 & 44 \\
\hline Gemidd.duur & 383 & $51 \mathrm{u}, 10 \mathrm{~min}$ & $40 \mathrm{u}, 6 \mathrm{~min}$ \\
\hline
\end{tabular}

Bijlage 36.

Tijdsverloop van fase 1 bij die casus welke $1 \times$ onderzocht werden door de huisarts en de casus welke meerdere malen door een of meer huisartsen voor dezelfde klachten in een periode van een week wó́r verwijzing werden onderzocht. Groep E.

\begin{tabular}{|c|c|c|c|}
\hline $\begin{array}{l}\text { Duur pre- } \\
\text { klinische }\end{array}$ & $\begin{array}{l}\text { Door eigen huisarts } \\
\text { onderzocht } \\
\text { Aantal (\%) }\end{array}$ & $\begin{array}{l}\text { Tijdens waarneming } \\
\text { onderzocht } \\
\text { Aantal (\%) }\end{array}$ & $\begin{array}{l}\text { Totaal } \\
\text { Aantal }(\%)\end{array}$ \\
\hline$\leqslant 10^{3}$ & - & -- & - \\
\hline $10-20^{\prime}$ & - & $1(0,6)$ & $1(0,2)$ \\
\hline $2 \rrbracket-30^{\prime}$ & $3(10,7)$ & $4(2,6)$ & $7(1,2)$ \\
\hline $3 \rrbracket-45^{\prime}$ & $1(0,2)$ & $2(1,3)$ & $3(0,5)$ \\
\hline $46-60^{\prime}$ & $5(12,1)$ & $6(4,0)$ & $\| 1(0,2)$ \\
\hline $1-2 u$ & $13(3,1)$ & $17(11,2)$ & $30(5,3)$ \\
\hline $2-4 u$ & $38(9,2)$ & $20(13,2)$ & $58(10,2)$ \\
\hline $4-8 u$ & $51(12,3)$ & $25(16,6)$ & $76(13,5)$ \\
\hline $8-1,2 u$ & $44(10,6)$ & $20(13,2)$ & $64(11,3)$ \\
\hline $12-24 u$ & $72(17,4)$ & $17(11,3)$ & $89(15,8)$ \\
\hline $24 u-1 w k$ & $147(35,6)$ & $34(22,5)$ & $181(32,1)$ \\
\hline$>1$ week & $39(9,4)$ & $5(3,3)$ & $44(7,8)$ \\
\hline Totaal & $41.3(100)$ & $151(100)$ & $564(100)$ \\
\hline
\end{tabular}

Biilage 37.

Tijdsverloop fase 1 bij die casus welke door de eigen huisarts en tijdens de waarneming naar de EHBO verwezen werden. Groep E. 


\begin{tabular}{|c|c|c|c|}
\hline & $\begin{array}{l}\text { Ambulance } \\
\text { Aantal }(\%)\end{array}$ & $\begin{array}{l}\text { Eigen wervoer } \\
\text { Aantal }(\%)\end{array}$ & $\begin{array}{l}\text { Totaal } \\
\text { Aantal }(\%)\end{array}$ \\
\hline $10^{*}$ & - & $2(0,5)$ & $2(0,3)$ \\
\hline $11.20^{\prime}$ & $21(13,3)$ & $34(8,4)$ & $55(9,7)$ \\
\hline $2 \mathrm{~L}-30^{\prime}$ & $25(15,8)$ & $50(12,3)$ & $75(13,3)$ \\
\hline $31.45^{\prime}$ & $19(12,0)$ & $61(15,0)$ & $80(14,1)$ \\
\hline $466-60^{4}$ & $39(24,7)$ & $82(20,2)$ & $121(21,4)$ \\
\hline 1-2ure & $40(25,3)$ & $124(30,5)$ & $164(29,1)$ \\
\hline $2-4$ uur & $11(7,0)$ & $37(9,1)$ & $48(8,5)$ \\
\hline 4-8 ubur & $3(1,9)$ & $10(2,5)$ & $13(2,3)$ \\
\hline $8-12$ uur & $-\infty$ & $4(1,0)$ & $4(0,7)$ \\
\hline 12.24 wur & -- & $1(0,2)$ & $1(0,2)$ \\
\hline $24 \mathrm{u}-\| w \mathrm{k}$ & $-\quad-$ & $1(0,2)$ & $1(0,2)$ \\
\hline$>1$ week & - & - & - \\
\hline Totaral! & $158(100)$ & $406(100)$ & $564(100)$ \\
\hline
\end{tabular}

Bijlage 38.

Tijdsverloop fase 3 bij cigen vervoer en bij ambulancevervoer. Groep $\mathrm{E}$.

\begin{tabular}{|c|c|c|c|c|}
\hline Einddiagnose & NSAP & App.non perf. & Overige & Total aantal \\
\hline$\leqslant 10^{\prime}$ & - & - & - & - \\
\hline $11-20^{\prime}$ & - & - & - & - \\
\hline $21-30^{\prime}$ & - & - & - & - \\
\hline $31-45$ & - & - & - & - \\
\hline $46-60^{x}$ & - & - & - & - \\
\hline $1 \cdot 2 u u r$ & - & - & - & - \\
\hline $2 \cdot 4$ uar & 1 & - & 1 & 2 \\
\hline $4-8$ usur & 1 & - & - & 1 \\
\hline 8-12 unat & 1 & - & 1 & 2 \\
\hline $12-24$ uur & 4 & 2 & - & 6 \\
\hline 24 uur- I wk & 4 & - & $2^{\star}$ & 6 \\
\hline$>1$ wk & 3 & - & $1^{\star \star}$ & 4. \\
\hline Totaal & 14 & 2 & 5 & 21 \\
\hline
\end{tabular}

Bijiage 39.

Tijdsverloop pre-klinische fase bij die casus welke in een periode minder dan een week voor binnenkomst EHBO door een of meerdere huisartsen een of meer malen voor dezelfde klachten werden onderzocht. Groep A.

* coprostasis, hernia inguinalis

* torsio testis 
Einddiagnose

NSAP

Appendicitis non perf.

Overige
Gemiddelde dur begin klach/binneakomst EHBO

59 uur, 40 minuten

18 uur

61 uur, 50 minuten

Toraal

56 uur, 10 minuten

Bịlage 40 .

Gemiddeld tijdsverloop van de pre-klinische fase bij diegenen die een of meer keren door cen of meer huisartsen voor dezelfde klacht binnen een week voor presentatie op de EHBO onderzocht werden. Groep A.

\begin{tabular}{|c|c|c|c|c|c|c|c|c|c|c|c|c|c|}
\hline $\begin{array}{l}\text { Eind- } \\
\text { diagnose }\end{array}$ & $\leqslant 10^{3}$ & $\begin{array}{l}11- \\
20\end{array}$ & $\begin{array}{l}21- \\
30^{\circ}\end{array}$ & $\begin{array}{l}31- \\
45^{\prime}\end{array}$ & $\begin{array}{l}46- \\
60^{\prime \prime}\end{array}$ & $\begin{array}{l}1- \\
2 \text { u }\end{array}$ & $\begin{array}{l}2- \\
4 u\end{array}$ & $\begin{array}{l}4- \\
8 u\end{array}$ & $\begin{array}{l}8- \\
12 \mathrm{n}\end{array}$ & $\begin{array}{l}12- \\
24 \mathrm{u}\end{array}$ & $\begin{array}{l}24- \\
1 w k\end{array}$ & $>1 w k$ & $\begin{array}{l}\text { Totaal } \\
\text { antal }\end{array}$ \\
\hline NSAP & - & - & - & 2 & 3 & 19 & 24 & 31 & 22 & 34 & 62 & 18 & 215 \\
\hline App.perf. & - & - & $\mathbb{1}$ & - & - & 2 & - & 4 & - & 6 & 6 & 1 & 20 \\
\hline App.n.p. & - & - & - & - & - & - & 6 & 12 & 13 & 16 & 12 & 1 & 60 \\
\hline App.inf. & - & - & - & - & - & - & 1 & 2 & 1 & 3 & 10 & 2 & 19 \\
\hline Chol.ac. & - & - & - & - & - & - & 4 & 1 & 4 & 1 & 6 & - & 16 \\
\hline Chol.chr. & - & - & - & - & 1 & 3 & 2 & 3 & 1 & 3 & 6 & - & 19 \\
\hline Ob.d.d. & - & - & 1 & 1 & - & - & 6 & 2 & 1 & 1 & 9 & - & 21 \\
\hline Gep.ulc. & - & - & - & - & 1 & 1 & 5 & 1 & 6 & 1 & 4 & - & 19 \\
\hline Panct. & - & - & 2 & - & 1 & - & 2 & 6 & - & 4 & 12 & - & 27 \\
\hline Divert. & - & - & - & - & - & - & - & 1 & 2 & 1 & 3 & 1 & 8 \\
\hline Urolith. & - & - & - & - & 1 & - & 2 & - & - & 2 & - & - & 5 \\
\hline Vasc.afw. & - & 1 & $\mathbb{1}$ & - & 2 & - & 2 & 2 & - & - & 1 & 1 & 10 \\
\hline Gyn.afw. & - & - & - & - & 1 & - & - & 1 & 2 & 1 & 5 & - & 10 \\
\hline Mallign. & - & - & - & - & - & - & - & 1 & 2 & - & 4 & 6 & 13 \\
\hline Overige & - & - & 2 & - & 1 & 5 & 5 & 9 & 9 & 16 & 41 & 14 & 102 \\
\hline Totaal & - & 1 & 7 & 3 & 11 & 30 & 59 & 76 & 63 & 89 & 182 & 43 & 564 \\
\hline
\end{tabular}

Bujlage 41 .

Frequentieverdeling fase 1 per tijdseenheid per categorie einddiagnose. Groep E.

\begin{tabular}{|c|c|c|c|c|c|c|c|c|c|c|c|c|c|}
\hline $\begin{array}{l}\text { Eind- } \\
\text { diagnose }\end{array}$ & $\leq 10^{x}$ & $\begin{array}{l}11- \\
20\end{array}$ & $\begin{array}{l}21= \\
30^{\prime}\end{array}$ & $\begin{array}{l}31 . \\
45\end{array}$ & $\begin{array}{l}45 \\
60^{\circ}\end{array}$ & $\begin{array}{l}1- \\
2 \mathrm{u}\end{array}$ & $\begin{array}{l}2 * \\
4 u\end{array}$ & $\begin{array}{l}4- \\
8 \amalg\end{array}$ & $\begin{array}{l}8 . \\
12 u\end{array}$ & $\begin{array}{l}12 \\
24 \text { แ }\end{array}$ & $\begin{array}{l}24 . \\
1 w k\end{array}$ & $>$ lwk & $\begin{array}{l}\text { Totmal } \\
\text { aantal }\end{array}$ \\
\hline NSAP & 101 & 43 & 21 & 2 & 8 & 21 & 13 & 5 & 1 & - & - & - & 21.5 \\
\hline App perf. & 4 & 7 & 3 & - & 2 & 3 & 1 & - & - & - & - & - & 20 \\
\hline App.n.p. & 14 & 6 & 10 & 5 & 4 & 7 & 11 & 3 & - & 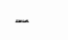 & - & - & 60 \\
\hline App.inf. & 6 & 3 & 1 & 2 & 1 & - & 4 & 2 & - & - & - & $\cdots$ & 19 \\
\hline Totanal & 125 & 59 & 35 & 9 & 15 & 31 & 29 & 10 & 1 & - & - & - & 314 \\
\hline
\end{tabular}

Bijlage 42 .

Frequentieverdeling fase 2 per rijdseenheid voor de einddiagnoses NSAP en appendicitis. Groep E. 


\begin{tabular}{|c|c|c|c|c|c|c|c|c|c|c|c|c|c|}
\hline $\begin{array}{l}\text { Eind- } \\
\text { diagnose }\end{array}$ & $10^{\prime}$ & $\begin{array}{l}11 \\
20^{\circ}\end{array}$ & $\begin{array}{l}21- \\
30^{5}\end{array}$ & $\begin{array}{l}31 \\
45\end{array}$ & $\begin{array}{l}46 \% \\
60^{\prime \prime}\end{array}$ & $\begin{array}{l}1 . \\
2 u\end{array}$ & $\begin{array}{l}2 \\
4 w\end{array}$ & 8 & $\begin{array}{l}8- \\
12 !\end{array}$ & $\begin{array}{l}12 \\
24 \mathrm{u}\end{array}$ & $\begin{array}{l}24- \\
1 \mathrm{wk}\end{array}$ & $>l w k$ & $\begin{array}{l}\text { Totaal } \\
\text { aantal }\end{array}$ \\
\hline NSAP & - & 18 & 32 & 25 & 56 & 59 & 15 & 6 & 3 & 1 & - & - & 215 \\
\hline App perf. & - & 1 & 1 & 5 & 4 & 6 & 2 & 1 & - & - & - & - & 20 \\
\hline App.n.p. & - & 4 & 1 & 14 & 9 & 26 & 5 & 1 & - & - & - & - & 60 \\
\hline App.inf & - & 3 & 3 & 3 & $\mathbb{1}$ & 4 & 5 & - & - & - & - & - & 19 \\
\hline Totaal & - & 26 & 37 & 47 & 70 & 95 & 27 & 8 & 3 & 1 & - & - & 314 \\
\hline
\end{tabular}

Bijlage 43.

Frequentieverdeling fase 3 per tijdseenheid voor de einddiagnoses NSAP en appendicitis. Groep E.

\begin{tabular}{|c|c|c|c|c|c|c|c|c|c|c|c|c|c|}
\hline $\begin{array}{l}\text { Eind- } \\
\text { diagnose }\end{array}$ & $\leqslant 30^{3}$ & $\begin{array}{l}3 \|^{\prime}- \\
1 u\end{array}$ & $\begin{array}{l}1- \\
2 \mathrm{u}\end{array}$ & $\begin{array}{l}2- \\
3 u\end{array}$ & $\begin{array}{l}3- \\
411\end{array}$ & $\begin{array}{l}4- \\
5 u\end{array}$ & $\begin{array}{l}5 . \\
64\end{array}$ & $\begin{array}{l}6= \\
8 u\end{array}$ & $\begin{array}{l}8 . \\
12 u\end{array}$ & $\begin{array}{l}12 \\
24 \mathrm{u}\end{array}$ & $\begin{array}{l}24- \\
1 \mathrm{wk}\end{array}$ & $>$ lwk & $\begin{array}{l}\text { Totaal } \\
\text { aantal }\end{array}$ \\
\hline NSAP & - & 1 & 2 & 1 & 2 & 7 & 1 & 1 & - & 2 & 1 & 1 & 19 \\
\hline App.penf. & - & 1 & 1 & 3 & 4 & 1 & 3 & 1 & 3 & 3 & - & - & 20 \\
\hline App.n.p. & 1 & 4 & 20 & 14 & 4 & 7 & 4 & 1 & 1 & 4 & - & - & 60 \\
\hline Appint. & - & - & - & - & - & - & - & - & - & - & - & 2 & 2 \\
\hline Totaal & 1 & 6 & 23 & 18 & 10 & 15 & 8 & 3 & 4 & 9 & 1 & 3 & 101 \\
\hline
\end{tabular}

Bijlage 44.

Frequentieverdeling fase 5 per tijdseenheid voor de einddiagnoses NSAP an appendicitis. Groep E.

Einddagnose Non Specific

Aantal

Abdominal Pain

\begin{tabular}{lr}
\hline Appendix sana & 20 \\
Dyspepsie & 3 \\
Gasitritits & 2 \\
Entteritis & 3 \\
Lymfadenitis mesenterialis & 2 \\
Opstipatie/coprostasis & 2 \\
Geenenkele diagnose & 437
\end{tabular}

Totaal

469

Bijlage 45.

Werkelijk gestelde einddiagnoses onder de noemer Non Specific Abdominal Pain. 


\begin{tabular}{lcccc}
\hline Einddiagnose & $\begin{array}{l}\text { NSAP } \\
\text { Aantal }(\%)\end{array}$ & $\begin{array}{l}\text { App.perforata } \\
\text { Aantal }(\%)\end{array}$ & $\begin{array}{c}\text { App.non perf. } \\
\text { Aantal }(\%)\end{array}$ & $\begin{array}{l}\text { App.infiltrat } \\
\text { Aantal }(\%)\end{array}$ \\
\hline$\leqslant 1$ uur & $5(2,3)$ & $1(5,0)$ & -- & - \\
$1-2$ uur & $19(8,8)$ & $2(10,0)$ & -- & - \\
$2-4$ uur & $24(11,1)$ & -- & $6(10,0)$ & $1(5,2)$ \\
$4-8$ uur & $31(14,4)$ & $4(20,0)$ & $12(20,0)$ & $2(10,4)$ \\
$8-12$ uur & $22(10,2)$ & -- & $13(21,6)$ & $1(5,2)$ \\
$12-24$ uur & $34(15,8)$ & $6(30,0)$ & $16(26,2)$ & $3(15,7)$ \\
24 uur-1 wk & $62(28,8)$ & $6(30,0)$ & $12(20,0)$ & $10(52,6)$ \\
$>1$ wk & $18(8,3)$ & $1(5,0)$ & $1(1,6)$ & $2(10,4)$ \\
\hline Totaal & $215(100 \%)$ & $20(100 \%)$ & $60(100 \%)$ & $19(100 \%)$ \\
\hline
\end{tabular}

Bijlage 46.

Totstandkoming van de gemiddelde duur van de fasen 1 bij de categorieèn einddiagnoses NSAP, app perf., app non perf. en app. infiltraat. Groep E. 

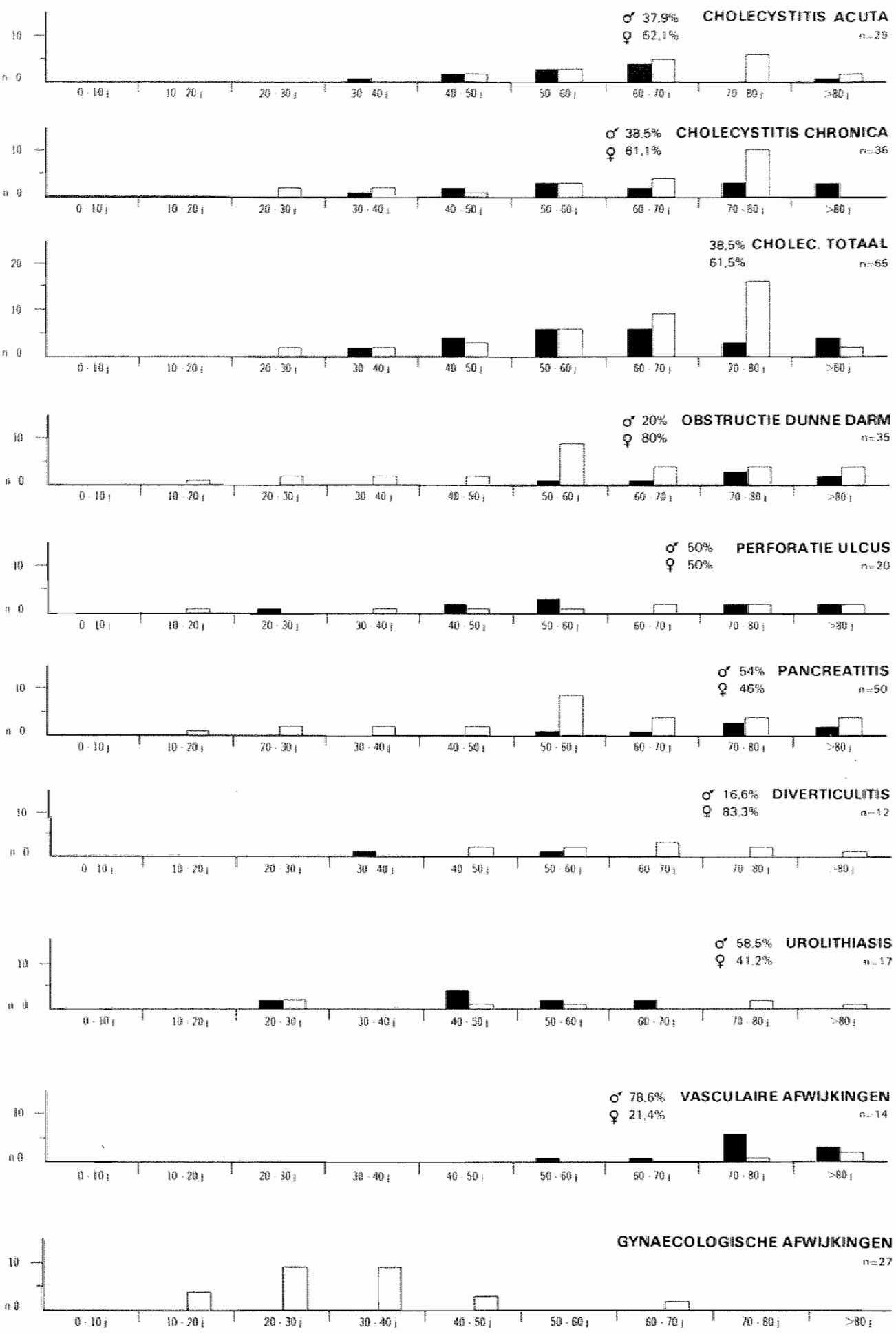

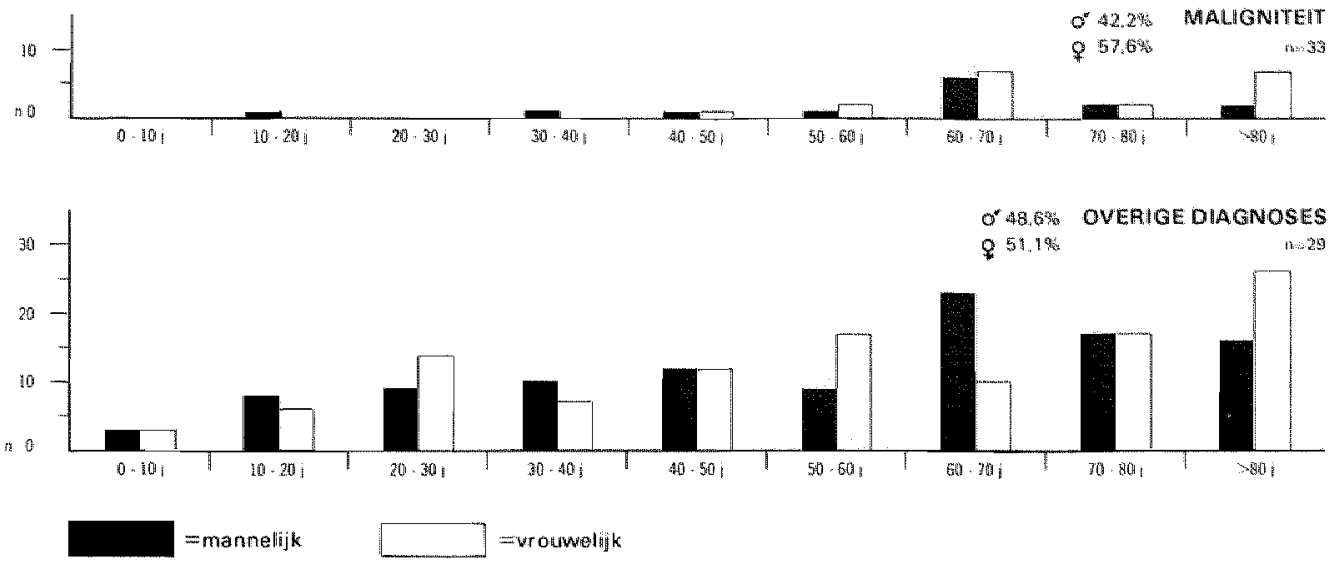

Bijlage 47.

Leeftijds- en geslachtsopbouw van alle categorieën einddiagnoses, behalve NSAP en appendicitis.

Totale populatie.

\begin{tabular}{|c|c|c|c|c|c|}
\hline \multicolumn{2}{|c|}{ Leeftijd } & $\begin{array}{l}\text { NSAP } \\
\text { Aantal } \%\end{array}$ & $\begin{array}{l}\text { Appendicitis } \\
\text { Aantal } \%\end{array}$ & $\begin{array}{l}\text { Overige diagn. } \\
\text { Aantal } \%\end{array}$ & $\begin{array}{l}\text { Totaal } \\
\text { Aantal }(100 \%)\end{array}$ \\
\hline \multirow[t]{2}{*}{$0.10 j$} & $M$ & $19(76)$ & $3(12)$ & $3(12)$ & 25 \\
\hline & $\mathrm{V}$ & $15(75)$ & $2(10)$ & $3(15)$ & 20 \\
\hline \multirow[t]{2}{*}{$10-20 j$} & $M$ & $45(54,8)$ & $28(34,1)$ & $9(11,1)$ & 82 \\
\hline & V & $75(67,6)$ & $23(20,7)$ & $13(11,7)$ & 111 \\
\hline \multirow[t]{2}{*}{$20-30 i$} & $M$ & $62(67,4)$ & $17(18,4)$ & $13(14,1)$ & 92 \\
\hline & V & $68(58,1)$ & $19(16,2)$ & $30(25,6)$ & 117 \\
\hline \multirow[t]{2}{*}{$30-40 j$} & $M$ & $2.1(38,9)$ & $14(25,9)$ & $19(35,2)$ & 54 \\
\hline & V & $38(55,9)$ & $3(4,4)$ & $27(39,7)$ & 68 \\
\hline \multirow[t]{2}{*}{$40-50 \mathrm{j}$} & $M$ & $26(40,6)$ & $7(10,9)$ & $31(48,4)$ & 64 \\
\hline & V & $22(40)$ & $5(9,1)$ & $28(50,9)$ & 55 \\
\hline \multirow[t]{2}{*}{$50-60 j$} & M & $19(35,8)$ & $5(9,4)$ & $29(54,7)$ & 53 \\
\hline & $\mathrm{V}$ & $15(24,6)$ & $3(4,9)$ & $43(70,5)$ & 61 \\
\hline \multirow[t]{2}{*}{$60-70 j$} & $M$ & $9(17,3)$ & $1(1,9)$ & $42(80,8)$ & 52 \\
\hline & $\mathrm{V}$ & $10(20,4)$ & $1(2)$ & $38(77,6)$ & 49 \\
\hline \multirow[t]{2}{*}{$70-80 i$} & $M$ & $7(14,6)$ & $4(8,3)$ & $37(77,1)$ & 48 \\
\hline & $\mathrm{V}$ & $8(13,5)$ & $3(5,1)$ & $48(81,3)$ & 59 \\
\hline \multirow[t]{2}{*}{$>80 j$} & M & $6(15,8)$ & $0-$ & $32(84,2)$ & 38 \\
\hline & V & $4(7,7)$ & $\mathbb{I}(1,9)$ & $47(90,4)$ & 52 \\
\hline \multirow[t]{2}{*}{ Totaal } & $M$ & $214(42,1)$ & $79(15,6)$ & $215(42,3)$ & 508 \\
\hline & V & $255(43,1)$ & $60(10,1)$ & $277(46,8)$ & 592 \\
\hline
\end{tabular}

Bijlage 48 .

Frequentieverdeling NSAP, appendicitis acuta en de overige diagnoses naar teeftijd en geslacht.

Totale populatie. 


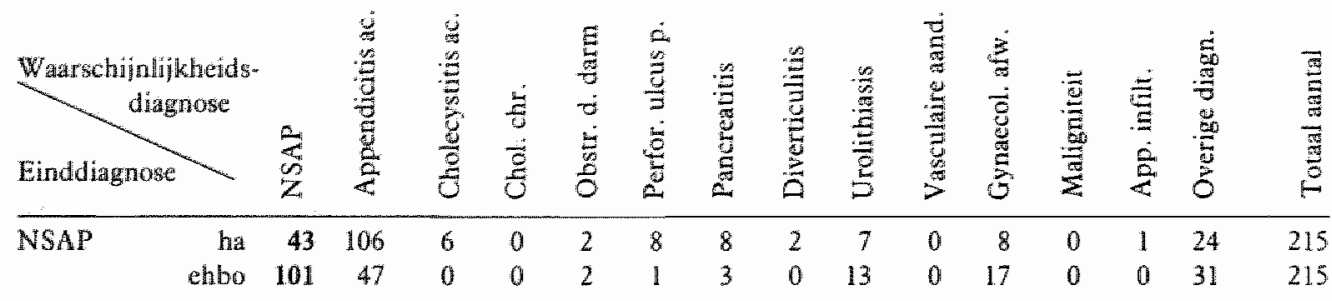

$\begin{array}{lllllllllllllllll}\text { Appendicitis ha } & 5 & 73 & 0 & 0 & 0 & 0 & 0 & 0 & 0 & 0 & 1 & 0 & 0 & 1 & 80\end{array}$
$\begin{array}{llllllllllllllll}\text { acuta chbo } & 3 & 74 & 0 & 0 & 0 & 0 & 0 & 0 & 0 & 0 & 1 & 0 & 0 & 2 & 80\end{array}$

$\begin{array}{lllllllllllllllll}\text { Cholecystitis } & \text { ha } & 1 & 1 & 9 & 0 & 0 & 0 & 3 & 0 & 0 & 1 & 0 & 0 & 0 & 1 & 16\end{array}$

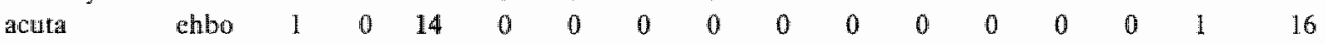

\begin{tabular}{lllllllllllllllll}
\hline Cholecystitis & ha & 0 & 2 & 0 & 17 & 0 & 0 & 0 & 0 & 0 & 0 & 0 & 0 & 0 & 0 & 19
\end{tabular}

chr. ehbo $0 \begin{array}{lllllllllllllll} & 0 & 0 & 19 & 0 & 0 & 0 & 0 & 0 & 0 & 0 & 0 & 0 & 0 & 19\end{array}$

\begin{tabular}{lllllllllllllllll}
\hline Obstructie ha & 1 & 1 & 1 & j. & 10 & 1 & 0 & 1 & 0 & 1 & 0 & 0 & 0 & 4 & 21
\end{tabular}

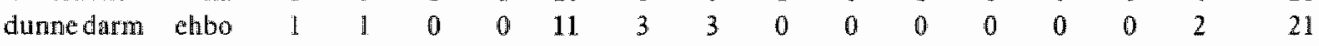

\begin{tabular}{lllllllllllllllll}
\hline Perforatic ha & 0 & 2 & 0 & 0 & 3 & 14 & 0 & 0 & 0 & 0 & 0 & 0 & 0 & 0 & 19
\end{tabular}

ulcuspept. elhbo $0 \begin{array}{lllllllllllllll} & 0 & 0 & 0 & 0 & 18 & 0 & 0 & 0 & 0 & 0 & 0 & 0 & 1 & 19\end{array}$

\begin{tabular}{lllllllllllllllll}
\hline Pancreatitis ha & 1 & 1 & 6 & 0 & 0 & 5 & 13 & 0 & 0 & 0 & 0 & 0 & 0 & 1 & 27
\end{tabular} $\begin{array}{llllllllllllllll}\text { elabo } & 0 & 0 & 0 & 1 & 0 & 3 & 23 & 0 & 0 & 0 & 0 & 0 & 0 & 0 & 27\end{array}$

\begin{tabular}{rlllllllllllllll}
\hline Diverticulitis ha & 0 & 1 & 1 & 0 & 0 & 0 & 1 & 2 & 0 & 0 & 0 & 0 & 0 & 3 & 8 \\
elabo & 0 & 0 & 0 & 0 & 0 & 0 & 0 & 5 & 0 & 0 & 0 & 0 & 0 & 3 & 8
\end{tabular}

\begin{tabular}{lllllllllllllllll}
\hline Urolithiasis tha & 0 & 0 & 0 & 0 & 0 & 0 & 0 & 0 & 4 & 0 & 0 & 0 & 0 & 1 & & 5
\end{tabular}

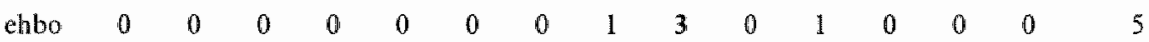

\begin{tabular}{lllllllllllllllll}
\hline Vasculaire tha & 0 & 1 & 0 & 0 & 0 & 0 & 1 & 0 & 0 & 7 & 0 & 0 & 0 & 1 & 10
\end{tabular}

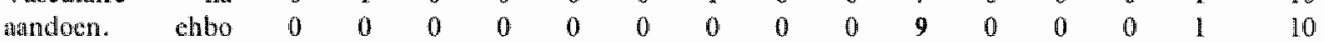

\begin{tabular}{llllllllllllllll}
\hline Gynaccolo- ha & 0 & 5 & 0 & 0 & 0 & 0 & 0 & 0 & 1 & 0 & 3 & 0 & 0 & 1 & 10
\end{tabular}

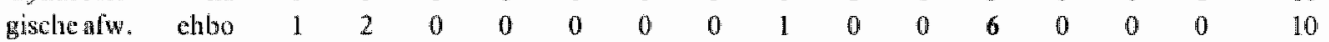

\begin{tabular}{lllllllllllllllll}
\hline Maligniteit ha & 2 & 0 & 1 & 0 & 0 & 0 & 0 & 1 & 1 & 0 & 0 & 1 & 0 & 7 & 13
\end{tabular}

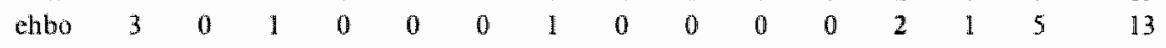

\begin{tabular}{lllllllllllllllll}
\hline Appendicu- ha & 1 & 9 & 0 & 0 & 0 & 0 & 0 & 1 & 0 & 0 & 0 & 0 & 8 & 0 & 19
\end{tabular}

$\begin{array}{llllllllllllllll}\text { lair infilt. elhbo } & 1 & 4 & 0 & 0 & 0 & 0 & 0 & 0 & 0 & 0 & 0 & 0 & 14 & 0 & 19\end{array}$

\begin{tabular}{lrrrrrrrrrrrrrrrrr}
\hline $\begin{array}{l}\text { Overige } \\
\text { diagnoses }\end{array}$ & $\begin{array}{rrrrrrrrr}6 \\
\text { chbo }\end{array}$ & 3 & 10 & 2 & 1 & 1 & 1 & 0 & 2 & 2 & 1 & 1 & 3 & 0 & $56 / 19 *$ & 102 \\
\hline Totaal & ha & 60 & 214 & 25 & 20 & 16 & 32 & 29 & 10 & 13 & 9 & 13 & 4 & 13 & 106 & 564 \\
aantal & ehbo & 114 & 138 & 17 & 21 & 14 & 26 & 30 & 9 & 18 & 10 & 26 & 5 & 15 & 121 & 564.
\end{tabular}

Bijlage 49 .

Warschijnlijkheidsdiagnose huisarts en EHBO versus einddiagnoses (Groep E).

* onjuiste werkelijke diagnose. 


\section{DANKWOORD}

Promoveren is naast het voeren van een huisartsenpraktijk een nauwelijks te volbrengen taak. Elke huisarts en eenieder die in zijn direkte nabijheid verblijft zal dit kunnen beamen. Dat mijn proefschrift desondanks toch tot stand kwam is te danken aan de inspiratie en stimulatie door velen.

Hooggeleerde Brouwer, beste Wim, mijn dank voor de vele uren die je aan mij hebt besteed. Je was een zeer kritisch, maar vooral een geduldig promotor. Door je scherpe opmerkingsvermogen heb je me langs talloze valkuilen geloodsd en me veel laten ontdekken en leren.

Hooggeleerde Greep, beste Co. Door jou ben ik gaan inzien hoe je een onderzoek organiseert en een proefschrift opzet. Je inzicht, je vermogen om ideeën te ontwikkelen tot haalbare praktijk en je ter zake kundigheid, met name op huisartsgeneeskundig terrein, hebben me met bewondering vervuld. Het was mij een eer dat je promotor wilde zijn. Zeergeleerde Van den Hoogenband, beste Cees-Rein, jij bent degene geweest die mij op het juiste been zette om dit onderzoek te gaan doen. Van meet af aan heb je meegedacht, kritische kanttekeningen geplaatst en me geinspireerd door je sprankelende vitaliteit. Je hebt me geïntroduceerd in de kliniek en geholpen waar en wanneer dat nodig was. Zonder jou zou dit proefschrift nooit tot stand zijn gekomen.

Geleerde Leffers, beste Pieter. Ook jij bent een steun en toeverlaat geweest van het eerste uur. Je logisch redeneren en je bijdragen als epidemioloog zijn van grote waarde geweest. Hiervoor mijn oprechte dank.

Beste Marres, als hoofd van de medische administratie van het Academisch Ziekenhuis ben je van belang geweest bij het ontwikkelen van de onderzoeksformulieren en voor de logistieke steun. Mijn dank hiervoor.

Waarde Voskamp, beste Chris. Voor de begaafde wijze waarop je een bijdrage hebt geleverd aan de lay-out ben je van harte bedankt.

Beste Mevrouw Piets, U hebt de samenvatting op deskundige wijze vertaald in het Engels. Mijn hartelijke dank voor Uw inzet.

Beste Mevrouw Oostveen, beste Els. Bedankt voor de onvermoeibare en accurate wijze waarop je het type-werk hebt gedaan.

Geleerde Smits, beste Frank. Vaak heb je voor mij waargenomen waardoor ik in de gelegenheid werd gesteld om ongestoord te werken. Hiervoor mijn oprechte dank. Waarde collega-huisartsen. Vrijwel unaniem hebben jullie aan de Acute Buik Analyse geparticipeerd. Zonder enige contra-prestatie. Jullie hebt aangetoond dat groot opgezet onderzoek in de le lijn praktisch uitvoerbaar is. Mijn dank hiervoor.

Geleerde Vergroesen, beste Ruud. Aan jou ben ik speciale dank verschuldigd. Als huisarts-opleider heb jij mij de dagelijkse praktijk, het échte vak, geleerd. Jouw voorbeeld staat mij nog steeds voor ogen.

Lieve Marianne, Willem, Dorine en Anne-Marie. Als echtgenoot en vader hebben jullie mij vaak moeten missen. Ik kan jullie dan ook niet genoeg danken voor de solidariteit die jullie konden opbrengen en voor het gedurende al die jaren in mij gestelde vertrouwen. Beste ouders, het laatste woord is voor $\mathrm{U}$ beiden. Bedankt voor het goede voorbeeld en voor alle inspanningen die $\mathrm{U}$ zich jarenlang voor mij hebt moeten getroosten. $\mathrm{U}$ hebt de basis gelegd voor mijn carrière. 


\section{CURRICULUM VITAE}

De schrijver van dit proefschrift werd geboren te Tilburg op 18 april 1946. Op 12 juli 1963. behaalde hij aan de St. Petrus MULO te Gilze het diploma MULO A. Op 3 juni 1966 slaagde hij woor zijn examen HBS B aan de John F. Kennedy HBS te Dongen. In dat zelfde jaar begon hij zijn studie Medicijnen aan de Rijksuniversiteit te Utrecht alwaar hij op 26 oktober 1973 werd beëdigd tot arts.

Zijn opleiding tot huisarts volgde hij bij de Philips Medische Dienst te Eindhoven (opleider: drs. R.J. Vergroesen). Op 30 januari 1975 werd hij ingeschreven in het Register van Erkende Huisartsen.

Van 6 januari 1975 tot 1 maart 1976 vervulde hij zijn militaire dienstplicht als onderdeelsarts van het Pantser Infanterie Rij- en Opleidingscentrum (PIROC) te Veldhoven. Onmiddellijk hierna vestigde hij zich als huisarts in Maastricht als opvolger van drs. A.M.M. America. 